Heverson Akira Tamashiro

\title{
Desenho técnico arquitetônico: constataşão do atual ensino nas escolas brasileiras de arquitetura e urbanismo
}

Dissertação apresentada à Escola de Engenharia de São Carlos da Universidade de São Paulo, como parte integrante dos requisitos para a obtencão do Título de Mestre em Arquitetura e Urbanismo

Orientador Profa. Dra. Maria Angela Pereira de Castro e Silva Bortolucci 


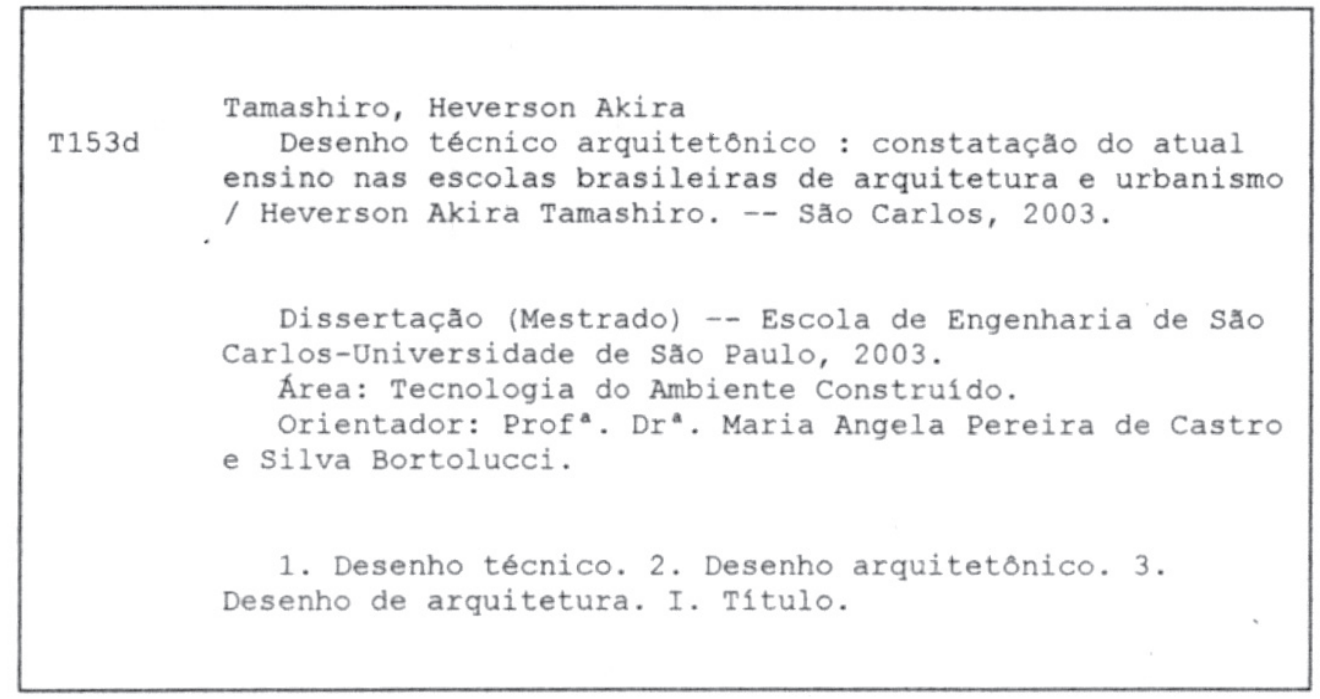




\section{FOLHA DE JULGAMENTO}

\section{Candidato Arquiteto HEVERSON AKIRA TAMASHIRO}

Dissertação defendida e julgada em 10-09-2003 perante a Comissão Julgadora

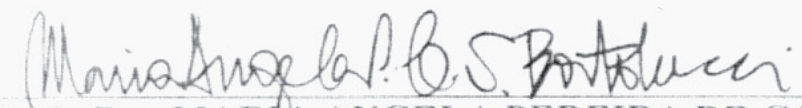

da Dra MARPA ANGELA PEREIRA DE CASTRO E SILVA

APROVADO

BORTOLUCCI (Orientadora)

(Escola de Engenharia de São Carlos/USP)

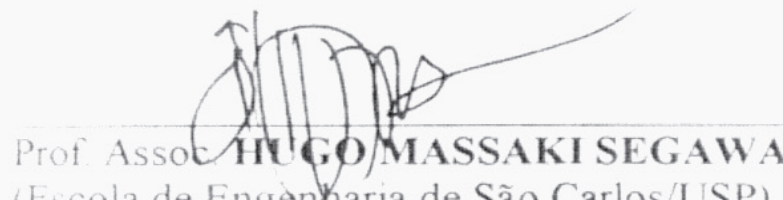

(Escola de Engentharia de São Carlos/USP)

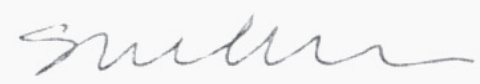

Profa. Dra. SARAH FELDMAN

Coordenadora do Programa de Pós-Graduação em Arquitetura e Urbanismo

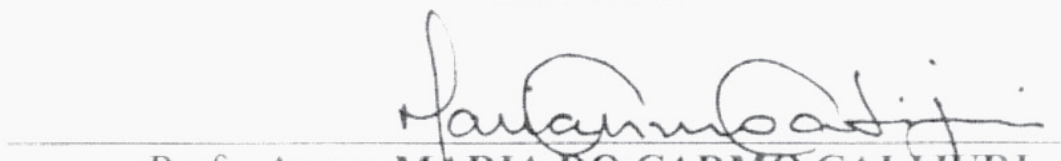

Profa. Assoc MARIA DO CARMO CALNURI

Presidente da Comissão de Pós-Graduação da EESC 

à Maria 



\section{Agradecimentos:}

a Eurico Ugaya e João Bezerra de Menezes, de quem surgiram as primeiras idéias deste trabalho / ao Carlos Martins, pelas primeiras orientações / a todos os colegas professores do SAP EESC, em especial ao Givaldo Medeiros, David Sperling, Cibele Rizek, Mancha, João Marcos, Akemi, Renato Anelli, Manoel, Rosana, Márcio / a Hugo Segawa, Admir Basso, Roti Turin e Marcelo Suzuki, pelas conversas e apoio / a Jairo Sales, José Mário, Luiz Gastão, Ricardo Schaal / a Cynthia Aleixo, Nilton Nardelli, Karina Delarisse, Paulo de Camargo, Melissa Matsunaga, Patrícia Junqueira, Maria Lúcia, Adriana Fonseca, Marina Barros, Tatiana Sakurai, Emerson Faria, Paula Russo, Camila Frederico, Marcele Silveira, Letícia Barreto, Luciana Mascaro, Maristela Gava, Naguissa Yuba, Giselle Pinna / a Maria Alice Venturini e Nídia Kuri / a todos os professores que participaram do questionário / ao Gogliardo Maragno / às 

Por mais redundante que possa ser, não custa lembrar que as verdades científicas são verdades humanas e não divinas, isto é, são aproximações sucessivas em relação à realidade, necessariamente precárias, e sujeitas obrigatoriamente à sua fatal reconsideração. Isto é, cada verdade científica é somente uma descrição mais precisa da realidade em relação à anterior.

JULIO ROBERTO KATINSKY in SANTILLANA, 1981, p.7 

Trata-se da constatação de que o ensino de desenho arquitetônico, nas escolas brasileiras de arquitetura, apresenta um quadro pouco positivo, em que os alunos não utilizam adequadamente a representação gráfica do desenho técnico arquitetônico na criação e na produção do objeto de arquitetura. Fica evidente o pouco domínio dessa ferramenta básica, necessária ao exercício da profissão de arquiteto, o que compromete seu bom desempenho. 0 trabalho se dá a partir da fundamentação teórica sobre a matéria, seguindo-se com a elaboração e aplicação de um questionário a professores de desenho arquitetônico e de CAD, o levantamento e análise de manuais ainda em uso por professores e alunos e, por fim, entrevistas com arquitetos e/ou professores. Os resultados nos instigam à auto-reflexão e à revisão de algumas posturas, a fim de contribuir para a qualidade do ensino de arquitetura e urbanismo e, conseqüentemente, para uma melhor capacitação profissional do arquiteto.

Palavras-chave: Desenho técnico; Desenho arquitetônico; Desenho de arquitetura.

\section{Abstract}

This work analyses the teaching of architectural drawing at Brazilian schools of architecture, coming to a general picture which is not a good one, for the students do not use correctly the graphic representation of the architectural technical drawing, when creating or producing the object of architecture. Such lack of knowledge for using this basic tool, which is so necessary to the architects, endangers their professional performance. The works presents a theoretical foundation on architectural drawing; a questionary apllied to the teachers of architectural drawing and CAD; a list and analysis of manuals in use by teacher and stundents; and, eventually, interviews with architects and/or teachers. The results instigate us to reconsider our role and to review our positions, in order to contribute to the improvement of the quality of the architecture and urbanism teaching and, as a consequence, to a better professional performance of the architects.

Key-words: Technical drawing; Architectural drawing; Architecture design. 

[1] Desenho de arquitetura, 25

Aproximações do conceito e finalidade, 35

Alguns tipos de desenhos de arquitetura, 36

O desenho como comunicação, 48

O CAD e o desenho técnico arquitetônico, 52

\section{[2] Constatação do atual ensino de desenho arquitetônico, 59 \\ Números desafiantes, 60 \\ O desenho arquitetônico, sem "Desenho Arquitetônico", 63 \\ A crise do "não-desenho", 64}

[3] Análise do questionário, 83

Bloco A: As escolas que participaram, 84

Bloco B: Perfil das escolas e dos professores, 86 Bloco C: Disciplina principal e complementares, 87 Bloco D: Recursos, 92

Bloco E: Metodologia, 96

Bloco F: Os desenhos e o canteiro de obras, 103 Bloco G: Sobre o CAD, 105 Bloco H: Finalmente ..., 111

\section{[4] Análise dos manuais de desenho arquitetônico, 121 Desenho arquitetônico, de Lamartine Oberg, 124 Desenho arquitetônico, de Gildo Montenegro, 136 Os manuais do Ching, 144 Norma ABNT NBR-6492, 162}

Considerações finais, 169

\section{Referências, 181 Lista das ilustrações, 187}

\footnotetext{
Apêndices, 191

[A] Planilha de levantamento das escolas de arquitetura, 195

[B] Questionário, 199

[C] Planilha de respostas do questionário, 209 [D] Lista dos livros/manuais de desenho arquitetônico, 219

[E] Entrevistas, 227
}

Anexos, 263

[A] Norma ABNT NBR 6492, 265 


\section{Introdução}

Este trabalho surgiu, inicialmente, da idéia de analisar a cotagem em desenho arquitetônico a partir dos manuais técnicos disponibilizados no Brasil desde 1930, verificando sua validade, atualidade e contribuição efetiva para o ensino nas escolas/faculdades de arquitetura e urbanismo. Também se pretendia, ainda, propor subsídios para elaboração de um novo manual, mais atualizado, incluindo as questões pertinentes ao desenho informatizado. No entanto, no decorrer da pesquisa - catalogação e análise dos manuais, elaboração e aplicação de um questionário eletrônico a professores de desenho arquitetônico e de CAD das principais escolas de arquitetura do Brasil e, por fim, entrevista com alguns arquitetos e/ou professores -, o trabalho caminhou, em função e a partir desta metodologia escolhida, no sentido de verificar, antes, o atual ensino do desenho técnico arquitetônico nestas mesmas escolas/ faculdades. Para a pesquisa inicial sobre a cotagem, necessário era perpassar, rapidamente, pelo atual estado do ensino do desenho técnico arquitetônico. O que é fundamental transmitir aos alunos? É uma questão de padronização, de um conjunto de convenções e, portanto, de que os alunos pesquisem e aprendam, por conta, nos mais variados livros e manuais de desenho técnico e/ou de desenho arquitetônico? Atualmente, é necessário ensinar ou não esta matéria? Hoje, é razoável que, não dispondo muitas escolas de carga horária suficiente para ensinar o desenho arquitetônico, deixem e até insinuem aos alunos a que procurem aprender esta matéria fora da escola, no mercado, já que se trata apenas de um punhado de convenções e normas? 0 que se apresentava como um expediente a ser abordado de modo rápido, tornouse, pelos procedimentos da pesquisa, o novo foco a ser visto com atenção. Tornou-se mais importante estudar, antes, o âmbito do ensino de desenho técnico arquitetônico como um todo do que uma particularidade dele, que é a cotagem ou dimensionamento. 
Em geral, as escolas/faculdades de arquitetura têm atribuído, atualmente, menos horas-aula, menos atenção ao desenho técnico arquitetônico que nos passado. Algumas radicalizaram e abandonaram, de vez, uma disciplina que contemplasse esta matéria - talvez isto possa representar um problema. Outras, nunca tiveram uma disciplina própria, com ênfase para este assunto, como é o caso da FAU/USP, em São Paulo.

O autor desta pesquisa é professor de desenho arquitetônico, desde 1999, na graduação (alunos do primeiro ano) do Departamento de Arquitetura e Urbanismo desta Escola em que este Programa de Pós-graduação está inserido. No ensino médio, fez curso profissionalizante em Edificações e complementou sua formação, graduando-se arquiteto pela Universidade Federal do Paraná, Curitiba, em 1985, onde o ensino de desenho arquitetônico era sólido; e trabalhou, em boa parte de sua vida profissional, com desenhos executivos de arquitetura para outros arquitetos ou escritórios de arquitetura. De volta à academia, traz toda a bagagem de conhecimento e experiências na área de desenho técnico. Mas, percebe uma falha na parte conceitual e reflexiva desta disciplina - vítima, reconhece, certamente, da avassaladora corrida que o mercado exige da vida profissional - e reage (ou tenta reagir) com o fim de assimilar e refletir conceitualmente, adequando-se aos novos modos de ensinar buscando leituras de novos textos, sobre a essência do desenho como um todo, como linguagem, como instrumento de comunicação, sobre o que realmente é importante transmitir aos alunos etc.

Por outro lado, percebe, também, um enfraquecimento ou desleixo no ensino de desenho técnico arquitetônico, como o das plantas, cortes e vistas etc., o que se constituem desenhos básicos, linguagem mínima de todo arquiteto. Esta é a razão deste trabalho, a de verificar, de constatar o atual estado de ensino desta matéria, que considera importante.

Constatou também alguns indícios que diagnosticam esta situação: a freqüente queixa dos professores, principalmente os de Projeto, de que os alunos não sabem desenhar; e os atendimentos a trabalhos de graduação de alunos do último ano, em que se verificam, na maioria das vezes, desenhos inconsistentes. Além disso, verificou o pouco conhecimento e prática de desenho arquitetônico dos estagiários que trabalharam com ele.

Tais desenhos denunciam falhas em três aspectos: o não-entendimento completo da aplicação da geometria projetiva em desenhos de arquitetura, não havendo, em muitos casos, correlação exata entre plantas, cortes e/ou vistas; o desenho em si, inexpressivo, insosso, vacilante, que denota a ausência da 
prática das técnicas de grafismo e, muitas vezes, fora do esquadro, revelando, também, pouca prática no manejo dos instrumentos; e, por fim, não saber, perfeitamente, o que está representando com o desenho, evidenciando não conhecer os materiais de construção e seus desempenhos, o sistema estrutural adotado etc. Deste último, sabemos bem, os alunos não desenham o que não conhecem, podendo até prejudicar a proposta arquitetônica, enveredando por soluções mais simples ou triviais, por falta de conhecimentos técnicos da construção.

Essas constatações nos remetem a uma auto-indagação: ensinamos efetivamente desenho arquitetônico? Como preparamos essas aulas? Gozamos de número de horas-aula necessárias para o ensino e acompanhamento da prática dos alunos? Que metodologia adotamos? Que recursos utilizamos? Ou, infelizmente, achamos que o ensino de desenho técnico arquitetônico não é importante?

No decorrer dos estudos da arquitetura e no atendimento às dinâmicas da sociedade, além do desenvolvimento de novas tecnologias e do surgimento de novos materiais, novos saberes se acrescentaram e/ou foram reivindicando espaços de carga horária no ensino das escolas de arquitetura. Talvez as disciplinas de desenho tenham sido as que mais foram retaliadas.

A simplificação do desenho, a elaboração das normas técnicas de desenho, a publicação de manuais de desenho arquitetônico etc. constituem fatores que contribuíram para conferir menor importância ao ensino e prática de desenho técnico arquitetônico. Também as escolas técnicas, de ensino profissionalizante, principalmente os cursos técnicos de edificações, cumpriram o papel de formadores de bons projetistas e desenhistas e causaram, indiretamente, uma transferência de responsabilidades do ensino de desenho técnico arquitetônico a estas escolas. O CAD também se alia a estes fatores, no sentido que propicia a homogeneização do desenho.

Para além destes fatores, talvez o que mais pese em todo esse processo de "enfraquecimento", de um certo indiferentismo frente ao desenho técnico arquitetônico seja o pensamento, acertado em termos, de que é preciso formar arquitetos, não desenhistas. 0 afastamento do arquiteto do canteiro, do edifício, trazendo para si mesmo novas atribuições e responsabilidades no contexto do Brasil em desenvolvimento, ligado à esfera do planejamento, implicou a diminuição da atenção ao desenho. Há, ainda, uma questão estudada por PUNTONI (1997), que os programas de ensino nas escolas de arquitetura 
e os planos de trabalho pressupõem que o aluno já tenha conhecimento de geometria euclidiana, geometria descritiva e desenho técnico, e que já esteja treinado a produzir desenhos, o que, na prática, comprova não ser verdade.

Este enunciado de fatores do "não-desenho", do desleixo radical ou quase radical quanto ao desenho técnico arquitetônico, notadamente em tom de queixa, na condição de professores que somos, que, aliando e fazendo eco a arquitetos mais experientes e antigos - parecem escapar de nossas mãos, com dor, com o sentimento de que o campo da arquitetura está perdendo algo importante e vital, que é o ensino e prática do desenho, seja livreexpressivo, seja técnico, como ferramenta do processo do projeto. Tom de queixa, de aparente passividade e, ao mesmo tempo, de compreensão da atual situação e das circunstâncias decorridas, que nos instiga, positivamente, a uma reação, a uma reflexão. Primeiramente, na proposição de uma questão fatal: é importante ou não o ensino de desenho técnico arquitetônico nas escolas/faculdades de arquitetura? Depois, se a resposta for afirmativa, até que ponto as escolas devem ensinar, qual a essência a ser transmitida aos alunos nesta matéria?

Um conjunto de linhas lançadas num papel branco estruturam ou iniciam a estruturação de um raciocínio, de um pensamento, de uma idéia ou já formalizam alguns volumes. Imediatamente, isso nos remete a outras idéias, o diálogo se estabelece entre criador e criação através de um intrumento simples que é o lápis, num suporte, igualmente simples, que é o papel. Novas linhas, por cima das já desenhadas, vão surgindo. Manchas denunciam setorizações; texturas podem apontar sombras e penumbras e demarcam diferentes planos volumétricos ... As idéias vão surgindo e se consolidando em formas mais concretas. São os desenhos enquanto criação do objeto arquitetônico.

De modo análogo, no desenho técnico arquitetônico, paralelamente ao deslizar da lapiseira para desenhar uma linha de revestimento de uma parede, o pensamento pode estar ativamente refletindo sobre esse revestimento, seu impacto ou não na composição espacial, sua materialidade, a ação da luz sobre ela, suas proporções etc. Antes até, a elaboração do desenho técnico de um corte nos traz novas informações, proporções a serem acertadas, pés-direitos a serem verificados, pensamentos sobre os espaços de tubulações horizontais de projetos complementares no entre-forro etc. E cotar, precisar uma medida, é reflexo de trabalho anteriormente pensado, relativizado, levando em conta proporções, custos, ergonometria etc.

Paradoxo do ensino, até quando vamos conviver com esta incongruência: "os alunos não sabem desenhar, mas nós, professores, não ensinamos"? 0 
quê ensinar, o quê importa resgatar para elevá-lo à sua correta posição, em importância e essência?

Para tanto, na busca de procedimentos de aferição, de verificação desta situação, avançamos em três direções: coleta, catalogação e análise de manuais de desenho arquitetônico; elaboração, aplicação e análise de resultados de um questionário dirigido a professores desta matéria e de CAD das principais escolas de arquitetura do Brasil; e, ainda, entrevista com arquitetos e/ou professores.

A partir disto, conseguimos organizar este trabalho numa estrutura simples e objetiva, estabelecendo uma seqüência onde o primeiro capítulo aborda a fundamentação teórica e metodológica do desenho de arquitetura; o segundo trata da constatação do atual ensino propriamente dito, permeado de comentários pertinentes extraídos das entrevistas dirigidas aos arquitetos e/ou professores; e o terceiro capítulo dedica-se à análise das respostas do questionário aplicado aos professores, enquanto que o quarto e último capítulo trata de classificar e examinar, criticamente, os principais manuais/livros de desenho arquitetônico disponibilizados aos estudantes de arquitetura.

Para a análise dos livros/manuais de desenho arquitetônico, efetuamos seu levantamento nas seguintes fontes: Biblioteca da FAU/USP Cidade Universitária - São Paulo-SP; Biblioteca da FAU/USP Maranhão - São Paulo-SP; Biblioteca Central da EESC / USP - São Carlos-SP; Biblioteca da FAU/Mackenzie - São Paulo-SP; Biblioteca Central da UFPR - Curitiba-PR; e Biblioteca Central da PUCPR - Curitiba-PR. Alguns manuais levantados foram extraídos de bibliotecas particulares de alguns colegas professores do Departamento de Arquitetura e Urbanismo da EESC/USP de São Carlos. A pesquisa nas bibliotecas de Curitiba foram realizadas pela facilidade do autor de se deslocar para lá, cidade de seus pais e, também porque se graduou na UFPR, em 1985, como já foi mencionado.

Este trabalho, no intento de buscar as raízes causadoras do empobrecimento do ensino de desenho arquitetônico, nos instiga à auto-reflexão e à revisão de alguns pontos, na esperança de, positivamente, irmos criando uma nova postura de atuação, reposicionando esta matéria no seu estado de importância, em favor do aumento qualitativo do ensino de arquitetura das escolas brasileiras de arquitetura e urbanismo e, conseqüentemente, de uma melhor capacitação profissional do arquiteto. 


\title{
Desenho de arquitetura
}

\begin{abstract}
Alguém poderia perguntar se é possível imaginar um edifício sem desenhá-lo. Embora existam, eu presumo, outros métodos de descrever as idéias de arquitetura de alguém, existe uma pequena dúvida em minha mente sobre a capacidade de a imagem desenhada descrever a vida imaginada de um edifício. Se estivermos finalmente discutindo a qualidade da arquitetura que resulta de um modo de conceitualização, então certamente o nível de excelência será aumentado pelo componente de investigação derivado da arte do desenho em si. Sem a disciplina do desenho, pareceria difícil utilizar na arquitetura a vida imaginada que tem sido previamente registrada e simultaneamente entendida através da idéia desenhada.
\end{abstract}

Michael Graves apud ROBBINS, 1997, p.47

Entendendo que este trabalho é uma reflexão, uma pesquisa sobre o desenho arquitetônico - mais precisamente sobre o desenho técnico arquitetônico: a correta representação gráfica de plantas, cortes, vistas, suas convenções, as cotas e especificações, a comunicação entre os desenhos etc. - e uma constatação do seu atual ensino nas escolas de arquitetura do Brasil, este capítulo proporciona uma definição deste tipo de desenho, alguns aspectos de sua história, e sua finalidade e importância. 
Para tanto, faz-se necessária uma explicação: o desenho arquitetônico é um desenho técnico. E, no decorrer deste assunto, ora haverá referências ao desenho técnico, ora ao desenho arquitetônico, transitando naturalmente entre eles, sem um ferir ao outro, pois eles se complementam e se verifica que o desenho arquitetônico nada mais é que um desenho técnico arquitetônico. Por outro lado, pode-se observar que, apesar de esta pesquisa se ater somente ao desenho técnico arquitetônico, não poucas vezes haverá referências aos desenhos iniciais, desde o croqui, às primeiras ações do arquiteto em projetar arquitetura. Insinuam-se, já aqui, duas conotações, em etapas diferentes, do desenho de arquitetura: a de concepção e a de viabilização.

Neste capítulo, estas discussões são tratadas, principalmente, a partir da leitura de textos sobre o assunto, destacando-se os trabalhos de tese de Doutorado de PERRONE (1993) e PUNTONI (1997) e as dissertações de Mestrado de FIALHO (2002) e ORTEGA (2000), orientados pelos primeiros e, sobretudo, a obra de SAINZ (1990)1' El dibujo de arquitectura. Teoria e História de un Lenguaje Grafico, que se apresenta como um referencial importante neste vasto campo do desenho de arquitetura. O livro Le graphisme technique. Son histoire et son enseignement, de Yves Deforge (1981), deu-nos aporte na área de desenho técnico, nos aspectos conceituais e históricos. Todas as citações de autores estrangeiros aparecerão traduzidas.

Desenhos de croqui de plantas, vistas, secções e perspectivas, rapidamente esboçadas ou bem elaboradas e acabadas - com suas técnicas de cor, texturas, claros-escuros, densidade, fundo-figura, composição etc., feitos a mão ou com o auxílio do computador - além dos desenhos técnicos de arquitetura, perfazem o conjunto do desenho arquitetônico ou desenho de arquitetura, em suas várias etapas de desenvolvimento e diferenciações para cada destinatário. Linguagem própria do arquiteto (supõe-se que o seja), estes desenhos se apresentam como ferramenta básica para comunicar suas intenções ao cliente contratante ou a outros profissonais do meio da construção civil. Constituindo-se num autêntico sistema gráfico, são o melhor meio para passar da idéia arquitetônica à sua realização. Jean Nicolas Louis Durand, professor de arquitetura na Escola Politécnica de Paris e discípulo mais próximo de Boullée, escrevia que o desenho é a linguagem natural da arquitetura (DURAND, 1819 apud SAINZ, 1990, p.53).

Jorge Sainz complementa:

[...] quando ditos pensamentos se referem ao campo da arquitetura o meio mais idôneo não é o oral ou o escrito, mas o gráfico. [...] se põe o acento pela primeira vez na qualidade do desenho como transmissor dos raciocínios e intuições dos arquitetos, bem seja
1 Jorge Sainz

é professor do

Departamento

de Composición

Arquitectónica da

Escuela TS de

Arquitectura de Madrid e colaborador habitual da revista espanhola

Arquitectura Viva (Jsainz@aq.upm.es, 04.07.2003). 
entre eles mesmos ou com outras pessoas implicadas no processo edificatório (clientes, autoridades, etc.) (SAINZ, 1990, p.53).

O desenho técnico arquitetônico, o das plantas, cortes etc., nada mais é que um desenho técnico; é linguagem comum também entre os feitores - engenheiros, projetistas e consultores - dos projetos complementares: de estrutura, de hidráulica e elétrica, ar condicionado, instalações outras etc.

Jorge Sainz (1994, p.80) escreve que "desenhar, em geral, é plasmar sobre uma superfície plana bidimensional a imagem de um volume tridimensional com os recursos dos sistemas de geometria descritiva e projetiva, para conseguir a transposição de três para duas dimensões".

Nos seus variados graus de complexidade, o desenho arquitetônico é apreendido desde o leitor leigo, quando este vê uma ilustração de uma planta num prospecto de venda imobiliária, até os atores mais especializados em projetos, cálculo e construção civil, além de especialistas críticos da arquitetura. Por este viés, Luigi Vagnetti - um dos estudiosos mais interessados no desenho de arquitetura - qualifica a obra arquitetônica como um campo de forças seletivo que atrai tão somente as sensibilidades formadas (SAINZ, 1990, p.29).

No entanto, o desenho é uma abstração da mente humana e é sempre uma representação gráfica que explica, ou tenta explicar, uma realidade. FIALHO (2002, p.23) afirma que os conceitos de ponto, reta e plano, sem os quais o homem estaria privado de um modo racional para compreender e representar o que atribui como sendo o espaço, não são encontrados na natureza, pois constituem abstrações.

Há autores que se empenham em repetir que não há nenhum tipo de representação gráfica que possa oferecer uma imagem completa da obra arquitetônica. Na realidade, é evidente que nenhuma representação possa substituir o conhecimento direto da realidade. No campo da arquitetura, nem o mais exaustivo conjunto de planos, vistas, fotografias, películas e maquetes poderá substituir a experimentação real e pessoal dos valores arquitetônicos de um edifício concreto. O importante, no entanto, é assinalar que entre os objetivos ou pretensões da representação gráfica não se encontra o de substituir a experiência direta" (SAINZ, 1990, p.28-9).

O desenho é sempre uma interpretacão e, como estabelece MASSIRONI (1982, p.72), "é um equívoco pensar que equivale à reprodução verídica, fiel à realidade". Certificamo-nos disto pela experiência espacial, física e real de Bruno Zevi: 
[...] onde quer que exista uma perfeita experiência espacial a viver, nenhuma representação é suficiente, precisamos nós mesmos irmos, sermos incluídos, tornarmo-nos e sentirmo-nos parte e medida do conjunto arquitetônico; devemos nós mesmos nos mover. Todo o resto é didaticamente útil, praticamente necessário, intelectualmente fecundo; mas não é mera alusão e função preparatória dessa hora em que, todos nós, seres físicos, espirituais e sobretudo humanos, vivemos os espaços com uma adesão integral e orgânica. Será esta a hora da arquitetura (ZEVI, 1994, p.51).

Parece evidente, porem, que a arquitetura, tal como entendida ao longo da história, tem o desenho como "instrumento tão essencial como a própria construção" (RAMIREZ in prólogo de SAINZ, 1990, p.11), numa relação que mantém o desenho ligado ao desenvolvimento e à evolução da própria arquitetura. Mesmo que o edifício não tenha sido construído, seus desenhos constituem provas valiosas das intenções arquitetônicas do autor. São desenhos do tipo documental.

Em geral, não se cria e se constrói um edifício, com certo grau de complexidade, sem uma representação prévia mais ou menos esquemática, ou seja, sem um projeto. 0 desenho, com suas várias finalidades e atributos, em seus diversos tempos ou fases de um projeto para diferentes destinatários, constitui o meio mais eficaz do desenvolvimento do pensamento, criação, registro e viabilização arquitetônica.

Um breve histórico social, cultural e técnico do desenho

O desenho, hoje, é a forma natural e universal do discurso arquitetônico, em que o arquiteto conceitua, desenvolve, apresenta e realiza suas idéias arquitetônicas. Ferramenta prática, objetiva e social da produção material da construção, FIALHO (2002, p.11) afirma que é, também, representação conceitual, subjetiva e cultural de uma criação arquitetônica.

$\mathrm{Na}$ edificação medieval o mestre-de-obras combinava em si mesmo as atribuições de empreiteiro, construtor e administrador. Na grande maioria das vezes, os desenhos do arquiteto medieval apresentavam, efetivamente, apenas medidas, as quais o arquiteto poderia alterar. 0 resto era emprestado de outros edifícios.

[...] Os desenhos serviam-lhe para ilustrar suas idéias sobre a obra junto aos seus colaboradores, de modo a permitir-lhes que participassem com as idéias referentes às suas especializações 
profissionais. A obra, como um todo, era definida no canteiro de obras e correspondia a uma somatória das contribuições dos profissionais arregimentados para a sua execução, como se fosse uma colcha de retalhos. Não existiam, portanto, os projetos arquitetônicos e tecnológicos, como os entendemos atualmente. Havia os traçados para a produção dos elementos construtivos e, quando muito, algumas figurações gráficas das fachadas. $O$ intento de um mestre-de-obras era construir, o que compreendia a concepção do objeto, e para isso reunia um grupo de profissionais competentes e disponíveis. Os edifícios, quanto à sua disposição dos planos e suas formas, eram construídos em função do que se conhecia sobre outros edifícios, anteriormente construídos (PUNTONI, 1997, p. 32)

A partir do Renascimento, por volta de 1400, parece ser Filippo Brunelleschi (1337-1446), considerado o cientista e artista mais criativo da época - uma vez que não havia então quase nada que pudesse receber o nome de ciência criativa - quem define o caminho da ciência em sua geração, com a criação da sua teoria da perspectiva por meios experimentais (SANTILLANA, 1981, p.29). Desencadeou-se a partir daí o desenvolvimento do desenho em escala, juntamente com modelos matemáticos para o projeto.

Num viés sociológico, ANDRADE (1986, p.54) escreve que, a partir de Brunelleschi, dá-se uma ruptura profunda entre o mestre-de-obra e o novo arquiteto, que surge e reclama para si toda atribuição exclusiva da direção da produção, numa separação radical entre o trabalho manual e o trabalho intelectual.

O arquiteto assim alcança um novo status cultural e social no Renascimento: o de projetista conceitual, acompanhado da nova centralidade e importância do desenho como um instrumento crítico da criação e produção arquitetônicas. FIALHO (2002, p.12) escreve que a auto-invenção do arquiteto como trabalhador intelectual, seria acompanhada do uso extensivo do desenho como instrumento dessa invenção e, neste contexto, a progressiva função do desenho certamente promoveu uma poderosa base instrumental para esta nova definição da função do arquiteto, que the proporcionava a possibilidade de expressar e experimentar uma variedade de idéias maior do que o fazia o desenho medieval, além de poder trabalhar fora da obra e estar envolvido em vários projetos simultâneos.

SAINZ (1990, p.112-13) estuda que Leon Battista Alberti expõe em seu livro De pictura, a sistematização da teoria e a prática da perspectiva, pois, até então, não se conseguia apreciar as medidas verdadeiras, senão por aproximação intuitiva (o uso da perspectiva foi constante desde a sua codificação no Renascimento, mas não é freqüente encontrar textos que considerem um 
método adequado para a representação especificamente arquitetônica). Mais tarde, em De re aedificatoria (1485), Alberti adverte que o arquiteto só deva representar seus projetos através da planta e da secção. Na sua época, nem sequer a ortographia de Vitrúvio (1486) era considerada imprescindível para se construir edifícios. Como em muitos outros aspectos, devemos a Vitrúvio as primeiras referências escritas acerca do modo de representar um edifício sobre uma superfície, mas estas não chegaram a ser de geral conhecimento até finais do século XV.

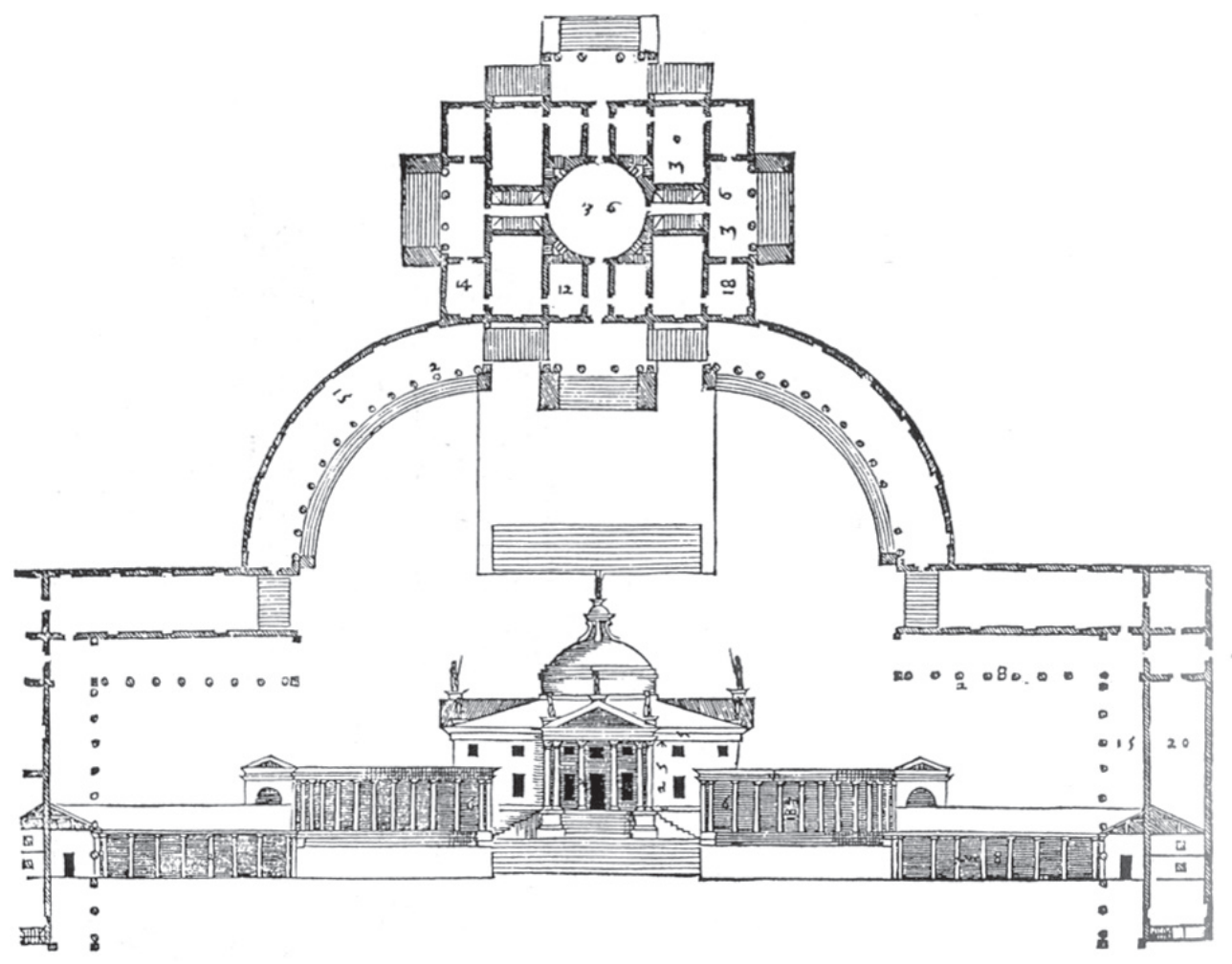

A carta de Rafael (1519) a León X - continua SAINZ - marca, sem dúvida, um ponto importante na consideração dos sistemas de representação em arquitetura. Rafael completa as idéias de Vitrúvio e Alberti e descreve, com todos os detalhes, as três projeções ortogonais básicas: a planta (la pianta), o alçado (la parete di fuora) e a secção (la parete di dentro). Andrea Palladio (1570) em I quattro libri aplica a teoria de Rafael, utilizando as projeções ortogonais e buscando o rigor das medidas. Todos os sistemas de projeção mencionados ficaram definitivamente codificados com Gaspard Monge, grande matemático francês que, em 1798, estabeleceu as bases da geometria descritiva, e codificou de um modo estritamente científico todos os sistemas de
Fig.[1] 1

Andrea Palladio. Villa Trissino em Meledo: planta e fachada; xilografia. De I quattro libri, 1570. 
representação utilizados pela arquitetura: projeções ortogonais, perspectivas e axonometrias. Acrescentou ainda a projeção oblíqua, imprescindível para o cálculo científico das sombras próprias e arrojadas, dando entrada assim a uma variável que sempre se havia utilizado de um modo intuitivo, aproximado ou, em todo o caso, pictórico (SAINZ, 1990, p.52).

Para Monge, a geometria descritiva tem dois objetivos:

O primeiro, dar métodos para representar sobre uma folha de desenho que não tem mais que duas dimensões, comprimento e largura, todos os corpos da natureza que têm três, comprimento, largura, profundidade. O segundo, dar a maneira de reconhecer segundo uma descrição exata, as formas dos corpos e de deduzir todas as semelhanças que resultam de suas formas e de suas respectivas posições (DEFORGE, 1981, p.54).

O uso instrumental da representação gráfica exigia certo grau de convencionalidade para que todo aquele que conhecesse suas regras pudesse compreender perfeitamente o representado.

Os projetos de edifícios, como todas as representações de objetos que se possam construir, têm exigências que se satisfazem plenamente com o uso das projeções orotogonais. Estas possuem uma série de propriedades geométricas que são muito adequadas para a representação dos objetos tridimensionais, a saber: 1 , a escala, quer dizer, a relação conhecida e constante entre as medidas do objeto desenhado e as do objeto real; 2, a semelhança de superfícies, isto é, a permanência no objeto real das figuras geométricas planas representadas; 3 , a constância dos ângulos, ou seja, a identidade dos ângulos representados e os reais; e 4, a constâncias das proporções ou, o que é o mesmo, a igualdade das relações entre as distintas dimensões do real e as do representado (SAINZ, 1990, p.114).

A obra de Monge é um hiato na evolução da representação gráfica da arquitetura. A partir deste momento se pode falar claramente de um sistema gráfico que serve de apoio à criação e representação de edifícios. Segundo suas leis, cada objeto se pode reproduzir, dentro de um determinado sistema de representação, de um modo unívoco e independente do executor material do desenho (SAINZ, 1990, p.52).

SAINZ (1990, p.122), por fim, alega que o sistema de projeção ortogonal se usava de modo intuitivo desde a Antigüidade, e que foi somente codificado cientificamente em fins do século XVIII. Um exemplo disso poderia ser o desenho de planta do monastério de St. Gallen, o primeiro desenho de arquitetura - em sentido estrito - que chegou até nós e remonta a princípios do século IX: 


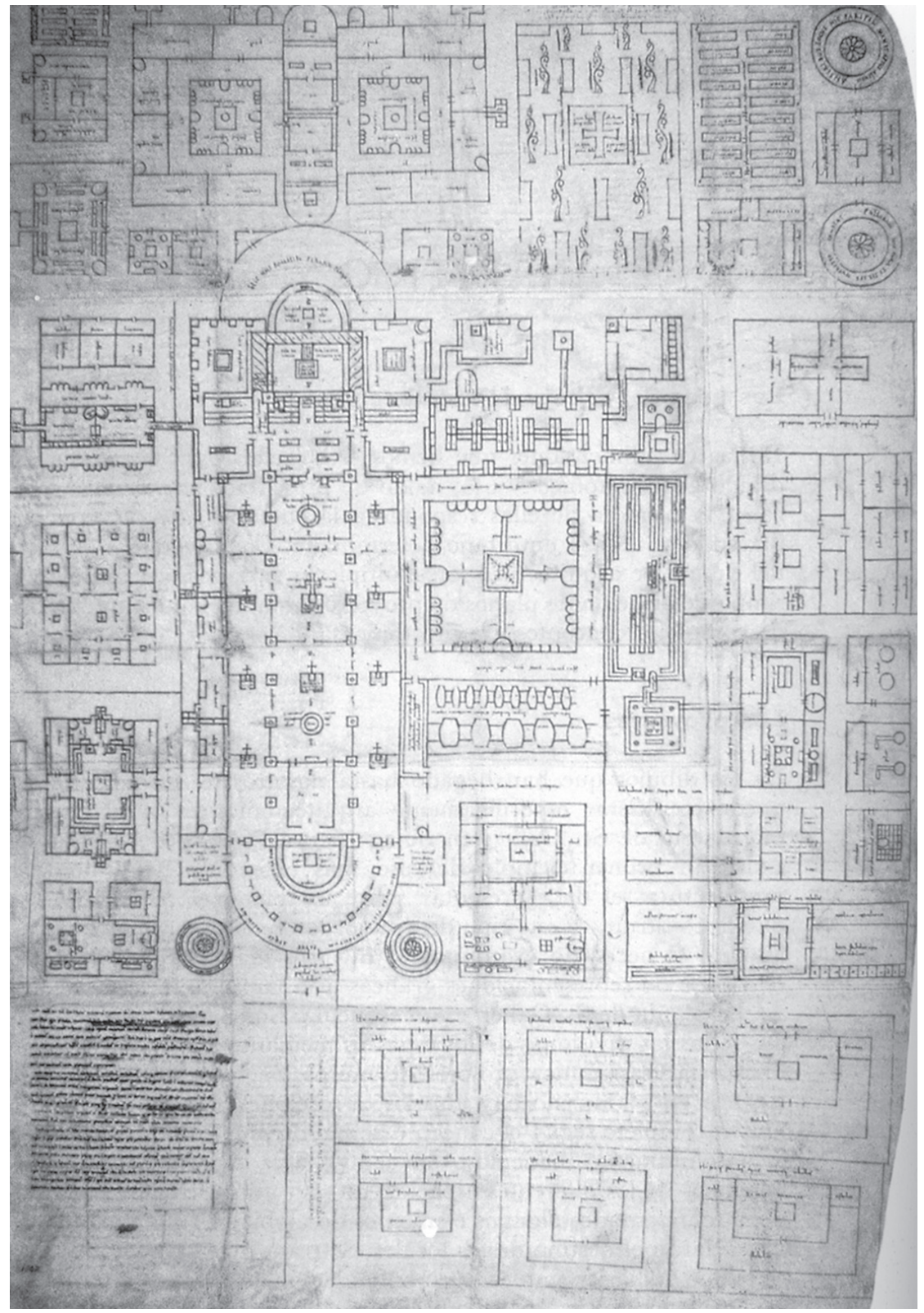

Dos desenhos que chegam até nós, o primeiro que pode-se considerar especificamente arquitetônico é a planta do monastério de St. Gallen, na Suiça (estima-se o ano de 820 d.C). [...] A planta de St. Gallen é um esquema. Nela estão representadas todas as divisões dos espaços através de linhas simples, praticamente sem diferenciar as espessuras de parede. Trata-se tão somente de um traçado em planta; não há fachadas nem secções, e está muito incompleto segundo o conceito atual de projeto. No entanto, é absolutamente meticuloso quanto à especificação de funções dos diferentes espaços; não só utiliza rótulos como tem representados alguns elementos de mobiliário e equipamento que esclarecem o destino dos lugares. Trata-se, pois, de um projeto tipo, que poderia ser empregado na fundação de novos monastérios beneditinos, adaptando-se suas alturas, materiais e técnicas construtivas aos usos e costumes dos diferentes países. Era, portanto, um monastério ideal (SAINZ, 1990, p.77-9).
Fig.[1] 2

Autor desconhecido, até o ano 820. Monastério de St. Gallen; planta; pluma e tinta preta e vermelha sobre pergaminho; $112 \times 78 \mathrm{~cm}$. Stiftsbibliothek, St. Gallen. 
Fig.[1] 3

Autor desconhecido, até o ano 1275. Catedral de Estrasburgo, projeto A; fachada, tinta sobre pergaminho. Musée de l'Oeuvre de NotreDame, Estrasburgo.
Os primeiros projetos entendidos em seu pleno sentido instrumental remontam já ao século XIII, nas logias medievais das catedrais góticas. Os desenhos de planta de edifícios completos eram mais escassos, já que na Alta Idade Média bastava um simples esquema, pois, em geral, um tipo de planta correspondia necessariamente a um tipo de fachada; até o século XIII - e sobretudo a partir do XV - os construtores góticos começaram a realizar desenhos esmerados e muito detalhados que, em sua qualidade instrumental, não foram superados pelos que contemporaneamente se estavam realizando na Itália (SAINZ, 1990, p.79).

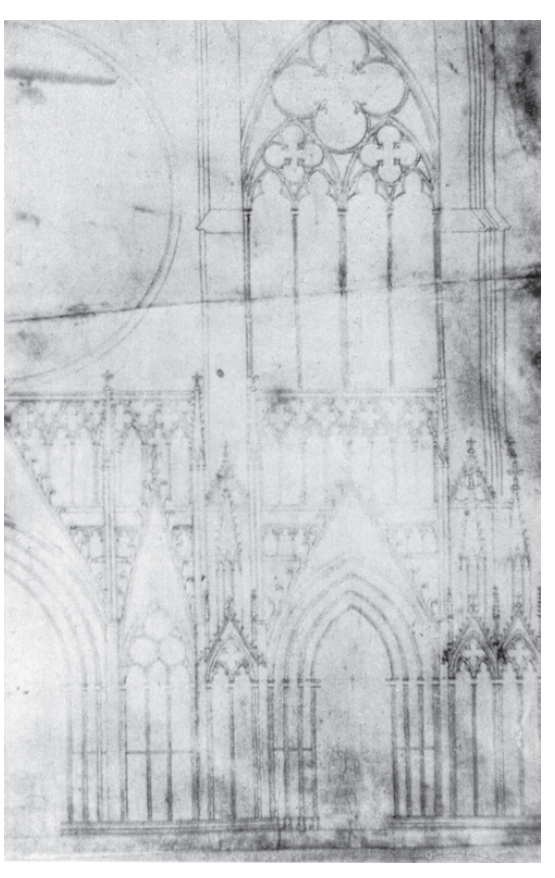

Hoje, o desenho arquitetônico está todo sistematizado com suas convenções e simbologias próprias, e pode, ainda, desenvolver-se mais em função de novos modos de pensar e fazer arquitetura, de novas tecnologias, novos procedimentos construtivos que exigiriam novas formas de representar etc. Acreditamos que sua sistematização muito se deu nos moldes do desenvolvimento do desenho técnico (mecânico), em que organismos de padronização buscavam a racionalização, precisão (milimétrica) e comunicação eficazes entre seus pares.

Constituindo-se o desenho como instrumento pelo qual o arquiteto transforma o conceito num objeto construído e como ferramenta e meio principal de comunicação entre os arquitetos, outros profissionais e o cliente, podemos observar uma série de diferentes relacionamentos entre eles, onde o desenho apresenta características de cunho social e cultural.

Os escritórios de arquitetura apresentam soluções variadas de quem desenha nas diferentes etapas do processo de projeto. Dependendo da grandeza do 
projeto, organizam-se em grandes grupos de trabalho, envolvendo vários profissionais, hierarquizando funções e delegando tarefas a cada qual, da melhor forma possível, como num processo produtivo. 0 desenho de trabalho credencia o arquiteto ou outro profissional da área a dirigir a produção de cada elemento de projeto, através da especificação precisa de cada detalhe, sem estar constantemente presente para supervisonar o trabalho. FIALHO (2002, p.15) afirma que as diferenças entre estes escritórios são freqüentes e aparentes: alguns arquitetos trabalham com detalhes minuciosos; outros deixam seus desenhos menos detalhados e permitem ao construtor trabalhar particularmente os detalhes construtivos e desenhá-los para a aprovação do arquiteto. 0 estilo e as convenções do desenho de trabalho variam de país para país, assim como de escritório para escritório. Há ainda escritórios que terceirizam parte de seus trabalhos, encaminhando-os a outros escritórios.

A história do desenvolvimento do desenho arquitetônico - principalmente devido à contribuição de Monge no desenho técnico -, além do seu papel social e cultural, apresenta-nos esta atual formatação: a do desenho e seus códigos como instrumento de comunicação numa rede socialmente organizada em hierarquias de funções e diferentes tarefas no processo produtivo de criação e viabilização de um projeto.

ORTEGA (2000, p.32) escreve que o arquiteto, tal como é conhecido, apareceu no Renascimento, e sua nova competência profissional se apoiou na representação exata do espaço, através de um conjunto de especificações e representações que possibilitou construir o espaço idealizado. Tal conjunto, hoje, é denominado projeto arquitetônico e, com isto, o desenho passou a ter a função de linguagem e a atender, dentro do continente da arquitetura, dois objetivos fundamentais: a criação da obra arquitetônica e a comunicação dessa criação. Como linguagem, o arquiteto se apropria do desenho para materializar soluções espaciais. 
Aproximasões do conceito e finalidade

[...] O fim último do desenho de arquitetura é a própria arquitetura.

(SAINZ, 1990, p.107)

No dicionário eletrônico Aurélio, desenho arquitetônico é o "desenho técnico, segundo processo de projeções, para representação de um edifício e seus detalhes através de plantas, cortes ou seções e elevações ou fachadas".

SAINZ (1990, p.41-60) estuda exaustivamente as diferentes definições do desenho arquitetônico, de vários autores e diferentes épocas. Alberti defendia: "Assim, pois, o desenho dos edifícios pertinente ao arquiteto se divide em três partes, das quais a primeira é a planta, quer dizer, o desenho plano. A segunda é a parede de fora com seus ornamentos. A terceira é a parede de dentro, também com seus ornamentos". O aporte de Rafael, que complementou os estudos de Alberti, é crucial: não se trata de uma planta que se complementa com uma maquete, mas de um autêntico sistema que, desde então, constitui o núcleo central de toda produção gráfica de arquitetura. Ele aposta claramente na utilização da projeção ortogonal nos documentos gráficos específicos da arquitetura e deixa as representações de caráter visual ou ilusório - as perspectivas - para as produções artísticas de natureza pictórica. O sistema planta-secção-fachada, como já citamos, não se codificou geometricamente até o surgimento da Géométrie descriptive de Gaspard Monge (1798).

Entre muitas definições analisadas por SAINZ, ele enuncia uma, analisada sob as dimensões de uso, modo de apresentação e técnica gráfica: "um desenho de arquitetura consiste numa imagem arquitetônica realizada dentro de um determinado estilo gráfico e com uma determinada finalidade arquitetônica" (SAINZ, 1990, p.43). Começa a aparecer a variável de finalidade.

O caráter específico do desenho de arquitetura - conclui SAINZ (p.21, 57 e 60) - constitui-se na forma mentis ou intencionalidade arquitetônica, que se concretiza na busca de um propósito extragráfico. Assim, o que distingüe o desenho de arquitetura dentro do meio gráfico é, precisamente, o fato de ter um objetivo/objeto arquitetônico. Trata-se de um meio necessário para conseguir um fim que é exterior ao próprio desenho. Seu caráter distintivo vem precisamente de seu objeto - a arquitetura - e da íntima relação que mantém com ela. 
Durand - escreve SAINZ (1990, p.97) - entendia o desenho em suas duas finalidades, a instrumental e a comunicativa:

O desenho serve para dar conta das idéias, seja quando se estuda arquitetura, seja quando se compõem projetos de edifícios; serve para fixar as idéias, de maneira que se possa, com toda tranqüilidade, examiná-las de novo e corrigi-las se for necessário; serve, enfim, para comunicá-las à continuação, seja aos clientes, seja aos diferentes contratistas que concorrem à realização dos edifícios; dá-se conta, depois disto, da importância que estas ações sejam familiares.

A finalidade arquitetônica, de acordo com FIALHO (2002, p.18-19), à primeira vista, é a de que o desenho de arquitetura constitua-se num meio de conseguir uma finalidade que é exterior ao próprio desenho - a execução material da obra. Na arquitetura, a função do desenho não é mimética, no sentido de representação, imitativa, mas criativa. Entretanto, existem diversas outras finalidades deste desenho. A dificuldade no estabelecimento de bases seguras para elaborar uma classificação para uma atividade tão interdisciplinar como o desenho deve-se à amplitude de seu raio de ação. A definição do desenho como signo da arquitetura, tese que defende PERRONE (1993, p.27-28), pressupõe uma condição de que, através dele, possam ser estudados os edifícios, desenvolvidos projetos e executados planos, e, em todos os sentidos elencados, a finalidade principal deve ser a de que a arquitetura possa ser conhecida e desenvolvida, que as novas e antigas concepções possam ser analisadas e utilizadas. 0 objeto final do desenho de representação da arquitetura deve ser, em primeira instância, a própria arquitetura.

\section{Alguns tipos de desenhos de arquitetura}

Os desenhos de croquis representam as etapas intermediárias do processo de criação e concepção da obra arquitetônica. "O traço dá conta de definir espaços, criar volumes, aferir proporções; ele estuda detalhes, sugere possíveis acabamentos, configura cenários urbanos" (SAHM, 1995). Destes esboços, desenhos a mão livre, as primeiras idéias são sucessivamente trabalhadas, formando desenhos mais técnicos, em escala e com algumas medidas; vão amarrando a idéia inicial, de forma tal que se constituem num instrumento para responder questões, mais que propô-las:

Existem três tipos de desenho que os arquitetos produzem quando trabalham no estágio inicial da conceituação do projeto. Existe o "croqui referencial", um tipo de diário ou registro de descobertas; 
${ }^{2}$ Edward Robbins é professor de Desenho Urbano no Graduate School of Design, Harvard University. Em 1997, escreve o livro Why architects draw em que examina o uso social do desenho de arquitetura, com base em entrevista com nove arquitetos contemporâneos. o "estudo preparatório", que documenta, de forma experimental, o processo de questionamento; e o "desenho definitivo", que é mais final e quantificável e é usado como "um instrumento mais para responder questões que para propô-las (Michael Graves apud ROBBINS, 1997, p.32) ${ }^{2}$

Guilherme Mazza Dourado, no artigo 0 croqui e a paixão, escreve que:

[...] o esboço de arquitetura captura as fantasias e os sonhos de materializar intenções de forma e espaço. Linguagem inteligível e ao alcance de todos e ao mesmo tempo de poucos, pelo sutil jogo de dissimulação de conteúdos expressos em simples riscos, numa síntese de complexidade do ofício de arquitetar.

[...] Usualmente - escreve ainda -, o esboço inicial é um tipo de desenho que não vem a público porque o arquiteto, como todo artista, acaba valorizando mais o produto final do que o processo temeroso, talvez, de mostrar as incertezas, indecisões e fraquezas que permeiam o trabalho criativo. Por outro lado, a exposição do croqui de estudo oferece argumentos para o debate sobre a complexidade da criação artística e intelectual, evidencia as relações dialéticas ou essencialmente contraditórias entre a concepção e a obra realizada.

[...] No processo de criação, a mente, a mão e os olhos são cúmplices que agem para transformar o imaterial em visual, em concretude. Mais que um mero suporte, a superfície do papel torna-se território de reflexão. Impulsivos ou comedidos, riscados de modo rápido ou tranqüilo, os primeiros contornos despontam como grafismos de reconhecimento: são insinuações, raramente inteligíveis aos olhares desatentos, mas esforços para determinar o caminho a seguir. Nem sempre registram de imediato resultados claros e definitivos. Como regra, precisam ser amadurecidos pela sobreposição de novas linhas, manchas e massas, pela alteração de proporções, pelo acréscimo de outras geometrias, pela eliminação do já superado. Ou se mostram exauridos, sem saída, obrigando ao recomeço em outra folha de papel.

[...] Nesse trabalho de depuração, o esboço vai ganhando força, vai evidenciando progressivamente as possíveis configurações volumétricas e espaciais da proposta. Recebe pequenas frases e anotações numéricas que explicam e precisam ainda mais seu conteúdo. Chega um momento em que tudo parece estar no seu lugar: o desenho, seja uma planta, um corte ou uma perspectiva, já estabelece o conceito global ou contém todas as informações necessárias para realizar a arquitetura (DOURADO, 1994, p.5052).

Na passagem das imagens mentais em estado de efervescência para o papel, o arquiteto registra com gestos impulsivos ou contidos formas preliminares que aos poucos vão configurando a totalidade da futura arquitetura (DOURADO, 1994, p.58). 


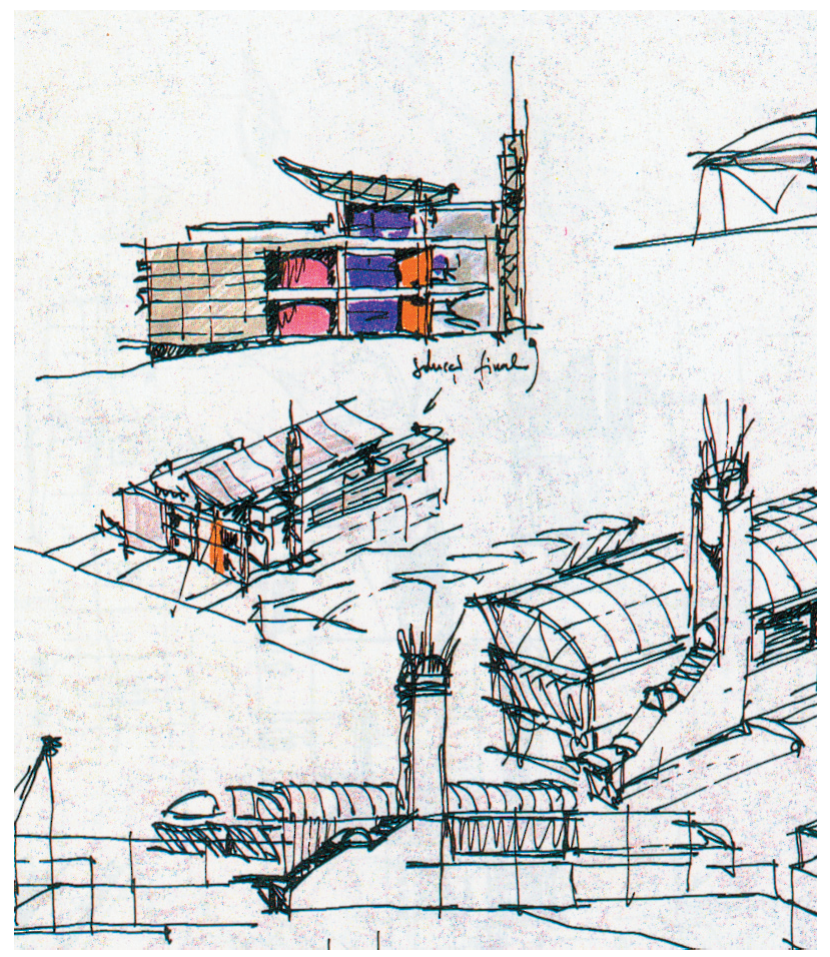

Traços e manchas nervosos com grafite grosso, caneta hidrográfica, giz registram o gestualismo solto mas firme, o risco aparentemente displicente mas significativo. A vontade urgente de aprisionar na superfície de desenho a idéia em ebulição (DOURADO, 1994, p.60).
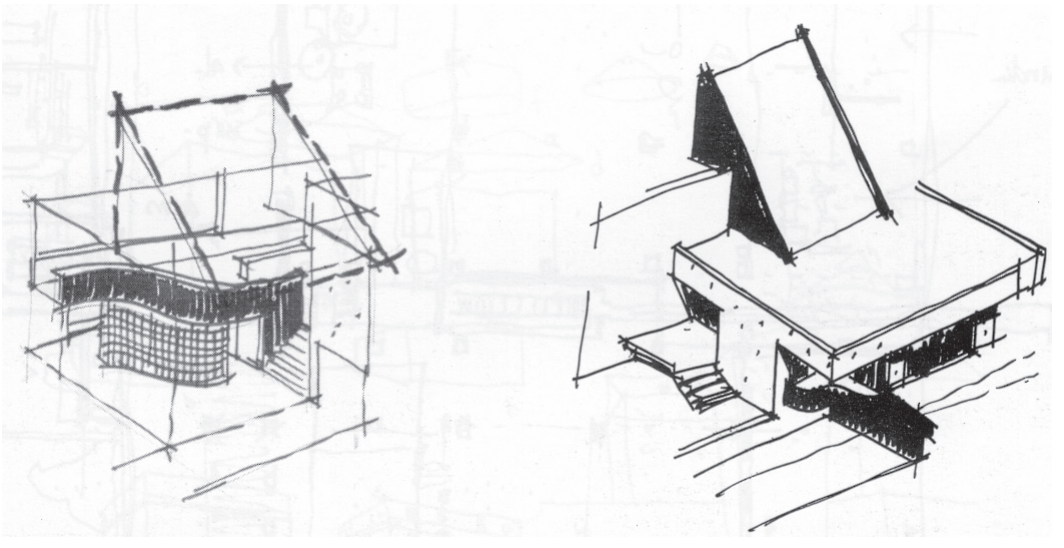

Saindo da seara da concepção/criação do projeto, em que o croqui desempenha um papel insubstituível, o Estudo Preliminar marca uma etapa clara, estabelecida por contrato, em que o arquiteto vai comunicar ao cliente as primeiras idéias. Nesta etapa, o trabalho é apresentado, em geral, por meio de plantas, algumas vistas e perspectivas - elaboradas de formas diversas, seja à mão ou em computador, colorido ou não etc. Não ocorre de maneira isolada, mas em combinação com a linguagem falada (e muitas vezes escrita) na transmissão do conhecimento conceitual, com maquetes (na maioria dos casos) etc. A partir daí, o arquiteto não dialoga somente consigo mesmo através dos desenhos, dos esboços iniciais, mas deve, com sensibilidade, munir-se dos
Fig.[1] 4

Sylvio Emrich Podestá. Edifício-sede da Microcity Computadores, Belo Horizonte.

Fig.[1] 5

Marco Antônio Gil Borsói. Residência em Brasília; caneta hidrográfica. 
recursos mais próximos, familiares, do conhecimento e repertório do receptor (o cliente ou comunidade) para transmitir suas idéias da melhor forma possível. $O$ desenho, linguagem do arquiteto, numa codificação mais aberta, é o recurso mais utilizado.

Fig.[1] 6

Daniel Libeskind. Teatro Msicon Bremem;

Bremem, Alemanha, 1995.

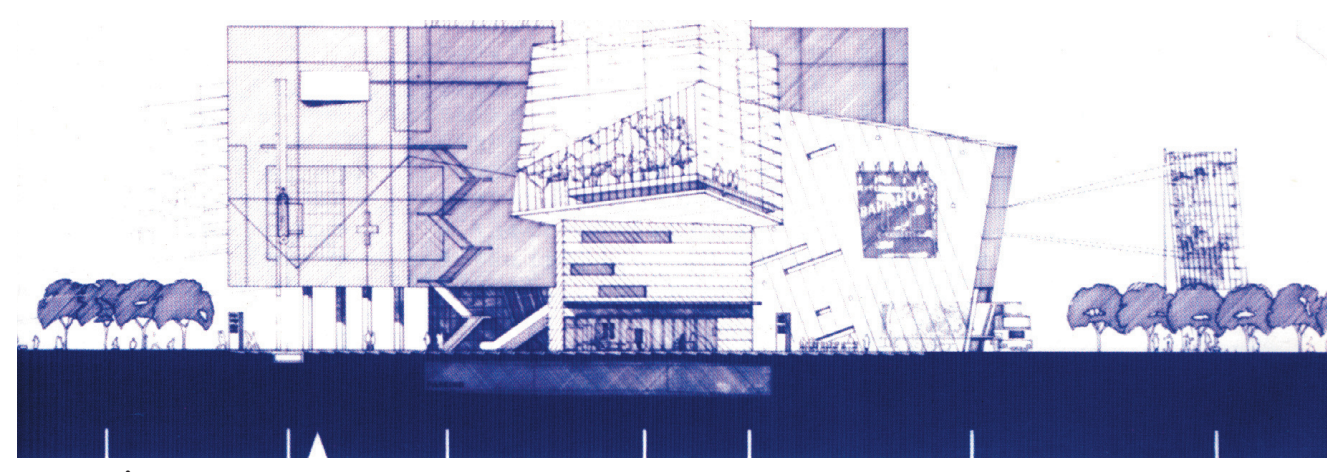

Dos três sistemas de projeções utilizados pelos arquitetos - plantas, cortes e vistas -, a perspectiva (projeção central ) é o que mais se assemelha à imagem que se produz em nossa retina e, portanto, o mais parecido à visão humana. Trata-se, pois, de um método que produz imagens diretas e facilmente legíveis. "Talvez seja esta a razão pela qual o estabelecimento científico das leis que a governam se produziu cerca de trezentos anos antes que o das projeções ortogonais" (SAINZ, 1990, p.122).

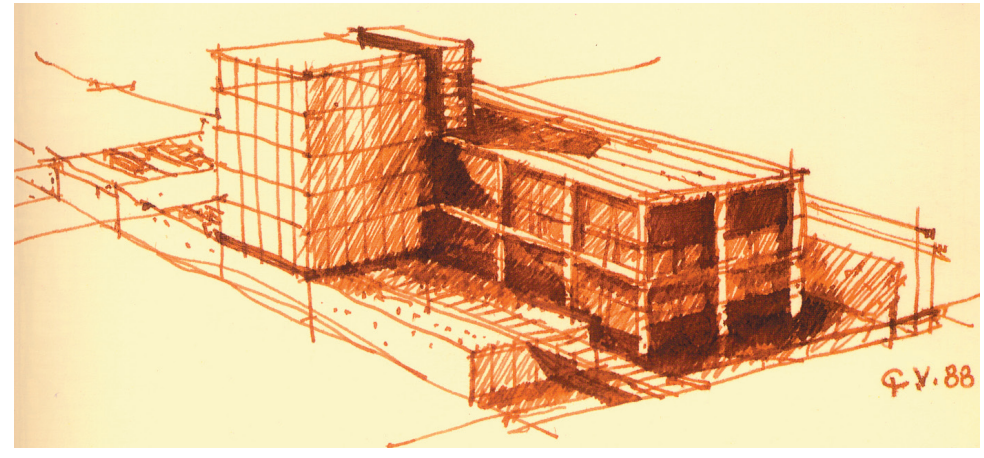

Fig.[1] 7

Cláudio Libeskind. Edifício-sede da Monark, São Paulo, 1988.

Fig.[1] 8

Bischof, Egozcue, Vidal, Bev Arquitectos/ Pastorino, Pozzolo. AMEBPBA Clinic, Buenos Aires, 1999.

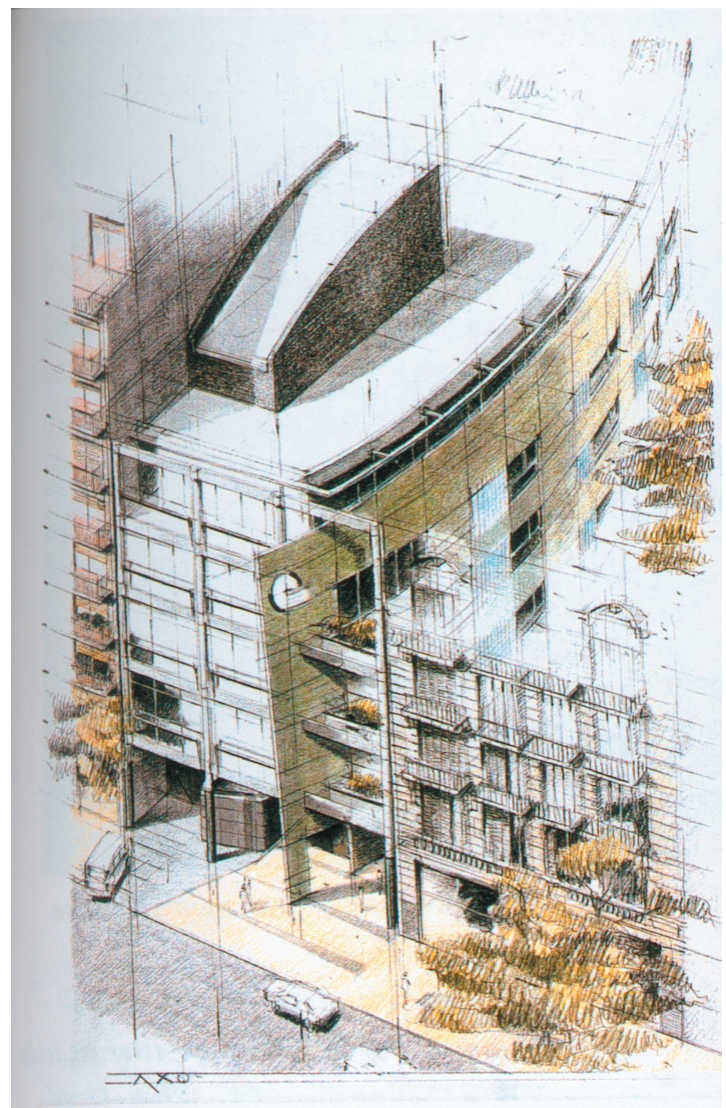


Nesta etapa importante, em que os conceitos e a idéia-mestre do projeto já se apresentam, o cliente tem a vez principal, na aprovação ou reprovação desta idéia inicial, além de sugerir algumas reivindicações de alteração, firmar novamente suas solicitações etc. Após esta etapa ser atendida, os desenhos se manifestam, agora mais precisos, na forma de Anteprojeto.

$\mathrm{Na}$ etapa do Anteprojeto, o arquiteto e o cliente realizam os acertos finais, revisões, para aprovar ou reprovar detalhes, sugerir ainda algumas pequenas alterações etc. Os desenhos vão se codificando, com uma gramática própria, e recebem um grau de precisão maior, os espaços propostos vêm mais detalhados etc. 0 próprio cliente, que já vinha treinando seu olhar desde o estudo preliminar, consegue participar, já com mais familiaridade na leitura destes desenhos: plantas mais elaboradas e até cortes técnicos (desenhos de níveis mais abstratos). As perspectivas, de abstração bastante baixa, vão se escasseando nesta fase.

Toda elaboração gráfica, pertencente a qualquer fase do processo do projeto arquitetônico, reflete os dotes de claridade, de exatidão, de geometrização e de construtibilidade implícitas em toda concepção arquitetônica, mas na medida variável e sempre maior quanto mais se aproxima da fase executiva da obra. ${ }^{3}$

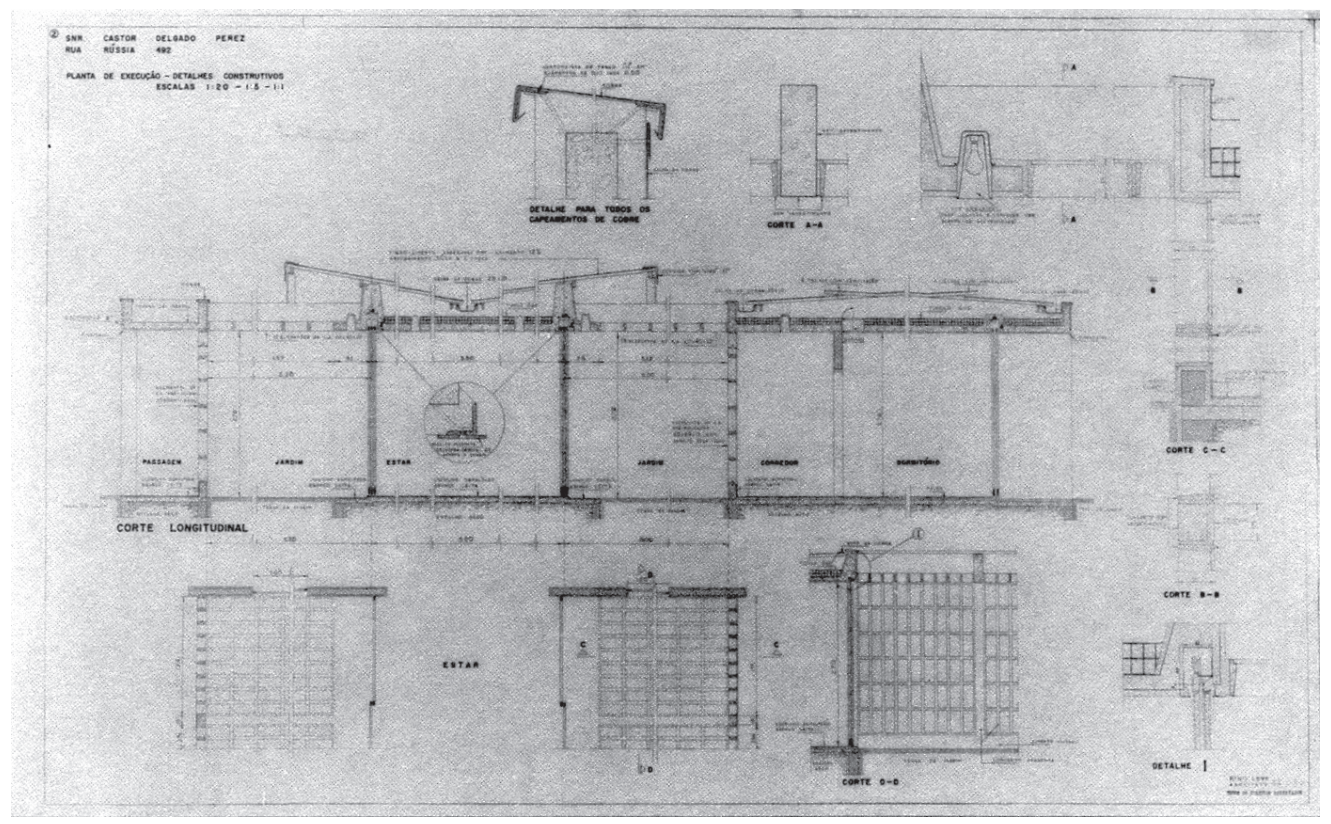

Uma vez aprovado o Anteprojeto, os desenhos de arquitetura são elaborados com uma codificação mais apurada e extremamente especializada e seguem para outros destinatários (também especializados): calculista de estrutura e outros projetistas complementares, além do orçamentista, engenheiro ou empreiteiro de obras. É o Projeto Executivo de arquitetura; estão em jogo, agora, os atributos e qualidades de clareza, viabilidade, inteligibilidade,
${ }^{3}$ Enciclopédia italiana de ciência, letras e arte. Instituto Giovanni Treccanti. Milão, 192938, vol.XIII, p.13-16, in SAINZ (1990, p.70).

Fig.[1] 9

Rino Levi, Roberto Cerqueira Cesar, Luiz Roberto Carvalho Franco. Casa Castor Delgado Pérez, 1958. Desenho executivo. 


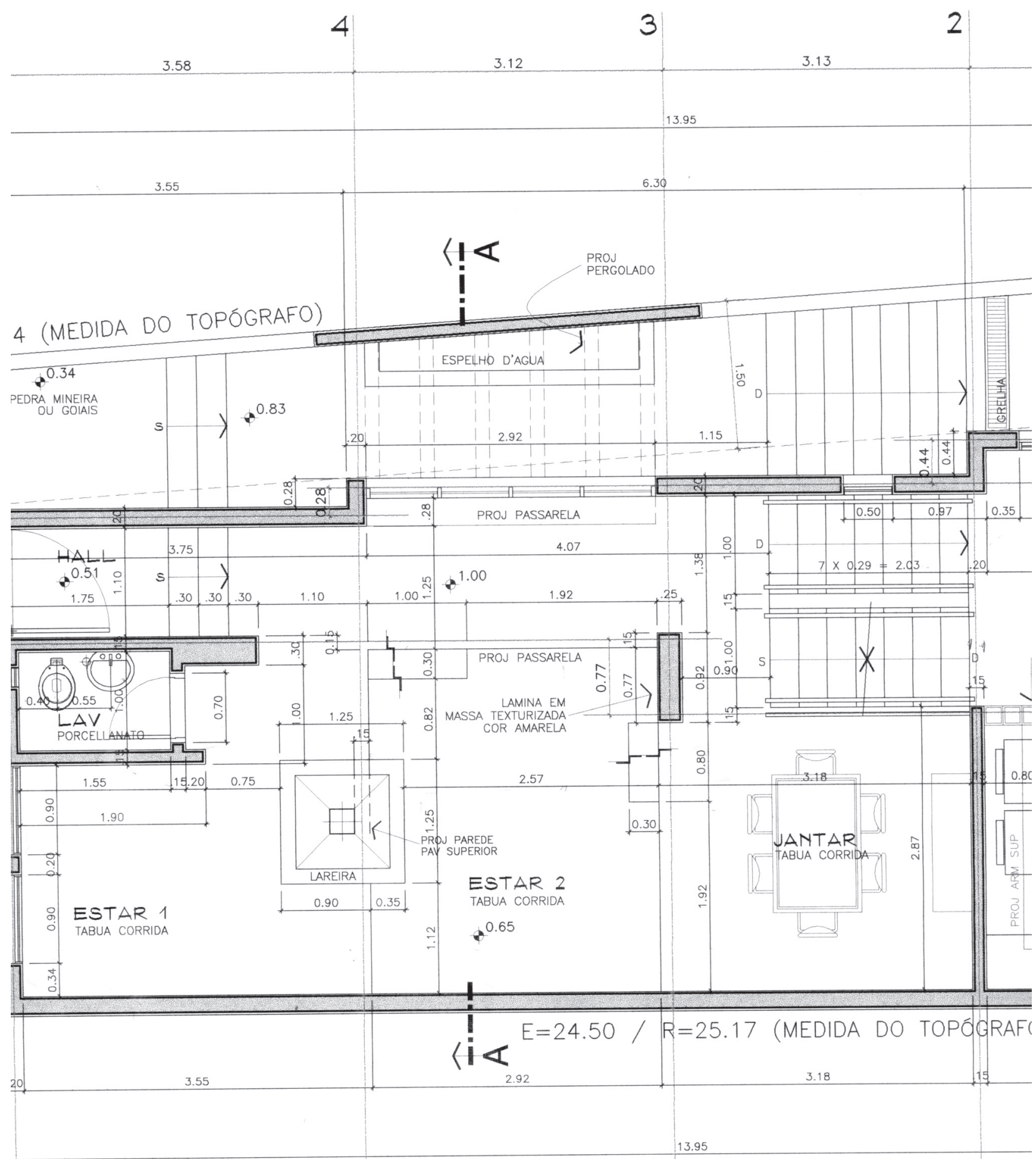
PLLANTA PAV TERREO

Fig.[1] 10 Heverson A. Tamashiro e Letícia Barreto da Cunha. Residência MA\&A, São Paulo, 1998. objetividade, quantificação, custos e o desejo de acertar. Nestes desenhos evita-se o equívoco, a interpretação dúbia. Novamente aparecem, com mais propriedade, as plantas, vistas, secções, inundadas de medidas ou cotas e especificações, que geram, organizadamente, novos desenhos, mais detalhados, em escalas diversas etc., num grau de complexidade tal que é menos 
familiar (ou até estranho) ao cliente contratante. Servem de suporte, desta vez, para outros profissionais trabalharem neles, cada qual com as suas especificidades (projeto elétrico, hidráulico, paisagismo etc.). Os desenhos técnicos arquitetônicos devem ser, neste momento, eficazes na comunicação com os agentes executores da obra. São estes desenhos e não outros que, efetivamente, concretizam as idéias e objetos propostos pelos arquitetos, na forma de obra construída.

No projeto executivo, por exemplo, as cotas são promovidas a um patamar de importância sem igual. Reivindicam para si, de imediato, toda precisão possível. Descrevem as medidas e a localização dos elementos característicos dos objetos arquitetônicos. Até então, as medidas podiam ser aproximadas ou nem se faziam presentes senão em alguns momentos estratégicos; agora, assumem missão de responsabilidade, de projeto-obra-construção real, em que estão envolvidos outros profissionais, o cliente, ... enfim, os custos. Organizações de padronização prescrevem, com exatidão, como devem ser apresentadas as cotas e as regras genéricas para sua seleção e colocação no desenho, mas "é necessário se ter habilidade para cotar os desenhos de modo que sua interpretação seja clara e não ambígua" (GIESECKE, 2002, p.259). A localização lógica das cotas, de acordo com as práticas recomendadas, faz com que sejam legíveis, fáceis de encontrar e interpretar. É preciso guarnecer o projeto de cotas suficientes, de maneira que não seja necessário tomar medidas do desenho ou pressupor alguma medida. As cotas não devem ser duplicadas ou supérfluas e devem ser fornecidas cotas funcionais - "cota essencial para a função do objeto ou local" ${ }^{4}$-, que orientará na perfeita viabilização de um projeto, ou detalhe deste, de acordo com a intenção do arquiteto.

Igualmente importantes e necessários são os textos que complementam os desenhos. Os textos de especificações de materiais, chamadas de detalhes etc. devem se apresentar, estrategicamente, nos documentos de desenho executivo, no momento certo, para os destinatários certos. Existe uma "comunicação interna" entre os desenhos, que são as chamadas de detalhes e seu correto endereçamento. Por exemplo, corte AA, na folha 12; ou, detalhe tal, na folha 17. Desenhos, textos ou cotas apresentados "fora de hora" ou para destinatários errados se apresentam como ruídos, mais atrapalham do que garantem a perfeita execução da obra, à vez de cada profissional: serralheria, marcenaria, gesso, instaladores diversos etc.

Desenhos de alteração de projeto - já com a obra em andamento - ou de ampliação fazem parte dos documentos gráficos do projeto executivo, anulando e substituindo desenhos anteriores. Há também desenhos "as built", que atualizam as modificações ocorridas em obra (sempre existem) ou documentam,
${ }^{4}$ Norma ABNT NBR 10126, Nov 1987 - Cotagem em desenho técnico. 
por exemplo, onde estão passando tubulações de intalações elétricas e hidráulicas nas paredes e pisos, com certo grau de precisão. Servem para facilitar posteriores reformas, facilitando o trabalho dos profissionais envolvidos.

Vagnetti - afirma SAINZ -, não renega a capacidade expressiva do desenho arquitetônico, mas não a considera uma qualidade desejável na documentação de projeto. Estimula a busca do desenho bom, em vez de belo:

É necessário chegar a uma ampla convicção sobre a função exata do desenho de arquitetura, de modo que estimule a busca do desenho bom, em vez do desenho belo, entendendo por bom um plano arquitetônico claro, eficaz, preciso e funcional. Um plano, em outros termos, que seja verdadeiramente descritivo, com o grau de capacidade descritiva necessário para cada fase do processo criativo que representa, e que evite sempre incursões veleidosas no setor que não é de sua competência (VAGNETTI apud SAINZ, 1990, p.70-71).

O desenho arquitetônico, nessas três clássicas etapas do processo de projeto - estudo preliminar, anteprojeto e projeto executivo - apresenta-se em graus diferentes de codificação: diferentes desenhos e convenções para destinatários diferentes. Existe também o desenho legal - dirigido às instâncias administrativas, para aprovação em órgãos públicos - elaborado antes ou paralelamente ao início do projeto executivo.

Há, ainda, outros tipos de desenho de arquitetura. O levantamento arquitetônico, escreve SAINZ (1990, p.88-90), é outro dos grandes temas de desenho de arquitetura: o de conservar uma completa documentação gráfica dos edifícios considerados de interesse arquitetônico ou histórico. Trata-se de uma finalidade primordialmente documental, juntamente com a fotografia.

O desenho é parte da própria essência da arquitetura, e sem ela a evolução da arte de construir haveria sido muito problemática. Por tudo isto, o desenho tem sido utilizado - e continua sendo - como apoio e ilustração de pensamentos críticos, teóricos e históricos relacionados com a arquitetura:

Desde o primeiro tratado conhecido até o mais recente livro de crítica arquitetônica, os profissionais se servem de desenhos existentes ou realizados ex profeso para aclarar suas idéias ou posturas ante um determinado tema. Isto é importante porque [...] somente a partir de uma documentação gráfica com um alto grau de fidelidade se podem realizar análises de todo tipo que possam aportar algumas conclusões certas. Muitos dos erros teóricos da história da arquitetura se devem a que as hipóteses se confirmaram somente à base de uma inspeção visual (SAINZ, 1990, p.95 e 101). 
Há, também, os desenhos de tipo visionário, que fornecem subsídio intelectual à arquitetura. Vittorio Magnago Lampugnani, em Dibujos y textos de la arquitectura del siglo XX: Utopia y realidad, apresenta edifícios que "fazem" história, através de desenhos de arquitetos. Justifica-se:

A decisão a favor do desenho elimina a diferença entre o executado e o não executado. [...] Ao poder plasmar no desenho idéias arquitetônicas com absoluta fidelidade, é possível salvar muito do que em outro caso se fundiria no consumismo de arquitetura. Isto é importante, porque freqüentemente há "arquiteturas de arquivo" que artística e historicamente são tão significativas como aquela que se constrói. Os exemplos que o ilustram são numerosos: desde o Monumento a Newton, de Etienne Louis Boullée, passando pelos projetos mais recentes de arranha-céus de vidro de Mies van der Rohe, até chegar ao Monumento Contínuo de Superstudio. Nos projetos desenhados, além de qualquer coerção imposta pela realização, que avança com audácia na utopia, é onde a idéia se manifesta com maior intensidade. A criatividade se manisfesta em sua forma mais pura; as visões, desembaraçadas de compromissos, se desenvolvem com liberdade: aparentemente desprendidos da realidade, são eles que, com seus impulsos incitantes, mais contribuem para mudá-la.

A isto se soma que, a partir dos desenhos de arquitetura, freqüentemente se pode identificar claramente a gênese de um projeto. A idéia básica deixa seu rastro sobre o papel, e rara é a vez em que as subseqüentes fases de elaboração não ficam visíveis ao modo de camadas superpostas. O processo criativo se decifra como uma formação geológica.

Por último, os desenhos de arquitetura podem ser indubitavelmente mais expressivos que a arquitetura edificada. A técnica, o modo de representação, o fragmento, o formato, o traço, tudo ilustra a intenção intelectual do autor. Desenhos com temas arquitetônicos são, portanto, manifestações tão aparentes como exatas de posturas culturais, que inclusive cobram um pouco do valor artístico e podem ser consideradas obras autônomas.

Obras autônomas no corpo disciplinário da arquitetura são projetos que foram desenhados e posteriomente realizados em forma de edifícios; são projetos concebidos para serem construídos, mas por uma ou outra razão não puderam ser realizados; também o são, por último, projetos que nasceram de antemão com a consciência de que não eram realizáveis, mas que estavam destinados a render aporte intelectual à arquitetura - e que eram capazes disso -, como as visões de Città Nuova, de Antonio Sant'Elia (LAMPUGNANI, 1983, p.6).

O conjunto de caprichos, vistas irreais, construções fantásticas, etc. teve um momento estelar na segunda metade do sec XVIII, especialmente nas obras de Piranesi e Boullée, arquitetos que praticamente não construíram, mas cujas 
Fig.[1] 11

Wassili Luckhardt. Cristal on the Sphere, 1920. Projeto para um edifício religioso (segunda versão); lápis de

cera.
Fig.[1] 12

Antonio Sant' Elia. Assinado e inscrito " La Città Nuova, detail" 1914. Musei Civici, Como.

Fig.[1] 13 Mies van der Rohe. Edifício de escritórios na

Friedrichstrasse, Berlin, 1919. Carvão e lápis.
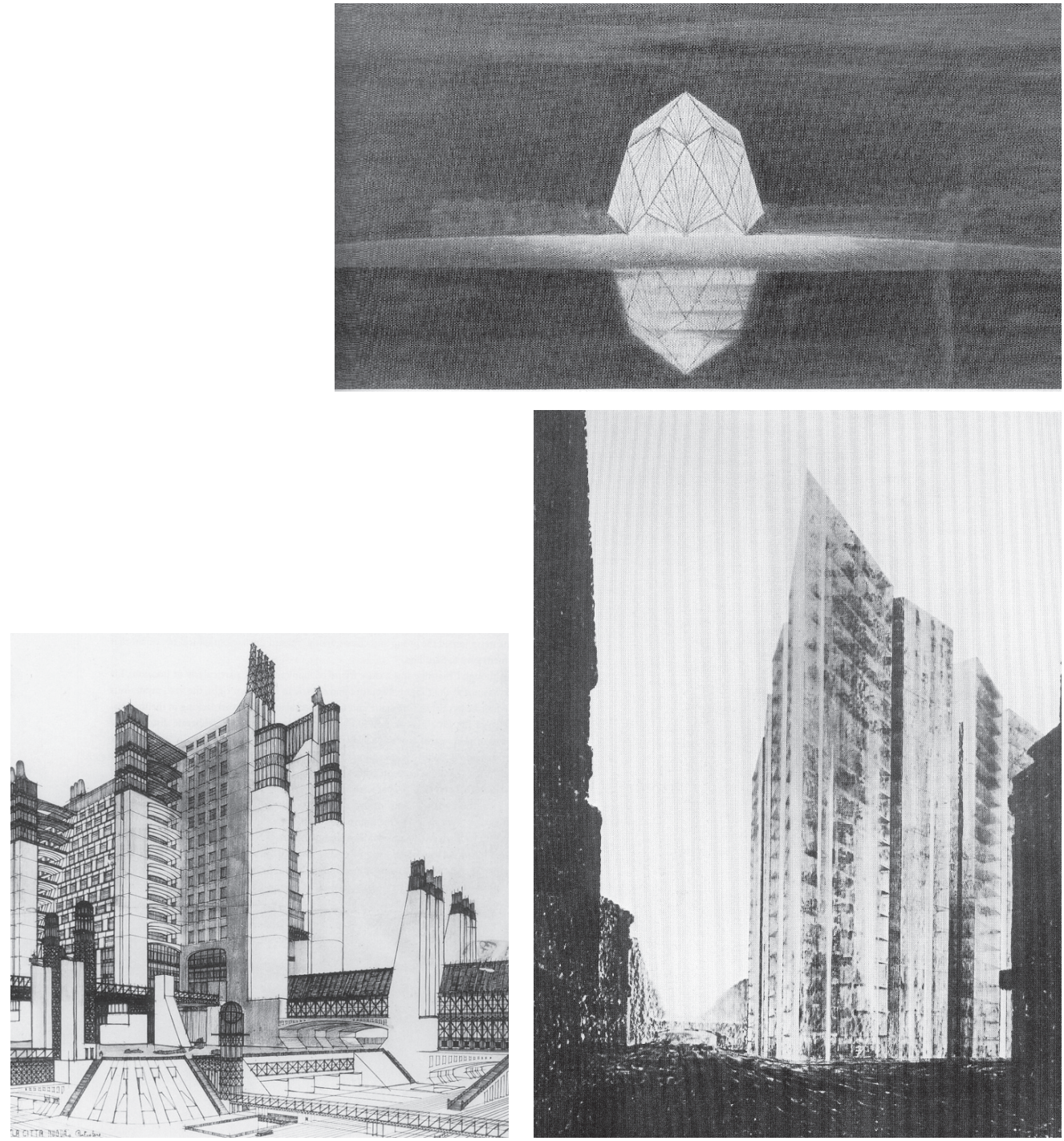

arquiteturas desenhadas tiveram uma formidável influência na evolução das futuras concepções arquitetônicas (SAINZ, 1990, p.106).

Um grupo de desenhos, da categoria de pura arte, a que MARTINS e VÁSQUEZ y RAMOS (1995) chamam de "arquiteturas de papel" - supõe um aporte à arte gráfica ou pictórica. Esses desenhos apresentam-se como sucedâneos "artísticos" das obras de arquitetura, constituindo o seu próprio circuito de colecionadores no mercado de arte. Fernando Vázquez y Ramos cita que:

[...] Não obstante, esta artisticidade é falaciosa, pois se caracteriza por uma intencionalidade reprimida, que se fundamenta na eliminação do objeto final, construção de uma possibilidade real de mundo. $O$ desenho que escapa intencionalmente ao ciclo projetual e produtivo da arquitetura como construção, imediatamente adquire "para-si" a falta de intencionalidade como suporte e se assume, então, como objeto artístico "em-si", independente de sua relação com a arquitetura (VÁSQUEZ y RAMOS in SAHM, 1995). 
FIALHO resume a classificação que PERRONE (1993, p.28-34) faz dos tipos de desenho:

O desenho comparece na gênese da arquitetura, em sua concepção, e pode, enquanto meio de comunicação, transmitir as informações para a sua realização, comparecendo em sua edificação. Estas duas funções delimitam, num quadro geral, as duas características principais do desenho de arquitetura.

1. desenho de arquitetura de caráter representativo/sugestivo, onde a finalidade é a de apresentar o ideário, gerir e apresentar a proposição de um projeto.

2. desenho de arquitetura de caráter descritivo/operativo, onde a finalidade principal é a de indicar as operações, as dimensões, os materiais, etc. para a execução da obra de arquitetura.

Desenhos sugestivos/representativos:

1. Desenhos de finalidade gnosiológica/metodológica: registros gráficos utilizados para a concepção e desenvolvimento de um projeto. Neste grupo estariam classificados os desenhos de estudos ou croquis que integram o método de trabalho do arquiteto, buscando tornar visíveis ao autor as possbilidades arquitetônicas colocadas em jogo e são tratados de maneira pessoal e livre; e os esquemas ou diagramas, que configuram representações nãoicônicas da arquitetura, produzidas para organizar dados referentes ao edifício.

2. Desenhos de finalidade comunicativa: registros gráficos do projeto que se concentram em traduzir os elementos principais da obra a ser construída. Neste grupo estão: desenhos de apresentação - executados para expor um projeto e destinados a indicar aos receptores pretendidos as características de um projeto, descrevendo-o através de plantas, cortes, elevações, e ilustrando-o através de perpectivas ou desenhos de fachadas; desenhos de memoriais ou explicativos - apresentam de forma analítica e sintética vários aspectos da obra construída, e não necessariamente antecedem a obra, podendo ser posteriores, para fins de comunicação, registro ou publicação; desenhos para vendas - buscam a transformação da obra arquitetônica num conjunto de valores identificáveis por um determinado público (perspectivas comerciais ou ilustração artística do projeto).

3. Desenhos de finalidade cognitiva: utilizados pelos arquitetos para o conhecimento de outras obras e elementos de arquitetura. Neste grupo, podemos incluir desenhos de documentação e reconstituição, que são o registro da memória arquitetônica; e desenhos de tratados, que atuam como guias para elaboração de outros projetos, que apresentam atributos visíveis que permitem caracterizar uma classificação morfológica, ou catalogar em tipos funcionais.

4. Desenhos de finalidade prospectiva: sem a finalidade de se tornar realizáveis, apresentam novas propostas arquitetônicas. Neste grupo podemos catalogar os desenhos fantásticos ou vi- 
sionários, de função ilustrativa, que não têm obrigação com o uso ou exeqüibilidade da obra.

Desenhos descritivos/operativos:

1. Desenhos para obras: destinados à execução, constituem elementos gráficos simbólicos e codificados. Desenhos intermediários para vários técnicos de diversos projetos que se articulam com o projeto de arquitetura. Neste grupo estão os desenhos de execução, que têm a finaliade de indicar as operações construtivas e assegurar a recomposição das informações em linguagem bidimensional para formas tridimensionais, seguindo normas precisas de desenho técnico e destinando-se aos técnicos, mestres, operários e artesãos da obra; e desenhos de detalhes, destinados à compreensão dos pormenores do projeto ou da obra a ser construída.

2. Desenhos de instrumentação: são destinados a facilitar o desenvolvimento do projeto executivo, apresentando soluções técnicas padronizadas para a utilização de materiais e componentes na obra. Neste grupo temos os desenhos de componentes, que representam peças isoladas de um dos subsistemas construtivos a partir do qual se construirá a obra; e desenhos de manuais elaborados para apresentar um conjunto de soluções técnicas para os detalhes executivos.

A tipologia apresentada não impede que os desenhos sejam utilizados de modo diferente em relação ao qual foram concebidos. Assim, podem ser utilizados desenhos documentais para fins representativos e vice-versa. Entretanto, além de reforçar as intenções entre desenho e arquitetura, tais fatos não invalidam a classificação apresentada - apenas indicam o cuidado com que se deve aplicá-la (FIALHO, 2002, p.18-19).

Em cada tipo de desenho, felizmente, cada arquiteto tem uma forma de expressar-se, tendo em conta sua formação, seu repertório, seu modo próprio de representação gráfica. Esta capacidade há de ser múltipla e variada, como o é a própria arquitetura.

Por outro lado, é preciso citar também que, segundo SAINZ, a qualidade gráfica de um desenho não implica a qualidade arquitetônica do edifício representado e vice-versa:

Uma arquitetura carente de qualidade pode ser representada de modo atrativo, e assim o desenho contribuiu para enriquecer sua imagem. Um edifício de grande qualidade arquitetônica pode ser desenhado de maneira não tão agradável, e então o desenho - além de não ser muito bonito - terá fracassado em sua missão de dar uma imagem o mais aproximada possível da arquitetura que representa (SAINZ, 1994, p.79). 
Escreve, ainda, que há claras diferenças entre um estilo gráfico e o que tradicionalmente tem sido considerado como um estilo arquitetônico. Essa reflexão costuma ser colocada como hipótese, como afirma Luís Moya:

Existe uma relação entre cada estilo de arquitetura e o desenho que a representa, uma relação que pode ser comprovada estudando-se os desenhos de arquitetura gótica tardia, os desenhos da Renascença e barroco, os neoclássicos e aqueles que ocorrem até hoje" (MOYA apud SAINZ, 1994, p.81).

O amadurecimento dessa afirmativa requer mais reflexão, necessitando de estudos mais aprofundados. "[...] Entretanto - afirma SAINZ - parece-nos mais natural supor que o desenho e a arquitetura seguem caminhos paralelos, como dois fatos culturais diferenciados, e que tiveram várias e múltiplas influências mútuas [...]" (SAINZ, 1994, p.82).

Os atributos gráficos, estudados por SAINZ (1990, p.61-75), como utilidade, beleza, durabilidade, veracidade, personalidade, precisão, fidelidade, expressividade etc., apesar de importantes e pertinentes, fogem ao âmbito deste trabalho.

\section{O desenho como comunicação}

O desenho se constitui no meio de expressão e comunicação mais utilizado pelos arquitetos. Ao simbolizar figurativamente os processos mentais desenvolvidos pelos arquitetos durante a concepção/criação do projeto, a linguagem gráfica desempenha uma função eminentemente comunicativa.

A denominação de linguagem, dada às manifestações elaboradas graficamente, é relativamente recente e provém da aplicação das leis de linguística estabelecidas pelo linguista Ferdinand Saussure, em Genebra, e por Charles Sanders Peirce, físico, filósofo, matemático e lógico, nos Estados Unidos, nos seus estudos de Semiótica e Semiologia (TURIN, 1994).

É condição primordial que o arquiteto faça a adequação do tipo de linguagem ao conteúdo da informação a ser comunicada. Imaginemos quantas palavras e gestos seriam necessários para explicar um projeto urbano ou a pretendida implantação de um edifício num terreno de acentuado declive. 
A capacidade comunicativa da linguagem gráfica no trabalho projetivo depende de alguns aspectos básicos: as condições dos sujeitos que emitem e recebem as mensagens gráficas, os códigos de leitura e os tipos de informação espacial que estão sendo comunicados no desenho (SCHUNCK, 1999, p.55).

Os emissores das mensagens gráficas são os arquitetos ou desenhistas; os receptores são os clientes, a comunidade, construtores, calculistas etc. São os sujeitos da ação da transmissão das idéias através do desenho. É importante lembrar - salienta SCHUNCK - que o sujeito que produz as representações gráficas espaciais não objetiva apenas a comunicação das mesmas para os respectivos agentes receptores, mas utiliza-as como forma de diálogo consigo mesmo ao longo de todo o processo de criação do projeto.

A atenção ao código faz-se necessária, pois os protagonistas envolvidos possuem graus diferentes de leitura da linguagem gráfica. Segundo Guiraud (1983) - afirma SCHUNCK - o código é um sistema de convenções explícitas que permite aproximações dos conteúdos da realidade, por meio de sinais reunidos por um indivíduo ou grupo social. Quanto mais aberto é o código, menor a necessidade de uma aprendizagem sistemática, e mais acessível é a sua leitura. Quanto mais fechado é o código, mais especializada e técnica é a linguagem. Sua leitura exige um conhecimento das chaves de decodificação e abrange grupos sociais específicos.

Yves Deforge (1981, p.12), em seu livro Le graphisme technique. Son histoire et son enseignement, trata particularmente das circunstâncias da comunicação entre os conceptores e os realizadores de um objeto material e dos modos de comunicação utilizados. Na introdução, escreve:

Se o conceptor não é o realizador, deve-se comunicar a este as informações necessárias e suficientes para a realização de seu projeto. O meio de ensino se faz sempre em vista de uma ação a cumprir e requer a presença de um pré-requisito de competências tecnológicas relativas à área ensinada; a comunicação é função do estatuto dos dois protagonistas. Quanto mais competente for o realizador, menos o conceptor tem de entrar em detalhes. Pelo contrário, se o conceptor duvida das competências do realizador ou as negligencia e tem ele próprio as competências do campo, ele vai multiplicar as informações em prol do realizador, a ponto mesmo de lhe ditar todos os detalhes do seu trabalho e a ordem pela qual ele o deve executar. Por sua vez, o conceptor deve ter o cuidado de adotar um modo de apresentação adaptado às circunstâncias da comunicação, desde o croqui até à ordem programada.

E continua: 
[...] 0 modo de apresentação das informações deve então permitir ao conceptor criar e modificar as formas, definir e especificar, conservar e reproduzir os resultados de seus estudos. Já o realizador, por sua vez, deve ter fácil acesso às informações que lhe dizem respeito sem ter de efetuar pesquisas e de decifrar codificações extenuantes. Na medida que eles respondem a essas condições, todos os modos de apresentação: figurativos, semi-figurativos, simbólicos; e todas as matérias: maquetes, desenhos, esquemas, gráficos, modelos matemáticos, símbolos e escrituras, palavras e gestos são aceitáveis. [...] Nesse meio, o desenho tem um lugar preponderante. Isso é devido a um certo número de características favoráveis à comunicação, mais ou menos específicas, que se sobressaem quando se analisa o conteúdo e a função do desenho técnico. Em primeira análise, é evidente que o desenho não é somente uma imagem. É um projeto, um "propósito", que o conceptor exprime sobre uma superfície plana (geralmente uma folha de papel) através de desenhos, de símbolos, de cifras e de escritas que são os modos de apresentação das informações".

O desenho, na forma de documento de projeto para obra, com suas informações de textos, medidas etc. deve ser objetivo, claro, conciso, sem ser lacônico, sem possibilitar interpretações duvidosas. Nesses desenhos, o profissional deve evitar os equívocos. Aqui entra o bom senso, fruto da experiência de alguns anos, como salientou o arquiteto José Mário Nogueira. ${ }^{5}$

Deforge trata do desenho técnico e o citamos sem prejuízo ao nosso objeto de pesquisa, o desenho arquitetônico. Remetemos do desenho técnico as sistematizações e efetuamos as devidas adaptações, criando uma gramática própria e específica:

[...] o desenho técnico é portador de informações sobre as formas, as dimensões, a qualidade das superfícies, suas posições relativas e sobre "o estado civil" do produto acabado: denominação, materiais, origem, etc. As informações à disposição constituem uma espécie de memória morta. Todas as informações são co-presentes sobre a superfície desenhada, sem uma ordem preferencial imposta. Não há leitura linear mas sim consulta. Os processos de consulta dependem daquele que procura e daquilo que se consulta: é, segundo o caso, a função geral, a cadeia cinemática, os materiais constitutivos, as dimensões de obstáculo ou outras especificações; as informações ativadas têm relação com um universo de conceitos e de representações mentais limitadas àquilo que é necessário ao realizador dentro desse universo: aquele do corpo da função, da corporação, da fábrica, do domínio técnico, do momento também.[...] (DEFORGE, 1981, p. 13).

A eficácia e clareza da comunicação no ensino de projeto e, principalmente, o desenho nas escolas de arquitetura, são uma questão fundamental para se atribuir certa importância e atenção. A maioria dos alunos não sabem (ou nós, professores, não o transmitimos senão de maneira superficial e rápida),
5 Entrevista realizada pelo autor com o arquiteto José Mário Nogueira de Carvalho Jr., em 10/01/2003. Formado na FAU USP São Paulo em 1972, além de professor na área de desenho e projeto na Universidade Federal de São Carlos, é arquiteto atuante na cidade e apresenta seus projetos com desenhos executivos e $x$ e $\mathrm{m} \mathrm{plarmente}$ elaborados. 
através dos seus desenhos, comunicarem, numa seqüência lógica, suas idéias e propostas de projeto. Em geral, desde a inexpressividade do desenho (tão comum pela falta cada vez maior de horas-aula de desenho) e apresentação dos espaços sem encará-los a fundo nos seus detalhes, até as searas operacionais do desenho como comunicação (escalas, textos, diagramas gráficos, chamadas de detalhes etc.), os alunos vão caminhando para o final do curso e saem, para o mercado, com deficiências que, antigamente, eram menos recorrentes.

Partindo da prerrogativa do desenho como comunicação, como linguagem do arquiteto, faz-se necessário resgatar este assunto da comunicação na sua melhor forma e, de algum modo, adaptando-se a mecanismos mais contemporâneos de ensino, transmitir esta idéia aos alunos com mais relevância e apresentando, na prática, casos exemplares de desenhos ou conjunto de desenhos que, efetivamente, deram conta do recado de transmitir, comunicar uma idéia.

Pode-se esclarecer aos alunos, por exemplo, que a elaboração de seus desenhos é comparável à de uma redação, pois deve ter começo, meio e fim, numa seqüência natural e lógica, em que esses desenhos possam falar por si, serem auto-explicativos, de tal forma que não precisem estar presentes para explanar suas idéias (como num concurso ou numa mostra em que não estarão presentes seus autores, pelo menos o tempo todo, todos os dias). A exposição clara, objetiva e concisa das idéias, através de desenhos e textos, deve ser num crescendo tal, que estes vão do geral para o particular, manifestando, cada qual a seu modo, os levantamentos, leituras e diagnósticos de um problema ou demanda e a conseqüente proposta arquitetônica de seu projeto. Textos, diagramas gráficos, esquemas, perspectivas, além das plantas, cortes e vistas, devem estar estrategicamente presentes, na oportunidade certa, dentro da exposição geral; em escala adequada, com as simbologias e códigos pertinentes, tendo em vista a busca da perfeita e eficaz comunicação com o receptor.

A linguagem gráfica arquitetônica - escreve SCHUNCK (1999, p.55) - acompanha e representa simbolicamente todo o processo projetivo, desde a descrição dos espaços reais, passando para o desenvolvimento de soluções possíveis para cada projeto e chegando, por fim, ao mais alto grau de definição geométrica e espacial. Ao longo desse processo, a representação gráfica desempenha múltiplas funções cognitivas. Em todas essas fases, ocorrem todos os tipos de desenhos e códigos, mas em cada uma delas, o desempenho comunicativo dos diferentes modos de representação e tipos gráficos tem características próprias. 
O CAD, fenômeno recente, de pouco mais de dez anos e que tem crescido progressivamente, principalmente com a queda do preço do computadores pessoais e conseqüente acessibilidade a todos, parece ser, indiretamente, um dos causadores do enfraquecimento ou empobrecimento do ensino e prática do desenho técnico arquitetônico. "Vilão" secundário, contribui para a homogeneização da representação gráfica do desenho técnico. Há pouco tempo, os escritórios de arquitetura procuravam estagiários e projetistas que possuíam a prática do bom desenho. Hoje, procuram-se "cadistas". Aqui, porém, há também um novo e vasto campo a explorar, das peculiaridades próprias desta nova ferramenta. Dentre os cadistas de desenho arquitetônico, existem, também, os que sabem e os que pensam que sabem, os bons e os ruins (não que o profissional seja ruim, mas o uso da técnica não está adequado). 0 que nos preocupa, e é importante, é que há cadistas que pouco sabem sobre o vocabulário mínimo de representação de desenho de arquitetura, razão pela qual usam o CAD como ferramenta. Precisam, antes, aprender bem o desenho arquitetônico, para melhor explorar as facilidades que o computador proporciona. Além disso, é possível, também, que os desenhos em CAD tenham expressividade e sejam bem apresentados.

Novos saberes e novos recursos foram inventados com a ferramenta CAD: o dos "layers", por exemplo, que são as camadas de desenho, em que podemos, convenientemente, visualizar ou não ("congelar") alguns elementos de desenho. Para gerenciar adequadamente esse comando, faz-se necessário saber desenho arquitetônico, entender uma construção, saber distingüir estrutura de fechamentos, instalações, mobiliário fixo e solto, revestimentos etc.

Em decorrência da popularização e do uso irreversível do CAD em desenhos de arquitetura, a AsBEA - Associação Brasileira de Escritórios de Arquitetura - promoveu recentemente um estudo no sentido de padronizar critérios e procedimentos de uso do CAD para representação de desenho técnico de arquitetura, a fim de garantir uma comunicação mais eficaz entre os profissionais da área. ${ }^{6}$ Isoladamente, essas precauções estão também acontecendo em pequenos escritórios de arquitetura: procurar-se padronizar principalmente os "layers", cores, espessuras etc.

Alguns recursos novos chegaram até a modificar os procedimentos das etapas de apresentação de um projeto, além de proporcionar visualizações de maquetes eletrônicas:

\author{
${ }^{6}$ Manual de \\ Diretrizes Gerais para \\ Intercambialidade \\ de Projetos em \\ CAD. Editado e \\ comercializado pela Pini, \\ a publicação é resultado \\ de mais de dois anos de \\ trabalho desenvolvido \\ por uma comissão \\ formada pelos arquitetos \\ Henrique Cambiaghi, \\ presidente da AsBEA; \\ Roberto Amá, diretor, \\ Miriam Castanho e \\ Marcelo Westermann. \\ Com base nas \\ normas internacionais \\ americanas/canadenses \\ (AIA, CSI, NBSI) e \\ européias (ISO e \\ BSI), o sistema de \\ padronização da AsBEA \\ propõe a uniformização \\ de diretórios, arquivos \\ e layers criando uma \\ linguagem única para \\ rastrear todo tipo de \\ informação relacionada \\ a projetos. Fonte: \\ http://www.asbea.org. \\ br/jornal/j77/index77. \\ htm, Informativo n.77, \\ outubro 2002.
}


Nos escritórios de Arquitetura, a invasão dos computadores foi realmente muito grande. $O$ abandono de algumas etapas na concepção dos projetos, do estudo preliminar ao projeto executivo, foi de grande valia para diminuir o tempo considerável no desenvolvimento projetual. [...] A ferramenta de simulação no computador, na área de Arquitetura, vem propiciando a sintetização de uma série de imagens e percursos do objeto arquitetônico antes impossível de se fazer. A simulação é o passo seguinte; com ela, conseguimos aplicar as variações aos modelos, colocando sob diferentes pontos de vista e diferentes possibilidades de condições "fisicas", as infinitas potencialidades do modelo virtual. Com isso, pretendemos entender a simulação das imagens sintéticas, não só como uma "teia" de imensas correlações e extrapolações que o objeto pode adquirir (GOMES, 2002, p.39).

Em consequiência, também, novas modalidades de erros surgiram. É o caso, por exemplo, em que as cotas "montam" sobre um texto, quando não são revistas atentamente. É inpensável que um desenhista, na prancheta, à mão ou com o normógrafo, pudesse cometer esse equívoco. Aliás, se não fossem os comandos de "voltar" (desfazer, "undo"), esse seria o modo mais rápido de errar. Um desenhista-projetista, na prancheta, ao se dar conta de que errou, começa a apagar (ou "raspar" com uma lâmina - "gilete" - o nanquim sobre o papel vegetal). Este processo leva tempo e, durante essa ação, o desenhista ainda reflete sobre o erro. Em CAD, esse processo tem outra velocidade e os programadores tiveram que solucionar essas "reflexões" sobre o erro, com comandos de "desfazer" e "refazer".

As cotas sobre desenho ou texto (desatenções na revisão) tornam-se ilegíveis, prejudicando a sua consulta.

Fig.[1] 14 Heverson A. Tamashiro e Letícia Barreto da Cunha. Residência H\&C, Bertioga, SP, 1998.

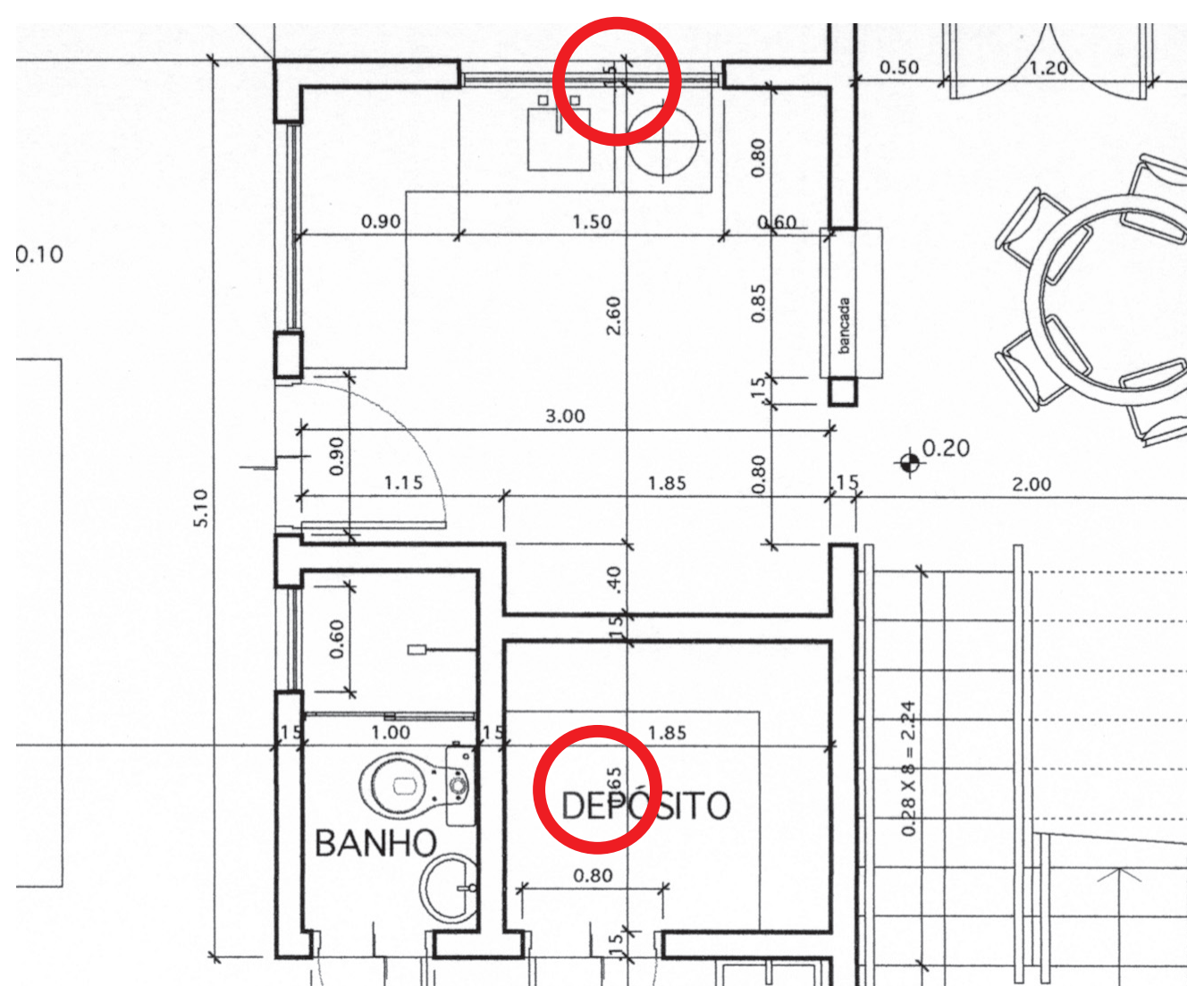


É um novo campo em que há muito a explorar, juntamente com as facilidades de comunicação, de trocas de informações em segundos. GOMES assim escreve:

\begin{abstract}
"Planificar o impacto das novas tecnologias informacionais na área da Arquitetura, prioritariamente voltada aos conceitos relacionados à representação gráfica, aparentemente é tarefa ainda muito pouco exercida por arquitetos, comunicadores e designers. A maneira recente como tem-se desenvolvido a recente produção científica no país, no âmbito da informação, e mais especificamente, com os reflexos das novas tecnologias da informação junto à Arquitetura, parece até agora ter gerado pouco volume de informação na área de representação gráfica. Por outro lado, a interatividade de todos os campos do conhecimento científico tem aberto caminho enorme de novas possibilidades de investigações" (GOMES, 2002, p.34).
\end{abstract}

Há autores, felizmente, preocupados em não perder os conceitos essenciais pelos quais utilizamos o computador. Um novo desenho, transformado sobre si mesmo, mais que substituir as "velhas" tecnologias pelas novas, como afirmam LA VEGA e RUIZ (2002, p.87), produz uma transformação da qual perdura o essencial, o conceitual. Os novos conhecimentos e as tecnologias não necessariamente eliminam o velho. Quando o "velho" se incorpora à cultura universal, então se aperfeiçoa, se transforma:

[...] São perguntas que, por muito que meditemos ou investiguemos em nossa própria história, no momento não podemos respondêlas de maneira convincente. Mas uma coisa, sim, podemos ter por certo: as tecnologias surgem e desaparecem, mas o ensino que se estabelece sobre bases conceituais, sobre invariantes do conhecimento, sempre estará preparado para assumir os novos câmbios e caminhamos sobre eles, como a aritmética que sobrevive à calculadora portátil, [...] (LA VEGA; RUIZ, 2002, p.87).

Yves DEFORGE, analisando os CAD/CAM, vai mais além ao comentar o que acontece quando o desenho técnico sai de cena para dar lugar a outros agentes:

Se nas fabricações mecânicas clássicas o desenho técnico tem um papel preponderante em dois processos técnicos: o processo de concepção e de construção e o processo de realização (fabricação, montagem, controle), nos dois casos, é o homem que adotou e adaptou esse mundo composto de expressão a seu próprio uso em função de uma estrutura de produção determinada. Mas quando o problema é tratado por computador e quando a informação de saída passa diretamente do computador para a máquina de produção de comando numérico sem necessitar do canal humano, o desenho técnico não é mais o mediador privilegiado (DEFORGE, 1981, p. 136). 
Os professores de arquitetura mostram-se cautelosos - uns mais, outros menos - quanto à melhor forma de se conduzir o ensino de CAD. Essas questões serão analisadas com mais profundidade quando analisarmos o questionário, um dos itens de procedimento desta pesquisa. Pode-se assegurar, no entanto, que a maioria prefere que seus alunos tenham, antes, uma boa prática em desenhos a mão e com instrumentos, na prancheta.

Além de conhecimento e muita prática de desenho à mão, buscando expressividade, técnica etc., um cadista de desenho arquitetônico deve ter, também, conhecimento do vocabulário de desenho arquitetônico: o que está em corte e o que está em vista, representações em diferentes pesos de espessuras de traço; simbologias; onde melhor cortar; lançamento adequado de eixos, a técnica de bem cotar ou dimensionar; como e quando especificar; como detalhar, como efetuar/estabelecer a perfeita comunicação entre os desenhos; em que escala desenhar esses detalhes; detalhá-los até que ponto; diferentes desenhos para diferentes destinatários etc.

O mais importante, entretanto, é ver o desenho arquitetônico como antecipação da obra executada ou a ser executada. Não se trata de desenhar uma linha pela linha em si, mas saber que cada linha ou conjunto delas é representação de algo real, construído ou a ser construído.

Além disso, é mais uma vez o desenho o meio de comunicação, seja com o cliente proprietário, seja com o construtor. É o suporte-desenho arquitetônico, em que se apresentam as medidas, cotas, especificações de material e quantidades, chamadas de detalhe etc. Nada mudou, somente a ferramenta de desenho. Assim, mantemos a essência - seja à mão ou no computador - do que é o desenho técnico arquitetônico. 


\section{Constataşão do atual ensino de Desenho Arquitetônico}

A discussão sobre o ensino de arquitetura nas escolas/faculdades do Brasil é um trabalho extenso e não é o objetivo desta pesquisa. Pretendemos, porém, estabelecer um foco de pesquisa bem específico, que diretamente proporcionará uma contribuição às aspirações de melhoria da qualidade do ensino de arquitetura que, neste caso, é na área de desenho e representação, mais precisamente no ensino do desenho técnico arquitetônico.

O que é fundamental transmitir aos alunos? É uma questão de padronização, de um conjunto de convenções e, portanto, que os alunos pesquisem e aprendam, por conta, nos mais variados livros e manuais de desenho técnico e/ou de desenho arquitetônico? Atualmente, é ou não necessário ensinar esta matéria? Hoje, é razoável que, não dispondo muitas escolas de carga horária suficiente para ensinar desenho arquitetônico, deixem de fazê-lo e até insinuem aos alunos, que procurem fazer esta matéria fora da escola, no mercado, já que se trata apenas de um punhado de convenções e normas?

Como e com que grau de qualidade desenham, hoje, os alunos? Assimilaram o aprendizado do desenho técnico arquitetônico e o põem em prática nas disciplinas de Projeto, reconhecendo-o como um dos modos da representação gráfica dos objetos da arquitetura? Nós, professores, atualizamo-nos para transmitir aos alunos os novos modos de desenhar em ferramentas eletrônicas, por exemplo? 


\section{Números desafiantes}

Existem hoje, aproximadamente, 152 escolas/faculdades de arquitetura no Brasil $^{1}$, das quais 28 se encontram em universidades públicas federais e 10, em públicas estaduais. Apenas três escolas se inserem numa universidade pública municipal. Somente no Estado de São Paulo contamos com 46, das quais 16 na Grande São Paulo, considerando-se as públicas e particulares.

Gogliardo Vieira Maragno escreveu um artigo sobre a quantidade e qualidade de novos cursos de arquitetura, por ocasião da IX CONABEA - Congresso Nacional da ABEA / XVI ENSEA - Encontro Nacional sobre Ensino de Arquitetura e Urbanismo. Cita que, no fim de 1999, eram conhecidos 108 cursos em funcionamento e pelo menos outros 12 com ingresso de alunos previsto para o semestre seguinte. Menciona ainda que estima-se que existam à época aproximadamente 30.000 estudantes de arquitetura com quase 3.500 concluintes por ano [MARAGNO, 1999]. ${ }^{2}$

Fizemos contato direto com ele, por correio eletrônico, e ele nos respondeu com números mais atualizados:

Segundo a publicação Sinopse Estatística da Educação Superior - 2001 (INEP 2002), no ano de 2001 havia 42.018 alunos matriculados nos cursos de arquitetura e urbanismo no Brasil, com 4.249 concluintes em 2000 e 5.133 concluintes em 2001.

Segundo o Relatório Síntese do Provão 2002 (INEP, 2002), 6.825 alunos foram inscritos para o Provão de 2002, realizado em junho do mesmo ano. Conforme a legislação, são inscritos no Provão os possíveis concluintes no ano de sua realização. Assim, em 2002, havia 6.825 estudantes com possibilidade de concluir seu curso nesse ano. Ainda não dispomos da comprovação dos reais concluintes de 2002 (MARAGNO, 2003).

MARAGNO inicia seu artigo (1999) com indagações que já devem ter passado por nossas mentes: "Quantos arquitetos e urbanistas existem hoje no Brasil? Quantos novos profissionais formam-se atualmente? Quantos são os estudantes de arquitetura e urbanismo no Brasil? Quantos cursos de arquitetura e urbanismo já estão em funcionamento? Há espaço para mais arquitetos e urbanistas? Para mais cursos?"
${ }^{1}$ Pesquisa realizada na página eletrônica: http://www.abea-arq.org. $\mathrm{br} /$. Última atualização: Janeiro/2003. "O número de cursos de Arquitetura e Urbanismo no Brasil vem sofrendo um aumento considerável nos últimos anos. A política da ABEA tem sido de procurar integrar todos os cursos existentes para uma ação coletiva que busque a qualidade crescente do ensino. Não há nenhum organismo oficial no Brasil que mantenha a listagem atualizada dos cursos em funcionamento, tendo em vista que o MEC mantém a lista apenas dos cursos reconhecidos. A ABEA vem procurando manter esta listagem atualizada [...]". ABEA - ASSOCIAÇÃO BRASILEIRA DE ENSINO DE ARQUITETURA E URBANISMO. Rua Fernando Ferrari, n. 75 Botafogo - Rio de Janeiro - RJ - CEP 22231-040 (junto à Univ. Santa Úrsula) / Fone: (21) 5535446 / E-mail: abea.arq. urb@uol.com.br. Data de acesso: 18.03.2003.

\footnotetext{
2 Maragno, Gogliardo Vieira. Abertura de novos cursos de arquitetura e Urbanismo: Uma questão de quantidade ou de qualidade?, in IX CONABEA - CONGRESSO NACIONAL DAABEA I XVI ENSEA -
} 
ENCONTRO NACIONAL SOBRE ENSINO DE ARQUITETURA E URBANISMO. 10 a 13 de novembro de 1999 - UEL - Londrina - PR. Artigo eletrônico extraído do Caderno n.21, na página eletrônica da ABEA (http://www.abea-arq. org.br/). Maragno ocupa, atualmente, o cargo de secretário de Finanças da ABEA e é professor no Departamento de Estruturas e Construção Civil da Universidade Federal do Mato Grosso do Sul. Também é membro da comissão de avaliação dos cursos de arquitetura e urbanismo do INEP/MEC.
Apresenta um panorama geral da crescente abertura de novos cursos:

Em 1920, prestes ao surgimento do movimento moderno das artes no Brasil, tínhamos 2 cursos de arquitetura, um no Rio de Janeiro (Escola Nacional de Belas Artes) e outro em São Paulo (Politécnica). Em 1933, ano do surgimento do primeiro instrumento nacional de regulamentação das profissões de engenheiro, arquiteto e agrimensor (Decreto 23.569) eram 4 cursos, acrescentando mais um em São Paulo (Mackenzie) e outro em Minas Gerais - o primeiro criado especificamente em uma Escola de Arquitetura. Passaramse 33 anos para atingirmos 12 cursos, em 1966, ano da atual lei de regulamentação profissional dos engenheiros, arquitetos $e$ agrônomos (Lei 5.194), distribuídos por 11 Estados (somente São Paulo contava com dois cursos). Bastaram 8 anos para este número crescer em 1974 para 28 cursos em 13 Estados, no ano que marca o nascimento da ABEA e início de funcionamento da CEAU. Houve um salto expressivo no número de cursos do Rio e de São Paulo, ambos com 7 cursos, além do Rio Grande do Sul, com 4. Os próximos 20 anos viram o surgimento de 44 cursos, totalizando, em 1994, no ano da Portaria 1.770 do MEC, 72 cursos em 19 Estados brasileiros, com aumento expressivo no Rio Grande do Sul, São Paulo e Minas, e com o Rio permanecendo com os mesmos 7 cursos. Finalmente, bastaram mais 5 anos para surgirem outros 36 cursos, distribuídos em 23 Estados, atingindo o número expressivo de 108 cursos em 1999. Somente Acre, Rondônia, Roraima e Amapá ainda não contam com curso de arquitetura e urbanismo. É inegável a aceleração na curva de criação de cursos (MARAGNO, 1999).

As indagações iniciais do texto de Maragno reproduzem antes de mais nada a angústia dos próprios arquitetos e urbanistas e dos estudantes sobre o futuro de sua profissão.

Estas preocupações - continua Maragno - são fruto de um mundo em veloz transformação, de um sentimento generalizado de estado de transição para uma nova ordem que não se compreende amplamente, que atemoriza e que desafia. Desafia profissionais e educadores a lançarem mão de sua capacidade criativa para um efetiva contribuição ao aprimoramento das relações humanas, do respeito aos direitos essenciais do homem, da preservação do planeta, da superação das desigualdades e preconceitos e da colaboração para o surgimento de uma sociedade mais justa no novo milênio [...]. Uma série de novas ordenações que são apresentadas ou vislumbradas em nossa área nos obrigam a um pensar e repensar sobre a educação e a atuação profissional (MARAGNO, 1999).

Maragno, mais adiante, sublinha que a política da ABEA, notadamente nesta última década, tem sido a de proporcionar, através de seus eventos, publicações e ações, a melhoria e o aperfeiçoamento de todos os cursos existentes e o conseqüente aumento da qualidade geral do ensino de arquitetura e urbanismo. Considera-se que ainda existam regiões carentes de cursos de 
arquitetura e urbanismo e outras já com quantidade expressiva, devendo ocorrer grande competição qualitativa entre eles, com alguns setores prevendo inclusive o fechamento daqueles que não forem capazes de acompanhar o nível de qualidade dos demais.

Algumas vozes - segue Maragno - têm falado da saturação do mercado profissional de arquitetura e urbanismo, ou da crise da profissão, sendo até mesmo possível sua extinção, para os mais pessimistas. Em resposta aos que imaginam que poderíamos estar diante de uma possível extinção do arquiteto, Sarquis, da Universidade de Buenos Aires, afirma que, com o crescimento das cidades e o agravamento das questões de moradia, saneamento, transporte, além das exigências culturais, será necessária cada vez mais a existência de profissionais para o atendimento destas demandas. $E$, não sendo o arquiteto este profissional, a sociedade precisaria inventar um outro com as características do próprio arquiteto, ou seja, reinventar um outro arquiteto. Citando livremente Borges, pergunta "a que homens foram reservados os tempos difíceis?" e responde que "a todos os homens e em todos os tempos" (Jorge Sarquis em exposição na mesa de trabalho "La profesión en la búsqueda de una arquitectura sustentable" por ocasião do Simpósio "La formación en Arquitectura hacia el siglo XXI"). Segundo a professora Maria Elisa Meira, "o domínio acumulado da arquitetura é que nos diferencia dos não-arquitetos, e o arquiteto tem assim a responsabilidade cultural e social de guardião do acervo construído pela humanidade, patrimônio coletivo a ser preservado como pilar fundamental da integridade cultural de cada uma das nações e suas gentes, como também a atribuição de intervir nos processos de renovação espacial das cidades, além de construir novas cidades". A professora Maria Elisa cita Benjamim: "(...) Mas a necessidade que os homens têm de habitar é permanente. A arquitetura jamais conheceu paralisações. Sua história é mais longa do que qualquer outra arte (...) (Benjamin, 1968:280)" (Maria Elisa Meira, "Patrimônio Cultural e Formação Profissional", trabalho enviado ao Seminário Nacional Critérios para Avaliação da Educação do Arquiteto e Urbanista, realizado pela ABEA em novembro de 1992 em Belo Horizonte). É preciso saber distinguir eventuais saturações do mercado de trabalho para aquele arquiteto projetista a que estávamos habituados, da extinção, ou mesmo diminuição de sua necessidade em auxiliar a sociedade nos crescentes problemas espaciais nas grandes, médias e pequenas aglomerações urbanas (MARAGNO, 1999).

Conclui Maragno que "a questão primordial não é, portanto, a quantidade numérica de cursos de arquitetura e urbanismo, mas sim a quantidade de cursos de arquitetura e urbanismo de qualidade, que atendam princípios, critérios e padrões que foram estabelecidos pela nossa própria área" (MARAGNO, 1999).

Esta pesquisa vai ao encontro destas preocupações, no sentido de procurar 
questionar o quadro atual do ensino na área de Representação e Linguagem, mais precisamente no ensino do desenho arquitetônico. Como se expressam, por meio do desenho, os possíveis 6800 arquitetos que "despejamos" no mercado? Como desenharão um projeto, que a partir de então - deixando as carteiras e seus trabalhos de projeto escolares - pretende efetivamente ser construído? Acreditamos que um bom desenho, correto, preciso, que seja o reflexo e registro das intenções do autor, tanto espacial como tecnicamente bem colocados, concorre, direta e indiretamente, para a qualidade da construção e da boa arquitetura, enfim.

\section{O desenho arquitetônico, sem "Desenho Arquitetônico"}

Costumamos ouvir alguns comentários de arquitetos e professores de Projeto, infelizmente em tom negativo e de queixa: "esses alunos não sabem desenhar" ou "os meus estagiários, até dos últimos anos de graduação, não sabem representar corretamente o desenho arquitetônico". Situação mais negativa ainda, grave e dura de ouvir é: "alguns nem sabem projetar". Queremos, entretanto, nesta pesquisa, atermo-nos somente ao desenho ou "não-desenho".

Pode acontecer, é triste, que um aluno não saiba - não procurou saber ou os professores não o instigaram a isso - como funciona, por exemplo, um determinado sistema estrutural ou de fechamento. Assim, tampouco sabe representá-lo através do desenho, nem esquematicamente. Logo, não o propõe em seu projeto. Parece-nos que, além do desenho arquitetônico em si, outras

${ }^{3}$ Entrevista com o arquiteto e professor aposentado Luiz Gastão de Castro e Lima, dia 20.11.2002, em sua residência, São CarlosSP. Gastão, nascido em 1927, formou-se na segunda turma da

Fau USP em 1954.

Foi professor na área de desenho nessa instituição e, mais tarde, no Departamento de Arquitetura e Urbanismo da EESC USP, onde participou da fundação da Pós-Graduação e da montagem, posteriormente, do curso da Graduação. implicações estão diretamente em jogo. Detectamos aí uma falha na condução do ensino, um filão a ser explorado desde as raízes.

O arquiteto Luiz Gastão de Castro e Lima [2002] comentou conosco sobre uma velha e sempre nova discussão: "os alunos não sabem desenhar!". ${ }^{3}$ Paradoxo do ensino, o disparate que carregamos conosco até hoje, pelo menos na FAU/ USP São Paulo e São Carlos. "Não sabem desenhar - continua ele - mas, nem aqui e nem na Fau USP havia, desde o início, uma disciplina que ensinasse explícita e diretamente a matéria do desenho arquitetônico." Os escritórios de arquitetura, segundo ele, "é que supriam essa deficiência ... Havia alunos que eram talentosos no desenho, como há na música; para esses não era preciso ensinar. E havia os que não sabiam desenhar. E para esses, era preciso dar as ferramentas básicas do desenho". 
Não poucas vezes, nos corredores do Departamento de Arquitetura da Escola de Engenharia de São Carlos/USP, onde somos docentes, professores de Projeto se queixam de que os alunos não sabem desenhar, não sabem representar o vocabulário mínimo dos procedimentos e convenções do desenho técnico arquitetônico, principalmente ao verificar os desenhos de projeto do último ano de muitos alunos.

$\mathrm{Na}$ Banca de Qualificação deste trabalho ${ }^{4}$, o professor José Jairo Sales, que compunha a mesa, comentou que, há pouco tempo, havia se encontrado com o arquiteto e professor Gastão e, dentre outras coisas, este assunto veio à tona, ao confirmar (o professor Gastão) sua posição de que os alunos não sabem desenhar. Imediatamente o professor Jairo apontou que a culpa é nossa, dos professores.

Há uma idéia - não arriscaríamos dizer que seja uma tese - defendida por alguns professores de Desenho e Projeto, de que é preciso ensinar os alunos a projetarem, formá-los arquitetos e não desenhistas: não é tão necessário ensinar o desenho! Bem entendido aqui, trata-se do desenho técnico arquitetônico. Este desenho técnico é para ser feito pelos técnicos (que fizeram curso técnico de edificações), projetistas, estagiários ..., e não pelo arquiteto. Outra idéia é que, o desenho arquitetônico é um conjunto de convenções, algumas normas e esse assunto se resolve em duas ou três aulas. Estas colocações em parte são corretas. No entanto, deve haver um equilíbrio: se o arquiteto não sabe representar, não é um arquiteto completo. 0 que não pode acontecer é a exacerbação dos inúmeros e intermináveis saberes da arquitetura, e o esquecimento, quase total, das habilidades do desenho e da técnica.

\section{A crise do "não-desenho"}

Em geral, as escolas/faculdades de arquitetura têm atribuído, atualmente, menos horas-aula e menos atenção ao desenho técnico arquitetônico. Algumas radicalizaram e abandonaram, de vez, uma disciplina que contemplasse esta matéria - talvez isto possa representar um problema. Outras, nunca tiveram uma disciplina própria para este assunto, como é o caso da FAU/USP, em São Paulo. Marcelo Suzuki, em entrevista, afirma que:

[...] Na FAU/USP São Paulo, não havia uma disciplina própria para o ensino de desenho arquitetônico. Eu não sei dizer de muito tempo antes ... No tempo do Artigas, na Poli, tinha desenho ... Eu não sei como se deu isso, de achar que já era fato consumado que os
${ }^{4}$ A Banca de Qualificação deste trabalho ocorreu no dia $22 / 01 / 2003$, no Departamento de Arquitetura e Urbanismo da EESC/USP, cuja mesa estava composta pelos professores Hugo Massaki Segawa e José Jairo Sales (professor convidado), além da professora orientadora. 
alunos aprendessem ao longo do curso, da projetação, a própria linguagem [...] Do projeto mesmo, projeto arquitetônico, os professores já contavam que você soubesse, ou que você aprendesse ao longo do curso, os colegas [...] que viesse aprendendo no processo. E quase nunca se perdia muito tempo nisso, ensinando a desenhar. Então, por exemplo, um projeto já seria muito mal atendido ou mal visto, se ele fosse mal desenhado, porque era um pressuposto

${ }^{5}$ Entrevistado em 03.04.2003. Marcelo Suzuki é arquiteto formado pala FAU/ USP São Paulo, em 1980, e professor do Departamento de Arquitetura e Urbanismo da EESC/ USP. que a gente já devia estar sabendo e fazendo (SUZUKI, 2003). ${ }^{5}$

Existem, infelizmente, escolas que não têm mesmo uma disciplina que ensine, direta ou indiretamente, a matéria de desenho arquitetônico. Os professores de Projeto é que assumem essa incumbência, tendo que dividir, heroicamente, seus esforços e tempo para tais tarefas. É o que nos escreveu, prestativamente, por correio eletrônico, uma professora, quando da aplicação do questionário:

"[...], mas eu sou responsável pela disciplina de Projeto arquitetônico. Se você achar que eu posso ajudar... me avise que responderei (ao questionário). Irei encaminhar para os professores responsáveis pela disciplina de infomática. Se você me permite um comentário, gostaria de dizer que: hoje, com a redução dos currículos, até o mínimo de 3.600 horas/aula permitido pelo MEC, quase não há, nas escolas particulares de nossa região, a manutenção destas disciplinas - somente há a instrumentalização por meio dos programas clássicos de desenho por computador. Os professores de projeto é que têm a responsabilidade de cobrar e, na medida da possibilidade, orientar sobre a representação das propostas - não se esqueça de que estamos falando de 4 horas/aula por semana em média para as disciplinas de projeto. E os alunos quase sempre fazem cursos de desenho fora da faculdade... mas isto tudo você já deve saber [...]" (V.B., 2002).

Historicamente, pelo menos na cidade de São Paulo, podemos remontar à prática do ensino de desenho arquitetônico na Escola Politécnica da USP-São Paulo, fundada em 1894. Esta, por sua vez, mais do que se basear na Ecole Polytechnique, fundada em Paris, em 1795, seguiu a escola alemã de Karlsruhe, fundada em 1825:

Na Politécnica seguiu-se bem mais o sistema germânico, o qual - apesar do fruto da difusão da experiência pioneira francesa ao longo do século XIX - tinha a particular característica de unificar o ensino fundamental e dos cursos especiais em uma única escola. Este havia sido o modelo adotado no Polytechnikum de Karlsrule em 1832 e prevalecera com algumas variações na organização do de Zurique em 1834. E foi adotado na Politécnica de São Paulo, muito provavelmente porque o seu principal organizador e primeiro diretor, Antonio Francisco de Paula Souza, havia estudado em Karlsruhe, onde se formara engenheiro civil em 1868 (FICHER, 1989, p.20). 
Aquarelas, perspectivas exatas, desenhos precisos com rigor técnico sem igual etc. perfaziam a condição da formação do engenheiro ou engenheiro-arquiteto até as primeiras décadas do século XX. Hoje, não se trata de manter todas estas posturas e exigências daquela época, pois novos modos de projetar arquitetura implicaram novos modos de representar: "... uma nova arquitetura, uma nova maneira de pensar, um novo repertório de formas" (SAHM, 1995).

No decorrer dos estudos da arquitetura e no atendimento às dinâmicas da sociedade, além do desenvolvimento de novas tecnologias e do surgimento de novos materiais, novos saberes se acrescentaram e/ou foram reivindicando espaços de carga horária no ensino das escolas de arquitetura. Talvez, nesse processo, as disciplinas de desenho tenham sido as que mais foram retaliadas.

O aumento das escolas técnicas, de ensino profissionalizante, principalmente os cursos técnicos de edificações, cumpriram o papel de formadores de bons projetistas e desenhistas. Isto deve ter causado, indiretamente, uma transferência de responsabilidades do ensino de desenho técnico arquitetônico a estas escolas.

A própria simplificação do desenho, a elaboração das normas técnicas de desenho6 ${ }^{6}$ a publicação de manuais de desenho arquitetônico, iniciativas bemvindas e necessárias, também foram aliadas que contribuíram para conferir menos importância ao ensino do desenho técnico arquitetônico.

O surgimento dos sistemas CAD também se alia a estes fatores, por um lado, pela homogeneização do desenho e, por outro, pelas customizações e bibliotecas prontas, facilidades próprias dessas ferramentas eletrônicas. Antes, os escritórios de arquitetura contratavam estagiários e alunos de arquitetura que realmente sabiam desenhar. Hoje, com o CAD, contratam quem tem certo domínio dessa ferramenta que, na maioria dos casos, não tem tanta prática do desenho à mão.

Um fato histórico que não podemos desconsiderar, é que os escritórios de arquitetura desempenhavam, enormemente, o papel de formadores de desenhistas (muitas vezes, também, de arquitetos), notadamente nas grandes cidades. Na entrevista, SUZUKI coloca:

[...] o traquejo mesmo vem é de escritório. Existe uma circunstância psicológica completamente diferente do aluno no atelier e do aluno no escritório, sendo seu estagiário, mesmo não sendo seu aluno, mas ele sendo estudante. E essa diferença de postura, vale para tudo, até para um estagiário ser bom e ir continuando com a

\footnotetext{
${ }^{6}$ Encontramos a reimpressão da Norma P-NB-43/1960

- Execução de desenho de arquitetura, em estágio experimental, no livro Associação Brasileira de Normas Técnicas: Normas para Desenho Técnico, organizado pelo Eng.

Paulo de Barros Ferlini (Porto Alegre: Globo; Rio de Janeiro: FENAME, 1981, p.248). Atualmente, está em vigor a Norma NBR 6492/1994

- Representação gráfica de projetos de arquitetura.
} 
gente; depois se forma, torna-se um dos nossos amigos; vai indo bem na profissão e a gente torce por ele etc. ... Em geral, eles, no escritório, já vão se imbuindo de questões muito mais rapidamente do que seriam capazes de fazer no atelier. Preocupam-se com prazos, com a precisão, com a quantidade de informações corretas ..., rapidamente pegam este clima no escritório. No atelier, por mais que você repita e ensine de novo, no semestre seguinte parece que o aluno esqueceu ... Eu acho que, em parte, é necessário o trabalho de escritório para todos, pelo menos da convivência entre a academia e os trabalhos de fora.

E continua:

[...] Os escritórios acabavam formando não só em desenho arquitetônico, mas até em linguagem informatizada, o CAD, por exemplo. A velocidade com que eles acabam pegando traquejo por estar operando no escritório não acontece na escola, assim como no nosso tempo de nanquim e acabamento, cruzamento de linha etc. ... Pegávamos isso no escritório e não na escola. Eu me lembro que a preocupação no escritório, de esmerar e de deixar um desenho limpo, correto, para que fosse elogiado pelo chefe, era sempre muito maior do que na escola.

[...] Na escola, o aluno se conforma, entre outras coisas, com aquilo que a gente chama de tempo para pensar e, no escritório, acaba sendo obrigado ..., acostumando-se com o prazo pré-estabelecido, não é o tempo para pensar, é o tempo para fazer. Isso diferencia muito a escola da realidade, no bom sentido [...] Então, é prioritário que, se você não fez uma maquete muito bem, mas o conteúdo de arquitetura proposto nessa maquete é bom, então está ótimo. Essa maquete não foi feita para ser apresentada, foi feita como um processo do seu pensamento, do seu saber construído ... a maquete está "mal", mas o projeto é bom. No escritório, você vai apresentar para o cliente, e leva uma maquete bem feita.

[...] leve um desenho bem feito, treine croqui, aprenda a fazer croquis na frente do seu cliente, ele se emociona quando vê isso, que você sabe. Às vezes a gente pega uns traquejos assim, ao longo da vida, que viram até truque. Por exemplo, desenhar a perspectiva explicativa de um assunto que você está conversado com o cliente, a perspectiva o tempo inteiro sendo desenhada na frente do cliente. Aí você o vê ficando embasbacado. Primeiro, porque entendeu; segundo, porque vai te respeitar um pouco mais ... Esse desenvolvimento tem que existir também ... São uma contradição, esses conteúdos.... todos são importantes, mas realmente esse conforto de desenhar, de se expressar com fluência ... eu acredito que só surge mesmo depois que a gente se faz profissional (SUZUKI, 2003).

Na apresentação do livro Racionalismo e Proto-Modernismo na obra de Victor Dubugras, Sylvia Ficher escreve sobre a formação desse arquiteto, reforçando a idéia do aprendizado em escritórios de arquitetura: 
A hipótese de que Dubugras não tenha tido formação institucional, para alguns derrogativa, pode ser entendida como uma lição positiva sobre a prática da arquitetura e seu ensino. Em fins do século passado a 'apprenticenship' ainda é o procedimento regular, 'natural', de acesso à profissão. Basta pensarmos no número ínfimo de escolas de arquitetura existentes no mundo ocidental e lembrar quão recente é a validade legal de nosso diploma, no Brasil regulamentado muito tempo depois, apenas em 1933, ano em que falecia Dubugras. E hoje reconhecemos - não sem alguma angústia - a importância dos estágios em escritórios ou firmas construtoras na formação de nossos alunos (FICHER in REIS FILHO, 1997, p.11).

E Abelardo de Souza menciona:

Nosso aprendizado não se limitava ao escritório; fazíamos, também, estágio nas obras, o que era um excelente exercício para a nossa profissão. Lá, nas obras, é que era possível avaliar a importância de um projeto bem estudado e detalhado no desenvolvimento de um serviço. O contato com a obra, ter de resolver no local qualquer dúvida que aparecesse, nos dava muita segurança e maior facilidade para a execução de melhores soluções e novos detalhes (SOUZA in XAVIER, 1987, p.64).

Acreditamos que pelo menos a FAU/USP São Paulo e as escolas sediadas em grandes centros urbanos se beneficiaram muito deste "auxílio" que os escritórios de arquitetura proporcionavam à formação de desenhistas e também de arquitetos.

Um fator, talvez cultural e ao mesmo tempo climático, no Brasil, é que, diferentemente dos países frios europeus e dos Estados Unidos - onde os detalhes exaustivos, para eles naturais, de fechamentos (paredes duplas com isolante térmico entre elas), cobertura etc., são cuidadosamente cotados em milímetros (ou polegadas e suas frações) -, usamos, ainda hoje, materiais primários (tijolo, por exemplo) e menos precisão. Assim, salvo complexos edifícios, os desenhos são despojados, simples e não teriam por que serem, em princípio, altamente detalhados. E a busca da precisão não estaria importando tanto.

$\mathrm{Na}$ Europa e nos Estados Unidos se falava em arquitetura em termos de concreto armado ou estrutura metálica, enquanto nós ainda pensávamos em paredes de tijolo e taipa (SOUZA in XAVIER, 1987, p.59).

Para além destes fatores, talvez o que mais pesa em todo esse processo de

"enfraquecimento", de um certo indiferentismo frente ao desenho técnico 
arquitetônico, seja o pensamento, acertado em termos, de que é preciso formar arquitetos, não desenhistas.

Assim, de todos os fatores mencionados, tem peso considerável uma nova postura do arquiteto. Givaldo Medeiros, arquiteto e professor, afirma que o arquiteto chama para si, a partir do final dos anos de 1960, novas atribuições, novas responsabilidades e fronteiras para ele mesmo agir, no contexto do Brasil em desenvolvimento, ligado à esfera do planejamento. Assim, o curso da FAU/USP São Paulo afasta-se do canteiro, da construção, do edifício e,

${ }^{7}$ Conversa com Givaldo Medeiros, em 23.04.2003. Graduouse pela FAU/USP São Paulo, em 1987. conseqüentemente, diminui a atenção ao desenho. Vai para a escala urbana, macro, 1:200 ou menor. Na verdade, na FAU/USP, a questão gráfica sempre esteve presente, mas relacionado ao urbano, à embalagem, à comunicação visual, ao design (MEDEIROS, 2003). ${ }^{7}$

Siegbert Zanettini, em seu trabalho O Ensino de Projeto na área de Edificação, afirma que:

[...] No entanto, a partir de 64 com a mudança do rumo político do país, cujo modelo de desenvolvimento paulatinamente visou atender um conjunto de objetivos de ordem política ideológica, essas críticas entram numa espiral crescente e atingem proporções nunca antes alcançadas. A crise no ensino quase sempre mal encoberta em todo o último decênio, aparece agora com contornos bem visíveis. Apesar disso torna-se difícil à cada escola, a compreensão ordenada das causas globais e externas que prepararão o espaço para o afloramento das causas internas e específicas.

[...]Passa-se para a década seguinte na euforia arquitetônica de Brasília e para um dos períodos de maior produção dentro da escola. As atividades profissionais germinadas no período anterior originaram a visão seqüencial do urbanismo, do objeto e da comunicação visual. A reforma de 62, o fato inicial mais significativo da nova estrutura cria os departamentos e as sequências.

[...] Como decorrência, o arquiteto, cada vez mais compromissado com as relações de produção e com o questionamento do processo cultural, necessita de uma formação que o prepare a atuar "de maneira crítica, frente às exigências do momento presente, bem como participar do processo de transformações desejáveis" e nessa formação, como específico, a globalização de aspectos artísticos, tecnológicos e científicos (ZANETTINI, 1980, p.17-22).

PUNTONI, em sua tese de doutorado $O$ desenho técnico e o ato criador do arquiteto, precisa que os novos recursos de representação do objeto da arquitetura, por meio de figurações gráficas, bem como os conhecimentos teóricos dos meios técnicos, vieram facilitar o afastamento do arquiteto do 
canteiro de obras, determinado por fatores socio-econômicos, inaugurando uma nova maneira de produzir o objeto da arquitetura:

Com esta fragmentação da passagem do projeto à execução da obra, o arquiteto não precisou mais permanecer no canteiro, não acompanhando mais todos os fatos e eventos de sua execução. $O$ arquiteto deixou, portanto, de ser o construtor do objeto da arquitetura e tornou-se seu autor (PUNTONI, 1997, p.48).

E observou que:

A preocupação do arquiteto com a execução da obra se reduziu aos conhecimentos teóricos. Os fatos e eventos relacionados à construção, as medidas tomadas no canteiro de obras, os meios técnicos, os procedimentos operativos, a escolha e uso dos materiais de construção de acordo com os desempenhos, a preparação dos terrenos, a locação, enfim, a execução da obra deixaram de ser considerados para a qualificação do objeto da arquitetura. $O$ objeto da arquitetura concebido em si, representado pelas figurações geométricas, é que realmente passou a ser considerado pelo arquiteto o seu verdadeiro produto, a ponto de não mais se referir ao objeto produzido, mas, aos projetos, que afinal são meros modelos (PUNTONI, 1997, p.53).

O problema, atualmente, parece residir no fato de que está havendo uma falha, um descaso, justamente no ensino das condições necessárias ao arquiteto para se afastar do canteiro: domínio mínimo da representação gráfica e dos conhecimentos técnicos da construção.

Não se trata, pois, de o arquiteto voltar a ser mestre-de-obras tal como no passado, no processo construtivo tradicional, mas de que deve reassumir, fazendo uso das palavras de FIALHO (2002, p.26), o seu papel de construtor que, através do desenho, concebe, desenvolve e controla todo o processo construtivo.

PUNTONI defende que "o arquiteto só voltará a ser construtor e realmente arquiteto, e não simples autor de projetos, quando encontrar um processo construtivo em que não se encontre mais alienado da cultura da produção, que é o processo construtivo industrializado" (PUNTONI, 1997, p.58).

Antes, aponta:

A alienação do arquiteto da cultura de produção, na fragmentação da passagem do projeto à execução da obra, fica muito patente na rotina para obtenção de licença para construir na cidade de São Paulo. Exige-se a apresentação de uma documentação con- 
stituída de um ou mais desenhos e o memorial descritivo, que é a planta legal do edifício, onde o arquiteto assume a autoria e responsabilidade técnica pela sua construção. A planta legal, que pelo próprio nome nada tem que ver com a execução da obra, que deveria ser realizada mediante os projetos arquitetônico $e$ tecnológico, tem sido freqüentemente considerada, pelo próprio arquiteto, suficiente para isso (PUNTONI, 1997, p.53).

É preciso resgatar a importância do desenho técnico arquitetônico, que não deve ser apenas pura representação espacial da arquitetura, mas, também, à ótica da sua construtibilidade, o registro do sistema construtivo (colunas, vigas, lajes etc.) e a "materialidade" dos materiais (alvenaria, concreto, ferro, madeira etc.). Assim, o aluno estará, verdadeiramente, aprendendo a elaborar o raciocínio construtivo do edifício projetado e desfrutará, conseqüentemente, de maior facilidade em representá-lo, uma vez que, em princípio, somente desenhamos o que sabemos representar, se soubermos o que estamos desenhando.

Roberto Novelli Fialho destaca que o desenho pretende, neste momento, não mais ser apenas o que define a forma final pretendida, mas que pretende indicar os modos de pensá-la, obtê-la e executá-la (FIALHO, 2002, p.20).

PUNTONI, em sua pesquisa (1997, p.174-189), descreve o panorama-drama do "não-desenho". Aponta que o arquiteto, na fragmentação da passagem do projeto à obra, alienando-se da cultura da produção, precisa conhecer geometria descritiva e estar treinado a fazer desenhos, para conceber o objeto da arquitetura. Considerando-se intelectual, afastou-se do canteiro e permaneceu isolado no seu ateliê, de modo inconsciente, perdendo a sua condição de mestre-de-obras e tendo de recorrer a modelos gráficos, literários e numéricos. 0 uso da geometria projetiva e do desenho técnico há muito tempo revelaram-se os melhores meios, tanto para a invenção do objeto da arquitetura, como para a elaboração dos projetos arquitetônicos e tecnológi-

${ }^{8}$ Embora este trabalho tenha recorte estabelecido somente na área do desenho, os modelos tridimensionais, como maquetes, são recursos valiosos e indispensáveis para a concepção e produção da arquitetura. $\cos ^{8}$. Os desenhos técnicos tornaram-se, nesse contexto, o único meio para a concepção e execução da obra.

Coloca PUNTONI que o problema reside em que os programas de ensino e os planos de trabalho pressupõem que o aluno já tenha conhecimento de geometria euclidiana, da geometria descritiva e do desenho técnico, e que já esteja treinado a produzir desenhos, o que comprova não ser verdade. Os alunos não se encontram preparados e mesmo assim fazem desenho técnico e devem elaborar projetos arquitetônicos, realizar levantamentos planimétricos, e "ler" e interpretar plantas, cortes e fachadas de edifícios, situando-se 
mais como "vítimas" que como autores de seus trabalhos de projetos. 0 aluno que desconhece desenho técnico está mais treinado e sente-se mais seguro e estimulado a fazer desenhos de observação.

PUNTONI esclarece:

As únicas justificativas que encontramos para que esses programas de ensino e planos de trabalho se estruturem pressupondo esses conhecimentos e treinamento foram, em primeiro lugar, que $o$ ensino da arquitetura pouco mudou em relação aos cursos de arquitetura da Escola Nacional de Belas Artes e da Escola Politécnica da USP São Paulo, da década de quarenta, quando se aprendiam geometria euclidiana e geometria descritiva e se treinava a habilidade de fazer desenhos nos cursos de $1^{\circ}$ e $2^{\circ}$ graus; e, em segundo lugar, que se consideram desnecessários esses conhecimentos e teinamento para o desenvolvimento do curso, pois, de um modo ou de outro, a aluno acaba aprendendo e treinando, como se esses conhecimentos fossem inatos, como a aptidão de fazer desenhos. $O$ curso de arquitetura da FAU/USP, por exemplo, instituído em 1948, foi reformulado em várias oportunidades, embora não se tenham considerado, nessas ocasiões, as mudanças do ensino do $1^{\circ}$ e $2^{\circ}$ graus, com a exclusão do ensino da geometria euclidiana e geometria descritiva e do treinamento da habilidade de fazer desenho, para que o método operativo para a produção do objeto da arquitetura fosse reformulado, adaptando-se a essa nova realidade do ensino médio. A comprovação desses desconhecimentos e dessa falta de treinamento do aluno está nos fracos desempenhos nas disciplinas de composição arquitetônica do curso de arquitetura da FAU/USP, o que levou à instituição das provas de desenho geométrico (PUNTONI, 1997, p.178).

O autor continua:

Se os modelos, em especial as figurações geométricas, passaram a ser os meios pelos quais "visualiza" mentalmente a construção do objeto da arquitetura que está concebendo, passaram também a ser os prepostos no canteiro de obras, a quem delega o seu papel de mestre-de-obras. $O$ estudante de arquitetura, como não tem nem a hipótese de poder verificar a execução de uma obra, tem que aprender a construir teoricamente, e para isso só pode contar com as figurações gráficas, as projeções ortogonais, único meio para poder exercitar o seu ato criador. Portanto, para que estude arquitetura é preciso conhecer geometria euclidiana, geometria descritiva e desenho técnico e se encontre treinado em fazer desenhos. Comprovamos, também, que os desenhos de observação e os desenhos técnicos são práticas e conhecimentos de todos os arquitetos, ainda que não tenham consciência disso. Só fazendo desenhos e fazendo desenhos técnicos o arquiteto e o estudante de arquitetura estão em condições de conceber a construção do objeto da arquitetura. Ignorar este fato ou fazer de conta que não existe é não se importar com o melhor desempenho do aluno nos cursos de arquitetura, com a melhoria quantitativa e qualitativa 
da sua produção de desenhos e com a garantia de sua presença nos ateliês de projeto, para ser mais bem assistido pelos professores (PUNTONI 1997, p.180).

Maurício Porto escreve a respeito dos desenhos de perspectiva:

O que tenho procurado transmitir a meus alunos é que o arquiteto precisa falar desenho, desenhar idéias e criar espaços arquitetônicos e de trabalho, porque atualmente as dificuldades para o profissional recém-formado são imensas, principalmente para aqueles incapazes de se expressar através do desenho. [...] Procuro seguir, a meu modo, o estilo de aula de dois excelentes professores da época - Norbertino Bahiense Filho e Célio Pinto de Almeida -, cujos ensinamentos de geometria descritiva e geometria me são até hoje valiosos. [...] Recomendo sempre que, ao fazer uma perspectiva, façam-na rigorosamente a método. Não é com deformações no desenho que se deve procurar emoção e a surpresa do novo, mas, sim, na criação arquitetônica. [...] A importância da perspectiva está principalmente no desenvolvimento da percepção espacial, além de ser um caminho eficiente para se chegar ao desenho de croquis, ao qual tenho dado especial atenção, devido ao fato de considerá-lo fundamental no processo de criação e um meio de comunicação. [...] Le Corbusier ilustrou sempre todo o seu pensamento teórico (arquitetônico e urbanístico) com centenas de croquis, perspectivas e maquetes, que facilitam a compreensão de sua gigantesca obra, influenciando milhares de arquitetos de todo o mundo. [...] $O$ arquiteto que desenha bem é sempre bem-vindo num escritório de arquitetura. $O$ desenho abre as possibilidades de trabalho e, principalmente, as portas da criatividade. [...] Hoje em dia, é um absurdo a maioria dos arquitetos do Rio de Janeiro formarem-se sem saber desenhar um croqui ou uma perspectiva.

${ }^{9}$ Maurício Porto, autodidata, não chegou a se formar arquiteto, é professor de desenho e perspectiva (pelo menos até a data da publicação deste artigo) do Museu de Arte Moderna do Rio de Janeiro. Nos últimos quatro anos (daquela época), seus cursos no MAM e no IAB-RJ tinham tido a freqüência de mais de dois mil e quinhentos alunos, entre arquitetos, estudantes de arquitetura e professores universitá rios (Revista Módulo, n.87, p.58-61. Rio de Janeiro, 1985). Os estudantes de arquitetura têm o direito a esta formação que considero básica dentro das Faculdades. [...] Há uma ligação direta e profunda entre desenho e arquitetura, entre desenhar bem e ser um arquiteto criativo. Todos os grandes arquitetos desenhavam e desenham bem. Arquitetos que não sabem desenhar ficam prejudicados em todos os sentidos, principalmente na sua percepção e criatividade espacial [...], têm em geral o modo de pensamento verbal, linear, seqüencial e analítico do hemisfério esquerdo. Partem do particular para o geral, têm grande dificuldade para visualizar e imaginar a forma final, o todo. Não têm visão global: normalmente, projetam como se existissem somente duas dimensões [...]. Ao ensinar perspectiva e desenho, o que estou querendo dizer aos meus alunos é que não sejam arquitetos de plantas e fachadas, arquitetos de duas dimensões, que tirem os pés do chão e saiam do plano, que aprendam a voar no espaço infinito da criação. [...] A maquete, a perspectiva e o croqui são poderosos veículos espaciais (PORTO, 1985, p.58-61) ${ }^{9}$.

O método operativo de produção do objeto da arquitetura - cita PUNTONI também se ressentiu de suas conseqüências, principalmente quanto às neces- 
sidades de conhecimentos do uso e desempenho dos materiais de construção, das técnicas construtivas disponíveis e dos sistemas de representação, que passaram a ser, em muitos casos, apenas conhecimentos teóricos. 0 arquiteto, que antes construía e dominava a construção, atualmente apenas sabe representar o que sabe construir.

Isto vai ao encontro de um dos diagnósticos que verificamos em nossa pesquisa, quanto à falha do ensino do desenho arquitetônico, comprovado na análise dos manuais, como será visto mais adiante, que pouco transmitem sobre a materialidade das construções, como se o desenho arquitetônico fosse somente uma mera representação espacial, formal ou volumétrica do objeto arquitetônico.

PUNTONI (1997, p.181) menciona que a maioria das matérias técnicas não são levadas muito a sério nos cursos de arquitetura, como se houvesse uma espécie de preconceito em relação à capacidade de os alunos de arquitetura de aprendê-las. Essa postura, bastante usual, faz com que as matérias técnicas não sejam realmente ensinadas e aprendidas, constituindo-se em simples transmissão de um verdadeiro receituário.

Os cursos de arquitetura pressupõem que o aluno selecionado - nas provas do vestibular e de habilidade específica em desenho - realmente saiba desenhar, que fazer desenho não seja um desafio para ele e, portanto, ele se encontre disposto e apto a usar as figurações gráficas; embora a pesquisa que PUNTONI realizou comprova que isso não é verdadeiro, pois a maioria dos alunos selecionados nunca teve qualquer treinamento da habilidade de fazer desenho ou estudou desenho técnico.

PUNTONI destaca que, em parte, esta situação é também responsabilidade dos alunos:

O aluno selecionado para os cursos de arquitetura, ainda que de modo inconsciente, tem parte da responsabilidade pelo que vem acontencendo com o ensino de arquitetura. Em vez de assumir, quando inicia o curso, que não conhece desenho técnico e que não está treinado a fazer desenhos, obrigando a uma reformulação dos programas de ensino e planos de trabalho, omite-se. É uma atitude injustificada, pois não é nenhum demérito desconhecer um assunto que nunca teve oportunidade de aprender. Talvez possa até ser explicada essa atitude. Acreditamos, pelo que pudemos constatar, que é omisso pela vaidade de querer passar por uma pessoa preparada, ou pela vergonha de ter que revelar sua ignorância, ou por supor que deveria mesmo conhecer essas matérias, ou por 
julgar que realmente "sabe desenhar", pois, afinal, passou nas provas de desenho, enfim, por várias razões que podem explicar, mas não justificar, esse seu comportamento. Assim, praticamente desorientado, o aluno acaba fazendo de conta que conhece e que está treinado a fazer desenhos e passa a resolver as questões que lhe são propostas mediante os mais variados expedientes (PUNTONI, 1997, p.182).

Esta constatação não chega a ser verificada, em sua totalidade, aqui na escola da USP/São Carlos, pois os alunos reconhecem suas deficiências ao longo do curso e os professores de desenho - incluímo-nos -, cientes dessa carência, introduzem, mesmo que rapidamente, pois as horas-aula são poucas, os princípios básicos do desenho técnico, e o desenho arquitetônico é ministrado com razoável importância, tanto como representação como na exposição, apresentada nos desenhos, dos distintos materiais de construção e sistema construtivo adotado. Mesmo assim, assistindo-os ao longo do curso, concluímos que seriam necessárias mais horas-aula para uma efetiva assimilação e prática desses conceitos.

Comprova PUNTONI (1997, p.184) que o aluno, com sua habilidade de fazer desenho, produz mais e melhores desenhos e, por conseguinte, passa a usar mais os desenhos para comunicar suas idéias e pensamentos e perde o medo de produzí-los, pois acaba se convencendo de que o desenho não é apenas um produto artístico. Continua esse pesquisador que, freqüentemente, as pessoas não são treinadas a fazer desenhos, o que faz com que nunca usem desenhos para manifestar-se. 0 estudante de arquitetura não foge a essa regra. Todavia, pela condição como é arregimentado, é sempre uma pessoa um pouco mais treinada a fazê-los. Mesmo assim, não se encontra suficientemente treinado a fazer desenho para que possa ter um desempenho satisfatório no curso de arquitetura, onde fazer desenhos é essencial.

O seu treinamento da habilidade de fazer desenhos [...] é indispensável para que possa, sempre, melhorar sua produtividade e aumentar as possibilidades do exercício do seu ato criador. Porém, o estudante de arquitetura encontra-se pouco treinado a fazer desenhos e tem muita dificuldade no uso das figurações gráficas. Como perdeu o hábito de fazer desenhos, evita tudo o que o obriga a fazê-los. Só faz desenhos quando é forçado a isso e não sente nenhum prazer em fazê-los. A produção de desenhos, nessas condições, é reduzida e sem muita qualidade. Quando é obrigado a fazer desenhos, raramente produz mais que o mínimo necessário, e mesmo assim os desenhos são tão pequenos e tão claros que quase desaparecem na folha de papel. Essas observações não constituem críticas ao estudante de arquitetura, mas uma constatação das suas dificuldades e, por conseqüência, da necessidade do treinamento da habilidade de fazer desenhos. $O$ aluno 
se mostra inibido, tem medo de errar, procura não expor para não ouvir comentários desagradáveis sobre os seus desenhos, enfim, age como todas as pessoas que, desde a infância, foram condicionadas a pensar que só artistas produzem desenhos e, como não são artistas, que não devem produzir desenhos, deixando assim de produzir. $O$ treinamento da habilidade de fazer desenhos, entre outras coisas, acaba eliminando esse modo de ver a produção dos desenhos. A partir da eliminação de mau hábito, o aluno começa a fazer desenhos com fluência e desenvoltura, preocupado simplesmente em usá-los como instrumento de linguagem e não como instrumento expressivo (PUNTONI, 1997, p.186).

Sabemos o sentido que PUNTONI dá ao desenho como instrumento expressivo, que é da ordem do desenho artístico. Porém, acreditamos que há uma expressividade que deve ser procurada também nos desenhos técnicos: espessuras distintas de traço, hachuras, texturas, claros-escuros etc., as mesmas qualidades da expressividade do desenho artístico, mas adaptadas ao desenho técnico, com cuidado, bom senso, em que a prioridade está na clareza das informações a serem transmitidas.

Podemos verificar outras falhas nos desenhos arquitetônicos de alunos que pouco treinaram (ou pouco foram instruídos): linhas que não se encontram, o que detecta que não entendem que esse conjunto de linhas representa um material de construção, devendo "fechá-los" sempre em retângulos; carência de complementar os desenhos com textos, não imaginando que o professor terá de adivinhar que uma linha tracejada, por exemplo, indica a projeção de alguma coisa do andar superior etc. Além disso, não há correspondência completa entre planta, cortes e vistas, o que denuncia que ainda não assimilou perfeitamente o entendimento da geometria projetiva, além de não compreender, totalmente, a representação dos materiais e o funcionamento da estrutura do edifício desenhado.

Mais adiante, PUNTONI destaca outras desantenções, devido à falta de habilidade de expressar-se pelos desenhos:

[...] as figurações geométricas revelam pouca preocupação com precisão, clareza e disposição das informações, desinteresse por qualquer aperfeiçoamento da sua 'gramática', muita deficiência na apreensão da proporcionalidade dos atributos visuais dos objetos observados ou 'visualizados' mentalmente, muita exclusão de detalhes significativos, necessários a uma boa compreensão e muita inclusão indevida de ilustrações desnecessárias, o que evidencia uma contradição entre a expectativa dos programas de ensino e os reais conhecimentos e treinamentos do aluno (PUNTONI, 1997, p.187). 
Identificadas as principais causas da falta de rendimento do estudante de arquitetura, nas questões referentes ao seu desenho, para PUNTONI (1997, p.187-188) ficam evidenciadas algumas providências que, a serem tomadas a curto e a médio prazos, podem contribuir significativamente para a mudança dessa situação: o estudo da geometria euclidiana, geometria descritiva e desenho técnico; a realização sistemática e contínua de treinamentos da habilidade de fazer desenhos e gestões junto às autoridades competentes para a inclusão destes estudos nos currículos dos cursos fundamentais, médios e superiores.

Os desenhos têm, portanto, duas finalidades para o arquiteto na representação do objeto da arquitetura: uma na sua concepção e outra na sua produção (PUNTONI, 1997, p.34). Estas considerações coincidem com os estudos que Yves Deforge empreendeu em Le graphisme technique: son histoire et son enseignement, em que discorreu sobre a evolução do desenho técnico:

A evolução do ensino do desenho se findou com uma profunda mutação. Enquanto que anteriormente o ensino estava centrado na racionalidade da representação, foi sobre a racionalidade da construção que ele se centrou a partir daí. Racionalidade em dois níveis, aquele das funções (lógica funcional) e aquele dos objetos (lógica técnica ou tecnológica) (DEFORGE, 1981, p. 234).

Mais adiante, menciona:

O professor de desenho devia se considerar "essencialmente encarregado do curso da construção" [...] Os programas de liceus técnicos confirmavam ou inspiravam essa orientação, apresentando brevemente as convenções técnicas do desenho, "que devem ser ensinadas à altura dos estudos tecnológicos"; um desenho industrial 'sendo, sobretudo a tradução gráfica da organização funcional e arquitetônica de um conjunto ou de uma peça desse conjunto' (programa de 1967), apesar de ser dito no programa que o desenho não devia se reduzir a um gráfico, a um esquema ou a um traçado de superfícies funcionais, o "objetivo ideal" era ensinar aos alunos "a conduzir uma análise técnica, a reconhecer as funções técnicas e a saber agenciá-las logicamente" (DEFORGE, 1981, p. 236-237).

PUNTONI esclarece a situação do arquiteto de hoje:

A alienação do arquiteto da cultura de produção limitou sua capacidade produtiva e privou-o da experiência necessária para o acesso ao entendimento da natureza, expresso pela ciência. A teoria das técnicas construtivas e do uso dos materiais de construção parece-lhe inacessível, pelo pouco contato com a experiência, com os fatos e eventos da execução da obra. Além 
do mais, a modernidade, época da profunda divisão entre o sujeito e objeto, apresenta-lhe a teoria das técnicas não como uma criação do ser humano, e sim como algo que the transcende, $o$ que lhe provoca mais dúvidas e incompreensão e contribui para agravar esse seu comportamento negativo com relação à teoria das técnicas construtivas. $O$ desperdício da sua capacidade, que é uma das características da existência moderna, choca-se contra a contraditória realidade, que reconhece a sua possibilidade de realização, autenticidade e possibilidade de acesso à experiência humana. $O$ arquiteto experimenta um mundo cheio de possibilidades, enquanto fica fechado em uma prisão feita de estruturas estéticas, éticas e cognitivas conflitantes. Com o modernismo, sente-se ao mesmo tempo estimulado e frustrado [...] 0 arquiteto precisa, frente à sua provável extinção, recolocar para a reflexão a questão da sua alienação da cultura de produção (PUNTONI, 1997, p.54).

A aquisição e conseqüente aplicação de conhecimentos técnicos de construção durante a etapa de projetação não se constitui num empecilho à criação. Antes, mune o autor de elementos mais precisos, paupáveis, reais e viáveis. Este, que procura e retém tais conhecimentos, vai mais longe e encara as possibilidades de projeto e sua construtibilidade como desafios naturais e saudáveis. 0 arquiteto Rino Levi, cujos desenhos de projeto executivo são exemplares e refletem a qualidade das soluções de projeto - resultado de sua determinação em resolver previamente os detalhes construtivos, revelando seu nível de conhecimento da técnica construtiva empregada na execução de seus projetos -, escreveu:

É errado supor que a bagagem de conhecimentos indispensáveis ao arquiteto possa limitar sua capacidade criadora. É errado supor também que o objetivo prático da obra de arquitetura possa entravar a liberdade de concepção. O artista saberá encontrar sempre sua própria e vigorosa expressão superando quaisquer injunções (LEVI, 1958 apud FIALHO, 2002, p.39).

Pode acontecer ainda, e não devemos temer, que o processo de criação implique re-inventar ou ampliar as possibilidades da técnica. Alguns projetos do arquiteto Niemeyer, por exemplo, reivindicaram novas demandas de cálculo estrutural, cujos resultados elevaram os conhecimentos e aplicações técnicas desses engenheiros a patamares mais ousados.

Vale relembrar alguns itens do artigo $3^{\circ}$ da Proposta de Diretrizes Curriculares Nacionais para o Ensino de Graduação em Arquitetura e Urbanismo (MEC/ Secretaria de Educação Superior, 1998), que reza: "A educação do arquiteto e urbanista deve garantir uma relação estreita e concomitante entre teoria 
e prática e dotar o profissional dos conhecimentos e habilidades requeridos para o exercício profissional competente", a saber (citamos somente os relacionados ao assunto deste trabalho):

c) as habilidades necessárias para conceber projetos de arquitetura, urbanismo e paisagismo e para realizar construções, considerando os fatores de custo, de durabilidade, de manutenção e de especificações, bem como os regulamentos legais, e de modo a satisfazer as exigências culturais, econômicas, estéticas, técnicas, ambientais e de acessibilidade dos usuários;

g) os conhecimentos especializados para o emprego adequado e econômico dos materiais de construção e das técnicas e sistemas construtivos, para a definição de instalações e equipamentos prediais, para a organização de obras e canteiros e para a implantação de infra-estrutura urbana;

h) a compreensão dos sistemas estruturais e o domínio da concepção e do projeto estrutural, tendo por fundamento os estudos de resistência dos materiais, estabilidade das construções e fundações; e

k) as habilidades de desenho e o domínio da geometria, de suas aplicações e de outros meios de expressão e representação, tais como perspectiva, modelagem, maquetes, modelos e imagens virtuais.

Parece haver, portanto, um elo perdido na configuração do novo arquiteto, que se afasta do edifício, do canteiro. É precisamente, como destaca PUNTONI, o resgate necessário da apreensão da tecnologia e seu conseqüente comparecimento nos desenhos de arquitetura:

Porém, o arquiteto que foi mestre-de-obras do passado, ainda que produza o objeto da arquitetura por meio de desenhos, só virá a ser o construtor do futuro quando se integrar ao modo de produção industrial. Não há dúvida que deseje essas transformações que parecem concordar com a finalidade precípua que persegue (PUNTONI, 1997, final do resumo).

Cabe a nós professores, revermos, dentro das possibilidades e condições do currículo atual do curso de arquitetura, nossas aulas, nossas metodologias, com o fim de aliar, efetivamente, as representações de desenho com o conhecimento da produção da arquitetura. A longo prazo, resgatar o espaço perdido, dentro do ensino da arquitetura, da importância vital do desenho, do desenho técnico e tecnologia construtiva, frente a outros conhecimentos 
necessários para a formação do arquiteto, concretizado em criar uma nova postura entre os professores de desenho, tecnologia e projeto, na busca efetiva de novos meios de ensino e na reivindicação de mais horas-aula para viabilizar estas intenções. 


\section{Análise do questionário}

Como foi apresentado na introdução deste trabalho, pretende-se analisar o atual estado de ensino de desenho arquitetônico nas escolas/faculdades de arquitetura do país.

O questionário, um dos itens de procedimento desta pesquisa, foi a forma escolhida para a obtenção de um mapeamento de como o desenho técnico arquitetônico está sendo ministrado pelos professores, investigando sua atualidade, os recursos técnicos e didáticos utilizados em suas aulas, que metodologias são adotadas, como vêem os sistemas CAD, que iniciativas estão surgindo, que pesquisas estão sendo realizadas na área etc. Sobretudo, este questionário é mais um expediente para angariar subsídios para a reflexão sobre o desenho técnico arquitetônico, tendo em vista uma efetiva contribuição ao ensino do mesmo.

Este questionário, que se encontra na íntegra na seção de Anexos, está restrito somente às questões do desenho técnico arquitetônico e subdivide-se, para maior clareza, em blocos: A) identificação da escola; caracterização do curso/ escola e do professor; B) disciplina principal e disciplinas complementares; C) recursos; D) metodologia; E) os desenhos e o canteiro de obras; F) questões sobre o CAD; e H) finalização, com um espaço para colocações livres dos professores. 
Sobre a ferramenta CAD, que rapidamente tomou corpo, ganhou espaço, conquistou quase todos e pretende ser um processo irreversível, um novo divisor, parece ser este o momento oportuno de analisá-la, frente às novas tecnologias do computador e de refletir sobre o desenho arquitetônico, fazendo-se necessário chegar a um consenso. Para isso, é preciso nos munirmos de critérios, informações, bases, orientações corretas etc.

Muitas questões de desenho de arquitetura em geral, de conceituações ou de utilização do desenho como ferramenta de criação/concepção, não foram aventadas, pois a pesquisa se atém ao recorte do desenho técnico arquitetônico, à linguagem técnica de representação de projetos de arquitetura. Tanto assim é que um dos professores enviou a seguinte observação, pelo correio eletrônico, após ter respondido ao questionário:

Acredito ser importante o aprendizado da leitura do projeto através de planta, corte e vistas e que esta forma de leitura do projeto possa ser feita nos primeiros semestres. Mas, durante o curso, outras formas de representação devem ser discutidas, pois as tradicionais plantas, cortes e elevações são insuficientes para fazer pensar sobre as qualidades ambientais do espaço ( $\mathrm{P}$. T., 2003). ${ }^{1}$

Deve-se notar que, no decorrer das questões, há um mote que se atém às cotas (dimensionamento) com certa profundidade, justamente por ser consideradas importantes: deve haver toda a precisão possível, devendo ser isentas de erros já no primeiro trabalho profissional de um recém-formado.
${ }^{1}$ Citações dos professores respondentes a este questionário serão identificadas pelas iniciais de seus nomes.
Dentre as 150 escolas/faculdades de arquitetura do país, conseguimos contactar aproximadamente 60. De cada uma delas obtivemos nomes e endereços eletrônicos de dois ou três professores, resultando um total aproximado de 140 nomes, dos quais 59 responderam ao questionário. 
Toda enquete ou questionário apresenta dificuldades, não só na sua elaboração e posterior tabulação, como também na busca dos respondentes, do público desejado. Este não foi exceção: na elaboração do questionário, o que mais sentimos foi a absoluta falta de experiência, aliada ao pouco tempo disponível, uma vez que a decisão por este procedimento não aconteceu já no início da pesquisa. Daí que, em busca de respostas que efetivamente servissem às análises, o número de questões foi crescendo, principalmente quando optamos por contemplar algumas relativas ao CAD.

Iniciamos a pesquisa das escolas/faculdades de arquitetura pela página eletrônica da ABEA - Associação Brasileira de Ensino de Arquitetura (www. abea-arq.org.br), de onde conseguimos a listagem das escolas brasileiras. A partir dessa lista, ainda por meio eletrônico, pudemos nos valer dos buscadores a fim de chegar à pagina de cada escola. A idéia consistia em conseguirmos os endereços eletrônicos dos professores de desenho. Algumas das páginas eletrônicas não abriam ou estavam em manutenção; quando permitiam o acesso, obtínhamos seu endereço, telefones e endereços eletrônicos para contato. Muitos destes dados, como já prevíamos, estavam desatualizados. Algumas vezes, quando conseguíamos efetivar um telefonema, a pessoa que atendia não tinha autorização para divulgar os endereços eletrônicos dos professores que desejávamos contatar. Ainda assim, conseguimos muitos deles ao entrar em contato direto, por telefone ou correio eletrônico, com os coordenadores de curso.

Não podemos ainda desconsiderar o fato de que, nos momentos mais intensos de nossa pesquisa de dados, os professores das universidades federais encontravam-se em férias, em razão das alterações de calendário decorrentes da greve de 2002, deixando assim de responder ao questionário.

Uma vez de posse dos endereços eletrônicos de aproximadamente 140 professores, enviamos estrategicamente duas mensagens explicando a pesquisa pretendida e anunciando que sua participação consistia em responder a um questionário, por via eletrônica. Muitos mostraram-se prestativos ao responderem, colocando-se prontamente à disposição, no aguardo do envio deste questionário. Alguns parabenizaram a iniciativa; outros queriam, de certa forma, participar deste "grupo" de pesquisa em desenho arquitetônico. 
Dos 59 professores que responderam, de 36 escolas diferentes, que responderam ao questionário, identificamos suas procedências, ilustradas na tabela a seguir:

Bloco B

\begin{tabular}{l|c|c|c|c}
\hline & Pública Federal & Pública Estadual & Pública Municipal & Particular \\
\hline Alagoas & & & & 1 \\
\hline Bahia & 4 & & & \\
\hline Distrito Federal & 2 & & & \\
\hline Espírito Santo & 1 & & & 2 \\
\hline Minas Gerais & 1 & 2 & & 2 \\
\hline Mato Grosso & 3 & & & 6 \\
\hline Paraná & & & & 1 \\
\hline Rio de Janeiro & 7 & & & 4 \\
\hline Rio Grande do Sul & & & & 12 \\
\hline Santa Catarina & 18 & 11 & 1 & 1 \\
\hline São Paulo & & & & 29 \\
\hline Santo Domingo & & & & \\
\hline Total (59) & & & & \\
\hline
\end{tabular}

Perfil das escolas e dos professores

As estastísticas de abertura de novas escolas de arquitetura, citadas no capítulo anterior, são confirmadas ao checarmos as idades dos cursos. Da coleta de respostas, podemos verificar que há cursos de arquitetura que completam seu jubileu de ouro, como os de algumas escolas públicas, como a Faculdade de Arquitetura da UFRGS e a Escola de Design da UEMG e a da UFPR, que completa 40 anos, enquanto alguns completam seus primeiros anos de existência, como os de Cascavel, Chapecó, Maceió e UnicenP de Curitiba.

Dos 59 professores que responderam ao questionário, 53 são arquitetos. Dentre os professores que não são arquitetos podemos observar que: dos dois professores da Universidade de Brasília, um deles é engenheiro civil e ministra Representação Gráfica para Engenharia Civil 2 na Engenharia Civil e Ambiental; da Fau da Univali - Universidade do Vale do Itajaí -, em CamboriúSC, o professor possui Licenciatura em Desenho; mais um outro tem esta formação e atua no CAU da Universidade do Vale da Paraíba, em São José dos Campos-SP, ministrando aulas de Geometria Descritiva; da Faculdade de Arquitetura, Artes e Comunicação da Unesp de Bauru-SP, o professor tem formação em Desenho Industrial e ministra Desenho Técnico Civil; um professor 
da Escola de Arquitectura y Artes da Universidade Iberoamericana, de Santo Domingo, também respondeu ao questionário, embora este empreendimento atenha-se somente às escolas brasileiras (o professor deve ter acessado a página eletrônica do Programa de Pós-Graduação em Arquitetura e Urbanismo da Escola de Engenharia de São Carlos / USP para alguma consulta de seu interesse e acabou chegando ao questionário); por fim, um aluno do último ano da Faculdade de Arquitetura e Urbanismo da Unimep, de Santa Bárbara do Oeste-SP, também respondeu. Por outro lado, há docentes arquitetos em disciplinas nos cursos da Engenharia Civil. É o caso do professor de Desenho Técnico na Faculdade de Engenharia Civil da Unicamp, em Campinas, SP.

A faixa de idade dos professores respondentes atinge a média de 39.3 anos, variando entre 26 e 66 anos. Entre eles, alguns lecionam a matéria de desenho arquitetônico há 25 anos, enquanto que outros estão começando. Quanto a seus níveis de formação, há oito professores-doutores, sete doutorandos, 11 mestres, 15 mestrandos, nove especializados, um especializando e oito professores que pretendem ingressar em algum programa de Pós-graduação.

A variação de perfis - idade do curso, dos professores, sua formação -, é rica e contribui com dados para uma estimativa do atual estado de ensino de desenho arquitetônico; mesmo que não sejam arquitetos ou não dêem aula da matéria, ainda assim acrescentam contribuição ao trabalho. Suas respostas, principalmente nas questões opiniáticas, são valiosas e nos remetem à reflexão quanto às grandes idéias que direcionam o ensino e a prática do desenho arquitetônico.

Bloco $C$ Disciplina principal e complementares

A percepção do empobrecimento ou desleixo no ensino de desenho técnico arquitetônico, das plantas, cortes e vistas etc., que constituem os desenhos básicos, linguagem mínima de todo arquiteto, moveu-nos a empreender este trabalho de verificar, de constatar o atual estado de ensino desta matéria, que consideramos importante. Quase todos ( $95 \%$ dos respondentes) concordam que está realmente havendo um empobrecimento (questão 14, do bloco C); 
um deles observa:

É essencial, pois é como se se quisesse formar escritores sem ensinar a escrever corretamente (G.H.T., 2002).

Antes de iniciarmos a análise das respostas, são necessárias algumas explicações. Lendo este trabalho, constatamos que o questionário tem um certo direcionamento, notadamente visível, de questões pontuais, até bem detalhadas, no âmbito do desenho arquitetônico, a tal ponto de um professor respondente fazer uma observação pertinente:

Achei o questionário muito explicativo, algumas questões são opinião do elaborador e não afere, a meu ver, o que realmente penso sobre o assunto. Inserir opinião sobre o assunto numa pesquisa certamente leva para uma resposta dirigida (C.A.S., 2003).

Reconhecemos que houve exagero na condução dessas questões. Aproveitamos para descrever aqui outros percalços ocorridos, que prejudicaram a extração de resultados desejados ou que nem vieram a acontecer. Esses equívocos servem para enriquecer nossa própria experiência de pesquisador que somos, a fim de aferir, em outros empreendimentos, uma metodologia mais afinada, adequada, e até imparcial, isenta de paixões.

Talvez o maior erro - operacional - tenha sido de o questionário conter aproximadamente 80 perguntas, o que desestimula qualquer participante. Outro, em menor escala e sobre o mesmo aspecto, é o de ter sido veiculado totalmente por via eletrônica. No entanto, isso facilitou os envios e retornos. Essas ações, próprias do campo da internet, eram imediatas. Em nenhum momento dependemos dos serviços de correios ou de qualquer outro meio.

Outro problema, que prejudicou uma parte importante do trabalho, foi o de ter sido aberto à participação de professores que lecionam outras disciplinas que não desenho arquitetônico (Projeto e CAD, por exemplo), sem que o questionário estivesse claramente organizado e preparado para isso. Assim, uma professora nos escreveu:

Minhas respostas aos blocos não referentes ao CAD são especulativas, pois não leciono Desenho Arquitetônico ou GD; apenas CAD. Achei seu questionário falho neste sentido, pois não há como você saber qual a matéria lecionada pelo professor (G.C., 2002). 
pelo confuso enunciado, cujas variáveis não soubemos agenciar adequadamente: relação horas-aula, número de alunos x número de professores e monitores, disciplinas regulares e optativas etc. Infelizmente, este mote fica prejudicado, ainda mais com respostas de professores que eram de outras diciplinas respondendo, ora pela sua disciplina, ora pela disciplina em questão. Apenas parte dessas respostas pôde ser analisada.

Ressalta-se como problema, sobretudo, a intenção "tendenciosa", acima citada e reconhecida, sobre o objeto-desenho arquitetônico, permeada em muitas das questões. Neste momento, ao analisarmos as respostas, reelaboraríamos o questionário de forma diferente, se fosse possível uma segunda vez, evitando os percalços cometidos.

Por outro lado, vemos pontos positivos. Acreditamos que a leitura dessas questões pelos professores, mesmo por aqueles que não responderam ao questionário, leva-os a refletirem um pouco, a se auto-questionarem (reafirmando ou não) suas posturas e métodos, a verem que há pessoas preocupadas com o aperfeiçoamento no ensino dessa matéria, a enxergarem outros pontos de vista, novas bibliografias, novos métodos de ensino, como ver os sistemas CAD e suas possibilidades etc.

Outro aspecto importante foi o contato com os professores da área, trocar idéias, ouvi-los - isto aconteceu em alguns casos e deve aumentar com a divulgação dos resultados desta pesquisa. Almejamos com este questionário chegar a todos os professores de escolas/faculdades brasileiras, embora, pelos percalços já destacados anteriormente, poucos professores participaram.

Desejamos esta "provocação", esta tentativa de reunião, em que se pressupõe que todos estejam imbuídos da "nobre causa" do verdadeiro (correto) ensino, esta troca de opiniões e reflexões, cause um movimento, um grupo de estudos e resulte numa massa crítica madura, que possa alimentar as decisões do ensino/mercado. Quem sabe? ...

Como dissemos, esta pesquisa se atém ao desenho técnico arquitetônico, cujo ensino e prática têm sido alvo, cada vez mais, de queixas e reclamações, por parte dos professores de Projeto em relação a seus alunos e por parte de arquitetos (mais antigos) quando da contratação de estagiários ou recémformados. Sendo assim, preferimos analisar e comentar as respostas, não seguindo a ordem do questionário, e sim iniciando, estrategicamente, com a questão 14 , do bloco C, já citada anteriormente: 
cortes, vistas etc.): a) é importante; b) parcialmente importante; c) não é mais tão importante; o aluno acaba aprendendo nos primeiros meses de atuação profissional. Há outras coisas mais importantes - teoria e história da arquitetura e urbanismo, tecnologias construtivas, linguagens visuais, plástica, composição, etc. - para serem transmitidas ao aluno. É preciso formar arquitetos, não desenhistas?; d) outro

Com relação a essa questão, dos 59 respondentes, 55 assinalaram que é importante; um respondente não se manifestou; um assinalou o item "c"; e um deles anotou um comentário (já citado - C.A.S., 2003).

Então, unimo-nos às vozes da maioria, certos de que temos um ponto em comum na construção desta reflexão; querendo detectar falhas, ouvir outros, almejar soluções, lembrando que, em outros aspectos do desenho de arquitetura, haja opiniões diversas e valiosas, uma vez que o campo do desenho é tão amplo e dinâmico como o é a própria arquitetura.

As questões anteriores do mesmo Bloco $\mathrm{C}$, que se referem à disciplina regular de desenho arquitetônico ou disciplinas optativas, infelizmente ficaram prejudicadas, como já anunciamos anteriormente. No entanto, duas delas, isentas deste revés, fornecem-nos alguns subsídios para comentar:

9C: As disciplinas que ensinam Projeto acabam complementando o assunto de desenho técnico arquitetônico?

Dos 56 que responderam, 19 assinalaram "Sim"; 30, "Sim, parcialmente"; e oito "Não".

10C: Os professores de Projeto cobram de seus alunos a linguagem básica da representação do desenho técnico arquitetônico?

A essa questão, 57 responderam; destes, 35 assinalaram "Sim, satisfatoriamente"; e 22, "Sim, parcialmente".

Embora pareçam respostas vagas ou quase equilibradas na balança, entre um sim absoluto e um sim parcial, e respeitando o modo de cada professor de Projeto ensinar esta matéria, estes números registram, a nosso ver, um quadro mais negativo que positivo. Tendo em vista a diminuição de horasaula de desenho arquitetônico, a atitude, por parte dos professores de Projeto, de transmitir aos alunos, sem demandar muito tempo, algumas dicas rápidas de representação seriam muito bem-vindas. É, também, exatamente nestes exemplos práticos de projeto que os alunos colocariam em prática os conceitos do desenho arquitetônico. E cobrar dos alunos - valendo até parte da nota, como muitos já o praticam - a representação gráfica, exigiria destes mais disciplina e interesse em sanar suas carências. Além disso, haveria uma integração maior - presume-se que seja desejável - entre estas duas matérias, 
fomentando a organização de exposições de desenhos e projetos, elaboração de textos, pequenos manuais de representação gráfica, workshops etc. E por que não uma integração também com os professores de Tecnologia?

Há, infelizmente, escolas onde os professores de Projeto é que assumem a tarefa de ensinar a matéria de desenho arquitetônico (não há uma disciplina específica para esta matéria), dividindo seus esforços e tempo isso. Mesmo já registrado no segundo capítulo, achamos oportuno apresentar, novamente, a mensagem (eletrônica) de uma professora, quando da aplicação do questionário:

[...], mas eu sou responsável pela disciplina de Projeto Arquitetônico. Se você achar que eu posso ajudar... me avise que responderei (ao questionário). Irei encaminhar para os professores responsáveis pela disciplina de infomática. Se você me permite um comentário, gostaria de dizer que: hoje, com a redução dos currículos, até o mínimo de 3.600 horas/aula permitido pelo MEC, quase não há, nas escolas particulares de nossa região, a manutenção destas disciplinas - somente há a instrumentalização por meio dos programas clássicos de desenho por computador. Os professores de projeto é que têm a responsabilidade de cobrar e, na medida da possibilidade, orientar sobre a representação das propostas - não se esqueça de que estamos falando de quatro horas/aula por semana em média para as disciplinas de projeto. E os alunos quase sempre fazem cursos de desenho fora da faculdade... mas isto tudo você já deve saber [...] (V.B., 2002).

Por outro lado, embora não tenhamos contemplado esta pergunta, acreditamos também que, em muitas escolas e por motivos diversos, há evidências de professores de outras áreas - projeto, história, tecnologia - "cobrindo" a disciplina de desenho arquitetônico. Não vemos problema nisto, pois todos os profissionais da construção civil - engenheiros e arquitetos, principalmente - somos habilitados, dada à nossa formação, a ensinar desenho arquitetônico, embora alguns o façam com mais facilidade e outros, com menos. No entanto, seria interessante que houvesse mais professores propriamente da área de desenho, que teriam mais tempo para estudar, atualizar-se e preparar material e aulas melhores. Este panorama, juntamente com a colocação desta professora, leva-nos a uma indagação: Será que o resgate do reconhecimento do ensino de desenho técnico arquitetônico não se fortaleceria com o aumento de pesquisa na área? 
A primeira questão do bloco $D$ se refere aos manuais/livros de desenho arquitetônico que os professores adotam (55 professores responderam), cujos itens são:

a) Desenho Arquitetônico [OBERG, Lamartine. Rio de Janeiro, Ao Livro Técnico, reeditado até hoje];

b) Desenho Arquitetônico [MONTENEGRO, Gildo A. São Paulo, Edgard Blucher, reeditado até hoje];

c) Manual de dibujo arquitectónico [CHING, Francis D.K., México, Gustavo Gili, 1978]

d) Representação Gráfica para Desenho e Projeto [CHING, Francis D. K.; JUROSZEK, Steven. Barcelona, Gustavo Gili, 2001];

e) Técnicas de Construção Ilustradas [CHING, Francis D. K.; ADAMS, Cassandra. Porto alegre, Bookman, 2001;

f) Dicionário visual de arquitetura [CHING, Francis D. K.. São Paulo, Martins Fontes, 1999]

g) Outros:

h) Temos manual próprio:

i) Nenhum

Para maior entendimento, é preciso esclarecer que os manuais do OBERG (reeditado desde pelo menos 1950) e do MONTENEGRO (primeira edição em 1978) são nacionais e de fácil aquisição (atualmente o do OBERG vem se escasseando e as livrarias têm de encomendar); são considerados os mais difundidos e conhecidos. Propomos, portanto, seu agrupamento, e os manuais do CHING formariam um outro agrupamento. Estes últimos, do CHING, não são nacionais na origem (alguns deles foram traduzidos para o português por editoras brasileiras) e têm tido aceitação cada vez maior.

Nesta questão, verificamos que 35 professores adotam o OBERG e 48, o MONTENEGRO. Mas, 32 adotam os dois e 12 professores adotam somente estes (OBERG ou MONTENEGRO, ou os dois) e nenhum manual do agrupamento do CHING.

Ainda, 27 professores adotam livros tanto do primeiro agrupamento (OBERG e MONTENEGRO) como do segundo (CHING).

Os professores que adotam todos esses seis livros somam nove. Somente o professor de Santo Domingo (Escuela de Arquitectura y Artes da Universidade Iberoamericana) adota, evidentemente, somente os do CHING.

Dos usuários do CHING, 30 consultam o Manual de dibujo arquitectónico e 31, Representação Gráfica para Desenho e Projeto. Somente 15 adotam Técnicas de construção ilustradas, por se tratar de um livro de técnicas construtivas e 
menos de desenho arquitetônico; 26 professores adotam o Dicionário Visual de Arquitetura, traduzido e editado, no Brasil, pela editora Martins Fontes.

Dois professores de uma mesma escola (UFBA) indicaram, também, um outro livro: Curso de desenho arquitetônico, de Margarita Chiguir, São Paulo, Gráfica Editorial Ltda., Vol.I a V. Entramos em contato com esses professores para obtermos maiores informações sobre a obra, mas não conseguimos contato com a editora.

Cinco professores complementam suas consultas com apostilas diversas e/ou manuais próprios. Um outro professor consulta também o NEUFFERT (Arte de projetar em Arquitetura). Dois professores de escolas diferentes citaram também a Norma da ABNT, sendo que um deles comentou: "Seguimos aqui

2 Norma ABNT NBR 6492: Representação de projetos de arquitetura, de abril 1994. [...] a Norma 6492 da ABNT. Porém, esta norma deixa a desejar no sentido de não exemplificar, com desenhos, a teoria abordada" (A.M., 2002). ${ }^{2}$

Um professor utiliza o Dicionário Ilustrado de Arquitetura, de Maria Paula ALBERNAZ e Cecília MODESTO; um outro consulta o Comunicação Gráfica Moderna, livro de GIESECKE (2002); e uma professora adota o livro Why architects draw, de Edward ROBBINS (1997) além de ter um manual próprio (eletrônico) em sua página eletrônica.

Verificamos que, por serem mais conhecidos, os manuais do OBERG e MONTENEGRO são adotados, ainda com certa predominância. Os livros do CHING têm alcançado, pelos números verificados, aceitação cada vez maior nos últimos anos, devido ao seu barateamento, já que alguns deles - como havíamos citado - foram traduzidos para o português e aqui editados. Mas, constituem, a nosso ver, livros mais didáticos em muitos aspectos pontuais, mesmo que alguns deles não sejam especificamente livros de desenho arquitetônico. Estes comentários serão melhor expostos no capítulo seguinte, sobre a análise dos manuais.

Da questão dois deste bloco, quanto à biblioteca de suas escolas: 45 professores assinalaram que suas bibliotecas possuem razoavelmente livros e/ou manuais sobre a matéria, enquanto que 11 assinalaram que suas bibliotecas possuem poucos ou quase nenhum desses livros ou manuais.

Da questão três, se utilizam ou não recursos áudiovisuais nas aulas: 50 utilizam, enquanto que seis não utilizam. 
Na questão quatro, 40 assinalam que há pranchetas adequadas, em quantidade suficiente, para a prática do desenho arquitetônico; nove, em quantidades insuficientes; e oito responderam que não há pranchetas adequadas.

A questão cinco investiga se há salas livres (com pranchetas) para que os alunos possam praticar o desenho técnico arquitetônico extra-classe: 14 responderam "sim", e são salas especialmente para este objetivo; 32 também responderam "sim" e são usadas as próprias salas de aula, que os alunos utilizam em horários sem aula; oito assinalaram que não há salas livres e as salas de aula estão sempre ocupadas por outras disciplinas.

As salas-laboratório ou as próprias salas de aula (todas com pranchetas) utilizadas fora do horário de aula, além de se apresentarem com uma infraestrutura mínima para a prática do desenho arquitetônico, propiciam ambiente de trabalho coletivo, onde os alunos acabam se auto-ajudando, o que possibilita a troca de experiências nesta e em outras matérias.

A pergunta seis deste bloco, mais que um elemento de recurso, faz parte, também, dos aspectos de procedimentos de ensino: interessa-nos verificar como pensam os professores sobre o desenho à mão, com instrumentos, e desenhos direto, ou não, no computador. A pergunta é:

\footnotetext{
O desenho técnico arquitetônico é ministrado prioritariamente: a) como prática do desenho somente à mão livre; b) Com instrumentos (régua $T$ ou paralela e esquadros) após certo domínio da prática a mão livre; c) No computador, diretamente; d) Outro modo.
}

Apenas um professor escolheu a primeira opção, da prática somente à mão livre; 43 assinalaram o ensino de desenho com instrumentos após certo domínio da prática à mão livre; e três escolheram a opção de desenhos diretamente no computador (são cursos de Engenharia: UnB, UEMG e Poli USP). Mas, três professores alegaram um ensino integrado, em que as três opções caminham paralelas.

Analisando hoje, esta é, talvez, uma das questões desnecessárias, que parecem buscar respostas óbvias, não fosse a terceira opção (no computador, diretamente), e, neste caso, está mal formulada. Não queremos discutir os procedimentos de ensino diretamente no computador na Engenharia, pois fugiria do enfoque desta pesquisa. É claro e natural que o uso de instrumentos (régua T ou paralela e esquadros) vem depois de certo domínio e prática à mão livre. Conclui-se, ainda que a questão seja confusa, que há um consenso no 
ensino de desenho nas escolas de arquitetura, onde a utilização do computador como instrumento de geração de desenho técnico arquitetônico é posterior, ou pelo menos concomitante, ao desenho na prancheta. Assim, observou-nos um professor respondente:

Deixo registrado que todo tipo de desenho deve, antes, ser aprendido adequadamente, anterior à utilização da computação gráfica. Pois, o que se nota é uma dificuldade crescente em relação à representação dos alunos, que utilizam em demasia o computador, sem antes ter firmeza no desenho feito à mão livre ou até mesmo o realizado com instrumentos de desenho. As bibliotecas prontas existentes nos programas CAD são extremamente rígidas e sem expressão, não favorecendo a apresentação final do aluno. Notase, também, que somente os alunos que tiveram uma formação muito boa de desenho técnico conseguem passar estas informações para o computador, realizando um desenho com muita expressão e de qualidade, sem ser totalmente padronizado (A.S.F., 2002).

Por outro lado, na questão seguinte podemos notar, ainda que incipiente, essa busca de integração prancheta-computador:

Questão 7, bloco D:

No curso de arquitetura desta escola, o desenho em CAD é ensinado na mesma disciplina do desenho técnico arquitetônico tradicional (na prancheta)?

A essa questão, 45 professores responderam que "não", que o CAD é ensinado em outra disciplina. Um professor assinalou que o CAD não é ensinado em momento algum. Mas, seis professores alegaram que o CAD tem sido ensinado na mesma disciplina de desenho arquitetônico na prancheta.

No ano de 2002, como professor de desenho arquitetônico no CAU da EESC USP, fizemos uma experiência com os alunos do primeiro ano, que foi bem sucedida: ministramos (e não a professora da disciplina de Informática, cujo amplo programa inclui, além do CAD, textos, imagem, som, animação, WEB, multimídia etc.) o módulo de desenho arquitetônico em CAD, quando pudemos, com mais propriedade, assistir os alunos quanto à representação gráfica desta matéria, além de subsidiá-los nas especificidades próprias próprias destes sistemas $C A D$, que implicam novos saberes, novos conceitos etc.

Ainda que este procedimento pareça razoável e oportuno, novas implicações estão em jogo. Um professor respondente, por exemplo, comenta:

Com relação às questões de $C A D$, o curso é ministrado para alunos de primeiro ano e justamente pelo fato deles não terem 
ainda assimilado toda complexidade da representação técnica, as informações transmitidas quanto escala e equalização de cotas/ padrões de letras causam pouco interesse e por isso, penso, são facilmente esquecidas (L.R.S., 2002).

Acreditamos ainda estarmos nós mesmos numa fase de assimilação e adaptação, de aprendizagem, de experimentação desta nova ferramenta, até de eliminação de preconceitos. Cada tentativa é uma experimentação e necessita de acertos. No entanto, como os números registram, é de consenso que a prática do desenho arquitetônico no computador deva ter como condição uma razoável prática do desenho na prancheta, com instrumentos. Estas questões serão retomadas no bloco G.

Bloco E Metodologia

Neste bloco investigamos alguns aspectos de metodologia do ensino de desenho arquitetônico. Afere-se, por exemplo, até que grau de profundidade chegam algumas escolas e seus modos de avaliação do aprendizado do aluno. Questiona-se o modo de ensino de cotas e de desenhos de detalhes. A análise também nos confere, estimadamente, o grau de assimilação e interesse dos alunos para com esta matéria, a partir do que sentem os professores.

Iniciamos este bloco com uma questão prática quanto à forma da representação da força do traço, mais espessa e mais fina, nos desenhos com instrumentos, na prancheta:

No ensino tradicional (desenho na prancheta) acentua-se a importância de diferentes pesos de grafismo (linhas mais grossas para elementos mais próximos ou em corte e mais finas para o restante do desenho)?

Com relação a essa questão, 55 responderam "sim", sete não se manifestaram; e um respondeu que "não".

Antes de se constituir características de expressividade no desenho técnico, a diferenciação de traços obedece, antes, às regras do desenho técnico. Sem isto, seria difícil ou mesmo impossível de se ler um projeto, em planta ou em corte. Verificamos que este entendimento está claro para a maioria.

A questão dois reforça a primeira, no sentido do entendimento dos objetos que 
de um projeto arquitetônico:

Uma maquete (física) de um projeto de arquitetura em que fosse possível desmembrá-la nos seus planos de pavimentos e secções, não ajudaria o aluno a entender um desenho de corte (elementos em corte e em vista)?

Aqui, 41 responderam "sim"; e três assinalaram que "sim, mas pode-se mostrar também em fotos"; nove assinalaram "sim, mas pode-se mostrar também numa simulação de 3D de CAD”; e nenhum respondente escolheu a opção "não é necessário". Concluimos, portanto, que é um recurso válido. Um professor escreveu:

Utilizamos maquetes seccionadas para facilitar ao aluno a compreensão do que são plantas baixas, coberturas, cortes $e$ fachadas. Desde que começou-se a trabalhar assim, melhorou o resultado obtido (C.E.J.L., 2002).

Na questão 3:

Na disciplina em que se ministra o desenho técnico arquitetônico, o conteúdo abrange o desenho das paredes, em planta ou em corte, com alvenaria osso e linha de revestimento, a partir da escala 1:50?

Vinte e dois responderam "sim, sempre"; 11, "sim, a partir do momento em que constatamos que os alunos apresentam o traço mais preciso e seguro"; e 15 assinalaram "não". Dois professores escreveram que se utilizariam deste recurso somente num detalhamento, em escala ampliada.

As questões de quatro a sete indagam sobre o ensino da cotagem em desenho arquitetônico nas escolas de arquitetura.

Questão 4:

Ainda nesta disciplina (de desenho arquitetônico), até que nível se aborda a cotagem (dimensinamento)?

Três professores assinalaram que "as cotas não são tão importantes na formação de um arquiteto; o recém-formado acabará aprendendo imediatamente na prática profissional"; 24 responderam que se aborda a cotagem somente "até o nível de estudo preliminar (colocando-se somente algumas cotas); e 26, que "alcança-se o nível de projeto executivo".

Questão 5:

Numa possível aula sobre cotagem, comenta aos alunos da hierarquia das cotas (vãos e aberturas nas paredes, o espaço interno e as espessuras das paredes e, por fim, as cotas externas de uma edificação), sua correta locação, pertinência, casos especiais, etc.?

Nessa questão, 49 assinalaram "sim" e quatro assinalaram "não". 
Questão 6:

Comenta com os alunos das cotas funcionais (as cotas que efetivamente vão garantir a perfeita execução de algum detalhe ou locação da obra) ou quando é conveniente omitir uma cota para evitar uma interpretação ambígua?

Nessa questão, 44 assinalaram "sim" e nove assinalaram "não".

Na questão sete:

Comenta, ainda, que os eixos (com suas cotas, letras e números) das paredes (ou da estrutura) auxiliam a locação da obra e podem ser previstas já desde o desenho de arquitetura?

Aqui, 43 apontaram "sim" e nove apontaram "não".

Pelo menos dois professores acharam importante todas estas questões, mas alegaram que não há tempo suficiente para transmitir estes ensinamentos aos alunos.

As respostas dessas quatro questões apresentam, para nossa surpresa, números favoráveis às orientações corretas no ensino de cotagem em desenho arquitetônico, em contraposição ao que pudemos verificar, atuando na elaboração de diversos projetos executivos de arquitetura: os estagiários (de diversos anos) e alguns recém-formados não cotavam bem os desenhos.

A oitava pergunta segue a mesma linha de discussão, porém no campo dos detalhes e especificações:

E quanto ao desenho de detalhes e especificações, até que nível chega? a) Nível executivo, com especificações, cotas e tantos desenhos ampliados necessários, obrigando os alunos a pesquisarem junto a fornecedores/fabricantes; b) Nível médio, apenas a ciência da grandeza e viabilidade destes detalhes; c) Não é possivel ensinar os alunos a detalhar, por falta de mais horas/aula nesta disciplina; e d) Não chegamos a cobrar os detalhes, deixando que os alunos aprendam na vida profissional.

Responderam: 21, nível executivo; 17, nível médio; 14 alegaram que a falta de mais horas/aula impossibilita ensinar os alunos a detalhar; e apenas um assinalou o item "d".

Os números remetem, mais uma vez, a patamares positivos. Surpreende-nos, pelo menos na escola de São Carlos, que a maioria dos alunos não têm traquejo suficiente para lidar com os desenhos de detalhes, que são solicitados nos trabalhos finais de graduação. Esta falta de prática é devida, entre outros fatores, pelo pouco que foi ensinado a eles, pelo fato de haver um número mínimo de horas-aula de desenho arquitetônico. Também nós, em participação de bancas finais de graduação em outras escolas, deparamo-nos, muitas vezes, 
com dificuldades dos alunos quanto à representação mínima dos desenhos de arquitetura; e, possíveis detalhes de algum elemento construtivo interessante a se mostrar nem existiam.

Questão 9:

Transmite aos alunos a importância da eficiente comunicação entre os desenhos, as chamadas de detalhes perfeitamente endereçadas, desenhos que continuam em outras pranchas, desenhos-legenda de identificação do edifício em questão, a correta numeração das pranchas etc.?

Nessa questão, 50 professores assinalaram "sim" e quatro, "não". Cinco não se manifestaram.

Esta questão trata da "comunicação interna" entre os desenhos. Diferentemente de um texto, cujo raciocínio exposto é seguido linearmente, os desenhos e as informações à disposição constituem - segundo afrima DEFORGE (1981, p.13) e como já havíamos comentado no primeiro capítulo - uma espécie de memória morta. Todas as informações são co-presentes sobre a superfície desenhada, sem uma ordem preferencial imposta. Não há leitura linear, mas sim consulta. Os processos de consulta dependem daquele que procura aquilo que consulta.

Reparamos, não poucas vezes, na nossa experiência como docente, que os alunos, tão entretidos ("viciados") com seu projeto, não percebem esses pequenos detalhes de "ligação" entre os desenhos, como por exemplo: Corte AA, na folha 2; Detalhe 2, na folha 4, Ver tabela na folha 3 etc. Isso talvez ocorra porque os alunos, sempre presentes, expõem verbalmente aos professores que assistem à sua exposição. Mas, na entrega desses desenhos para nota (ou numa exposição), professores (ou outras pessoas) que nunca viram o projeto sentem falta destes pequenos detalhes da "boa comunicação". Este treino, desde a escola, permitirá que suas idéias, veiculadas através de desenhos e textos, "falem por si só", sem que exijam sua presença para complementar as explicações ou localizar, para os outros, a seqüência dos desenhos. Portanto, a nosso ver, os números registram uma certa contradição.

As questões 10 a 12 indagam:

10. Sabendo que o desenho técnico arquitetônico é uma antecipação da obra construída, realiza visitas às obras com os alunos ou, pelos menos mostra, de alguma forma, as fases de construção e detalhes de obra?

As respostas se dividiram, quase que equilibradamente: 25 "sim" e 27 "não". Dois ou três alegaram que os professores de Projeto é que levam os alunos para visitar obras. 
fases construtivas, dos elementos estruturais, de fechamento, acabamento, materiais, etc. - nenhuma linha é gratuita (desenhar uma linha pela linha em si), mas deve ser representação do material (alvenaria, concreto, piso acabado, um material etc.). Até o final da disciplina, quantos alunos têm consciência do que estão desenhando?

Menos de 30\%: quatro; de 30 a 50\%: 14; de 50 a 70\%: 20; e 13 assinalaram que mais de $70 \%$ dos alunos têm consciência do que estão desenhando.

12. Num desenho de corte, os alunos sabem representar [quando for o caso] distintamente os elementos alvenaria, vigas e lajes?

Aqui, 43 responderam "sim" e seis responderam "não".

Este conjunto de questões (de 10 a 12) investiga, uma vez mais, a preocupação de que os alunos saibam, realmente, o que estão desenhando. Devem desenhar o material, que "monta" a estrutura do edifício (lajes, colunas, vigas), ou que cobre (envolve todo o sistema construtivo: tesoura, terças, caibros, sarrafos, telha etc.), veda (os fechamentos com os seus dispositivos e sistemas para tal), ou reveste esse edifício etc. Este materiais têm "começo, meio e fim"; logo, são polígonos fechados (se os representarmos em desenho), seccionados ou em vista; são de madeira, ou de barro, de concreto, metal etc. Portanto, o aluno não pode desenhar uma linha pela linha em si - é gratuito, não faz sentido; antes, isso atesta de que não sabe o que está desenhando -, mas, sim, a representação do material.

O professor de desenho arquitetônico deve, então, pelo menos, ilustrar suas aulas com exposição de imagens de obra, em suas várias etapas. Seria enganoso ensinar desenho arquitetônico somente de forma conceitual, projetual, em que organizamos os espaços, as relações volumétricas, as proporções etc., mas sem nos fixarmos, também, na materialidade do projeto arquitetônico. Os professores de Projeto, em obra com os alunos, além de mostrar-lhes os aspectos que lhes competem na suas disciplinas, devem despertar nos alunos a atenção aos detalhes construtivos, à fatura da obra em si.

Apesar de os números registrarem uma estimativa otimista, uma atenção regular e revista, em trabalho conjunto com os professores de Projeto e Tecnologia, ajudará a manter essa cultura em dia: quanto mais cedo os alunos absorverem estas informações, melhor, e trará bons resultados nos trabalhos finais de projeto dos alunos do último ano.

Os professores que sentem que a maioria de seus alunos não sabem o que estão desenhando, devem reavaliar seus métodos de ensino, procurando diminuir 
essas deficiências.

Questão 13:

Incentiva os alunos a visitarem a biblioteca para consultarem revistas de arquitetura, em que aparecem distintos modos de representação de desenhos de arquitetura?

Dos respondentes, 49 assinalaram "sim"; quatro, "não".

Os livros e revistas que tratam da arquitetura trazem consigo, sempre, os desenhos que a representam. Não importando a idade destes materiais, são fonte inesgotável de repertório dos diferentes modos de representação gráfica arquitetônica, seja com desenhos de plantas, cortes e vistas, ou com desenhos axonométricos ou perspectivos. Concomitantemente, ou até antes, todos sabemos, estamos enriquecendo a nossa base de dados de espaços arquitetônicos interessantes, lendo as plantas e vistas e confirmando-as nas fotos, para extrair conclusões da espacialidade, relações volumétricas, proporções pretendidas pelos autores, vistas apreendidas pelas aberturas nas paredes, cores e texturas dos materiais, comportamento da luz, soluções de implantação no terreno etc. Observar essas revistas também é aprender arquitetura.

As publicações trazem, quase sempre, em escala reduzida, desenhos mais simples e sem textos (no máximo números e legenda dos ambientes). Estes desenhos simplificados já foram, quando da viabilização da obra, documentos carregados de cotas, textos, especificações, detalhes etc. Depois de executada a obra, apenas informam, quase que conceitualmente, a essência dos espaços agenciados. É como se fossem o resumo das intenções do autor arquiteto. Apesar de simples desenhos, são apresentados de maneiras diferentes: nós que os vemos, que praticamos a visita freqüente aos livros e revistas, conquistamos posição de vantagem em relação aos outros.

A atenção deve ser dada, também, às revistas mais dirigidas à obra, aos detalhes construtivos de estrutura, fechamentos, cobertura, ou a como apreender novas tecnologias de materiais e de construção etc.: revistas Detail, Finestra, Obra e outras.

Os números são otimistas e os professores devem, cada vez mais, incentivar seus alunos a irem às boas revistas de arquitetura e construção, fonte de repertório, além de se inteirar sobre o que acontece no mundo da arquitetura. 
As duas questões seguintes pretendem explorar o "desenho" do desenho, sua composição na folha, se chama a atenção (ou não) aos olhares, as preocupações com a diagramação, densidade etc.

14: É transmitida aos alunos certa preocupação em diagramação visual dos desenhos numa folha?

Quarenta e nove respondentes apontaram "sim"; quatro, "não".

15: Como estudado em linguagens visuais, nossa visão faz uma primeira e rápida leitura de um desenho (no nosso caso, uma prancha de desenho), ainda de longe, de manchas, pesos, leveza, contraste, ritmo, fundo-figura, posicionamento no campo visual, etc. Depois, sim, mais de perto, do conteúdo que este desenho quer informar. Explora, com os alunos, estes recursos, já que um desenho técnico também pode ser bonito, bem apresentado?

Aqui, 40 assinalaram "sim"; 10, "não"; e dois escolheram "outro modo", mas não explicaram como.

As preocupações com desenhos bem traçados, nas espessuras corretas: a precisão das medidas e suas posições; as especificações através de textos; a eficiente "conversa" entre os desenhos; tudo isso deve viabilizar que todo este conjunto, do desenho arquitetônico, desempenhe a função de comunicar algo a outro. Tais preocupações devem ser acompanhadas do cuidado visual dessas apresentações, reforçando (nunca atrapalhando) a comunicação desejada. Um desenho técnico deve ser objetivo, "frio", isento de erros etc., mas, pode e deve ser, também, bonito, agradável e atrativo. É própria do arquiteto a preocupação com a forma, com as proporções, com a comunicação visual e com a composição, e deve investir esforços neste sentido, visando, sempre, à boa apresentação do gráfico-papel - ou nas telas multi-mídias -, na comunicação oral e na obra concretizada. Esta preocupação é assinalada pela maioria dos respondentes.

Por fim, as duas últimas questões do bloco $\mathrm{E}$, que se referem à avaliação do aprendizado do desenho arquitetônico e ao grau de maturidade e comprometimento com que os alunos apreendem estas informações e as aplicam.

16: Como avalia o aprendizado do aluno em desenho técnico arquitetônico?

Vinte responderam "através de exercícios em sala e extra-sala"; sete, "através de exercícios-prova em sala de aula"; e 23, dos dois modos anteriores.

Os números conferem uma predominância do fato de os professores avaliarem o desempenho de seus alunos por um processo continuado e de acompanhamento. É importante um número razoável de horas-aula, em que 
os professores possam acompanhar o desenvolvimento dos alunos e dirimir suas dúvidas. Só não chegamos a uma conclusão mais consitente devido ao prejuízo, já comentado, das primeiras questões do bloco $C$, sobre as relações entre horas-aula e professores e seus auxiliares.

17: Poderia estimar a falta de maturidade, desinteresse, responsabiblidade e não comprometimento dos alunos no aprendizado do desenho técnico arquitetônico?

Vinte e três professores estimam que menos de 20\% dos alunos apresentem essas características; 22 professores estimam que a porcentagem é de 20 a 50\%; cinco estimam "de 50 a 70\%"; e dois professores assinalam "mais de 70\%" dos alunos. Dos 59 professores, sete não se manifestaram.

Entre os vários fatores que denunciam este quadro, está o de como nós, professores, encaramos esta matéria e sua conseqüente preparação, atuação em sala, modo de ensinar, que recursos utilizamos etc. É verdade que qualquer pessoa aprende melhor, com todas as forças, quando efetivamente precisa. Uma integração entre os professores de Desenho Arquitetônico, os de Projeto e também os de Tecnologia, em que estes últimos cobrem de seus alunos, sistematicamente, a correta representação gráfica de seus trabalhos, poderão resultar em maior comprometimento, interesse e responsabilidade dos alunos em aprender, desde já, o desenho arquitetônico. Acreditamos que é natural que os professores de Projeto cobrem de seus alunos a correta representação gráfica de seus trabalhos e que isso valha, até, parte da nota-avaliação. Porém, é desejável uma "postura" de que estes auxiliem, efetivamente, na complementação do ensino de desenho arquitetônico, já que há cada vez menos horas-aula para isso.

Bloco F Os desenhos e o canteiro de obras

As sete questões deste bloco querem averiguar a interface desenho-obra.

1: Informa aos alunos que as pranchas de desenhos executivos que se destinam à obra devem, na medida do possível, ter tamanhos pequenos (não grandes formatos) para facilitar sua consulta?

Trinta e dois assinalaram "sim" e 18, "não".

2: Comenta com os alunos que não é conveniente colocar desenhos de plantas de dois ou mais pavimentos na mesma prancha, pois serão executados em tempos diferentes e o documento papel não resistirá às intempéries e às condições da obra? 
Trinta e um escolheram "sim", 19, "não".

3: Comenta também que, na medida do possível, os desenhos de detalhes ampliados devem se apresentar na mesma prancha que os originaram, para facilitar sua consulta?

Trinta e dois "sim" e 18, "não".

4: Comenta com os alunos que é preciso separar desenhos de fornecedores diferentes (serralheria, marcenaria, etc.), pois se apresentariam como "ruídos", não pertinentes, a não ser que façam parte de um mesmo conjunto de soluções?

Vinte e oito indicaram "sim", 21 indicaram "não".

5: Os alunos aprendem que, o contato direto com os fornecedores e representantes de material de construção, é conveniente para não perderem tempo com exaustivos detalhamentos que possivelmente os fabricantes já pensaram e resolveriam melhor?

Trinta e três, "sim" e 18, "não".

6: Acredita que, se os alunos visitassem regularmente uma obra ou acompanhassem a sua locação, aprenderiam mais rápido a cotar corretamente um desenho de arquitetura?

Quarenta e sete apontaram"sim", cinco apontaram "não".

7: Comenta também sobre o cuidado de saber controlar as sucessivas emissões de um mesmo desenho que sofre várias modificações, certificando-se de que o empreiteiro ou outro profissional está com a emissão mais recente?

Vinte e sete responderam "sim" e 23 respoderam "não".

Verticalmente, sete professores não responderam a nenhuma dessas sete questões; 11 professores responderam "sim" a todas; e dois professores responderam "não" a todas.

Calorosas discussões sobre o afastamento do arquiteto do canteiro, sob diversos aspectos, todos importantes, estão documentadas em livros, dissertações e teses. No cotidiano da construção estas conversas também surgem e, muitas vezes, em tom pouco favorável ao lado do arquiteto ou desenhista.

Preocupa-nos que há um número considerável de respostas negativas. A nosso ver, é preciso resgatar a atença à obra, ao edifício, sem deixar outros ensinamentos que certificarão a formação de um arquiteto. Os arquitetos, em sua grande maioria, pretendem projetar e construir. Não é, pois, no contato com a obra, mesmo que não tão intenso, que o objeto mesmo do seu "fazer", a concretização de suas propostas, terá o retorno de tudo que pensou, documentado em peças gráficas, na forma de desenho técnico arquitetônico? Não é ali que conferirão a fidelidade dos desenhos, tirarão conclusões práticas, 
extrairão experiências que melhorarão seus desenhos, visualizarão espaços nunca pensados, e poderão até propor alterações "in loco", junto aos clientes? Não seria este, também, um grande campo de aprendizado de desenho e da própria arquitetura?

Bloco G Sobre o CAD

Quando da elaboração deste questionário, resolvemos abranger o CAD nas reflexões sobre o desenho técnico arquitetônico, pois esta ferramenta se faz presente, cada vez mais, nas apresentações dos trabalhos acadêmicos dos alunos. Com seu uso cada vez maior em todas as áreas e o barateamento e popularização do computador, os sistemas CAD participam, numa condição quase irreversível, nos processos de produção da arquitetura.

As questões se subdividem em três etapas: operacionais; de opinião; e sobre os aspectos importantes do desenho na prancheta $x$ computador.

Seguem as primeiras cinco questões, do tipo operacionais, com seus resultados:

1. É utilizado algum sistema $C A D$ no ensino de desenho técnico arquitetônico?

Quarenta e dois respoderam "sim"; oito, "não"; e nove não se manifestaram.

2. Se a resposta anterior é afirmativa, que programa [software] de CAD utilizam? (múltipla escolha)

Os que utilizam somente um programa somam 20, sendo que:

Dezessete utilizam somente o "Autocad"

Um, somente o "Minicad" (hoje, VectorWorks)

Um, somente o "DataCad"

Um, somente o "Microstation".

Dos que assinalaram mais de um programa:

Oito adotam "Autocad" + "Arqui_3D"

Um adota "Autocad" + "Arqui_3D" + "3D Studio"

Três adotam "Autocad" + "Arqui_3D" + "ArchCad"

Um adota "Autocad" + "Arqui_3D" + "ArchCad" + "3D Studio"

Um adota "Autocad" + "Arqui_3D" + "Minicad"

Um adota "Autocad" + "Minicad" 
Um adota "Autocad" + "Minicad" + "Microstation"

Um adota "Autocad" + "Minicad" + "ArchCad" + "3D Studio" + SketchUp"

Um adota "Autocad" + "Arcad" (desenvolvido pelo professor Aristóteles

Cordeiro, da UFPb)

Um adota "Autocad" + "FormZ"

Um adota "Autocad" + "FormZ" + "Microstation"

Dois adotam "Autocad" + "Microstation"

Em quantidades absolutas:

Trinta e nove utilizam o "Autocad"

Quatorze utilizam o "Arqui_3D"

Cinco utilizam o "Minicad"

Dois utilizam o "FormZ"

Um utiliza o "DataCad"

Cinco utilizam o "Microstation"

Nenhum dos que responderam utilizam o "ArCom", da Pini; ou o Catia, da IBM.

Percebemos que há notadamente uma preferência pelo "Autocad", da Autodesk - um dos primeiros programas de CAD que chegaram ao Brasil, além de facilmente ser encontrado em muitas máquinas. Este programa é detentor, todos sabemos, da maior base instalada no país, entre profissionais arquitetos, calculistas, topógrafos, instaladores etc. Esta constatação faz com novas pessoas aprendam a operar nele e desestimula que busquemos outros programas.

Aparece, em segundo lugar, o "Arqui_3D", da mesma empresa, que funciona, porém, dentro do "Autocad". Os outros são utilizados em quantidades bem menores, não estão sozinhos, na maioria das vezes. Acreditamos que contitua postura saudável de algumas escolas procurar novos experimentos, no sentido de constatar que há outras opções de programas CAD, para desenhos de arquitetura.

Quanto aos programas escolhidos, sem dúvida as escolas refletem o que acontece no mercado. As outras possibilidades de programas contempladas, ainda que em menor número, estão ganhando força, pois suas lógicas são mais interativas com o usuário que o "Autocad", cujos procedimentos de comando são mais diretos e simples. 
Apesar de os números constatarem que a plataforma PC (IBM, Personal Computer) lidera disparadamente, há um pensamento, quase unânime, no campo profissional, de que a plataforma Mac (Macintosh, da Apple Computer) é melhor para trabalhos gráficos, apesar de a indústria do PC concentrar esforços para diminuir esta diferença.

O sistema operacional do Mac, além de mais seguro e confiável, é mais interativo e utiliza uma lógica mais fácil de usar, além de ser bem menos vulnerável a vírus. Mas, além destes fatores e muitos outros, existe um valor agregado que é o design, o que o faz um pouco mais caro. No entanto, a longo prazo, constitui-se numa máquina que exige menos manutenção; que executa novos sistemas operacionais, bastando para isso, na maioria das vezes, acrescentar somente mais memória.

Talvez seja a FAU/Mackenzie a primeira a utilizar a plataforma Mac em arquitetura. Mas, muitas outras universidades e centros de estudos adotamna, em seus cursos de Design, Design Gráfico, Multimídia, Fotografia, Artes Plásticas, Jornalismo, Propaganda, Publicidade, Comunicação Visual, Cinema

${ }^{3}$ Fonte: Revista Macmania, n.105, Março 2003, p.13. São Paulo, Bookmakers, 2003. etc. ${ }^{3}$ Novas iniciativas, ainda incipientes, a partir de professores em escolas de arquitetura, estão surgindo, como é o caso dos CAU USP (São Carlos e UFMG).

4. No ensino de desenho técnico arquitetônico no $C A D$, qual é a relação de número de computadores/aluno?

Nessa questão, 28 professores responderam "um computador por aluno"; 13, "um computador para cada dois alunos"; e três responderam "um computador para cada três alunos".

Os números identificam que a tendência é que haja um computador por aluno, o que, certamente, assim como na prancheta, é o ideal.

5. Há horários livres [extra-classe] para que os alunos possam utilizar os computadores?

Quarenta e dois responderam "sim" e três, "não".

Qualquer técnica transmitida exige treinamento e prática. As escolas devem viabilizar o treinamento de seus alunos não só em $C A D$, como também em todos os outros programas, através de laboratórios especialmente montados para esta finalidade. Os números, felizmente, registram isto. Um outro fator, que não foi, infelizmente, contemplado no questionário, é quanto às 
atualizações (up-grades) regulares da performance dos micro-computadores e periféricos.

As respostas das quatro questões seguintes nos fornecem um panorama sobre o que opinam estes professores em relação aos computadores x prancheta.

6. Com o advento do computador, na sua opinião, faz-se necessário ensinar desenho técnico arquitetônico na prancheta?

Quarenta e quatro assinalaram "sim"; nove "não"; seis respondentes não se manifestaram.

7. Na sua opinião, não seria desejável que o ensino/método permitisse ao aluno elaborar um desenho técnico arquitetônico direto no computador?

Vinte e quatro responderam "sim"; 26, "não"; quatro responderam "talvez, mas não saberia como"; e cinco não se manifestaram.

A pergunta é bem clara: direto no computador. Há um peso, quase equilibrado entre o "sim" e o "não", reflexo, ainda, de se ensinar primeiramente o desenho na prancheta, como sugerem, favoravelmente a esta opinião, os números das respostas da questão anterior.

Uma professora, no final do questionário, escreveu:

$\mathrm{Na}$ pergunta sete do bloco $G$, senti dificuldades de responder uma vez que, na disciplina de CAD, já é elaborado um desenho técnico completamente no computador. Uma questão relevante não foi levantada, assim como os detalhes já elaborados pelos fornecedores, hoje existem os blocos de CAD disponíveis nos seus sites. Como professora das duas disciplinas, tenho observado um fenômeno que merece ser apontado, em casos em que o professor não recebe desenhos executados em CAD: os alunos, mesmo dos primeiros períodos, executam e imprimem os desenhos em CAD para depois passar por cima, no papel manteiga. Atualmente, por este e outros acontecimentos, como o ingresso prematuro aos estágios, está se estudando retirar a computação gráfica dos primeiros períodos (T.A., 2002).

É oportuno registrar, novamente, o que um dos professores escreveu, quando da questão seis, do bloco D:

Deixo registrado que todo o tipo de desenho deve, antes, ser aprendido adequadamente anterior à utilização da computação gráfica. Pois, o que se nota é uma dificuldade crescente em relação à representação dos alunos que utilizam em demasia o computador sem antes ter firmeza no desenho feito à mão livre ou até mesmo o realizado com instrumentos de desenho. As bibliotecas prontas existentes nos programas CAD são extremamente rígidas e sem expressão, não favorecendo a apresentação final do aluno. Notase, também, que somente os alunos que tiveram uma formação muito boa de desenho técnico conseguem passar estas informações 
para o computador, realizando um desenho com muita expressão e de qualidade sem ser totalmente padronizado" (A.S.F., 2002).

${ }^{4}$ Professor Admir

Basso, do CAU da Escola de Engenharia de São Carlos/USP.

5 SEGAWA, Hugo; DOURADO, Guilherme Mazza (1997). Oswaldo Arthur Bratke. São Paulo: ProEditores, páginas $50,80-81$.
Não podemos deixar de registrar o que um colega professor ${ }^{4}$ comentou, certa vez, quando analisava os desenhos de seus alunos. Dizia ele que as facilidades e customizações do CAD possibilitavam aos alunos inserirem numa parede, em segundos, uma bibloteca pronta de uma janela. Mas, alegava ele, essa facilidade desobrigava-os de refletir (ou desfavorecia sua reflexão) - assim pressentia - sobre o "projeto" da janela, suas dimensões, vãos, número de folhas, modo de abrir, que material é ... etc. Em contraposição, lembramos, agora, dos exautivos desenhos, em croquis, de uns caixilhos que o arquiteto Oswaldo Bratke desenvolvia num de seus projetos ${ }^{5}$.

Pelas respostas e manifestações de alguns professores, prevalece o zelo pelo desenho, antes, na prancheta, ao invés de no computador diretamente. Além dos aspetos da expressividade do desenho, elaborado com mais desenvoltura no computador se, antes, o aluno praticou (e muito) na prancheta, o CAD traz recursos - como o das bibliotecas prontas - que vão contra o aprendizado do aluno, pelo menos nesses primeiros momentos de sua formação, pois, talvez, ainda não compreendam, de todo, o que esses desenhos prontos representam. 0 fato de os alunos imprimirem um desenho para, depois, passá-lo à mão, é uma atitude que deve ser evitada, se está em jogo a busca da precisão do traço nos desenhos com instrumentos.

8. Na sua opinião, em desenho técnico arquitetônico, o CAD vai eliminar as pranchetas?

Dez responderam "sim, radicalmente"; 29, "sim, a partir de uma determinada fase do projeto (a partir do Anteprojeto), sendo que um deles alega que poderia ser já a partir do Estudo Preliminar; 16 responderam "não"; e quatro não se manifestaram.

\section{E em Projeto, CAD vai eliminar as pranchetas?}

Dez responderam "sim"; 28, "não"; 16, "talvez, desde que haja programas mais adequados para criação); e cinco não se manifestaram.

As estatísticas destas duas últimas questões, a nosso ver, registram que a opinião sobre o uso do CAD - pelo menos o que mais usamos - é de que cumprem bem sua função somente a partir da finalização do processo de criação/ concepção de um projeto. Estas primeiras ações, do lápis sobre o papel, e depois, sim, no computador, predominam nas opiniões dos respondentes. Há, porém, um número considerável deles (16 professores) refletem sobre a 
possibilidade de se fazer projeto, diretamente no computador, se existirem programas apropriados para isto.

Por último, as questões de dez a 14 procuram resgatar alguns aspectos importantes do desenho na prancheta que devem estar presentes, também, nos desenhos elaborados em CAD.

10. Como no ensino tradicional na prancheta, acentua-se também no CAD a importância de diferentes pesos de grafismo (linhas mais grossas para elementos mais próximos ou em corte e mais finas para o restante do desenho)?

Quarenta e seis, "sim"; 3, "não"; e dez não se manifestaram.

11. Ainda sobre este assunto, os alunos percebem que as espessuras aplicadas num desenho 1:50 devem ser diferentes num desenho 1:200 ou menor?

Trinta e três, "sim"; 15 "não"; e 11 não se manifestaram.

12. Ainda nesta linha de pergunta, os alunos têm a sensibilidade de adotar diferentes tamanhos de letra para se adequar a diferentes escalas de desenhos a serem plotados?

Trinta e cinco,"sim"; 13, "não"; e 11 não se manifestaram.

13. Em Autocad ou outro programa similar, os alunos configuram corretamente os elementos de cotagem (linhas de cota, linhas auxiliares, de extensão, tamanho adequado da letra etc.)?

Trinta e quatro, "sim"; 13, "não"; e 12 não se manifestaram.

Estes números registram, felizmente, que estas preocupações estão sendo contempladas, na maioria dos respondentes, também no CAD. No entanto, é preciso, ainda, que mais professores se conscientizem disso, pois constituemse em aspectos do campo da expressividade, de possibilitar a boa leitura etc. Verificamos que, na condição de professor de desenho arquitetônico, a experiência aqui já relatada, de ministrar as aulas de CAD no lugar do professor de Informática, trouxe melhores resultados também quanto a estes aspectos de espessuras de traço, tamanhos de textos etc. E, nos atendimentos aos trabalhos finais dos alunos do último ano, temos falado sobre essas mesmas preocupações.

14. Em CAD, os alunos têm consciência da importância das camadas de desenho (no Autocad chama-se "Layer"; no Vector, "Classes")?

Quarenta e quatro, "sim"; cinco "não"; e 10 não se manifestaram.

A separação criteriosa em níveis ou camadas de desenhos constitui-se num dos grandes diferenciais dos sistemas CAD, possibilitando, oportunamente, visualizar ou não ("congelar") alguns elementos do projeto. As respostas apresentam números favoráveis à atenção a este item de comando dos sistemas CAD. 
No primeiro capítulo deste trabalho abordamos este assunto. E, nessa questão, um professor, atento a esta preocupação, nos escreveu:

A ASBEA (Associação Brasileira de Escritórios de Arquitetura) divulgou recentemente um manual para normatizar a troca de arquivos eletrônicos de CAD entre as diversas equipes profissionais envolvidas num projeto. Ele diz respeito principalmente à configuração e à nominação dos "layers" dos desenhos, tendo sido concebido independente de plataforma ou software. Conviria avaliar sua eficácia (não se identificou, 2002).

Esta preocupação deve ser fortemente transmitida ao aluno. Podemos não ensinar, com toda profundidade, este ou aquele programa de CAD, pois não se trata de a Universidade instrumentalizar o aluno, mas este conceito - dos "layers" ou camadas de desenhos - deve ser transmitido. Relata o autor que, em atendimento a alunos de outros anos, tem procurado, insistentemente, falar deste critério e de seu uso correto. $\mathrm{O}$ autor também relata que os novos estagiários que chegavam em seu escritório, mal sabiam utilizar corretamente este recurso no desenho arquitetônico em CAD.

\section{Bloco H} Finalmente ...

Este conjunto de questões finaliza este questionário. São questões do tipo: o que pensam os professores, o que já publicaram no assunto de desenho arquitetônico ou CAD, se participam ou dirigem algum grupo de pesquisa nesta área etc. Pretendemos, sobreturo, com este último bloco, manter contatos com estes professores, cuja participação foi valiosa, e dar-lhes retorno dos resultados analisados.

1.Faz falta um manual / apostila / livro de desenho técnico arquitetônico mais atualizado no Brasil?

Cinqüenta responderam "sim"; quatro "não"; e cinco não se manifestaram.

Acreditamos ser entendimento da maioria que um manual auxiliaria, como leitura básica e complementar, no ensino de desenho arquitetônico e que carecemos - os números assim atestam - de um manual mais atualizado, que contemple também as questões de CAD, além de abordar, 
efetivamente, a representação gráfica da materialidade dos elementos da construção de um edifício.

2. Você já publicou algo sobre o assunto (apostila, manual, artigo, dissertação de Mestrado, tese de Doutorado)?

Quarenta e cinco professores responderam "não"; oito, "sim"; e seis não se manifestaram.

3. Se sua resposta é afirmativa, escreva (s) referência(s) bibliográfica(s):

Dos oito que assinalaram "sim" na questão anterior, sete escreveram o que publicaram.

1. Prof. Jônio Cintra e Oliveira, da FAU UnB, Brasília:

Manual interno da escola.

2. Prof. Mário Lúcio Pereira Junior, do Departamento de Arquitetura e Urbanismo da PUC Minas Gerais, Belo Horizonte:

a) A modelagem tridimensional informatizada: um instrumento de ensino de projeções ortogonais em arquitetura. Florianópolis, 2001. 121p. Dissertação (Mestrado Engenharia de Produção) - Programa de Pós-Graduação em Engenharia de Produção, UFSC, 2001.

b) Uma Reflexão sobre a Informática na Representação Gráfica da Arquitetura. Cadernos de Arquitetura e Urbanismo, PUC MG, Belo Horizonte, v.6, n.6, p.124-136, dez.1998.

c) Informática na Representação Gráfica da Arquitetura. In: SEMINÁRIO NACIONAL A INFORMÁTICA NO ENSINO DA ARQUITETURA, 2, 1996, Viçosa. Resumo, Painel e Conferência... Viçosa: UFV, 1996.

d) Materialidade no Projeto de Arquitetura. Cadernos de Arquitetura e Urbanismo, PUC MG, Belo Horizonte, v.8, n.9, p. 177-193, dez.2001 (em conjnto com os autores M. M. Silva e R. E. Santos).

3. Prof. Mauro César Pereira, da UniAndrade, Curitiba:

Manual Técnico de de Construção para Corpos Afiliados da AMORC-GIB.

4. Prof. Orlando Pinto Ribeiro, do CAU UnicenP (Positivo), Curitiba:

CIBERESPAÇO PROJETUAL: Uma abordagem crítica sobre a representação digital no processo projetual da arquitetura. Dissertação de Mestrado.

5. Prof. Paulo Chiesa, do Departamento de Arquitetura e Urbanismo, da UFPR, Curitiba: 
O Desenho como Desígnio: por uma ética do risco. Tese de Doutorado. Faculdade de Arquitetura e Urbanismo, USP. São Paulo, 2001.

6. Prof. Marion Divério Faria Pozzi, da Faculdade de Arquitetura/Departamento de Expressão, da UFRGS, Porto Alegre:

Perspectiva e sombra. Porto Alegre: DEG/UFRGS,2001 (encontra-se na BIB ARQ/UFRGS; na internet, www.sabi.ufrgs.br.), em conjunto com Doris $M$. Bittencourt.

7. Prof. Sérgio Leal Ferreira, da Escola Politécnica da USP, São Paulo:

a) Participação na tradução do livro: GIESECKE, F. E. Comunicação Grafica Moderna. Porto Alegre, Bookman, 2002.

b) Estratégias de solução de Problemas Espaciais: uso criativo do CADD no ensino In: Graphica 2000, 2000, Ouro Preto.

c) STEP E MERODE como esforços por criar uma descrição útil ao CAAD dos elementos do Projeto Arquitetônico e das suas relações. In: 15 Simpósio Nacional de Geometria Descritiva e Desenho Técnico, IV International Conference on Graphics Engineering for Arts and Design, 2001, São Paulo.

Na continuidade desta trabalho, temos a intenção de ler essas publicações e de identificar não somente pontos em comum, como também novas idéias que poderão enriquecer esta pesquisa em prol do bom ensino de desenho arquitetônico.

4. Possui ou participa de algum grupo de pesquisa em desenho arquitetônico ou desenho de arquitetura em geral?

Cinqüenta responderam "não"; três, "sim"; seis não se manifestaram.

Embora alguns professores tenham exposto o que já publicaram, consideramos, dentre todos os respondentes que há, pouca produção científica e poucas pesquisas ou grupos de pesquisa na área de desenho arquitetônico ou desenho de arquitetura em geral. Parece ser uma área esquecida por muitos, dentre tantos outros conhecimentos a serem transmitidos aos alunos. No entanto, há um vasto campo ainda a ser explorado, sobretudo em conjunto com as áreas de CAD, de Projeto e Tecnologia, tendo o desenho como mediador destas interfaces.

5. Se sua resposta à questão anterior é afirmativa, informe o nome do grupo, e-mail, site ou qualquer outra identificação para que possamos entrar em contato:

Dois deles escreveram:

A Profa. Christina Araujo Paim Cardoso, da Faculdade de Arquitetura da UFBA, 
Salvador desenvolve pesquisa para sua tese de doutorado vinculada à lista da pesquisa "Linguagem, Informação e Representação do Espaço", do PPG-AU. E-mail para o coordenador: alamorim@ufba.br

O Prof. Orlando Pinto Ribeiro, do CAU UnicenP (Positivo), Curitiba, escreveu que coordenará um Curso de Pós-graduação (especialização), a partir de 2003, na área de Ciberarquitetura: Expressão e representação digital em arquitetura.

6. Tem observações a fazer?

Mais do que uma questão, este item do questionário é um espaço aberto para os professores complementarem alguma resposta do questionário, fazer comentários, expor o que pensam, dar sugestões, fazer críticas a este trabalho etc. Escreveram-nos comentários de várias naturezas. Algumas observações já foram citadas ao longo da análise deste questionário, pois eram oportunas em reforçar ou contextualizar as respostas dos professores. Das principais observações que aqui registramos, tentamos agrupá-las por temas. São elas:

> Material didático, a área de desenho:

A partir de referências bibliográficas e da minha própria experiência profissional, elaborei uma pequena apostila resumida dos assuntos abordados na disciplina, para a consulta dos alunos, mas não chegou a tornar-se uma publicação. As referências foram: Desenho arquitetônico, de Gildo Montenegro; Manual de construção de escadas, de Caio de M. Franco; Elementos e Normas para desenhos e Projetos de Arquitetura, de Nilson Tech; Código de Obras de Maceió; e Transporte vertical nos edifícios (M.V.S., 2002).

O Departamento está implantando uma reestruturação das disciplinas de Desenho Técnico e Geometria, que passam a ser denominadas Expressão Gráfica, e a chefe do Departamento, Profa. Elisabete, irá enviar para vocês um e-mail informando sobre estas modificações, com programas e o cronograma de implantação (C.A.P.C., 2002).

Abrangemos o estudo do desenho em todas as suas dimensões na Arquitetura da UFRGS, porque temos um departamento dedicado a expressão gráfica com nove disciplinas que tratam exclusivamente de desenho, seja o técnico ou expressivo, totalizando uma carga horária mínima (obrigatória) de 405 horas (M.D.F.P., 2002).

1. Utilizamos maquetes seccionadas para facilitar ao aluno a compreensão do que são plantas baixas, coberturas, cortes $e$ fachadas. Desde que se começou a trabalhar assim, melhorou 
o resultado obtido. 2. As respostas de cad são baseadas em observação, já que não ministro esta disciplina. 3. Trabalho com a distribuição dos elementos (cortes, plantas, fachadas, detalhes) na prancha mas não entro na questão de ver de longe ou perto. Para isto existe uma das disciplinas de desenho, que trabalha especificamente estes elementos. 4. Não é possível aprofundar a parte de detalhamento porque o tempo é pouco (C.E.J.L., 2002).

Estou no último ano do curso de AU da UNIMEP. Percebo que até hoje há dificuldades em minha turma sobre as formas de representação técnica, e esta deficiência é corrigida pelas disciplinas de projeto. A disciplina de desenho técnico não atua em conjunto com outras disciplinas de representação" (um aluno que não se identificou, 2002).

$>$ Desenho e CAD:

Minha opinião é de que se deva ter duas disciplinas para o ensino do desenho de representação, uma que dê todas as informações necessárias à abrangência do conteúdo e das normas e seja também prática (prancheta), para tentar unir a criação ao desenho formal; e outra, que deva ensinar o manejo de programas de computador, como o Autocad etc. (J.C.O., 2002).

Apesar de ter concordado parcialmente que o computador talvez substitua a prancheta, ainda não vislumbro ferramentas adequadas para tanto. $O$ que nos preocupa é que esta corrente deteriore precocemente o ensino de desenho arquitetônico, podando nossos alunos do prazer da CRIAÇÃO, e além do que, possa prostituir a representacao do Desenho de Arquitetura, de tal sorte que não precisemos de um MANUAL DE INSTRUÇÕES, para LER um determinado projeto concebido por esta ou aquela escola de arquitetura (E.C., 2002).

> Desenho como expressão, linguagem do arquiteto:

A equipe de professores que trabalha a disciplina de desenho arquitetônico, da qual faço parte, acredita que o desenho é a forma mais eficaz de expressão do arquiteto que cria. Há necessidade de materializar as idéias, expressá-las. É necessário que os alunos não percam o hábito de desenhar, do croqui rápido ao desenho técnico. O desenvolvimento da habilidade manual - o controle da mão, do movimento, o manuseio de materiais, o peso, a agilidade, a organização, a limpeza do trabalho - leva à construção e domínio de um processo de desenho. Processo este que desenvolve, também, o maior domínio do projeto como um todo, visual e espacial. Desinibe o aluno e promove maior confiança ao apresentar suas propostas gráficas. Isto vai ao encontro da proposta desenvolvida por esta equipe de professores, onde o desenho e a composição (idéia/criatividade) são elementos complementares. Assim, esta disciplina trabalha de forma integrada com a disciplina de Estudos da Forma (Composição) (D.M.U., 2002). 
> Sobre o questionário:

Tive dificuldades em responder algumas perguntas onde a resposta era somente sim ou não - nestes momentos gostaria de responder mais ou menos (P.T., 2002).

As respostas foram parciais pelo fato de ministrar aulas de Autocad e não exatamente de desenho técnico. Como também dou aulas de projeto e desenho à mão livre, com freqüência me deparo com problemas de ordem de representação técnica nos trabalhos dos alunos. Poderia responder o questionário todo por aquilo que intuo que esteja sendo o curso de desenho técnico, mas, repito, posso estar incorrendo num erro. Com relação às questões de CAD, o curso é ministrado para alunos de primeiro ano e justamente pelo fato deles não terem ainda assimilado toda complexidade da representação técnica, as informações transmitidas quanto a escala e equalização de cotas/padrões de letras causam pouco interesse $e$, por isso penso, são facilmente esquecidas (L.R.S., 2002).

Melhorar o software (o pano de fundo desta pesquisa não tem boa visibilidade para ler) (M.C.P., 2002).

7. Se desejar saber o resultado desta pesquisa, coloque seu nome completo e e-mail:

Cinquenta e três deixaram seus nomes e e-mails; seis não deixaram.

\section{Algumas considerasões sobre o questionário}

Com este questionário buscamos, no mínimo, reunir os professores da área de desenho arquitetônico de várias escolas de arquitetura, com o fim de angariar fundamentos para refletir e discutir a melhoria do ensino desta matéria.

Resgatar sua importância requer um efetivo fortalecimento da área, constituição de novos grupos de pesquisa e outras iniciativas do tipo. Requer, também, repensar o ensino do desenho arquitetônico adaptado às novas formas de ensino, num espaço que já é de menos horas-aula que antigamente, pois novos saberes e estudos, em todas as áreas, conquistaram seus espaços no ensino da arquitetura. 
Em nossa condição de professor aconteceu que, algumas vezes, abraçando a bandeira da defesa do bom desenho arquitetônico, ensinado desde a escola, elaboramos algumas questões e até as conduzimos para, de certa forma, auxiliar a formar nossos pares, listando exemplos nas alternativas de respostas ou, sutilmente, colocando-os no próprio enunciado das questões. Nestes momentos, deixando de ser neutro ou imparcial, e também por inexperiência quanto à elaboração de um questionário e todas as implicações que daí derivam, pagamos o preço, em algumas questões, da busca não perfeitamente correta e absoluta das respostas, além de recebermos, com reconhecimento, comentários no sentido de sermos tendencioso, de alguns destes professores respondentes.

Mas, temos que considerar, por outro lado, o apoio da maioria, muitos destes parabenizando-nos pela iniciativa deste empreendimento numa área importante, mas quase esquecida. Com este espírito construtivo, muitos professores se dispuseram a participar, sendo que nem eram professores vinculados diretamente à disciplina de desenho arquitetônico:

Tentei responder ao questionário analisando os alunos que trabalham comigo nos projetos de pesquisa e o programa da disciplina, já que nunca ministrei a disciplina de Desenho Técnico e sim somente disciplinas de expressão gráfica. Para responder o item Metodologia busquei resgatar nossas conversas em reunião de Colegiado de Curso e Departamento, por isso acho que os professores que realmente ministram a disciplina apresentaram um relato mais fiel (não se identificou, 2002).

Este questionário não está muito adequado ao tipo de tarefa à qual eu me aplico atualmente. Mesmo assim procurei dar respostas aproximadas que, se parecerem úteis, poderão ser aproveitadas na pesquisa (SLF, 2002).

O questionário é claro em questões que abrem uma nova fronteira a ser explorada: nas preocupações da efetiva representação gráfica da materialidade dos objetos e de sistemas construtivos. Isto significa uma tentativa de resgate da importância do canteiro, do edifício, do perfeito entendimento do bem construir: edifício construído, viabilizado, objeto final das intenções do arquiteto.

Esperamos que, através deste questionário e de outros procedimentos desta pesquisa, este trabalho se constitua numa contribuição em busca de qualidade no ensino de desenho arquitetônico. 


\section{Análise dos Manuais de desenho arquitetônico}

1 SEGAWA, Hugo Massaki. Arquiteturas no Brasil 1900-1990 (1999). São Paulo, EDUSP, p.7879.

Realizar um levantamento, classificar e analisar os principais manuais de desenho arquitetônico constituem um dos itens de procedimento desta pesquisa. Sendo o manual - na definição do dicionário Aurélio - um livro, um compêndio que contém noções essenciais acerca de uma ciência, de uma técnica, acreditamos que os manuais de desenho arquitetônico sejam um dos recursos relevantes como apoio ao ensino de desenho nas escolas/ faculdades de arquitetura do país. Propomo-nos, pois, neste capítulo, analisar os principais manuais de desenho arquitetônico, no sentido de verificar sua validade, atualidade e contribuição efetiva para o ensino desta matéria nas escolas de arquitetura.

Inicialmente, nesta pesquisa, o levantamento dos manuais técnicos de desenho arquitetônico disponibilizados no Brasil tinha um recorte temporal estabelecido a partir de 1930, momento em que o ensino de arquitetura experimentou mudanças consideráveis. É quando o arquiteto Lucio Costa assume a direção, ainda que por pouco tempo, da ENBA - Escola Nacional de Belas Artes. Apesar de ele ter sido deposto pouco tempo depois ${ }^{1}$, alunos solidários ao novo modo de pensar a arquitetura proposta tomaram novos rumos: novos modos de projetar e representar se apresentavam no bojo das questões daqueles momentos. No entanto, entendendo a importância que os manuais e tratados tiveram ao longo da história do ensino de desenho de arquitetura, em particular a brasileira, 
interessam-nos, para a constatação do atual estado do ensino de desenho arquitetônico nas escolas de arquitetura do país, objetivo desta pesquisa, focar somente os manuais em uso hoje.

É preciso estar ciente de alguns aspectos, tais como: até que nível de profundidade o autor quis elaborar o manual; se as questões contempladas se ativeram somente aos materiais e sistemas construtivos locais; e mesmo, que tipo de arquitetura estava sendo realizada à época do lançamento desses manuais.

Não pesquisamos os manuais ou apostilas de desenho arquitetônico de Escolas Técnicas, pois se afastam um pouco da questão do ensino/recurso desta matéria em escolas de arquitetura. Os alunos de escolas técnicas gozam do privilégio de muito mais tempo de aprendizado de desenho técnico arquitetônico, além de material mais abundante e bem elaborado, porém sua formação é diferente da do arquiteto.

Através do questionário, detectamos muitas iniciativas de professores de desenho arquitetônico, que desenvolveram e desenvolvem apostilas ou manuais próprios, de uso interno. Porém, não foi possível conferir seus conteúdos, o que pretendemos realizar nos futuros desdobramentos desta pesquisa.

Nos levantamentos dos manuais existentes, constatamos - e não pudemos deixar de lado - uma tipologia de livros que não é exatamente de arquitetura, nem tampouco se constitui em autêntico manual de desenho arquitetônico. São do tipo prático: como construir sua casa, o que se precisa saber para construir sua casa etc. Advindos do exterior e encontrados nas bibliotecas de escolas mais antigas, acreditamos que, de uma forma ou de outra, foram livros de consulta dos primeiros arquitetos formados no Brasil. De maneira indireta, serviram para ilustrar como se faz um desenho técnico arquitetônico, já que os primeiros manuais nacionais são posteriores ou, se nessa época já existia algum, não foi beneficiado pela ampla divulgação.

Também há os manuais de ilustração em desenhos de arquitetura - perspectivos ou em vistas -, de exemplos de representação de vegetação, figura humana, automóveis, texturas, acabamento etc. De certa forma, foram elementos formadores de repertório, ao estudante e ao arquiteto, de diversos modos de representação gráfica em arquitetura. Novos livros deste tipo são amplamente editados até hoje. Como não se trata do desenho técnico arquitetônico propriamente dito, não os abordaremos nesta pesquisa. 
Algumas normas da ABNT relativas a desenho técnico foram consultadas. Mas, nos fixaremos, com mais detalhes, na norma NBR 6492 - Representação de Projetos de Arquitetura, que diz respeito diretamente ao desenho técnico arquitetônico.

Portanto, catalogamos os livros / manuais / apostilas - a lista se encontra no item Anexo - com a seguinte distribuição:

$>$ Normas;

$>$ Livros de Desenho Técnico;

> Livros de história do desenho técnico e do desenho de arquitetura;

> Manuais ou Livros de Desenho Arquitetônico propriamente dito;

> Livros que, indiretamente, ensinam o desenho arquitetônico;

> Livros de ilustração que, também, indiretamente, ensinam o desenho arquitetônico;

> Livros práticos de arquitetura, que indiretamente ensinam o desenho arquitetônico;

> Apostilas, iniciativas de professores de desenho arquitetônico;

$>$ Outros.

Apesar de todo este conjunto de livros/manuais que tratam do desenho de arquitetura, a análise se dará somente dos que reportam ao desenho técnico arquitetônico, recorte desta pesquisa, e que ainda são consultados pelos alunos e professores, como já citamos. Coincidem, propositadamente, com os listados na primeira questão do bloco $\mathrm{D}$ do questionário analisado no capítulo anterior.

Dentre esses livros/manuais, nos ativemos somente às principais questões do desenho técnico arquitetônico em si. Logo, os capítulos que se referem aos instrumentos e materiais de desenho, dimensões de formatos de papel, caligrafia técnica, escalas etc., apesar de importantes, não foram abordardos. Igualmente, deixamos de analisar os assuntos que dizem respeito aos sistemas de projeção ortogonal, às instalações hidráulicas e elétricas, além das perspectivas, luz e sombras etc. As questões sobre projeto - terreno, implantação, ventilação e iluminação, termos de arquitetura, compartimentos e lay-outs, legislação do código etc. - foram abordadas somente se relacionadas ao desenho em si, como representação. Estes temas são importantes, mas este trabalho tem um recorte claramente estabelecido no desenho técnico arquitetônico como representação efetiva dos materiais e dos sistemas construtivos. Interessa-nos analisar a qualidade na transmissão destes aspectos, e não dos outros, que são transmitidos aos alunos, na forma de manuais. 
ser destacados: Desenho Arquitetônico, do OBERG e outro, de mesmo nome, de Gildo MONTENEGRO. Sendo considerados os mais difundidos e conhecidos, gostaríamos de começar a análise por eles. Ainda merecem destaque os manuais/livros do CHING, indicados no questionário - assunto tratado no capítulo anterior - e que obtiveram preferência considerável.

O primeiro manual - Desenho Arquitetônico, de Lamartine Oberg -, mais antigo, vem sendo reeditado e reimpresso pela editora Ao Livro Técnico, desde 1973. A vigésima segunda edição é de 1979 (foi reimpresso em 1980, 1981, 1983, 1988, 1990, 1991 e 1995). A reimpressão de 1995 é que se encontra atualmente nas livrarias, pelo menos em seus computadores de consulta. Vale ressaltar que, ultimamente, tanto em páginas eletrônicas de livrarias como nas próprias livrarias, somente por encomenda é podemos adquiri-lo, ou seja, há um indicativo de que o livro está se escasseando.

Entramos em contato com a editora - Ao Livro Técnico - por correio eletrônico, para perguntar sobre novas edições ou reimpressões da obra e sobre o autor. Uma funcionária nos retornou dizendo que o autor é vivo ainda (nasceu em 1918), mas é seu filho, Leonardo Oberg, que está à frente no seguimento desta publicação e do curso no Centro do Rio de Janeiro - Instituto Técnico Oberg². Quanto às novas reimpressões, existe a de 2002 (considerada a trigésima quarta edição), que

\section{Desenho Arquitetônico Lamartine Oberg}

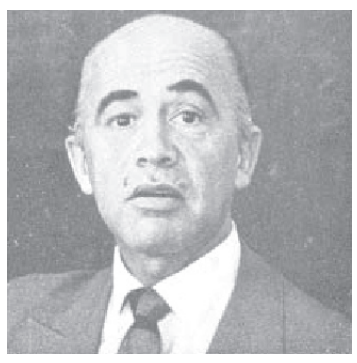

Fig.[4] 1

Lamartine Oberg, foto da década de 1960 .

${ }^{2} \mathrm{O}$ Instituto Técnico Oberg (site: www.oberg. com.br) foi fundado em 1944, completando, em 2003, 59 anos. Atualmente possui sete filiais que objetivam formar desenhistas para o mercado de trabalho, com 21 cursos livres e profissionalizantes nas áreas de Construção Civil, Técnica Industrial e Comunicação Visual (desenho livre, artístico, história em quadrinhos, publicidade e humor). Também dão cursos de CAD (Autocad).

$22^{\mathrm{a}}$ EDIÇĀO

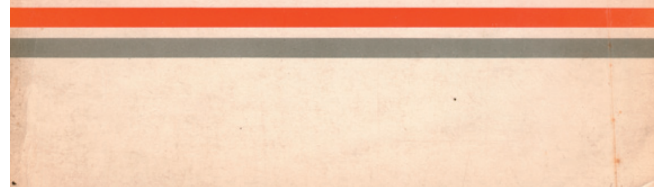

Fig.[4] 2

Capa da $22^{a}$ edição 
Fig.[4] 3

Capa da $34^{a}$ edição, 2002

${ }^{3}$ Susi Bluhm Sertã, da Editora Ao Livro Técnico, em resposta, por correio eletrônico -aolivtec@ism. com.br - 09/jun/2003.

${ }^{4}$ Idem, 13/jun/2003.

${ }^{5}$ Biblioteca da FAU/ Mackenzie, 12/04/2003.

Fig.[4] 4

Folha de rosto da edição de 1950

Fig.[4] 5

Folha de rosto da edição de 1963 mudou somente a capa; foi-nos dito que "o conteúdo do livro não foi modificado recentemente $e$, segundo os autores, não há por que mexer, pois os alunos, de diferentes fontes e idades, procuram o livro e $o$ curso justamente pelo que apresenta e o modo que ensina" 3. Escreveunos, também, que "as vendas do Desenho Arquitetônico não são volumosas para outras localidades fora do Estado do Rio de Janeiro" ${ }^{4}$. Isto nos confirma a dificuldade de adquiri-lo, pelo menos na região de São Paulo.

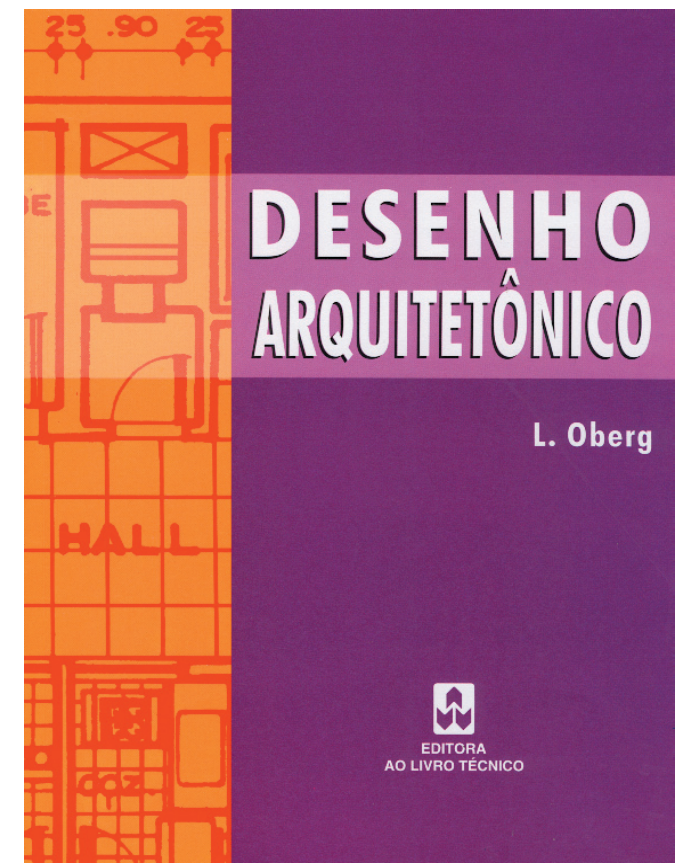

A história deste livro vem de muito antes: conseguimos encontrar uma edição de 1950 (Editora Gertum Carneiro) - talvez a primeira ou uma das primeiras edições - e outra de 1963 (editora Sedegra), cujas matrizes eram ainda elaboradas em máquina de escrever. ${ }^{5}$
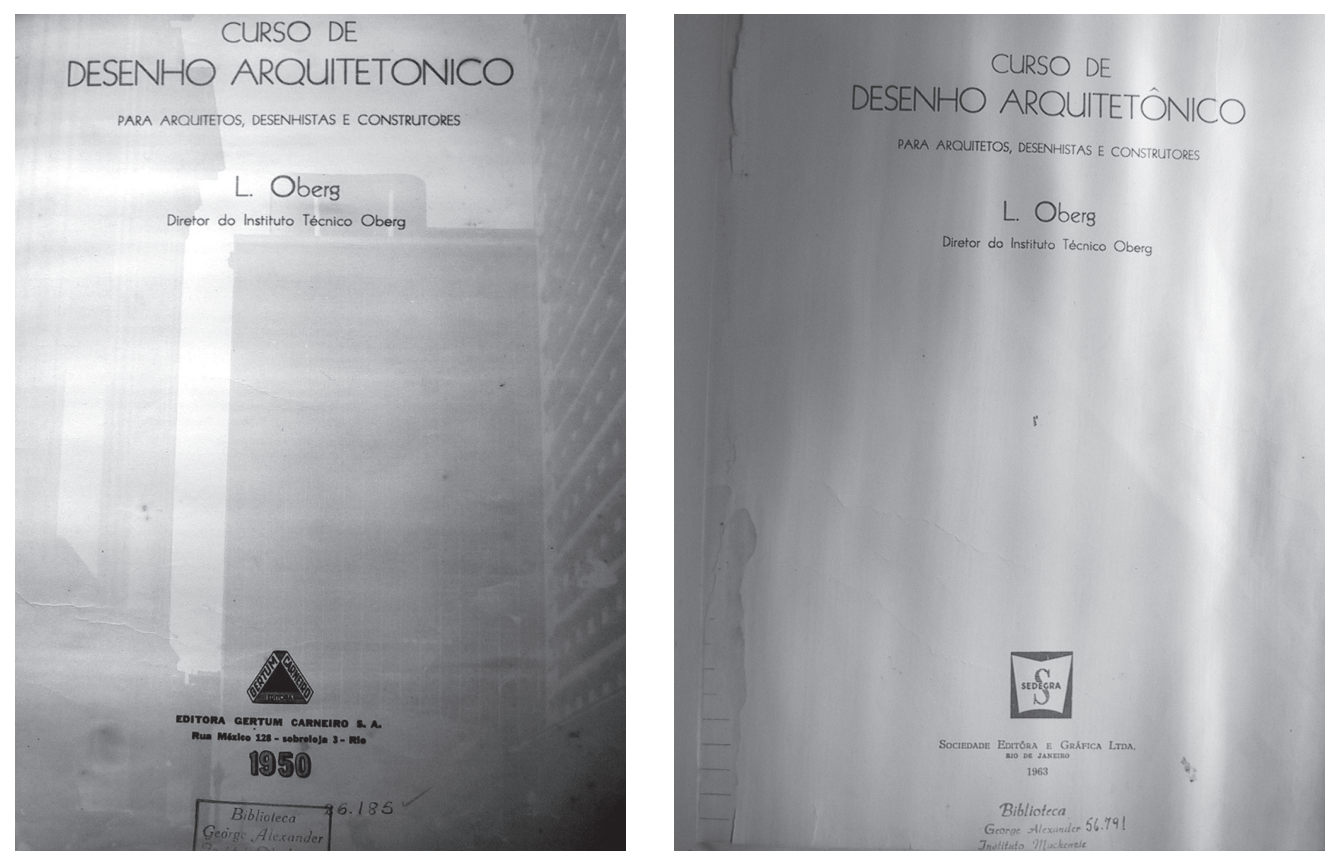

O autor, segundo escreve a editora Ao Livro Técnico nas primeiras páginas da vigésima segunda edição, é pioneiro do desenho profissional no Brasil, fundador do Instituto Técnico Oberg, no Rio de Janeiro. Foi professor de Desenho Técnico da Escola Superior de Desenho Industrial (ESDI), Rio de 
Janeiro, diretor do Instituo de Belas Artes (IBA), professor visitante da Royal College of Art de Londres, professor estagiário da Hochschule fur Gestaltung de Ulm (BAUHAUS) e na Kuntsgewerbschule de Zurique. Na vigésima edição, a editora escreve no prefácio que é o único livro em português com este título - Desenho Arquitetônico ${ }^{6}$-, mesmo em Portugal e Províncias Ultramarinas, onde é bastante procurado.

A aproximação através do contato com a editora contribuiu significativamente para a análise deste material. É preciso levar em conta que existe o curso de desenho no Instituto Oberg, no Rio de Janeiro, onde o livro certamente
${ }^{6}$ A partir de 1978, o arquiteto e professor Gildo Montenegro lança seu livro com o mesmo nome.

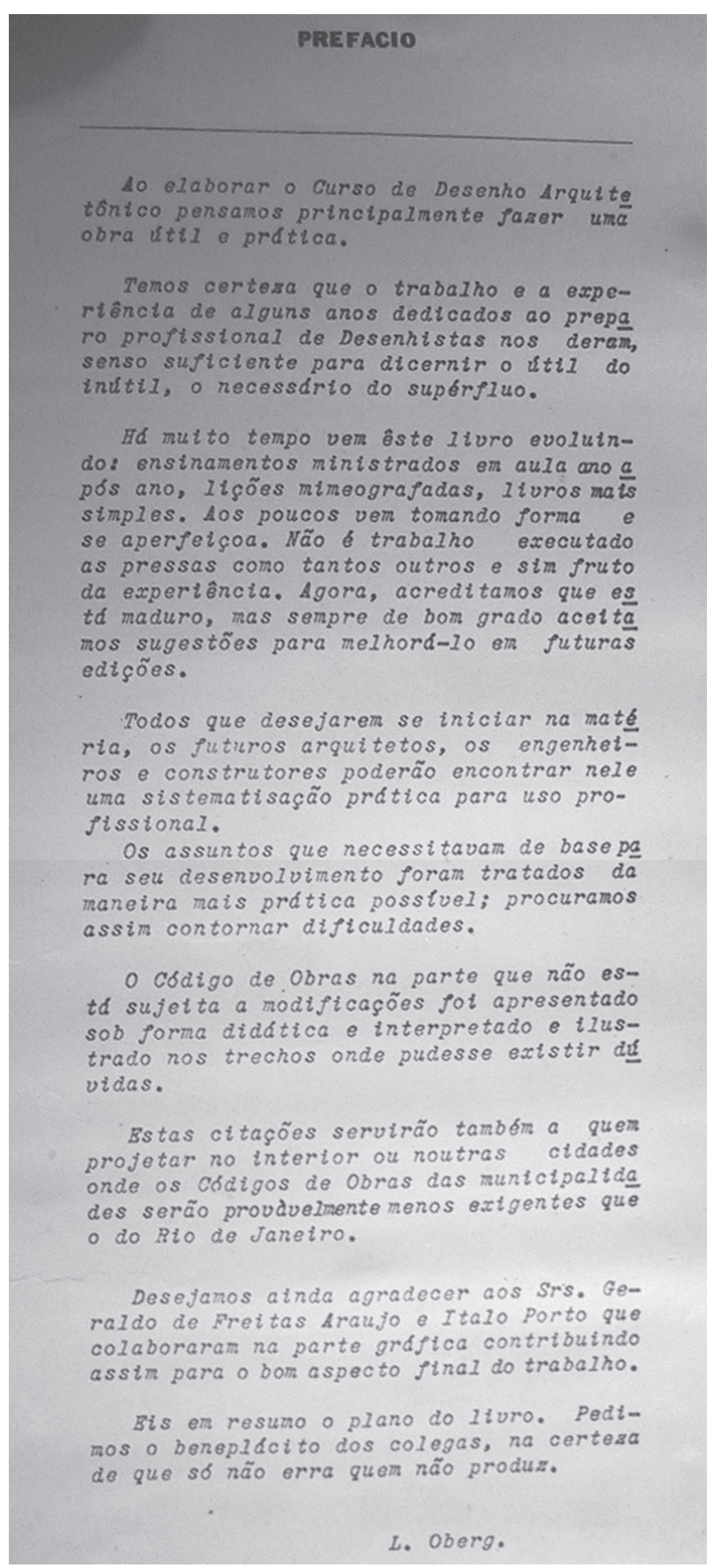

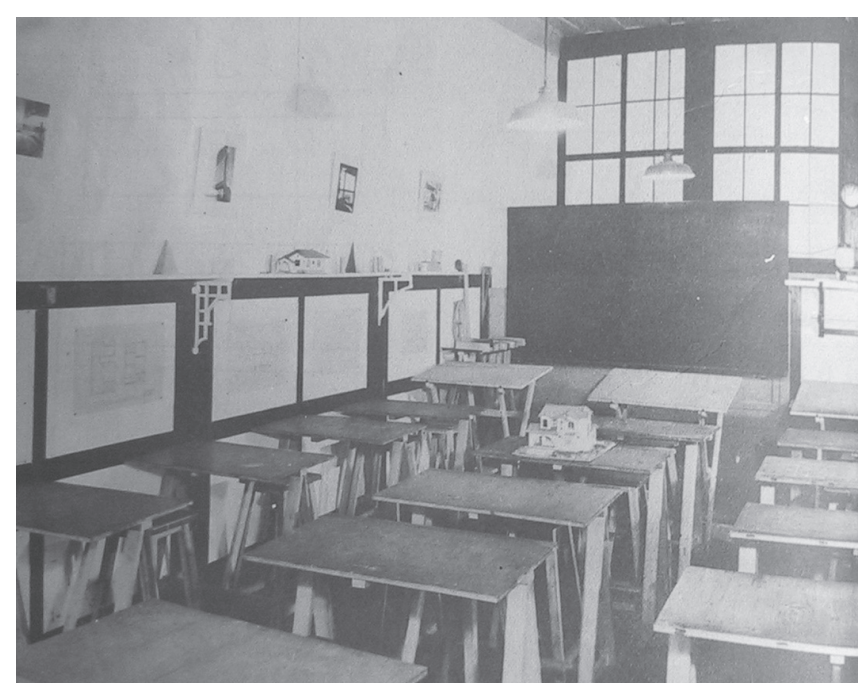

é adotado. Acreditamos que possíveis falhas ou carências do livro são complementadas ao longo do curso nesse centro de formação. Mas, dada a repercussão e difusão reconhecidas nas escolas de arquitetura de forma tão contínua, o que queremos apontar são exatamente essas falhas que, a nosso ver, devem ser revisadas no próprio livro.

O manual de Oberg é, reconhecidamente, um "best seller" no campo
Fig.[4] 6

Foto de uma sala do Instituto Técnico Oberg, presente na edição de 1950.
Fig.[4] 7

Prefácio da edição de 1950 
dos manuais de desenho arquitetônico. À época do lançamento da vigésima segunda edição, a Editora Ao Livro Técnico orgulhava-se de que poucas editoras teriam passado pela satisfação de lançar essas sucessivas edições, quando comemoravam 25 anos de existência (essa edição é de 1979 e, se havia a de 1950 - talvez a primeira - calculamos 29 anos). Em 2002, completava, então, 53 anos de reedições e reimpressões. Queremos participar desse acontecimento, reconhecendo que se trata de um caso de sucesso e que desejaríamos que continuasse sendo. Encontramos aqui uma oportunidade de contribuir com este sucesso, no sentido de, na busca da melhoria da qualidade do ensino de desenho nas escolas de arquitetura, sugerir algumas revisões e/ou complementações em alguns itens desse manual. Os outros assuntos que não analisaremos, citados no início deste capítulo, também merecem passar por uma revisão e atualização.

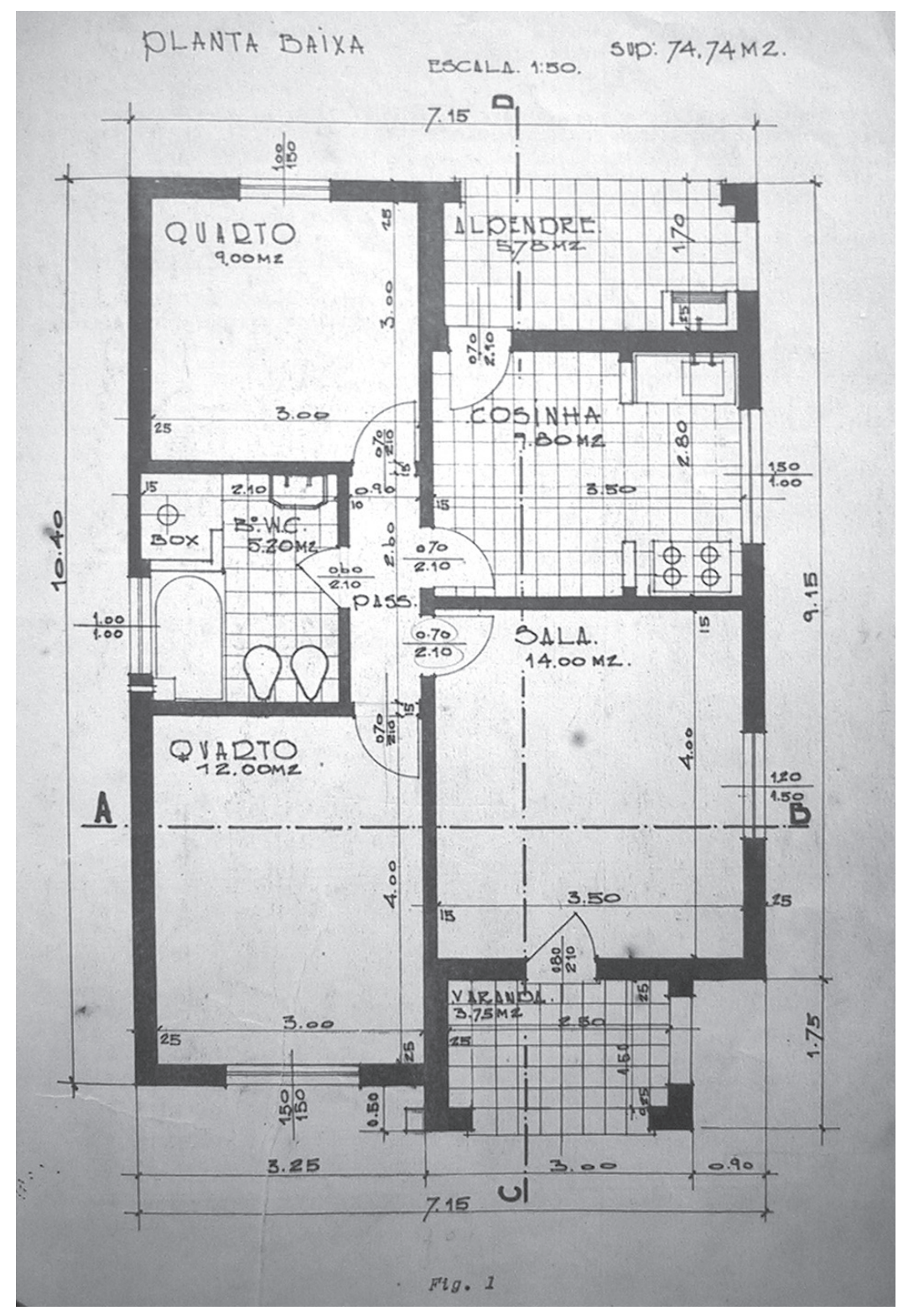



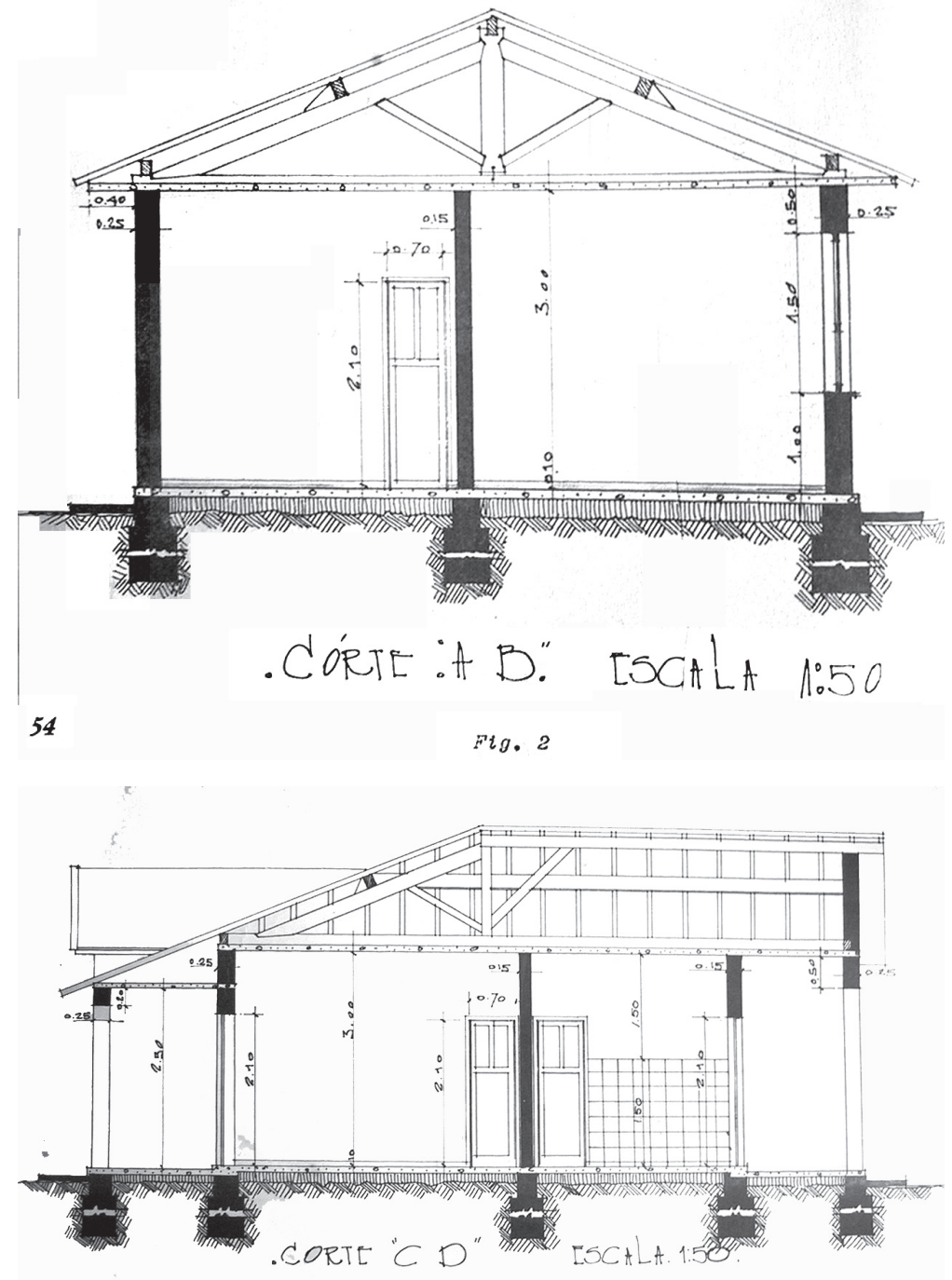

Fig. 3

O autor pretendeu sempre fazer um manual prático: desde a edição de 1950 já existiam os exercícios de residências a serem desenhados. 0 manual todo (edição de 1979) se divide em 34 capítulos. Como havíamos citado, vamos nos ater somente às principais questões de representação do desenho técnico arquitetônico em si: representação efetiva dos materiais e dos sistemas construtivos. Para maior facilidade, a análise será feita acompanhando a sequiência dos capítulos. Partimos do princípio de que o desenho deve ser aprendido e praticado pelo aluno, primeiramente à mão, com instrumentos (lapiseira, régua, esquadros etc.), conforme a maioria dos professores que responderam ao questionário, no capítulo anterior. Depois de algumas reflexões, decidimos que, apesar de não podermos, hoje, ignorar o CAD, não faremos menção a ele, salvo em algum momento oportuno, pertinente e que contribua para seu enriquecimento, assinalando outros desdobramentos desse manual. As questões aprofundadas de desenho em CAD poderão ser discutidas numa outra pesquisa.
Fig.[4] 9

Exercício para desenhar uma residência: Corte AB (edição de 1950)

Fig.[4] 10

Exercício para desenhar uma residência: Corte CD (edição de 1950) 
Começamos pelo capítulo quarto (da vigésima segunda edição) que trata dos símbolos convencionais (ver figuras 11 e 12). Com esse título, o autor quis abarcar, em apenas duas páginas (p.12-13), vários assuntos que, a nosso ver, são relevantes e mereceriam capítulos separados, ou, pelo menos, serem divididos em alguns sub-capítulos. Esse capítulo compreende linhas e suas espessuras, linhas de cotas (mas não as cotas), indicação de parede, laje e representação de textura de terra e de concreto. Também apresenta, esquematicamente, o que é peitoril, janela e verga, num desenho de corte. Na página 13, defende a idéia de que só deva existir uma única convenção para portas e janelas (dois traços no meio da parede, tanto em planta como em corte).

Na verdade, nessas duas páginas pretendeu transmitir ao leitor o vocabulário mínimo para iniciar o desenho arquitetônico. As páginas seguintes já iniciam os exercícios e, oportunamente, explicam o corte, as elevações, as esquadrias de portas e janelas, cobertura, escadas etc. No entanto, a cada um destes itens, faltam aprofundamentos. Somente as esquadrias de portas e janelas é que estão detalhadas de forma mais cuidadosa, apesar de não haver aplicabilidade clara nas plantas e cortes, em diversas escalas.

No entendimento de que o desenho arquitetônico deva mostrar a representação do material e o sistema construtivo, pelo menos a partir da escala 1:50, sentimos a necessidade de que os assuntos do capítulo quatro fossem detalhados nos capítulos seguintes, o que não aconteceu. Um desenho arquitetônico pode ser apresentado da forma como este manual ensina - desenhos mais simples, sem revestimento etc -, mas, para a completa formação de um aluno de nível técnico ou superior, a materialidade - alvenaria-osso, revestimento - e o registro claro dos componentes da estrutura devem ser contemplados e estar representados corretamente.

Assim, a representação de somente duas linhas para janelas e portas estaria perfeita somente para escala 1:100 ou em desenhos menores. Mas, na escala 1:50 (ou desenhos maiores), é possível desenhar acrescentando mais elementos: o marco ou requadro, alvenaria-osso e revestimento nas paredes etc.

Para nós, o manual apresenta uma falha no sentido de não expor, claramente, que, à medida que desenharmos numa escala maior (desenhos ampliados), aparecerão mais detalhes. Pode ser valioso mostrar, por exemplo, como se desenham uma porta e uma janela, em planta e em corte, nas escalas 1:100, 1:50 e 1:25 (ver sugestão, fig. 13). Ao invés disso, o autor dá um salto para 


\section{Símbolos convencionais}

Todos os desenhos já executados e os que vamos executar devem, em seus menores detalhes, obedecer aos sinais e convenções que, por força do hábito e da razão, foram estabelecidos para o desenho arquitetônico.

A obediência a essas convenções facilita a leitura do desenho e a sua interpretação pelos executantes da obra.

Usamos os seguintes tipos de linhas e espessuras (Fig. 4.1):
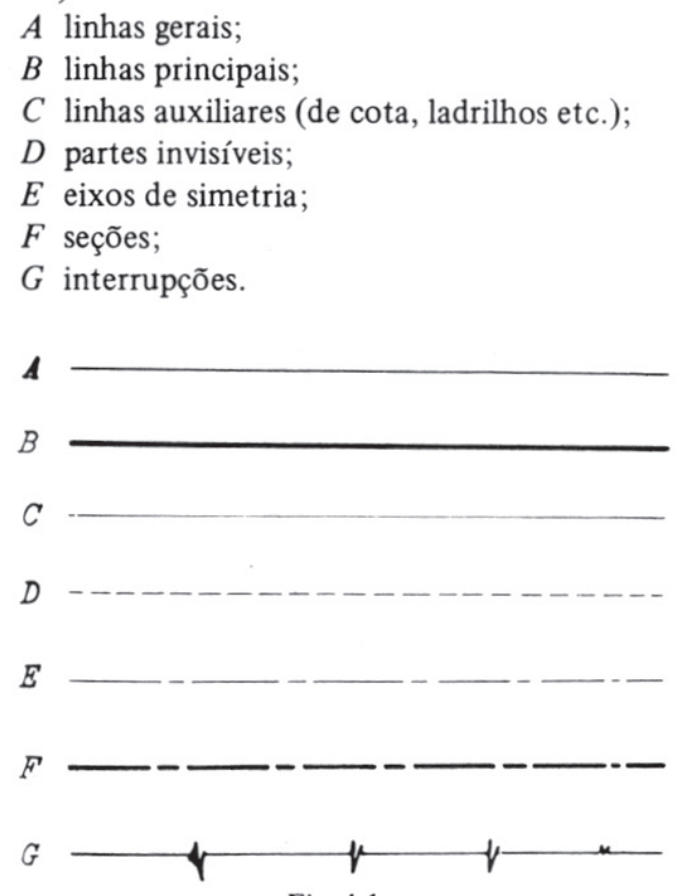

Fig. 4.1

Essas linhas deverão ser identificadas no primeiro tema prático (Cap. 5) onde, com cuidado, devemos tentar uma cópia aplicando rigorosamente as convenções estabelecidas.

As linhas de maior espessura devem ser traçadas com um lápis mole da série B, ou lapiseira com grafita B,

\section{Capítulo 4}

ou a tinta com pena 0,25 , e as linhas finas com lápis da série $\mathrm{H}$.

Para uma boa execução dos desenhos devemos observar as diferentes maneiras de representar as linhas de cota (Fig. 4.2).
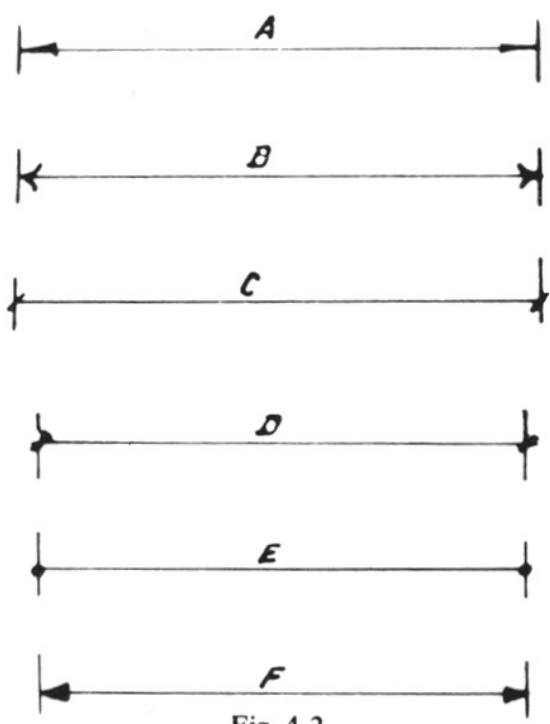

Fig. 4.2

Essas linhas, que servem para indicar a distância entre dois pontos, devem ser sempre finíssimas.

$E$ é a mais usada, $B$ e $F$ não são recomendadas porque dão ao desenho aspecto vulgar. $A$ é usada em desenho de máquinas e $C$ também pode ser usada em desenho de arquitetura.

Recomendamos que se faça o colorido das paredes pelo lado avesso dỏ papel (papéis transparentes), pois facilitará qualquer correção do lado direito.

Nota: As cópias heliográficas dos desenhos feitos em papel transparente (originais) devem ter também as paredes pintadas conforme as convenções. o funcionamento desta esquadria (ver fig. 14), mostrando até a pingadeira (capítulos 15 a 17). Faltou, porém, como havíamos citado, representá-las corretamente nas fases intermediárias $(1: 50,1: 25)$ e, sempre, a materialidade de como efetivamente é na obra: alvenaria osso, revestimento etc.
Fig.[4] 11

Símbolos convencionais:

p.12 (22a edição, de 1979). 
Concreto. As seções das lajes de piso ou de cobertura, assim como as seções de vigas, sapatas das fundações etc., de concreto, deverão ser pintadas de verde, existindo, no entanto, para o concreto, outras convenções gráficas (Fig. 4.3).

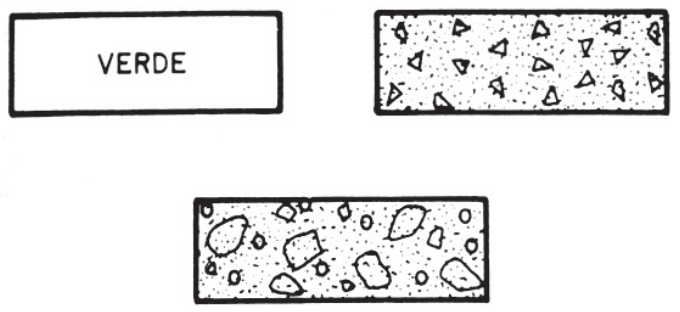

Fig. 4.3

Vamos desenhar mais algumas convenções (Fig. 4.4):

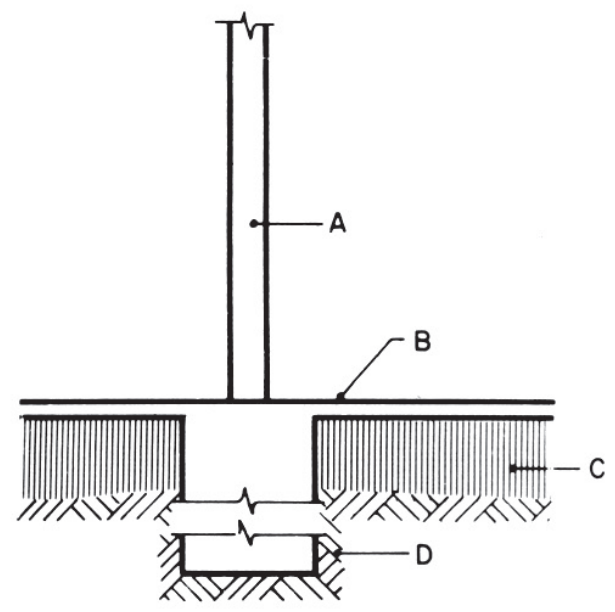

Fig. 4.4

$A$ utilizar uma das convenções de parede;

$B$ laje do piso - concreto - utilizar as convenções recomendadas;

$C$ convenções de aterro apiloado;

$D$ convenções de terra (perfil natural do terreno).

As representações convencionais aparecem sempre em qualquer espécie de desenho técnico, com o intuito de simplificar. Deixaremos entretanto, de dar um grande número de convenções de portas e janelas, dos mais diversos tipos, pois defendemos o ponto de vista de que só deve existir uma única convenção para portas e janelas.

Representaremos assim, as janelas em planta e em seção (Fig. 4.5).

Tenha a janela peitoril avançado ou não, tenha nicho, seja de guilhotina ou basculante, usaremos esta única convenção.

Fig.[4] 12

Idem, p.13

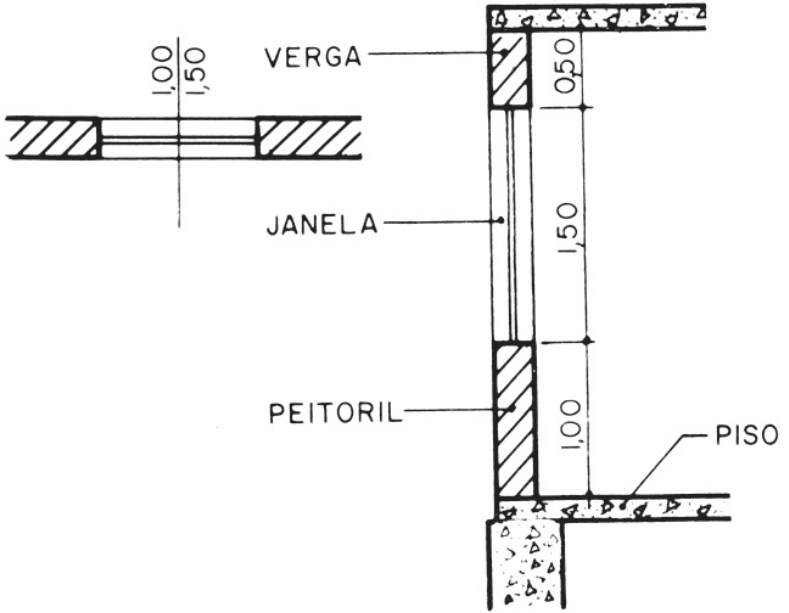

Fig. 4.5

Para diferençar as janelas segundo seu tipo, colocaremos junto a cada representação uma letra ou um número e em seguida uma nota esclarecedora. Por exemplo:

Nota: Todas as janelas $A$ serão de guilhotina dupla; ver desenho de esquadrias (detalhes). Todas as janelas $B$ serão do tipo basculante, ver desenho de esquadrias (detalhes).

As portas serão representadas sempre mostrando a abertura de suas folhas, com o intuito de facilitar o trabalho do desenhista de instalações elétricas na escolha certa do local das tomadas e interruptores e para indicar, a quem detalhar, a posição das aduelas em relação aos dois cômodos etc.

Representaremos, assim, as portas em planta e em seção.

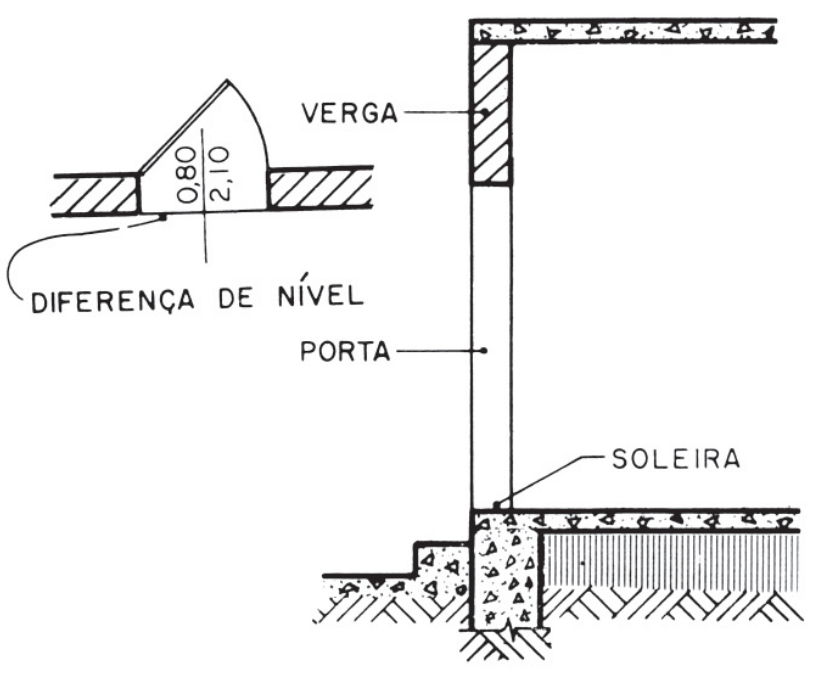

Fig. 4.6

Nota: Quando a porta servir de passagem entre dois pisos de níveis diferentes, a convenção modifica-se em parte (Fig. 4.6). 


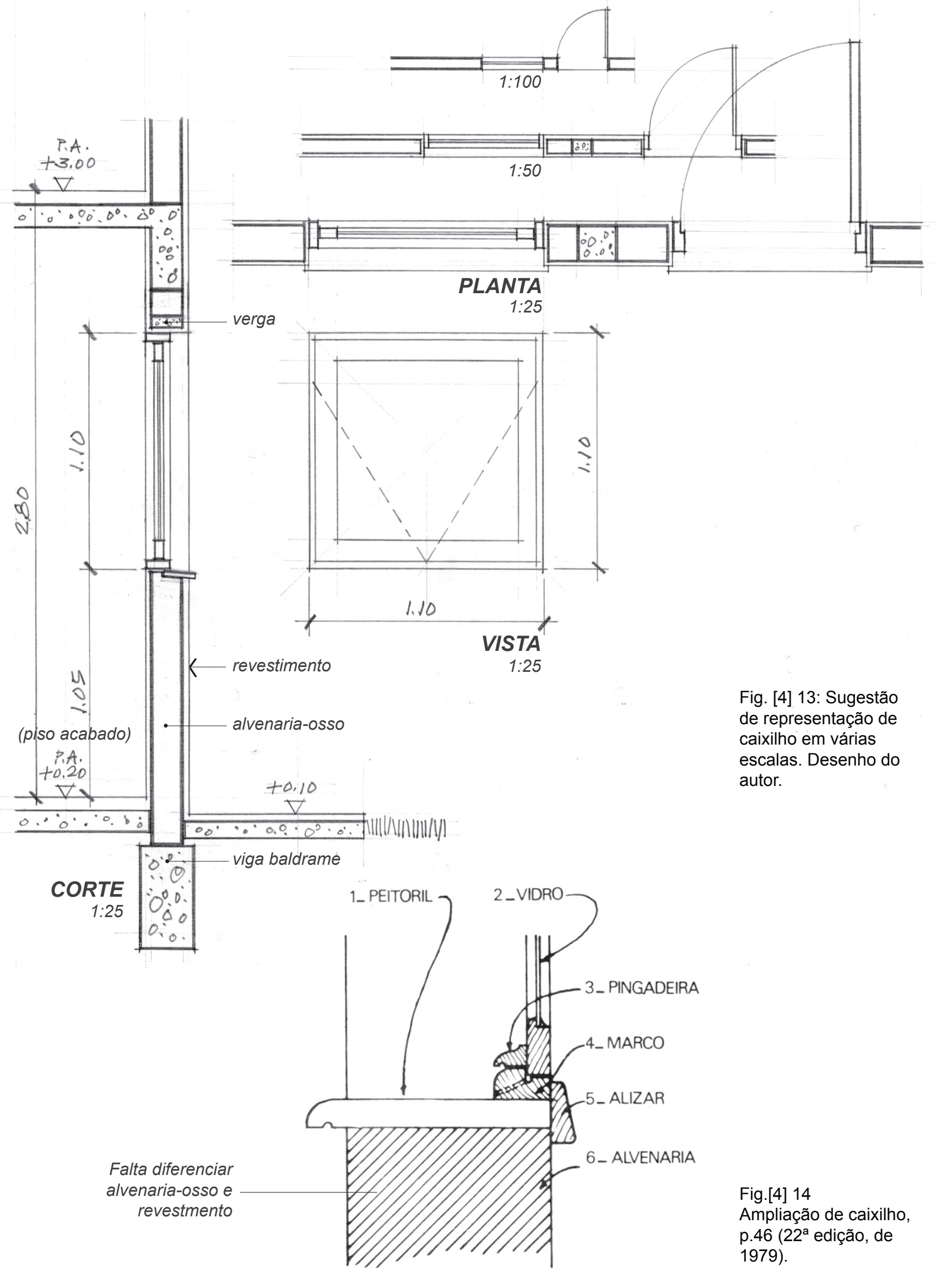


Reconhecemos que há uma gradação de acréscimo de informações ao longo dos exercícios propostos: cortes, elevação, cobertura. No entanto, no penúltimo exercício, que é um edifício residencial de cinco pavimentos (cap.26, p.89-95), no desenho de corte não comparecem as vigas, diferenciando-se das paredes e da platibanda na laje de cobertura, nem as cotas de nível etc. Além disso, proporíamos que o corte passasse no outro lance da escada, olhando para o mesmo lado, com o fim de registrar a escada inteira (um dos lances ficaria em linha tracejada), pois possibilitaria um entendimento maior e ofereceria mais informação e melhor suporte para cotá-la adequadamente. É importante para o aluno que estes procedimentos estejam colocados corretamente.

Fig.[4] 15

Corte de um edifício residencial, p.95 (22a edição, de 1979).

O ideal seria cotar de piso acabado a piso acabado

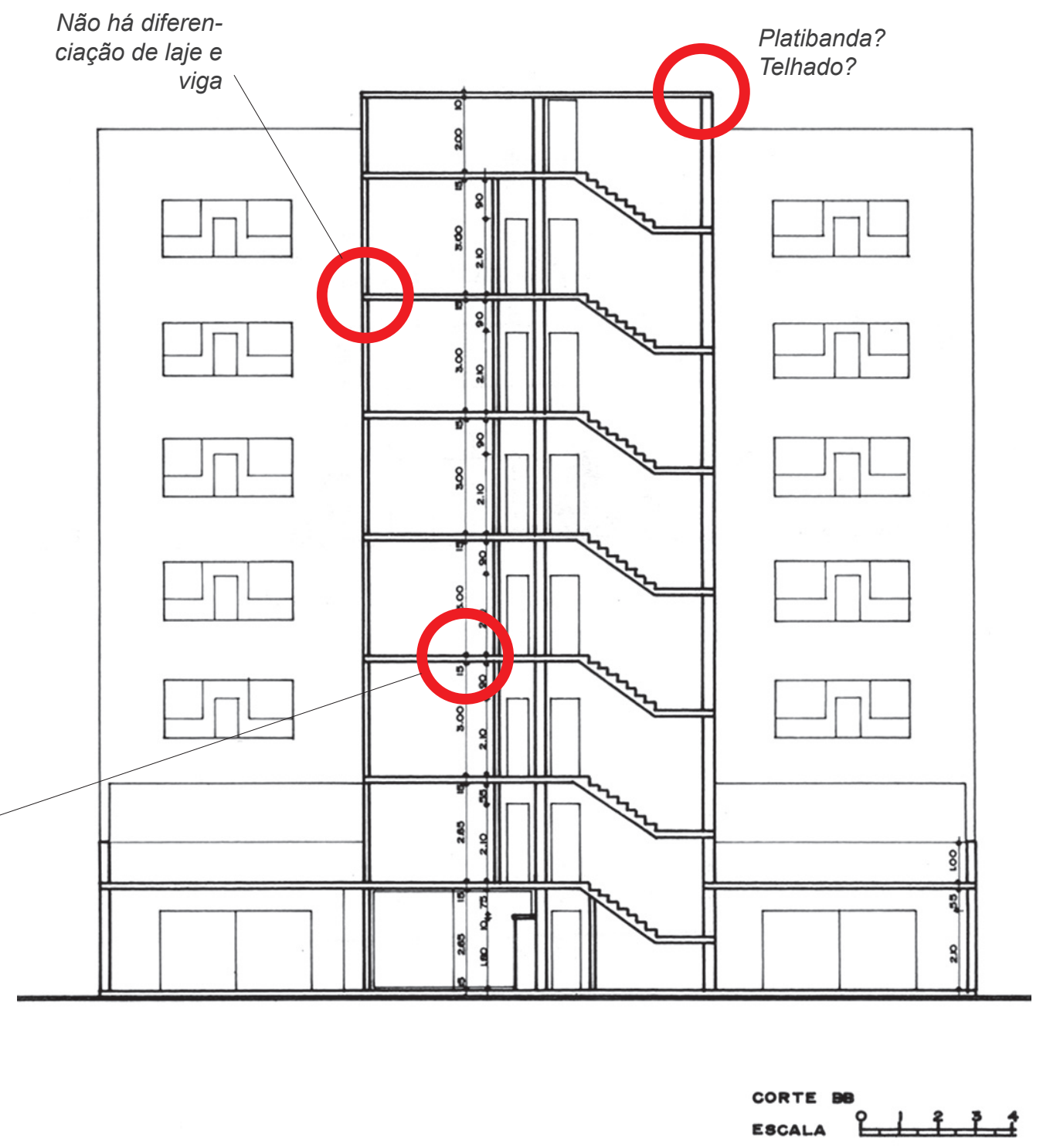

De modo idêntico, os capítulos 21 e 22, que tratam da cobertura (telhados), explicam bem todos os detalhes, tipos e terminologia, mas não há indicação (comunicação) de como aplicá-los nos desenhos dos exercícios. 
No desenho de escada do capítulo 19 , página 57 , nem sempre a caixa de escada é toda de concreto; é mais comum que seja de alvenaria. Atualmente, é proibido fazer degraus (como este manual apresenta) nos patamares entre os lances da escada, quando estar for de uso público. Achamos que o manual deveria, também, contemplar as escadas de incêndio e suas implicações, como prescrevem as normas do Corpo de Bombeiros. Nesse sentido, não houve atualização.
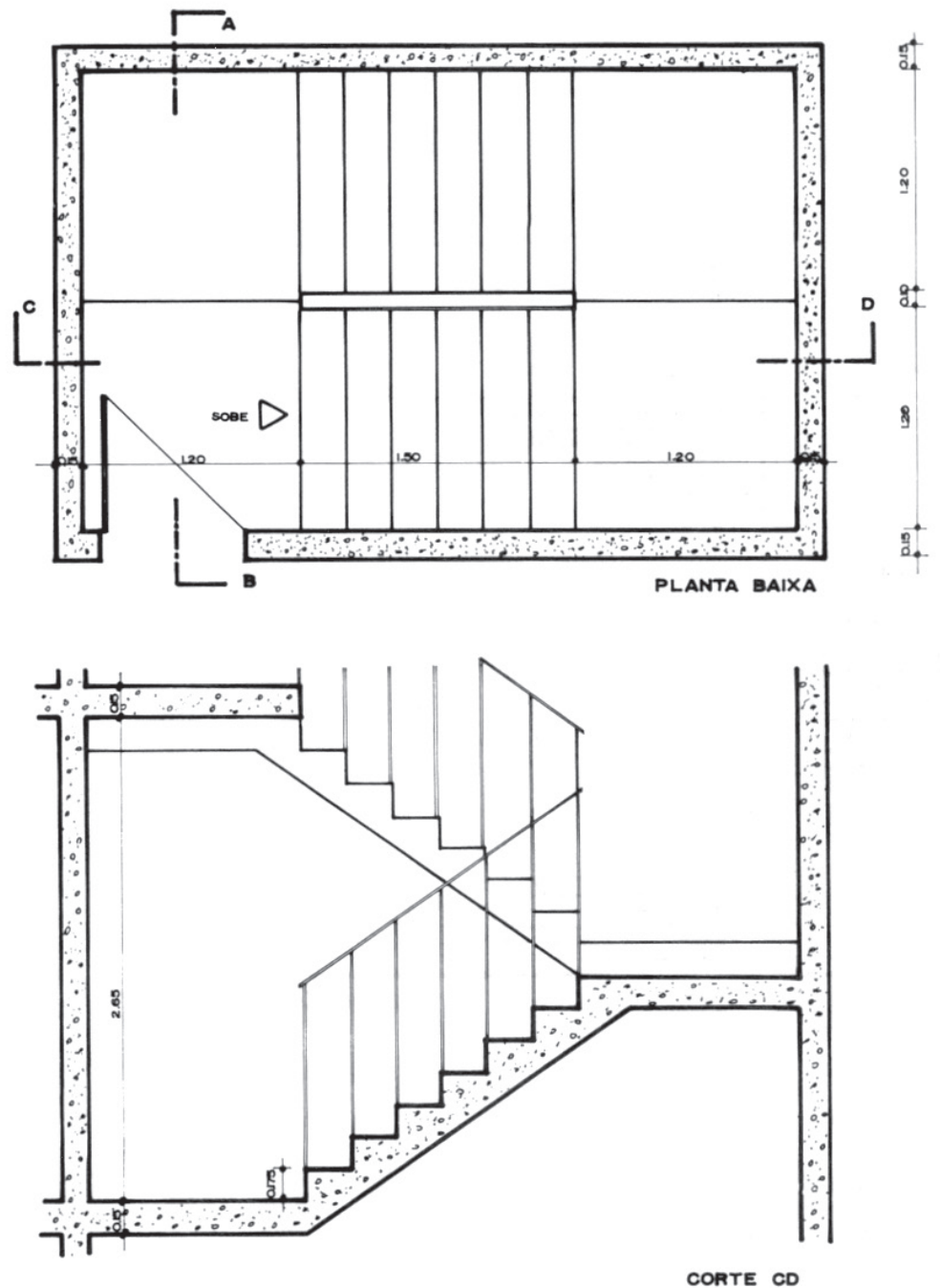

Fig.[4] 16

Escada, p.57 (22a

edição, de 1979).

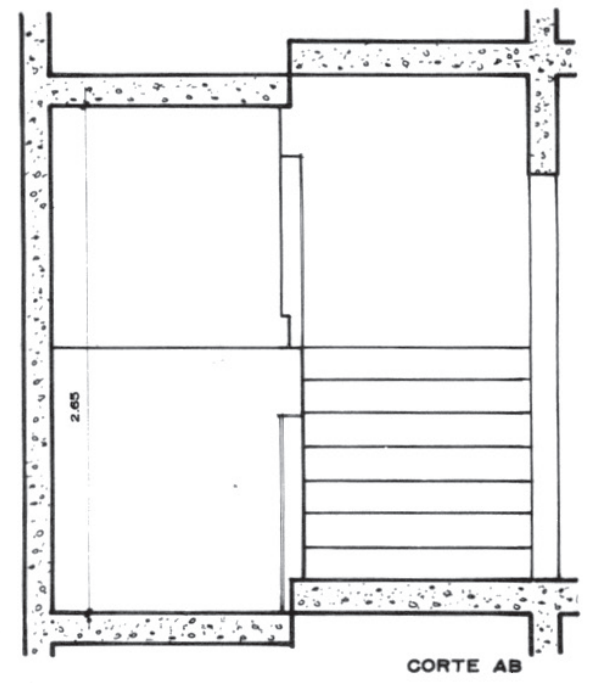

Aprendemos que, basicamente, uma construção se divide em infraestrutura, estrutura, fechamentos, aberturas e cobertura. A cada um destes temas, devemos ser informados sobre o piso (contra-piso e piso acabado) e revestimentos/acabamentos e sobre as ampliações (na escala adequada) das áreas molhadas e das esquadrias. Depois, vêm os detalhes: escadas, corrimão, guarda-corpo, portões, aberturas no teto, detalhes especiais etc. Esse manual aborda pouco ou quase nada dos dois primeiros itens: infraestrutura e estrutura. Dos outros itens, falta particularizar a correta representação a cada escala de desenho. Para completar, devemos aprender as simbologias, 
as cotas, os textos e especificações do projeto, as chamadas de detalhe com o correto endereçamento, a folha com o carimbo etc. São as informações que complementam o desenho e correspondem às ações da boa comunicação "interna" (entre os desenhos) e "externa" (entre os profissionais). Com relação aos últimos itens, o manual é falho, e quando os apresenta, é de modo muito superficial.

Um dos primeiros exercícios com os instrumentos (lapiseira, régua T ou paralela e esquadros) consiste no treino de traço, as linhas: fina e leve, fina e firme, forte, grossa, traço e ponto, tracejada etc. Talvez, à época das reedições desse manual, não tenha sido possível a impressão em tons de cinza, o que seria ideal e mostraria, com realismo, o mais elementar do desenho técnico - as linhas e suas possibilidades de expressividade, leveza e força, densidade, texturas, hachuras etc. No manual, as linhas apresentam-se já em nanquim, omitindo-se a etapa do treino de traço, a lápis ou lapiseira.

Por fim, as explicações sobre as cotas não comparecem em momento algum, senão em meia página do capítulo quatro, especificando, porém, somente os tipos de setas ou outro tipo de notação nas extremidades das linhas de cotas. Sentimos falta de uma cuidadosa apresentação dos procedimentos da cotagem: seus elementos básicos - linhas de cota, linhas de chamada etc -, bem como suas posições, critérios de como cotar corretamente, cotas funcionais etc., ilustrados com exemplos didáticos. Nos exercícios, as cotas aparecem nas plantas e cortes, mas sem explicação alguma, além de não seguirem rigorosamente as regras estabelecidas em desenho técnico e normatizadas pela ABNT. Tratando-se de um manual de desenho arquitetônico, as cotas deveriam se apresentar segundo as normas, na melhor forma possível.

As linhas de cotas devem se afastar de 7 a $10 \mathrm{~mm}$ do desenho. Não deve haver interrupção da linha auxiliar entre as cotas parciais e totais. A linha auxiliar deve se estender até a linha de contorno do desenho, porém, sem tocá-la (ABNT NBR 6942, item A-9 e NBR 10126, item

4.2)

Fig.[4] 17 As cotas de uma planta, p.25 (22 ${ }^{\mathrm{a}}$ edição, de 1979).

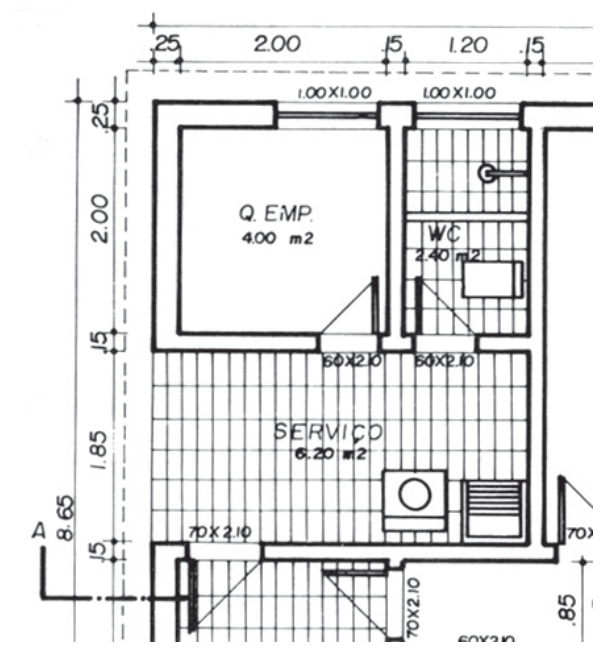

Consideramos, portanto, que somente é possível aprender desenho arquitetônico com esse manual se houver a presença de professor, arquiteto ou outro que complemente com explicações o seu conteúdo. Parece-nos que o intuito desse manual, como alguns outros, é de apresentar somente o desenho pelo desenho. É claro que não deixa de ser o desenho arquitetônico, onde estão registrados os espaços, sua distribuição, 
suas relações com o entorno imediato; nos cortes, as medidas de altura, relações volumétricas etc., porém o nosso apelo, foco principal desta pesquisa, é que se apresentem, também, os elementos construtivos e seus sistemas, além da clara exposição das diferenciações dos materiais. Também os aspectos relacionados à comunicação devem ser enfatizados. Se estamos formando um profissional desenhista ou arquiteto, através do desenho arquitetônico, estas questões devem se fazer presentes, na busca da melhoria do ensino e prática deste desenho técnico. Caso contrário, estaria no limite da superficialidade, seria um desenho distante do que realmente é o edifício a ser construído. Todos estes quesitos devem ser cuidadosamente revisados e complementados para atualizar esse manual, que ainda pode voltar a ser muito consultado pelos alunos, professores, desenhistas e arquitetos.

\section{Desenho Arquitetônico Gildo Montenegro}

O manual de Gildo Montenegro (nascido em 1931, arquiteto e, mais tarde, professor universitário) também leva o mesmo nome: Desenho Arquitetônico. É uma publicação mais recente, iniciando-se em 1978. Nasceu de uma edição particular do autor, na forma de apostila para atender às necessidades dos alunos. Logo depois, pela carência desse tipo de material e atendendo a sugestões, tornou-se um livro com a intenção de informar e orientar o "futuro desenhista”, na formação do arquiteto.
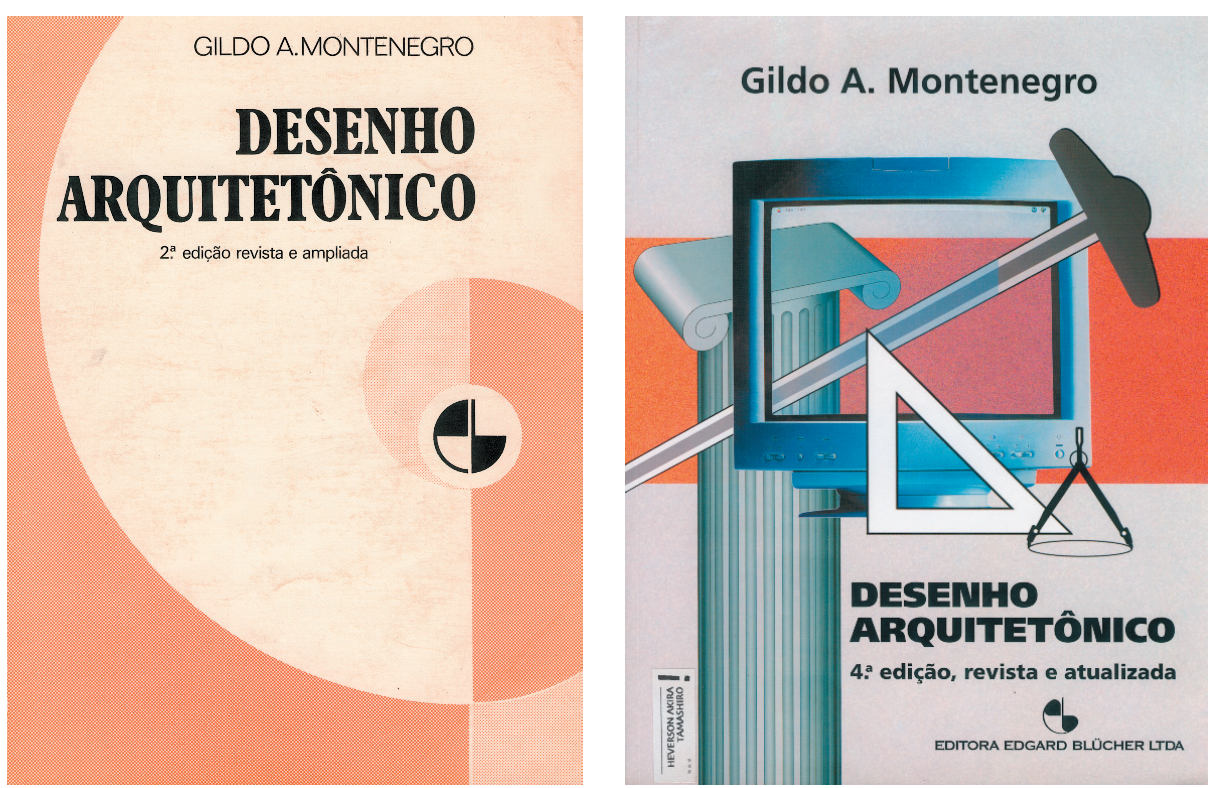

Fig.[4] 19

Capa da $2^{\mathrm{a}}$ edição, de 1985 (1 reimpressão, 1987).

Fig.[4] 20

Capa da $4^{a}$ edição, de 2001 (primeira reimpressão, 2002). 
Com estilo informal, que parece ser próprio do temperamento do autor, o manual é ilustrado com desenhos animados, talvez para tentar passar o vasto conteúdo de forma mais amena, mais agradável, com o fim de conquistar os leitores. No geral, trata-se de um manual mais completo e consistente que o de Oberg, sob alguns aspectos. Em muitos momentos, os desenhos são complementados com textos mais extensos, de que um leitor atento muito se beneficiará.

Quando da análise deste manual, tínhamos em mão a edição de 1985, de onde selecionamos algumas imagens e fizemos alguns comentários. Nos momentos finais deste trabalho, conseguimos a de 2002, revista e atualizada. Quando oportuno, elaboramos novos comentários e colocamos neste trabalho as novas imagens desta última edição .

O livro explica bem sobre grafismo, a técnica do uso do lápis, mas peca, também, em não registrar essas preocupações em modo de tons de cinza, o que denotaria mais realismo (capítulo 3, p.12) nas primeiras etapas do desenho. Isto vai se repetir, com prejuízo ao aprendiz, na proposição de um exercício de desenho completo de uma residência (capítulo 12, p.67 e 68), que seria uma ótima oportunidade de apresentar ao aluno leitor, como ficam os primeiros traços e os traços de acabamento no tom de grafite mesmo (tons de cinza), e não a nanquim. A idéia da exposição dos primeiros traços, linhas auxiliares que estruturam o desenho da planta, que vão ganhando novas informações etc. é a melhor forma de transmitir o correto modo de elaborar um desenho técnico. Isto não acontece claramente neste livro e, no de Oberg, é ignorado.

Fig.[4] 21

Primeiros traços de desenho de uma planta, p.67 (edição de 1985)

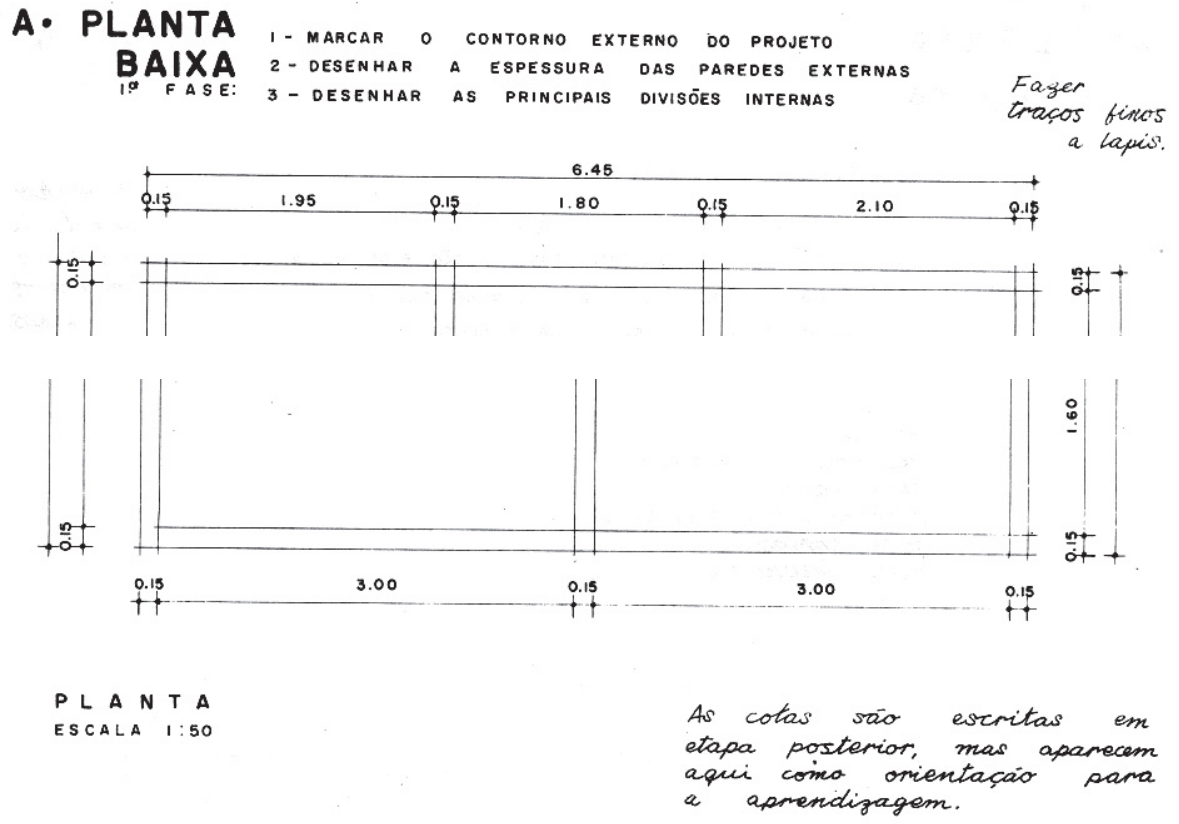


$\mathrm{Na}$ edição de 2002, felizmente, esta preocupação é corrigida, registrando esses primeiros traços (são as linhas auxiliares) a grafite:

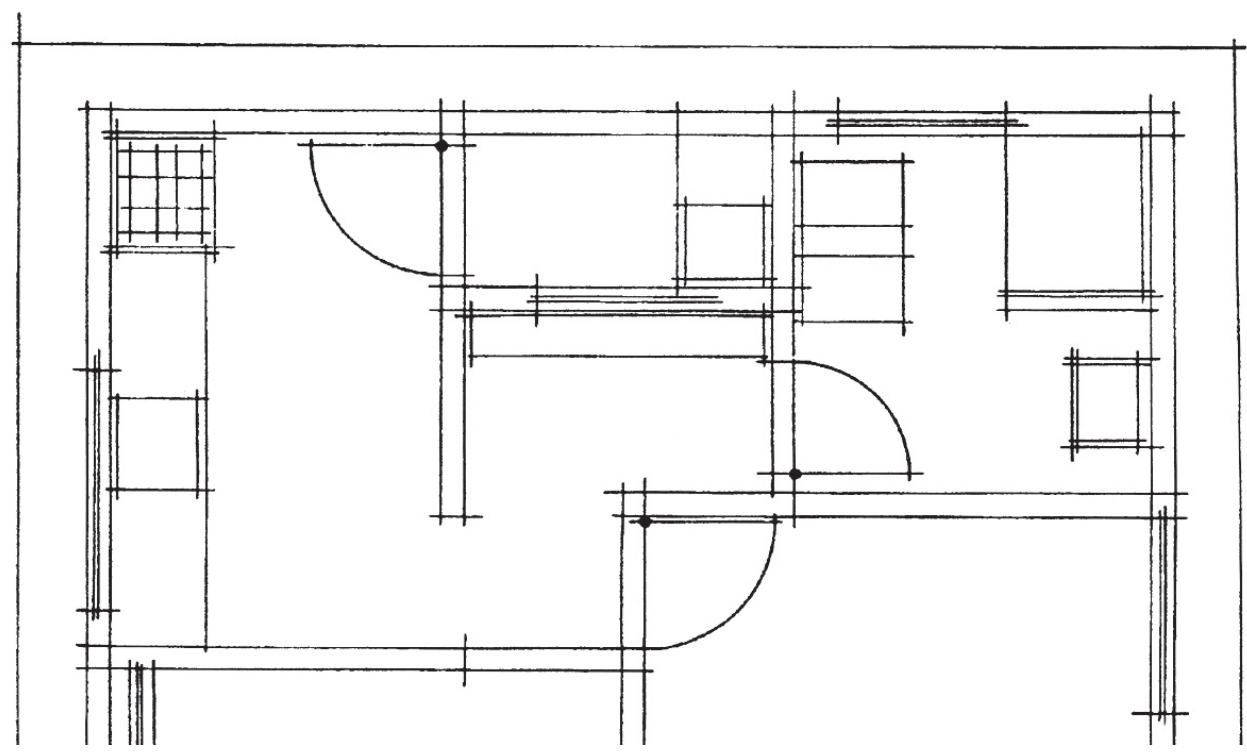

Gildo Montenegro acrescenta, também, o tratamento a ser dado numa parede em planta, com o uso de hidrocor ou lápis colorido. Por motivos técnicos de gráfica, substitui por uma retícula. A nosso ver, parece ser mais uma ilustração
Fig.[4] 22

Primeiros traços (a lápis) de desenho de uma planta, p.78 (edição de 2002)
Fig.[4] 23

As alvenarias de uma planta, p.64 (edição de 2002)
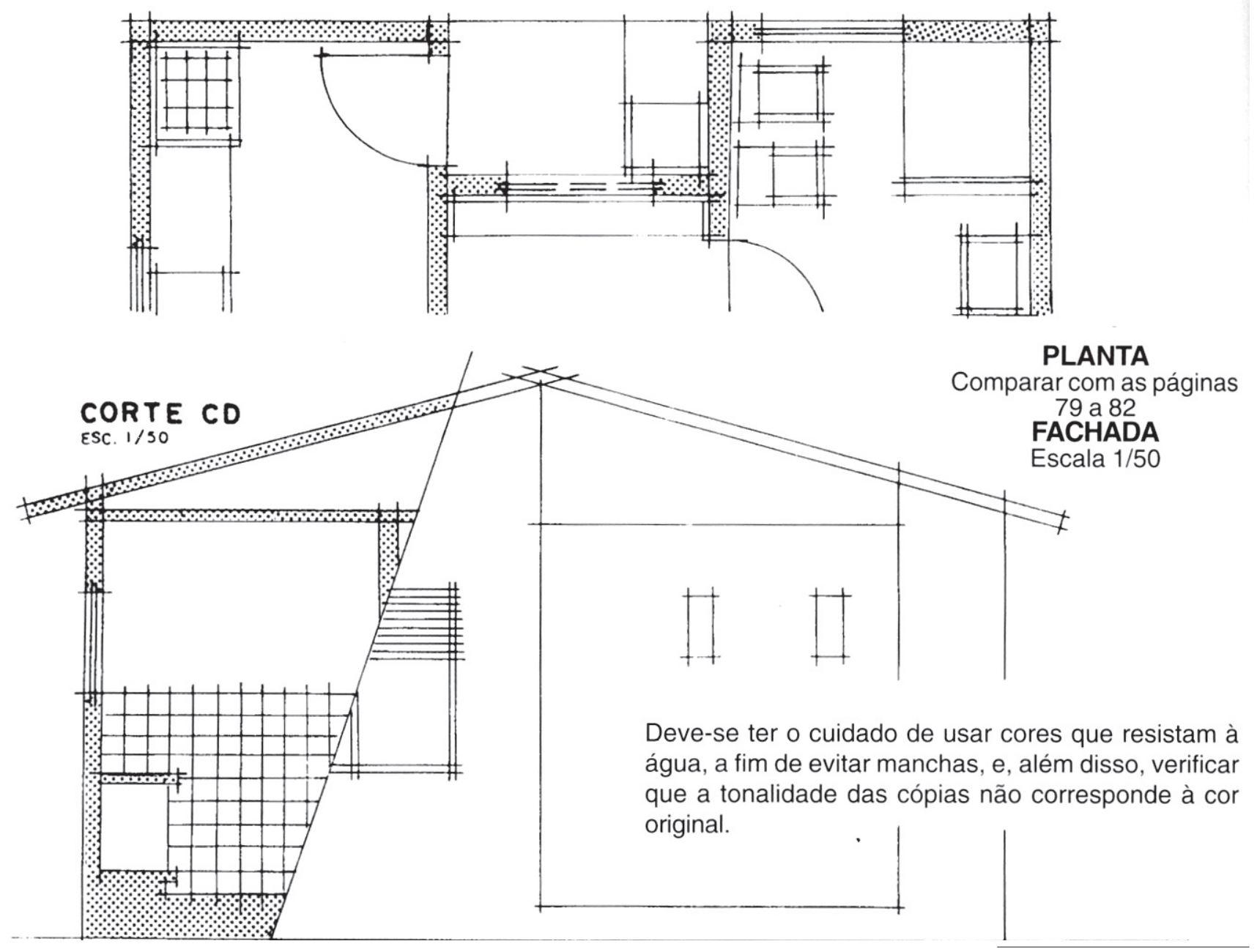
do que a intenção de um desenho técnico arquitetônico: a materialidade dos elementos da construção não são distingüíveis (pilares e alvenaria osso na planta; e lajes, vigas, alvenaria, piso no desenho em corte), salvo em um pequeno desenho de planta (figura 24).

Fig.[4] 24

As alvenaria de uma planta, p.64 (edição de 2002)
Fig.[4] 25

As cotas, p.37 (edição

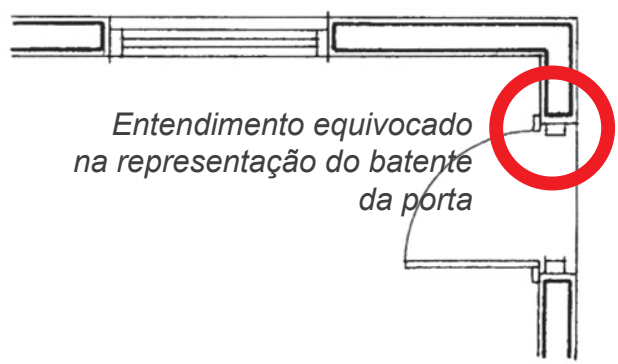

Outro problema é que as explicações de cotas se apresentam muito mais por textos que por desenhos, o que deixa a desejar. É uma espécie de exposição do assunto à base de "recados", interessantes apenas à primeira vista. Mas, cada um destes "recados" merecem muitas informações, são importantes, e poderiam ser ilustrados com exemplos em desenhos de arquitetura. Ainda sobre as cotas, os exercícios mostram-nas melhor posicionadas que o manual de Oberg, mas ainda em desacordo com as normas técnicas de cotagem.

\section{COTAS SĀO OS NÚMEROS QUE CORRESPONDEM 'AS MEDIDAS.}
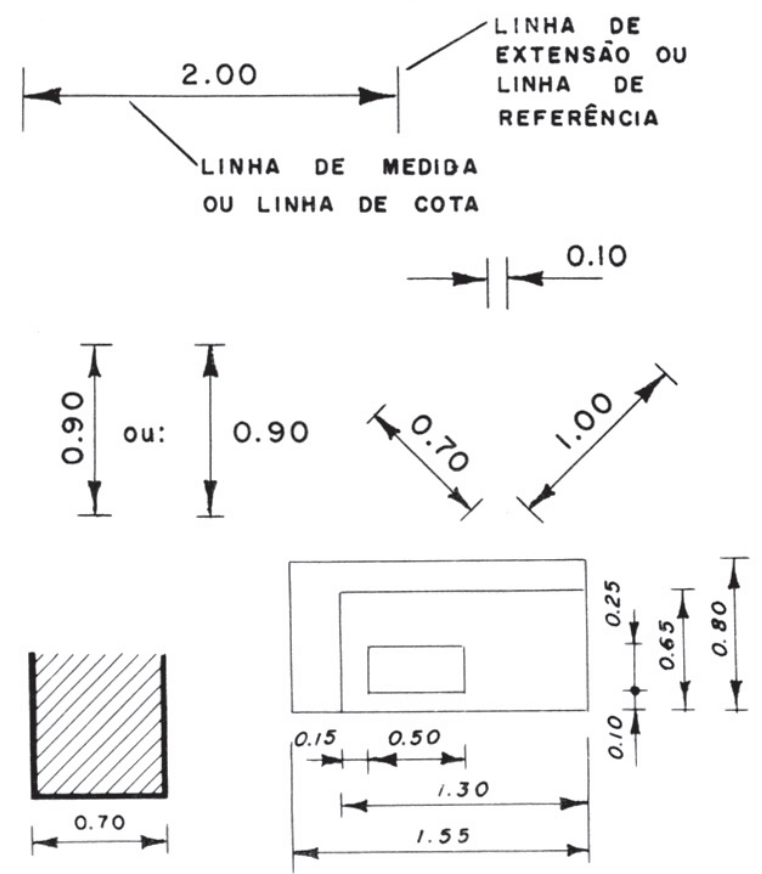

AS SETAS PODEM SER SUBSTITUIDAS POR:
A UNIDADE USADA É O METRO

ou O Milímetro (menos utilizado).

Os desenhos de Arquitetura, como os demais desenhos técnicos, devem trazer corretamente indicadas todas as suas medidas. Qualquer medida errada ou mal indicada dará sempre prejuizos e aborrecimentos.

No desenho ao lado aparecem as indicações corretas de cotas em diversos exemplos.

As cotas devem ser escritas na posição horizontal, de modo que sejam lidas com o desenho em posição normal, colocando-se o leitor no lado direito da prancha. Qualquer que seja a escala do desenho, as cotas representam a verdadeira grandeza das dimensões.

Evite o cruzamento de linhas de cota. É importante! Os algarismos das cotas são colocadas ACIMA da linha de cota, quando a linha é contínua; se a linha é interrompida a cota ocupa o espaço desta interrupção.
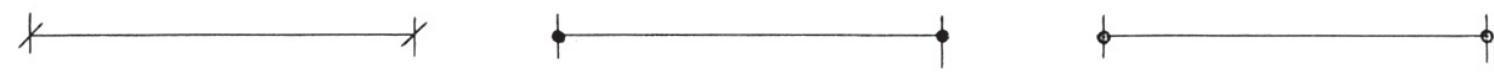
38 Desenho Arquitetônico

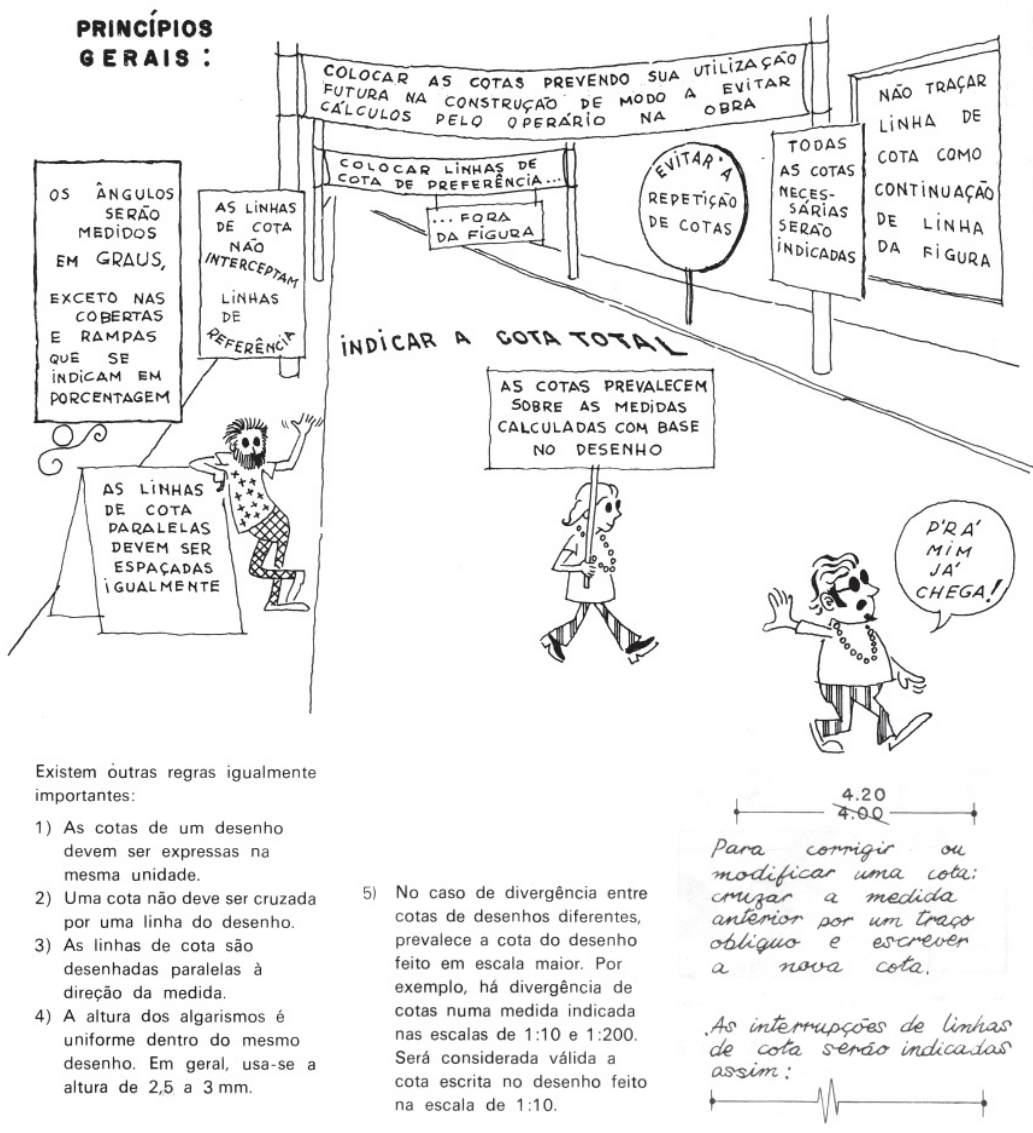

Fig.[4] 26

As cotas, p.38 (edição de 1985)
Fig.[4] 27

As cotas, p.39 (edição de 1985)
Igual que o

manual de

Oberg (ver p.135 deste trabalho), os procedimentos de cotagem devem seguir as normas da ABNT (NBR 6942, item A-9 e NBR 10126, item 4.2)

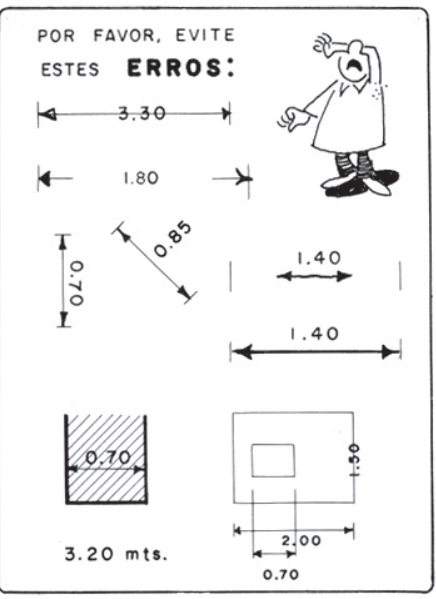

Para testar sua capacidade de

Para testar sua capacidade
observação, o leitor deverá observação, o leitor deverá na figura desta página.

Respostas (da direita para a esquerda e de cima para baixo):

1) Medida 3,30 cruzada nor linha de cota. As extremidades das setas são diferentes. 2) Os algarismos estão muito afastados da linha de cota de 1,80 . As setas estão diferentes. 3) A cota 0,70 deveria ser escrita de baixo para cima (sentido inverso) de modo a ser lida pelo lado direito da página. 4) A cota 0,85 deveria ser escrita paralelamente à linha de cota. 5) A linha de cota correspondente a 1,40 es. tá desenhada com traco grosso; as setas deveriam ter suas extremidades nas linhas de referencia $A$ segunda cota de 1.40 deveria ter sua linha de cota em traço fino. 7) A cota 0,70 deveria ser escrita fora da figura. Sendo necessário, escrever uma cota dentro de uma área hachurada (com traços paralelos) deve-se interromper o hachurado ao redor de letras e algarismos. 8) A abreviatura de metro é $\mathrm{m}$, letra minúscula (sem ponto de abreviatura, sem $t$ e sem $s$ !). Ė a lei metrológica brasileira. 9) No último desenho, a cota 1,50 está cruzada por linha da figura. As linhas de referência da cota 0,70 cruzam a linha de cota de 2,00 .

As medidas 2,00 e 0,70 estão colocadas abaixo da linha de cota, quando deveriam estar acima desta linha.

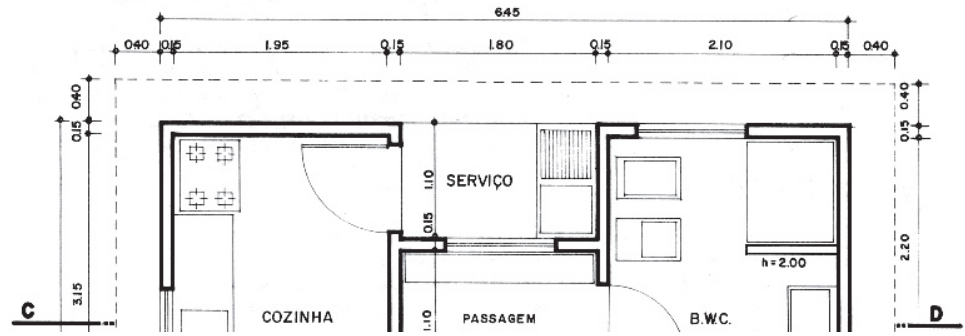

Fig.[4] 28

As cotas nos desenhos, p.69 (edição de 1985) 
Fig.[4] 29

Desenho de corte de uma residência, p.71

(edição de 1985)
O manual trata das especificações (p.77) e de detalhes construtivos (cap.14, p.83-93): fundação, alvenarias, estruturas, cobertura e revestimentos. No entanto, não as aplica nos exercícios propostos: projeto de uma residência de dois pavimentos (cap.19, p.125-130) e projeto de um edifício de apartamentos com seis pavimentos (cap.20, p.131-138). Os desenhos de cortes ignoram a infra-estrutura e todo o desenho não diferencia o que são lajes, vigas e paredes.

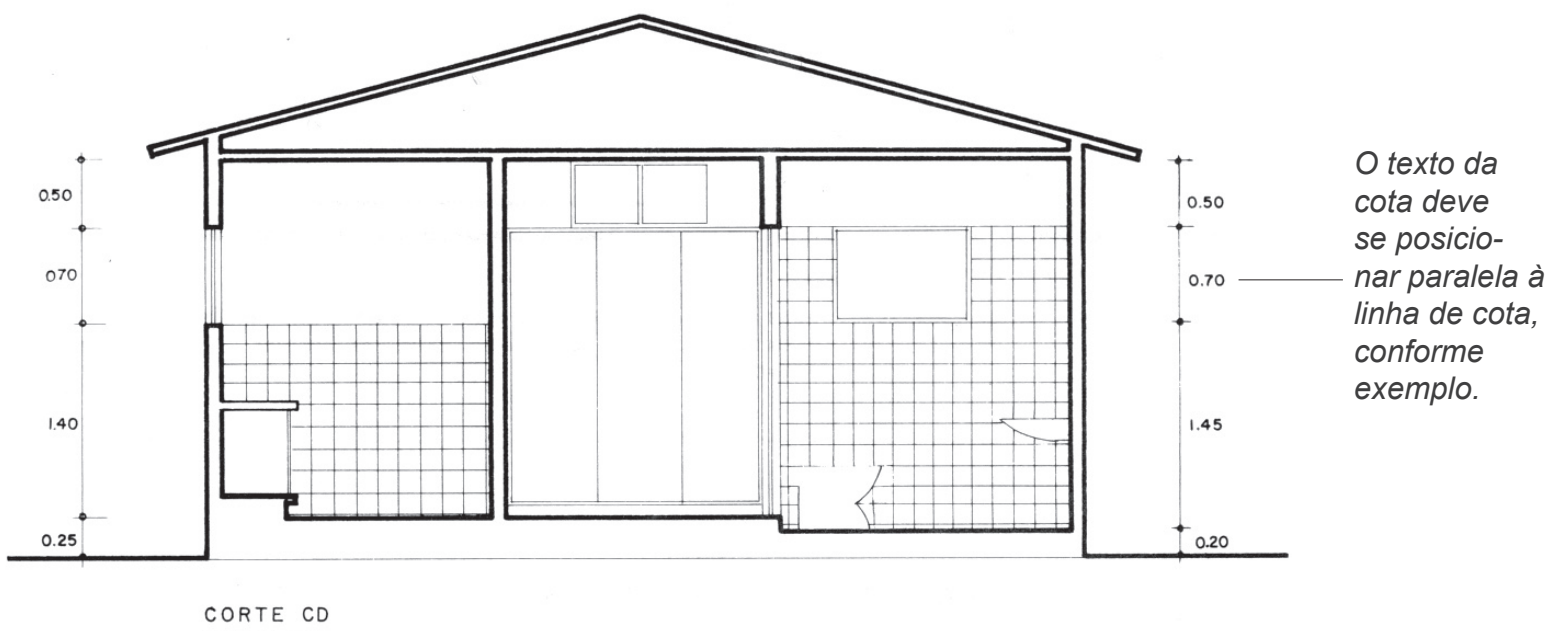

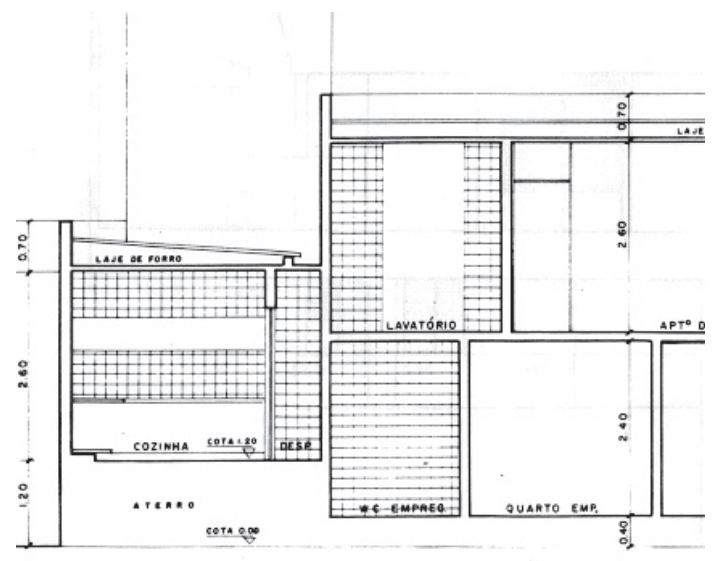

Fig.[4] 30

Desenho de corte de uma residência (cap. 19), p.129 (edição de 1985)

Fig.[4] 31

Desenho de corte de um edifício, p.135 (edição de 1985)

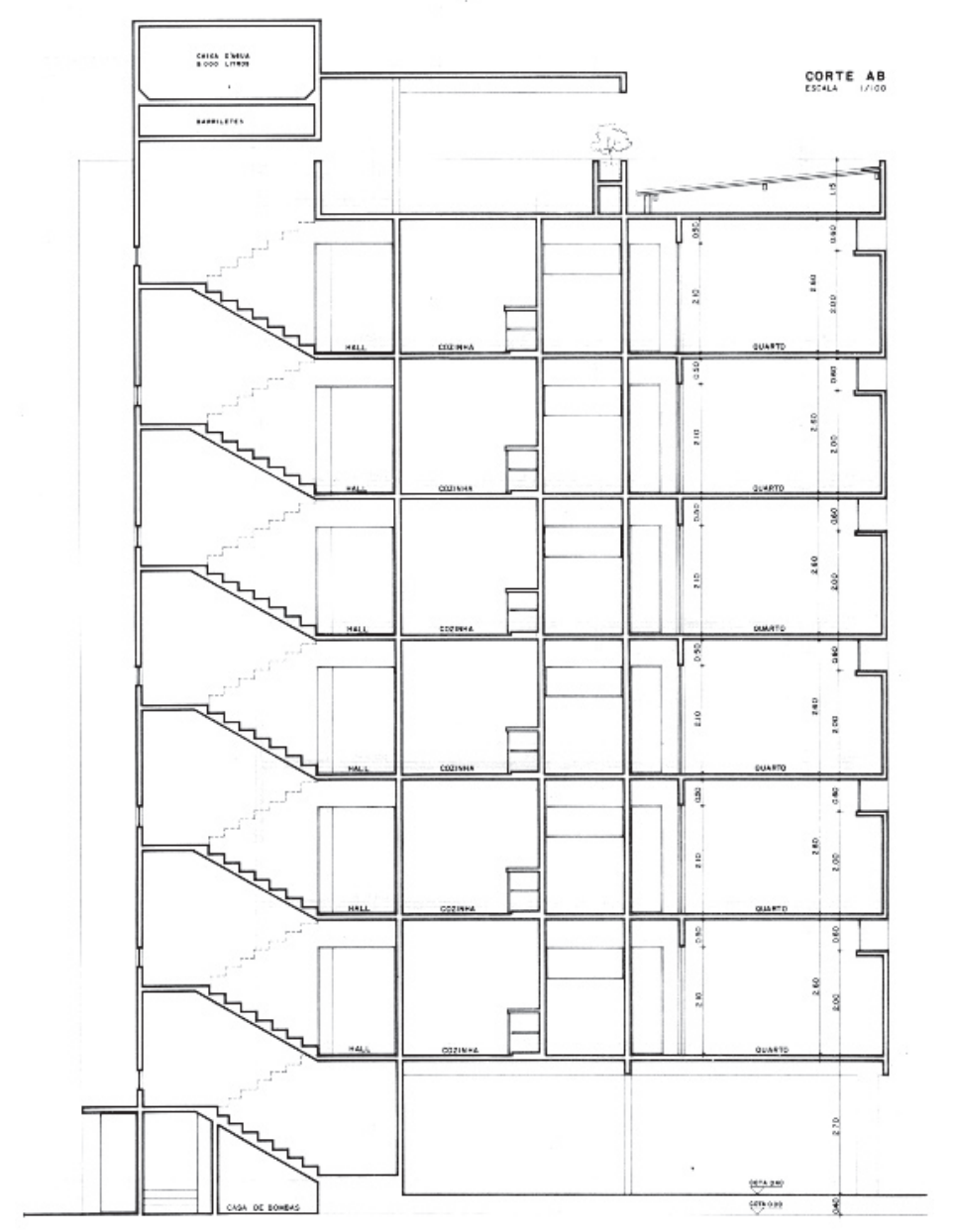


Na quarta edição, de 2002, revisada e atualizada, um novo desenho se apresenta com o intuito de registrar essas preocupações. Trata-se de um desenho em corte, numa escala ampliada, à mão livre, não com instrumentos.

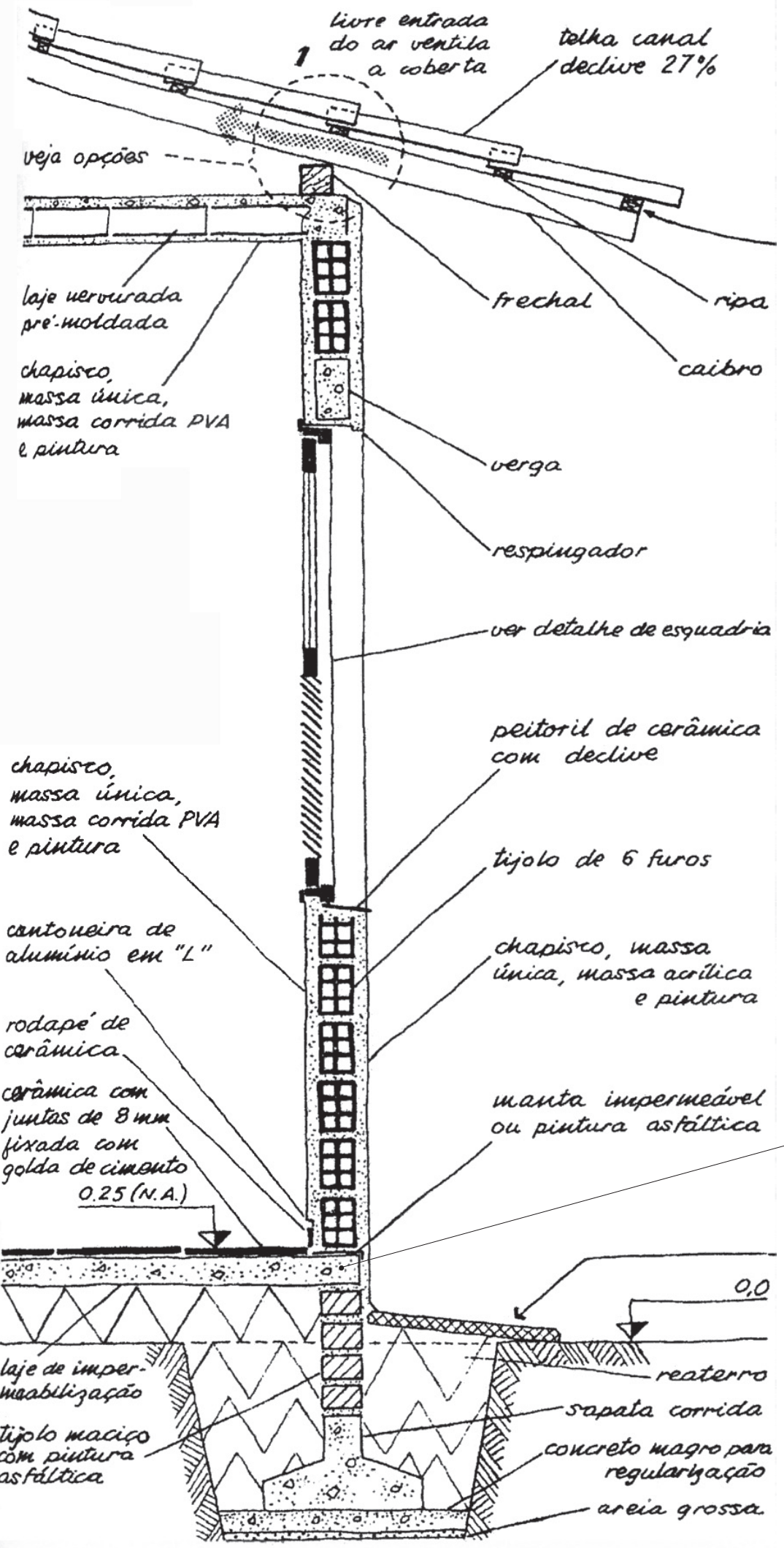

Fig.[4] 32

Desenho de um corte, p.105 (edição de 2002)
Entendimento equivocado: o lastro de concreto do piso não "monta" sobre o baldrame. A alvenaria segue direto. Numa etapa bastante posterior é que é lançado este lastro de concreto.

Além disso, seria conveniente esclarecer que há outros tipos de fundação, de acordo com as condições do terreno. 
Reserva ainda um capítulo a noções de topografia (cap.13, p.79-82) e outro a questões de circulação vertical (cap.15, p.94-108): escadas, rampas e elevador. Este último, mesmo informando através de anotações que os fabricantes fornecem todos os cálculos, medidas e capacidades do elevador, poderia ser apresentado com mais detalhes: o desenho do elevador, o contrapeso etc. 0 último desenho sobre escada (p.108) está em desacordo, hoje, com as normas vigentes do Corpo de Bombeiros. Neste sentido, deve passar por uma revisão e atualização.

Os detalhes de esquadrias (cap.17, p.112-122) se apresentam com mais consistência, com desenhos mais atualizados que o manual de Oberg. Porém, idêntico a este último, alguns elementos como o batente das portas e o requadro das janelas deveriam aparecer nos exercícios de desenhos de plantas e cortes, na escala 1:50 e maior. Isto aparece timidamente na página 64 da edição de 2002, como já ilustramos na figura 24 da página 139 deste trabalho.

Acreditamos que, pelo fato de ser professor de desenho em escola de arquitetura, vivenciando as dificuldades e demandas dos alunos, o autor elaborou, de forma mais completa que os outros, este manual. Ainda que os desenhos não registrem a materialidade e o sistema construtivo - o que enriqueceria o aprendizado do aluno -, há uma aproximação maior com a construtibilidade e, neste sentido, consideramos este manual melhor que o de Oberg. Porém, necessita também de revisões, atualizações e complementações, para contribuir para a melhoria do ensino de desenho. Na edição de 2002, alguns instrumentos "ultrapassados" de desenho foram para o final do livro, num capítulo denominado "Museu do Desenho" (Cap.22, p.158-162). Os últimos exercícios são elaborados em CAD, mas permanecem os equívocos comentados nessa análise. 


\section{Os manuais do Ching}

Temos em mãos cinco livros/manuais de Francis D. K. CHING para realizar uma breve análise: Manual de dibujo arquitectónico; Representação gráfica para desenho e projeto; Técnicas de construção ilustradas; Dicionário visual de arquitetura; e Arquitetura: forma, espaço e ordem.

Com exceção do último, todos foram listados na primeira questão do bloco D do questionário, analisado no capítulo anterior. Estas publicações têm sido cada vez mais procuradas e recomendadas pelos professores de Desenho e Projeto. Pelo menos metade dos professores que participaram do questionário adotam estes livros. A maioria consulta tanto estes como os de Oberg e de Montenegro.

Francis D. K. Ching (nascido no Havaí, em 1943) é arquiteto e professor de arquitetura na Universidade de Washington, Seattle. Segundo seu depoimento, apresentado no último livro da lista, alguns de seus trabalhos foram elaborados para introduzir uma seqüência de cursos de representação gráfica oferecidos pelo Departamento de Arquitetura daquela Universidade. Os subseqüentes desenvolvimentos se constituíram no amplo resultado de muitas discussões, sugestões e contribuições de um grupo de professores qualificados e dedicados. São também o testemunho dos esforços das conquistas e da participação crítica de muitos estudantes que testaram, de forma entusiástica, os aspectos didáticos desses materiais (CHING, Arquitetura: forma, espaço e ordem, 1999, p.VIII).

Para introduzir estes manuais no bojo das análises, vamos apresentá-los rapidamente, tendo como base os resumos de capa e contracapa de cada um deles:

O Manual de dibujo arquitectónico (México, Gustavo Gili, 3a.ed., 1999), todo ilustrado à mão, na prancheta, trata dos princípios tradicionais básicos da expressão gráfica, desde a linha à forma, assim como os sistemas de representação mais usados: o sistema diédrico, a axonometria e a perspectiva cônica. A editora Bookman, de Porto Alegre, editou no Brasil em 2000 (tradução de Luiz A. Meirelles Salgado) com o nome de Representação gráfica em arquitetura, mas não o tínhamos em mãos durante o trabalho de análise destes manuais. 
Fig.[4] 33

Capa do Manual de dibujo arquitectónico.

Fig.[4] 34

Capa do Representação gráfica em arquitetura.

Fig.[4] 35

Capa do Representação gráfica para desenho e

projeto.
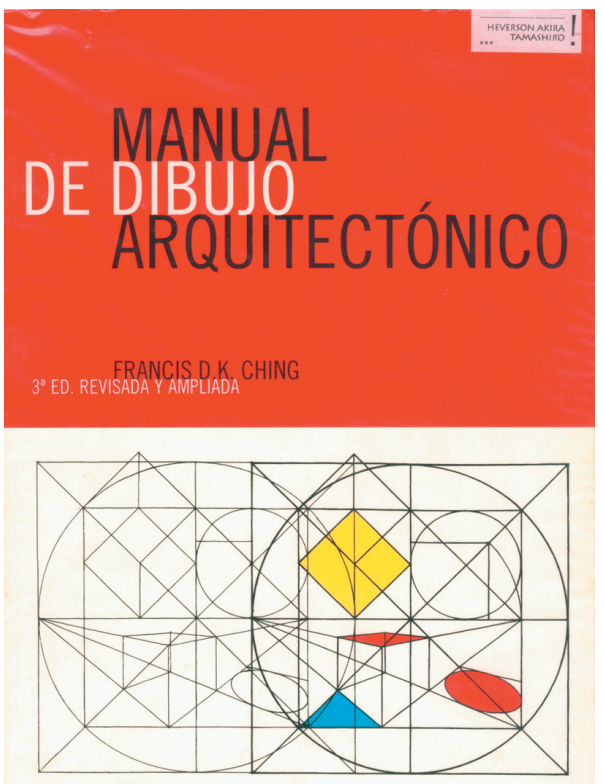

GG\%/México

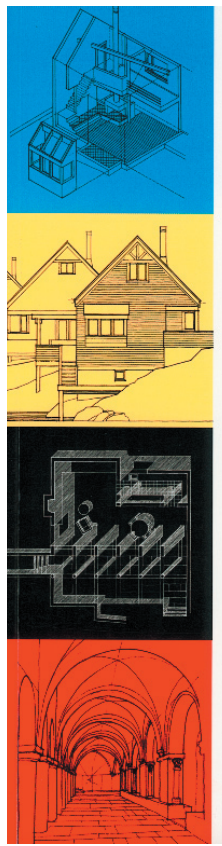

REPRESENTAÇÃO

GRÁFICA EM

ARQUITETURA

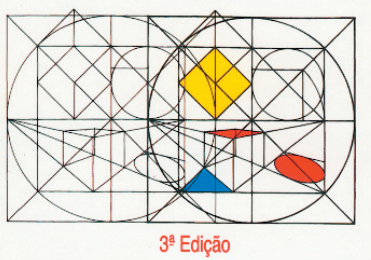

FRANCIS D. K. CHING

Em Representação gráfica para desenho e projeto (elaborado em conjunto com Steven P. Juroszek. Versão portuguesa por Anamaria Costa Martins. Barcelona, Gustavo Gili, 2001), o objetivo essencial é estabelecer relações entre as percepções, a imaginação e a representação, caracterizado pela forma de desenhar e ordenar as informações de forma que proporcione uma leitura clara a didática. Considerando a observação, a memória e a interpretação como partes de um todo inseparável, trata de desmascarar os processos cognitivos fundamentais que guiam a percepção visual e a expressão através do desenho.

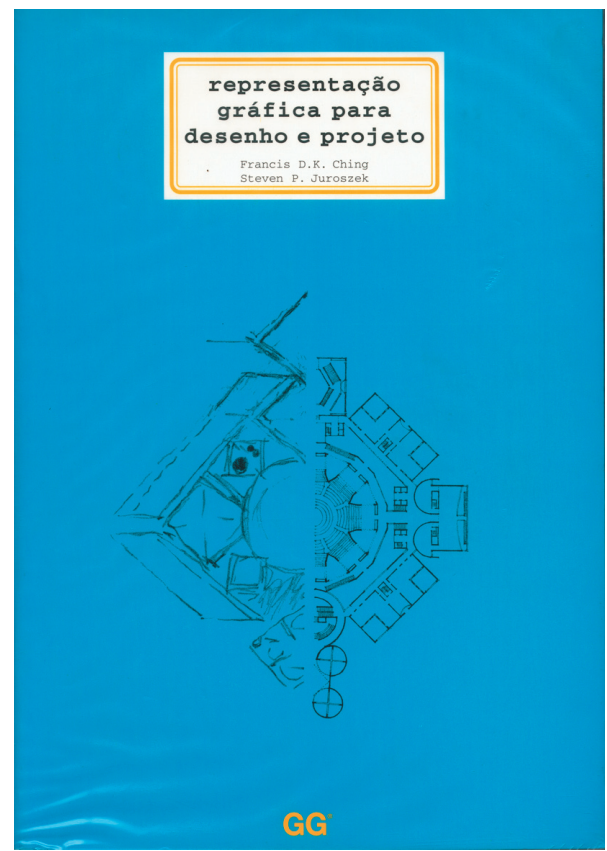


O livro Técnicas de construção ilustradas (em conjunto com Cassandra Adams. Trad. Luiz Augusto M. Salgado e equipe. Porto Alegre, Bookman, 2a.ed., 2001) apresenta ao aluno de arquitetura e ao público leigo interessado os princípios básicos da construção. Fornece uma visão geral dos principais sistemas de uma edificação, de como cada um é construído e infuenciado pelo relacionamento com os demais sistemas, abordando as estruturas de aço básicas, concreto armado e sistemas de parede-cortina.

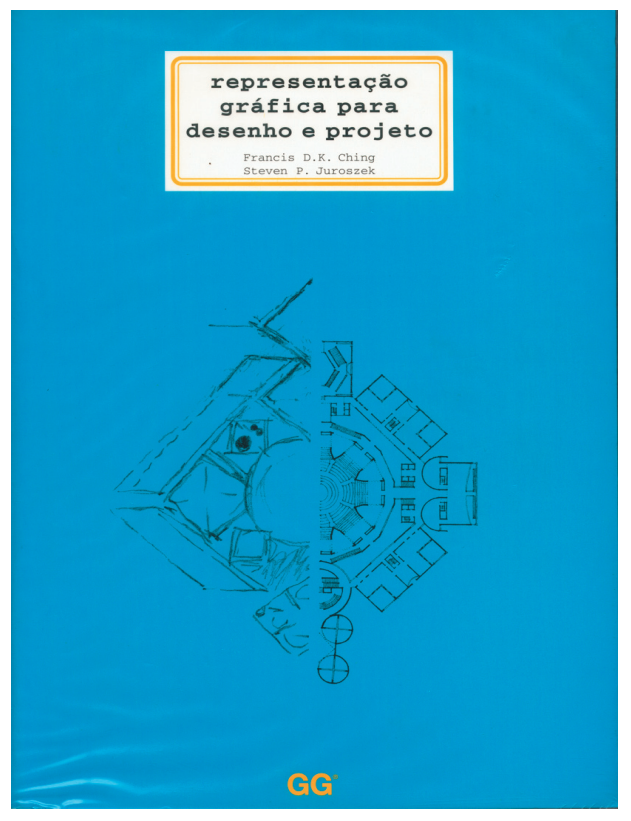

Fig.[4] 36

Capa do Técnicas de construção ilustradas.

Apresenta também as escolhas de material e estrutura disponíveis para o projetista e como essas escolhas afetam a forma, as dimensões de uma edificação e a sua relação com o local da construção. As informações são transmitidas principalmente por ilustrações, já que a imagem é fundamental na apresentação do material. Este livro é organizado de acordo com os principais componentes e sistemas de uma edificação: o local da edificação, a edificação, sistemas de fundação, sistemas de piso, sistemas de parede, sistemas de cobertura, portas e janelas, proteção contra o calor e umidade, construções especiais, acabamentos, sistemas mecânicos e elétricos e notas sobre materiais. A doutoranda do Departamento de Arquitetura da Escola de Engenharia de São Carlos, Andrea Naguissa Yuba, participou da equipe que traduziu este livro. Menciona que, assim como os outros membros da equipe, que optou-se pela não-conversão das unidades de medidas para o padrão nacional (as medidas se mantiveram na unidade de polegadas), tendo em consideração a reconhecida falta de correspondência entre os padrões praticados na América do Norte e no Brasil, o que prejudicaria a compreensão das idéias do autor do livro (YUBA, 2003).

O Dicionário visual de arquitetura (Traduzido por Julio Fischer e equipe. São Paulo, Martins Fontes, 1999) é um compêndio de termos de arquitetura totalmente ilustrado: para cada definição corresponde uma ilustração. Para garantir a mesma riqueza e detalhe de informação do original, a editora contou, quando da tradução, com uma equipe especializada que, muitas vezes, foi obrigada a estabelecer terminologia brasileira. Para tanto, foi desenvolvido um trabalho intenso de pesquisa nos inúmeros ramos de atividade ligados à arquitetura que o dicionário abrange. A relação simbólica - escreve o autor no prefácio - entre comunicação gráfica e verbal é o fundamento deste dicionário visual de arquitetura. 
Fig.[4] 37

Capa do Dicionário visual de arquitetura.

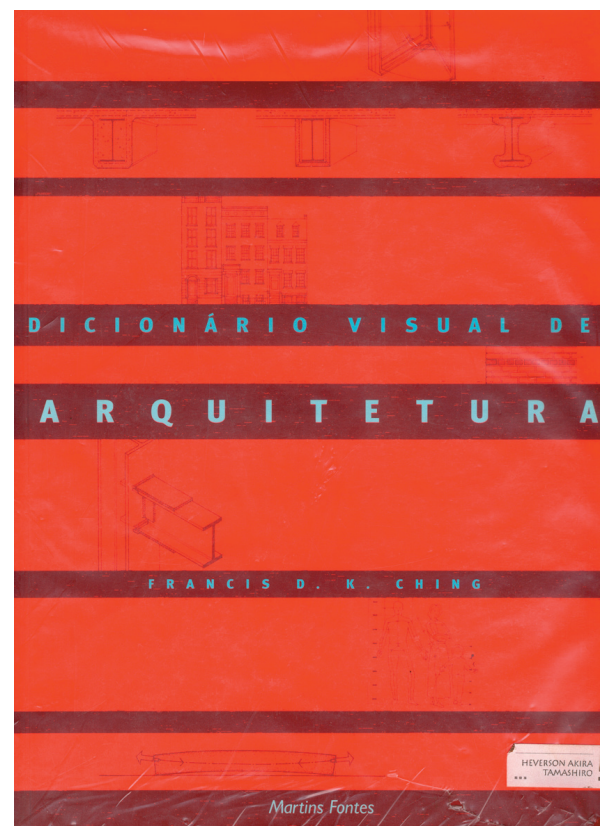

No Arquitetura: forma, espaço e ordem (Traduzido por Alvamar Helena Lamparelli. São Paulo, Martins Fontes, 1999), Ching apresenta - através de ilustrações precisas, que também servem como um guia para o desenho arquitetônico - como a forma e o espaço se interrelacionam e se organizam na construção do nosso meio. Examina, com ilustrações de protótipos arquitetônicos, o essencial da arquitetura, justapondo imagens que atravessam séculos e cruzam fronteiras culturais para criar um vocabulário elementar e definitivo do desenho. Entre os tópicos abordados encontra-se ponto, linha, volume, proporção, escala, circulação e a interdependência de forma e espaço.

Fig.[4] 38

Capa do Arquitetura: forma, espaço e ordem.

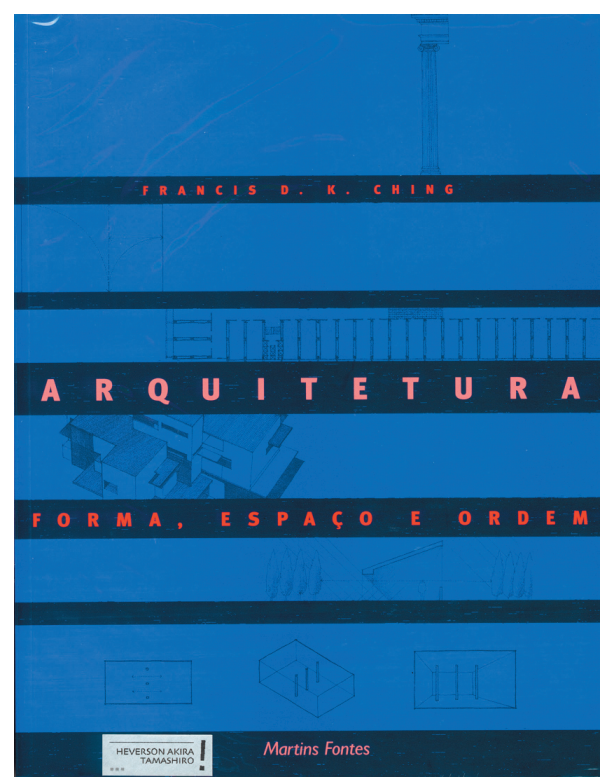

Nem todos são exatamente livros ou manuais de desenho arquitetônico, pois parte deles aborda elementos de projeto ou de tecnologia das construções. Esses últimos, consideramos verdadeiros livros que ensinam, de modo gráfico, a fazer projeto. No livro Dicionário Visual de Arquitetura, por exemplo, belos desenhos a grafite ilustram uma infinidade de detalhes construtivos que acabam nos ensinando a representar, a desenhar. E, neste sentido, tornamse manuais de desenho arquitetônico. Os ângulos das isométricas ou das perspectivas são os melhores possíveis. 
O autor e sua equipe - possivelmente deve haver uma equipe, bastante afinada com o autor, tanto em pensamento como em semelhança de traço - não economizam esforços: elaboram cortes perspectivados, perspectivas explodidas, ilustrações agradáveis e bastante didáticas. 0 autor demonstra facilidade de se comunicar pelo desenho, poder de síntese, entendimento do que está apresentando etc. e, sobretudo, domínio incontestável e absoluto do traço. O limite entre o ensino de desenho e de projeto é difícil de estabelecer, pois o autor habilmente flui de um assunto a outro, através dos melhores exemplos possíveis, tanto na representação gráfica em si como na escolha da situação e do objeto arquitetônico representado.
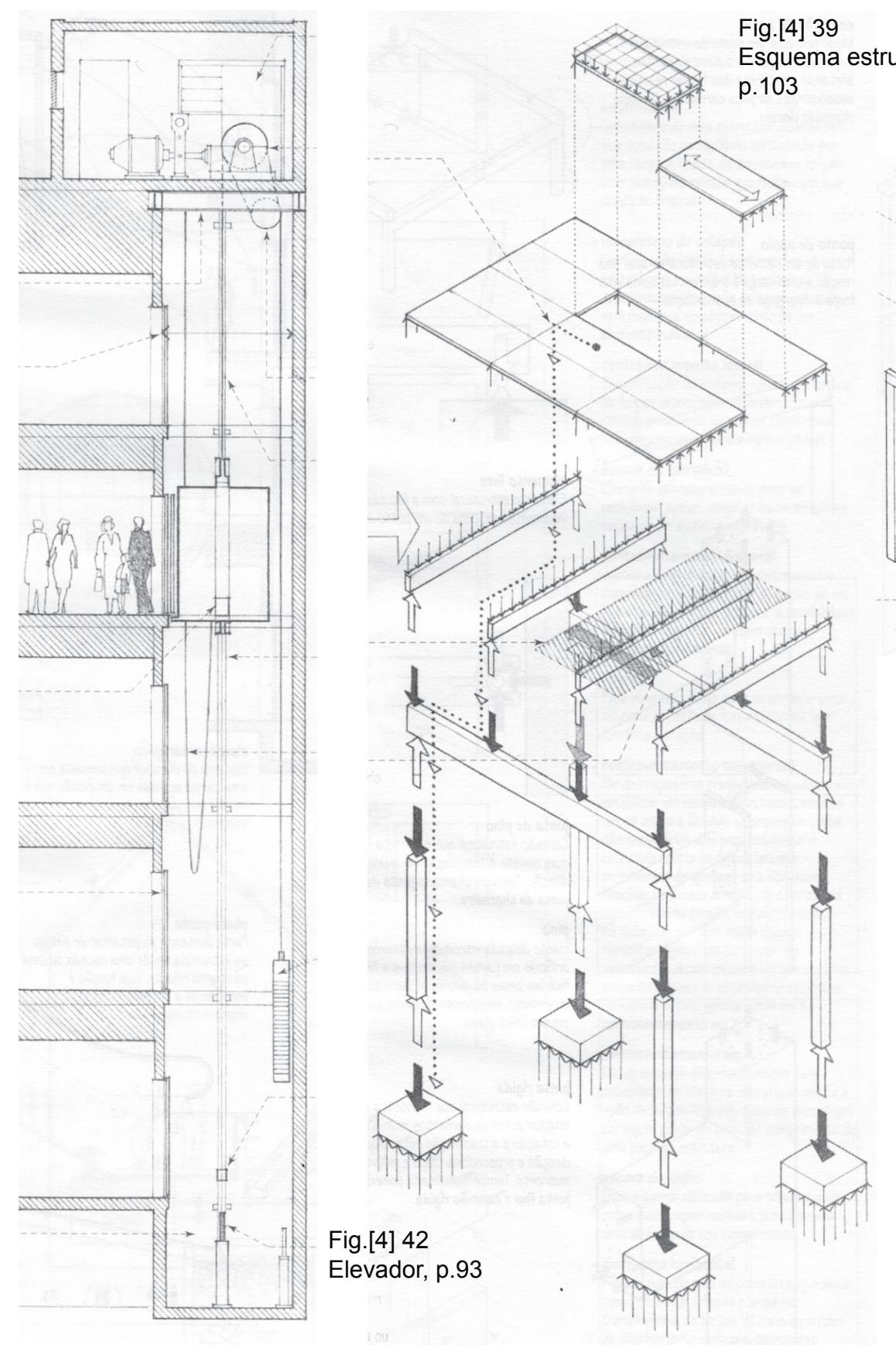

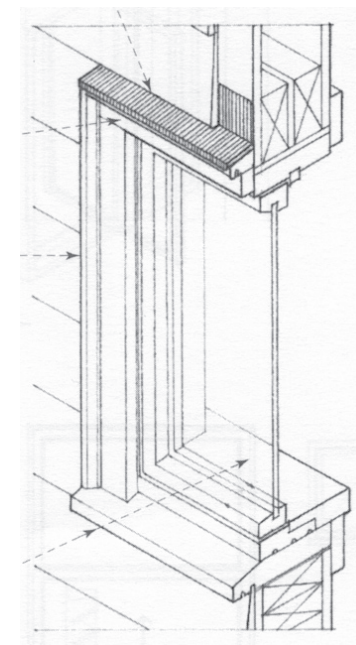

Fig.[4] 40

Detalhe de janela 1 , p.155

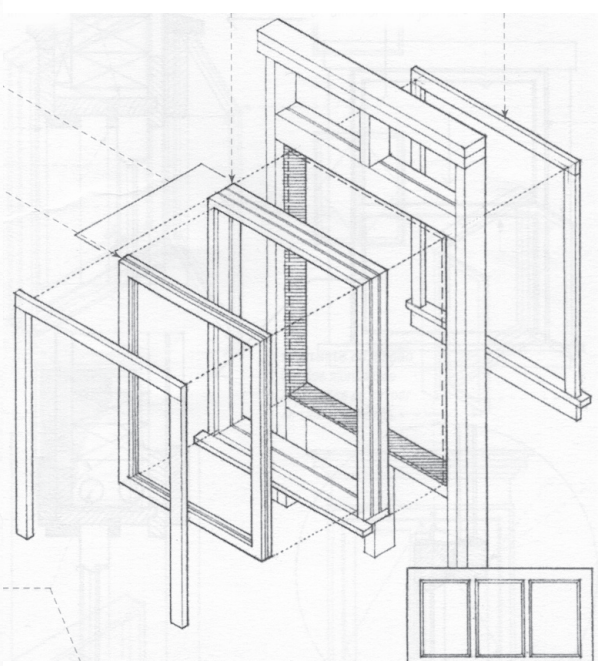

Fig.[4] 41

Detalhe de janela 2, p.155

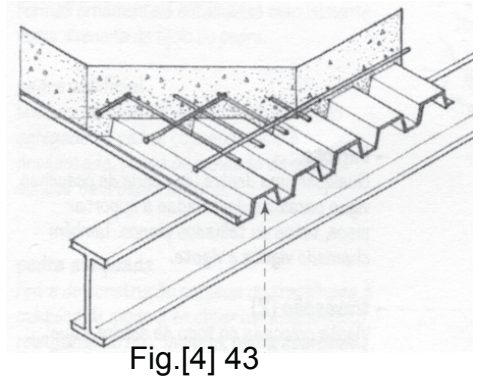

Form decking, p.220

Todas as ilustrações desta página foram extraídas do Dicionário Visual de Arquitetura. 
No livro Arquitetura: forma, espaço e ordem, os desenhos - igualmente belos e exemplares - sintetizam a leitura e análise da forma de projetos de arquitetos importantes, tratando-se mais de questões relativas a projeto do que propriamente de desenho. Contudo, esse livro não deixa de ser um elemento formador de repertório dos vários modos de representação gráfica

Fig.[4] 44 Residência Gwathmey, p.49 em arquitetura.

Fig.[4] 45

Edifício John Deere \& Company, p.88
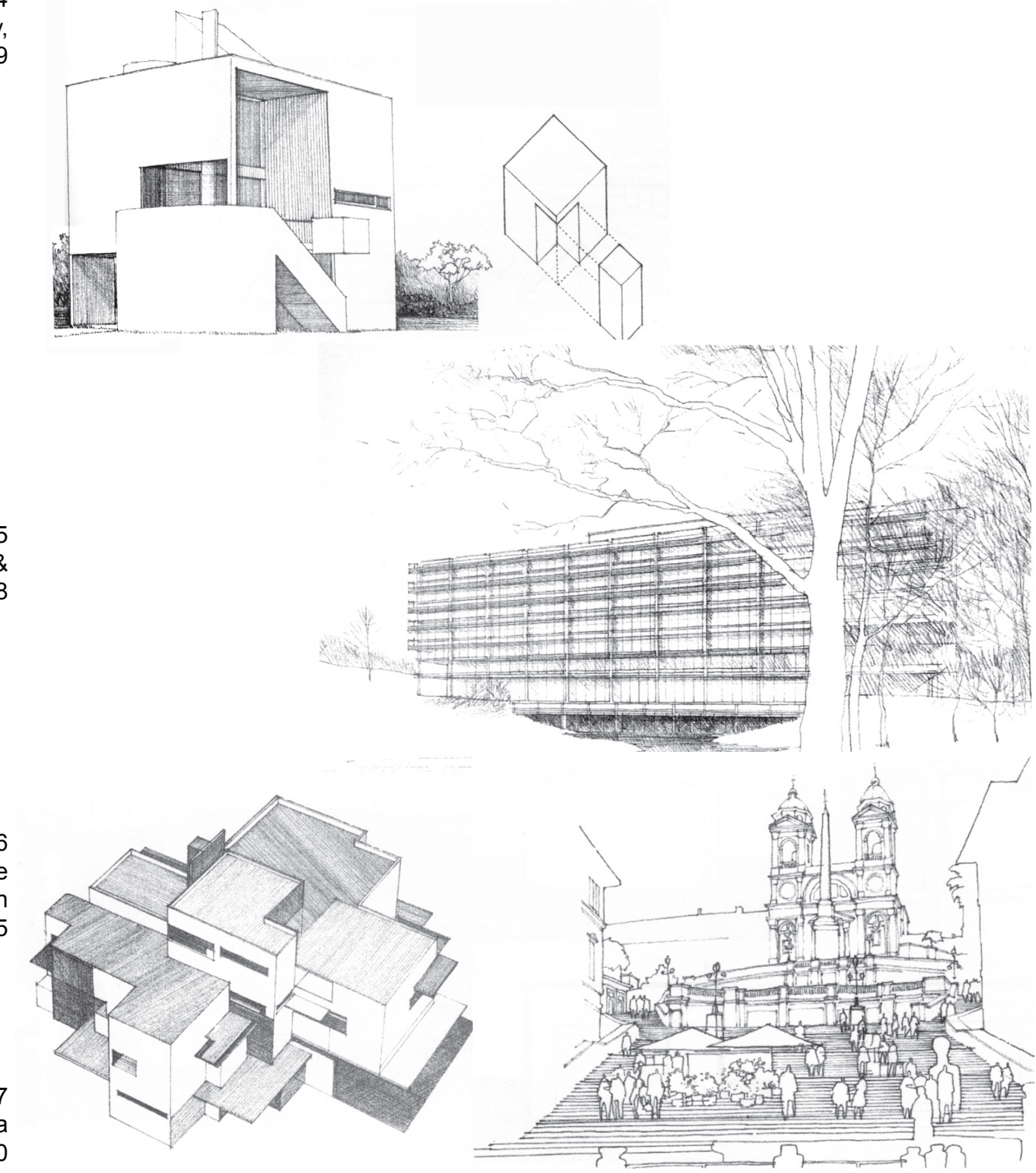

Estudo de projeto de Van Doesburg e Van Esteren, p.85

Fig.[4] 47 Escada da Espanha

(Roma), p.20

Fig.[4] 48

Casa de Vidro, Philip Johnson, p.117

Todas as ilustrações desta página foram extraídas do Arquitetura: forma, espaço e ordem.

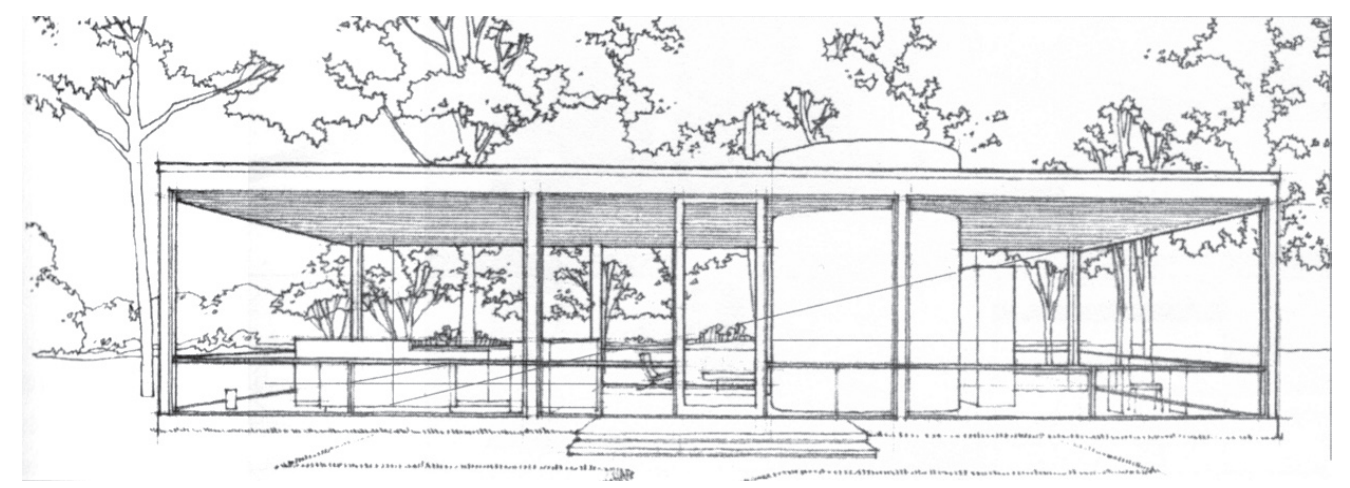


O livro Manual de dibujo arquitectónico é o que mais se aproxima do autêntico manual de desenho arquitetônico. Nele aparecem, de maneira bastante didática, o ensino de desenho de plantas, cortes, vistas e perspectivas ou isométricas, a representação de simbologias (código) e a caligrafia. Além disso, há um número de páginas considerável dedicado a desenhos à mão livre, representação de figura humana, vegetação (árvores, plantas, texturas de piso vegetal, automóveis etc. Para finalizar, o autor expõe, didaticamente, os diagramas gráficos, que estimulam o pensamento visual, e trata da apresentação e exposição dos desenhos (composição, diagramação, formatos de apresentação etc). De todos os manuais analisados, incluindo os de Oberg e de Montenegro, é o que mais claramente nos transmite o cuidado com o grafismo e suas possibilidades de expressão. É, também, o livro que apresenta, passo a passo, a sequiência do desenho, por exemplo, de uma planta de arquitetura. Além disso, explora o valor tonal do grafismo, tanto nos desenhos de plantas, cortes e vistas como nas vistas perspectivas. 0 autor escreve:

A base de quase todo desenho arquitetônico é a linha e a sua essência é a sua continuidade. Num desenho de linhas puras, a informação arquitetônica nela contida (volumetria do espaço; definição dos elementos planos, sólidos e vazios; profundidade) depende, em grande parte, das diferenças discerníveis do peso visual dos tipos de linhas utilizados (p.11).

\section{DUREZA DE MINA RECOMENDADA:}

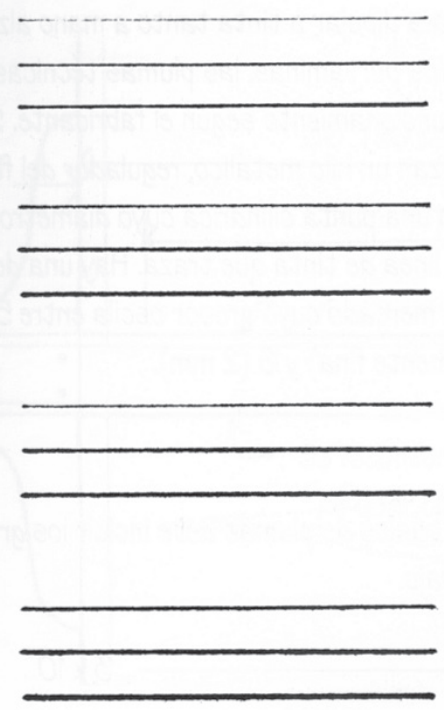

4H - dura y densa

- para planos exactos

- no para dibujos acabados

- no presionar mucho al dibujar; deja marcas en el papel y no se borra con facilidad

- no se pueden sacar buenas copias

2H - semidura

- el grado más duro posible para dibujos acabados

- no se borra fácilmente si se dibuja fuerte

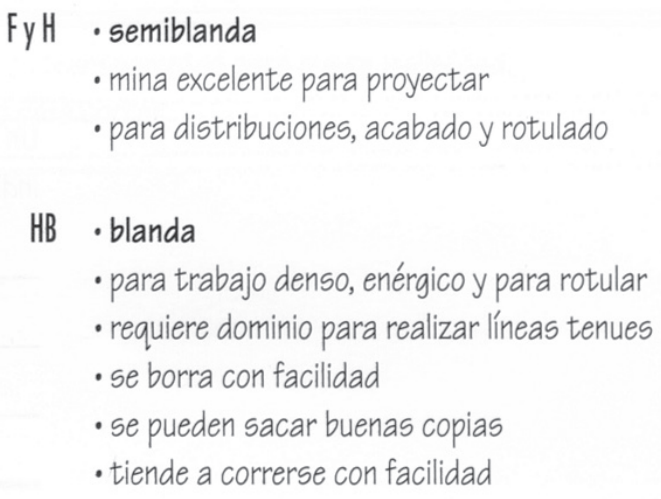

Fig.[4] 49

Dureza da mina do lápis, p.3
Todas as ilustrações
desta página até a
página 157 foram
extraídas do livro
Manual de dibujo
arquitectónico. 
Fig.[4] 50

Projeções ortogonais do desenho arquitetônico,

p.18

Fig.[4] 51

Explicando a planta,

p.18

Fig.[4] 52

Explicando o corte, p.34
Aunque estos cuatro objetos tienen formas distintas, las plantas (mirando verticalmente hacia abajo) son idénticas. Por esta razón, la relación entre planta, sección y alzado es básica para la descripción y comprensión de lo que se está dibujando. Cuando utilizamos plantas, secciones y alzados para describir arquitectura, tenemos que ver estos dibujos como una serie de vistas relacionadas. Todas ellas contribuyen a todo lo que estamos dibujando.
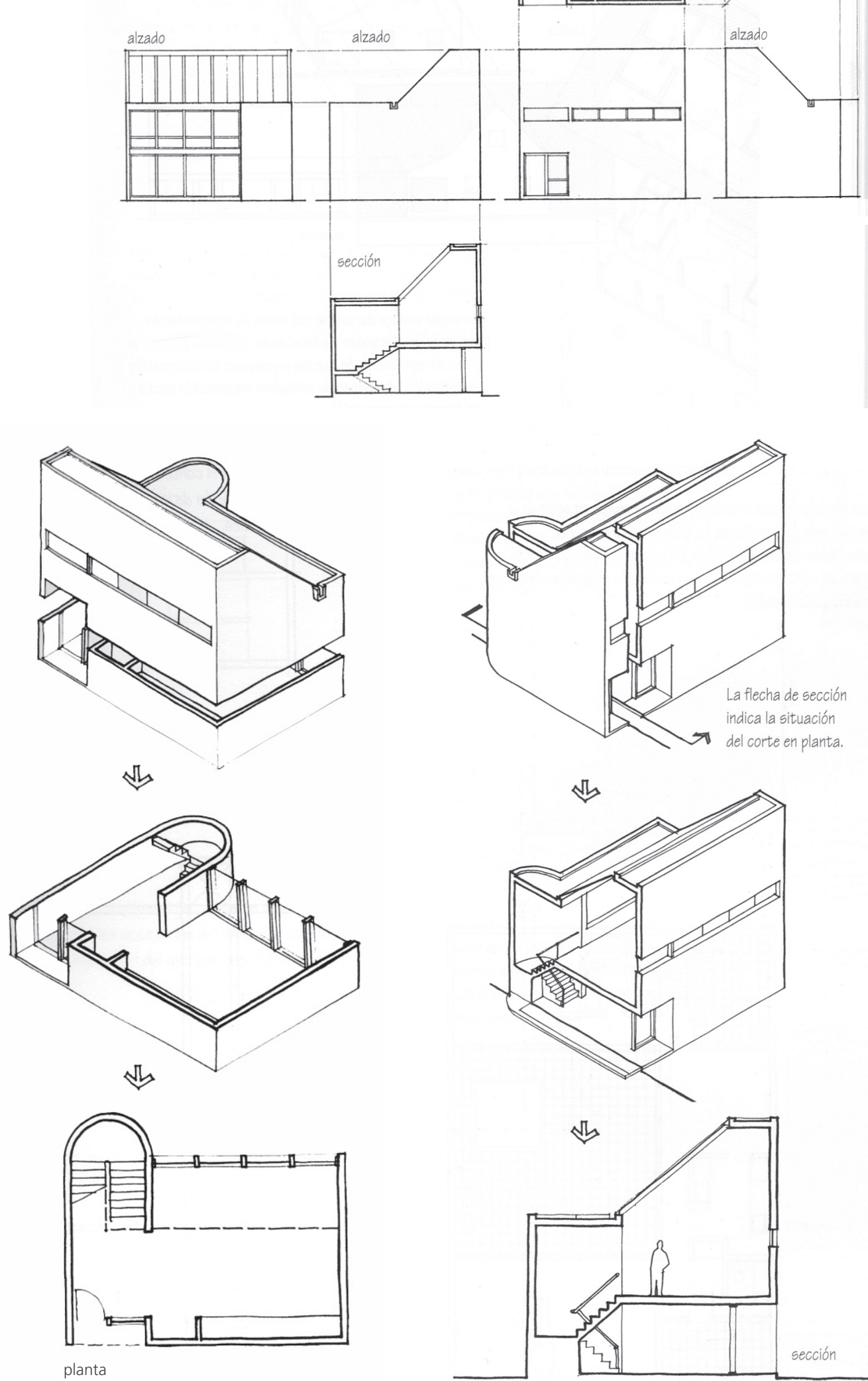


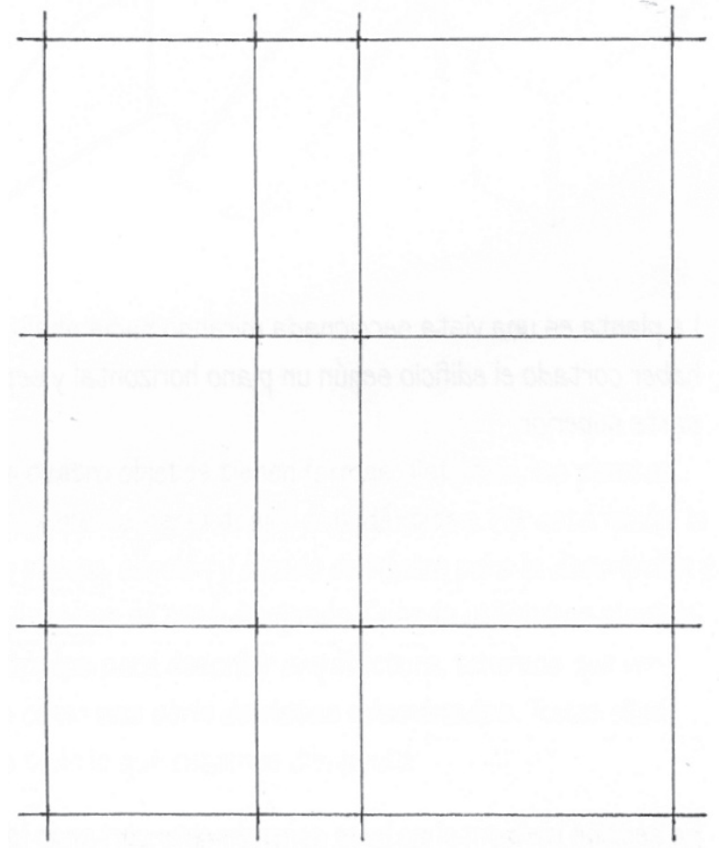

Linhas auxiliares que estruturam o desenho

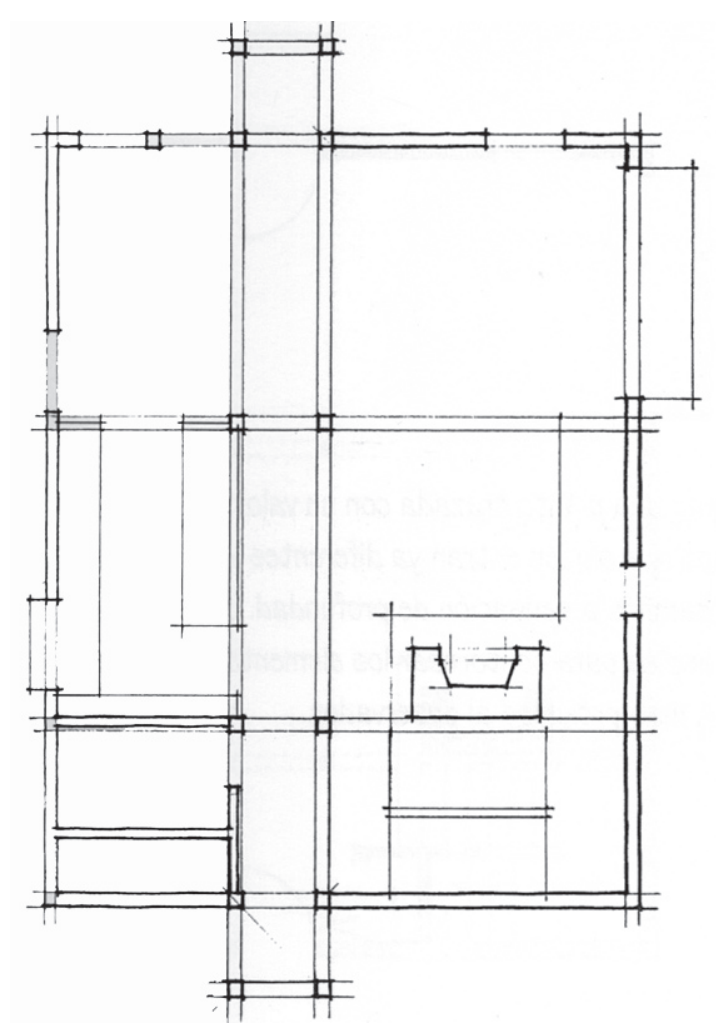

Com linhas firmes e fortes vai se delineando as paredes em corte, deixando os vão de portas e janelas

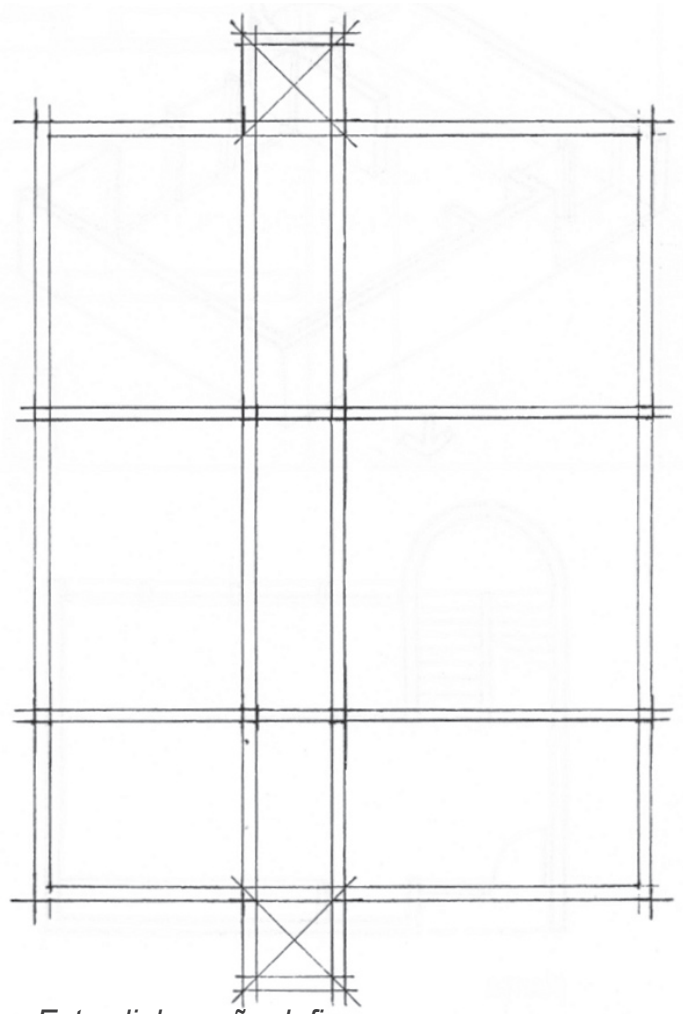

Estas linhas vão definindo as paredes

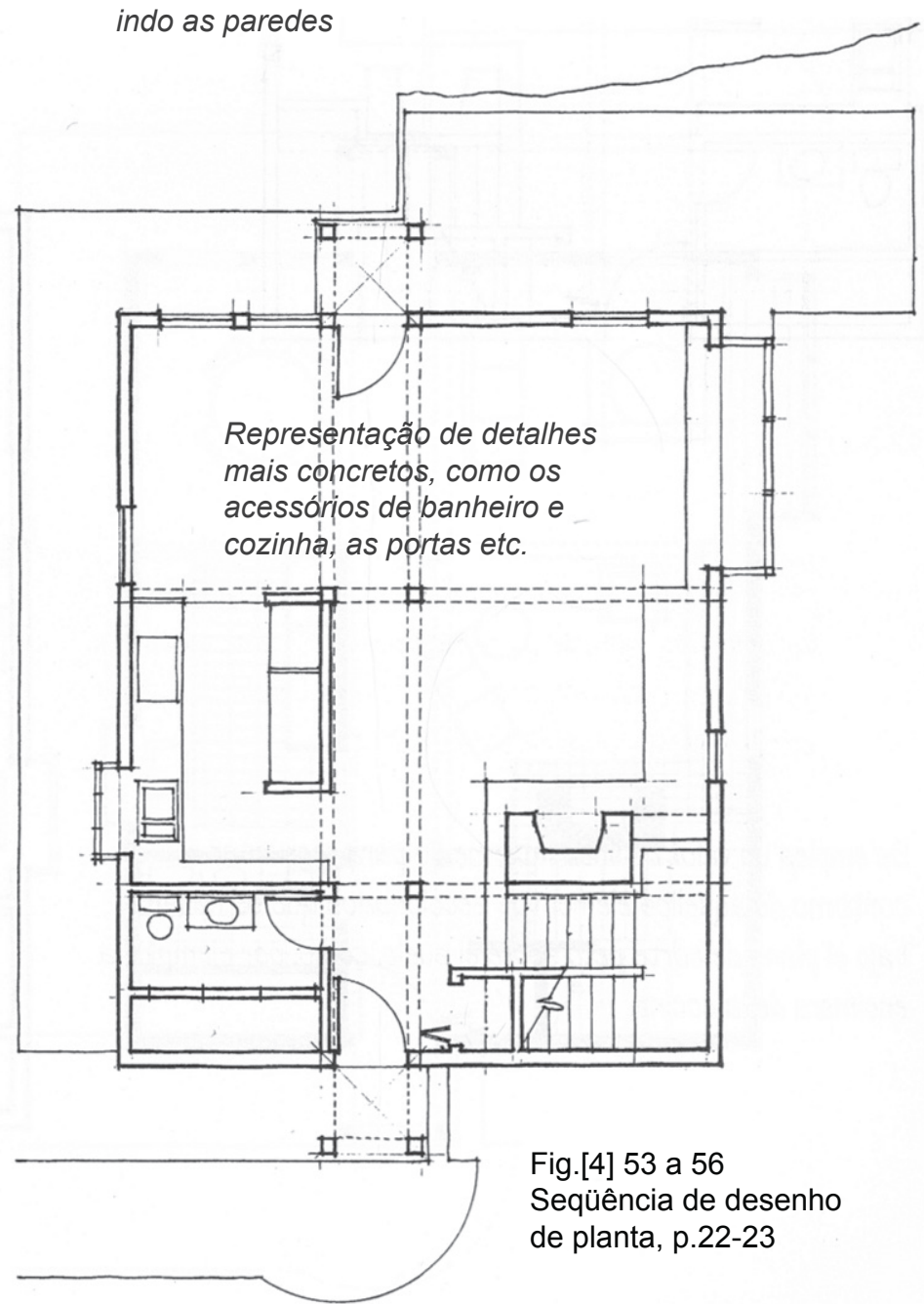




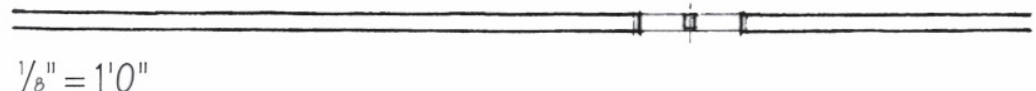

$$
1 / 8^{\prime \prime}=1^{\prime} 0^{\prime \prime}
$$

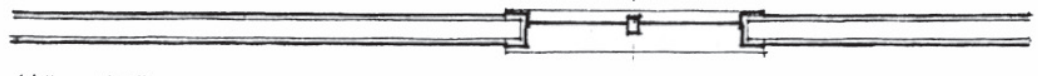

$$
1 / 4^{\prime \prime}=1^{\prime} 0^{\prime \prime}
$$
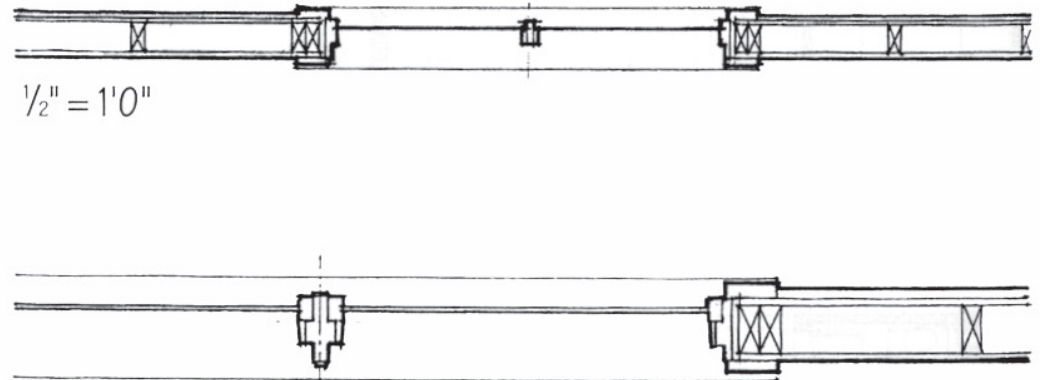

$3 / 4^{\prime \prime}=10^{\prime \prime}$

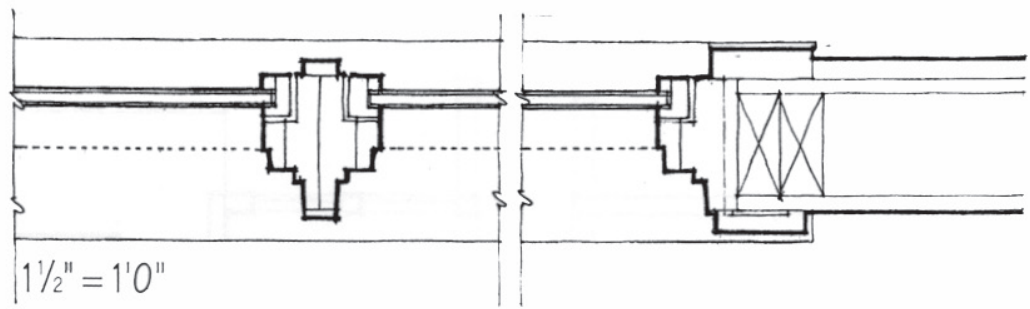

Fig.[4] 57

Desenho de planta em várias escalas, p.24

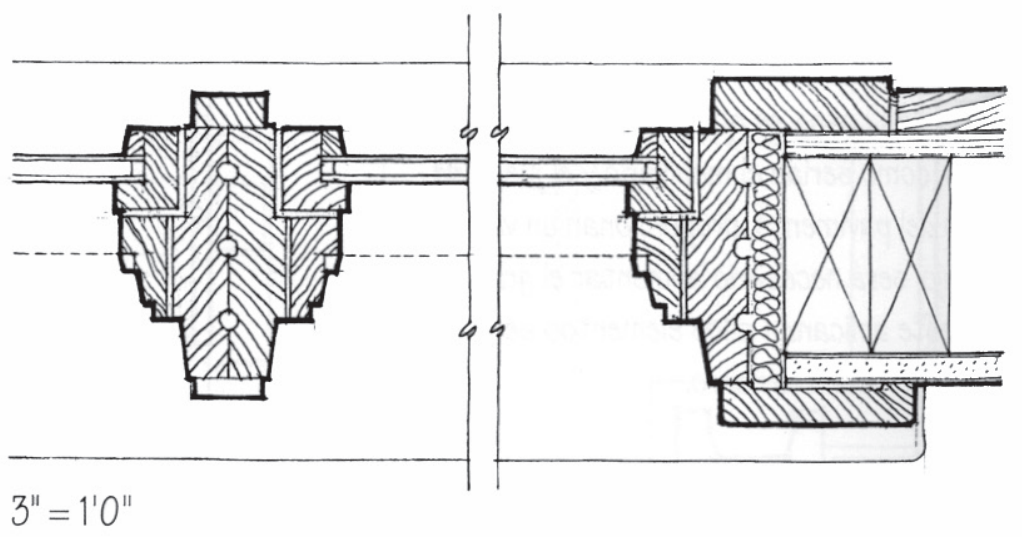

Conforme se aumenta a escala do desenho, aumenta o nível de detalhes indispensável para garantir a credibilidade da representação gráfica. A atenção devida ao detalhe se acentua quando se desenham as espessuras dos materiais [...] Para elaborar desenhos em planta em escalas maiores é necessário, por conseqüência, ter conhecimentos gerais de construção (CHING, Manual de dibujo arquitectónico, 1999, p.24). 


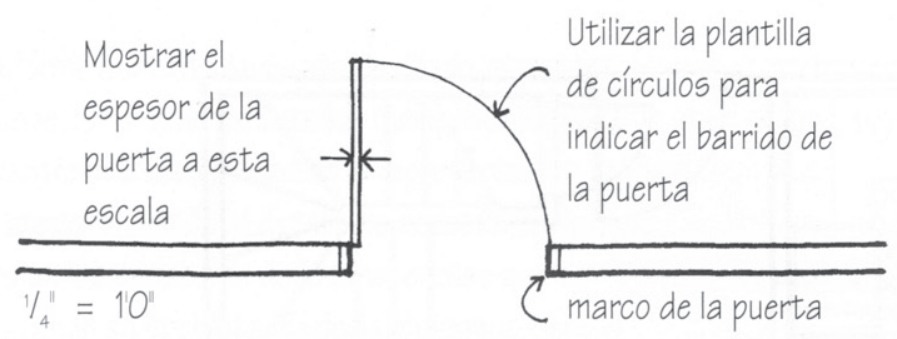

Fig.[4] 58

Portas e janelas em

planta, p.26
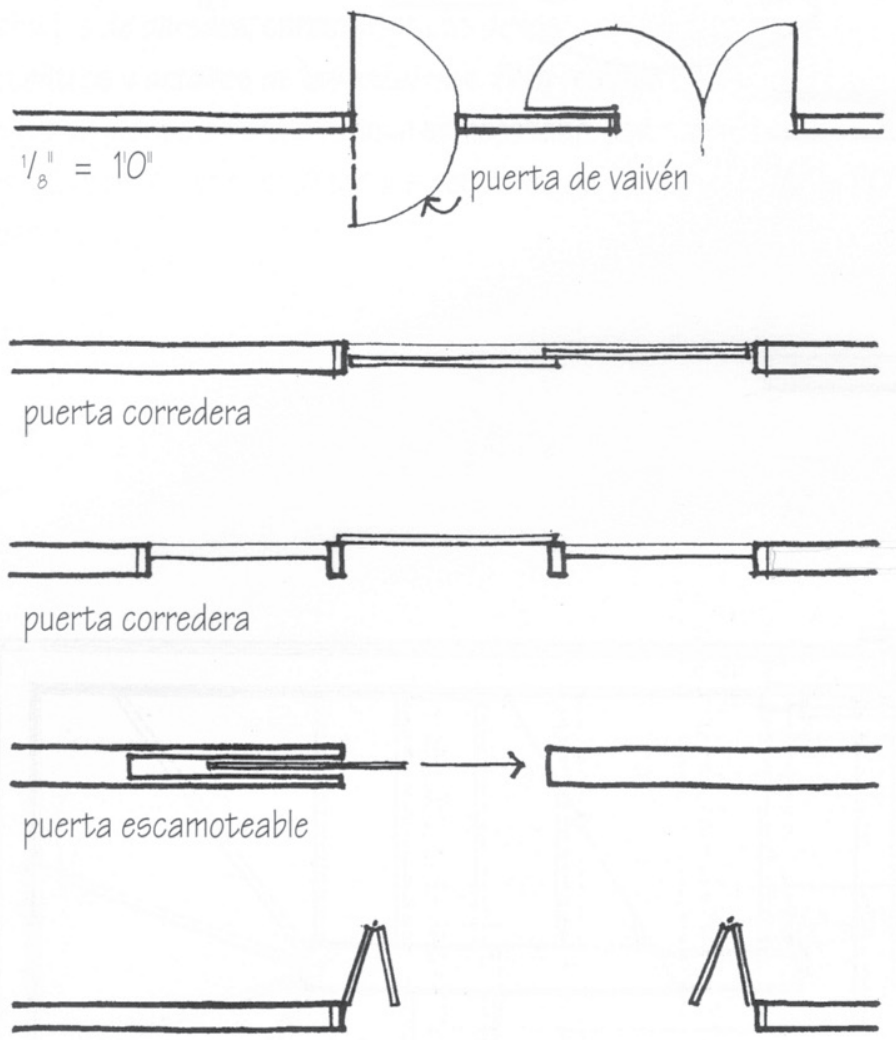

puerta plegable

línea de la

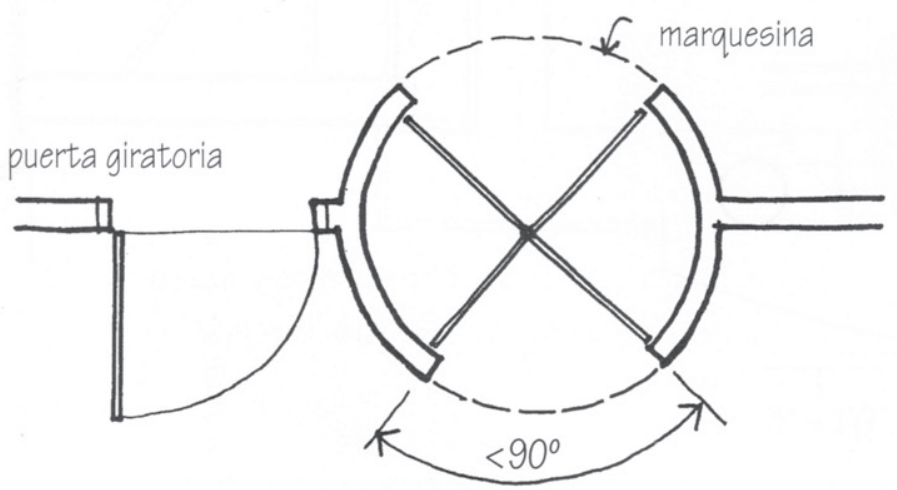


Fig.[4] 59

Secção de desenho,

p.39
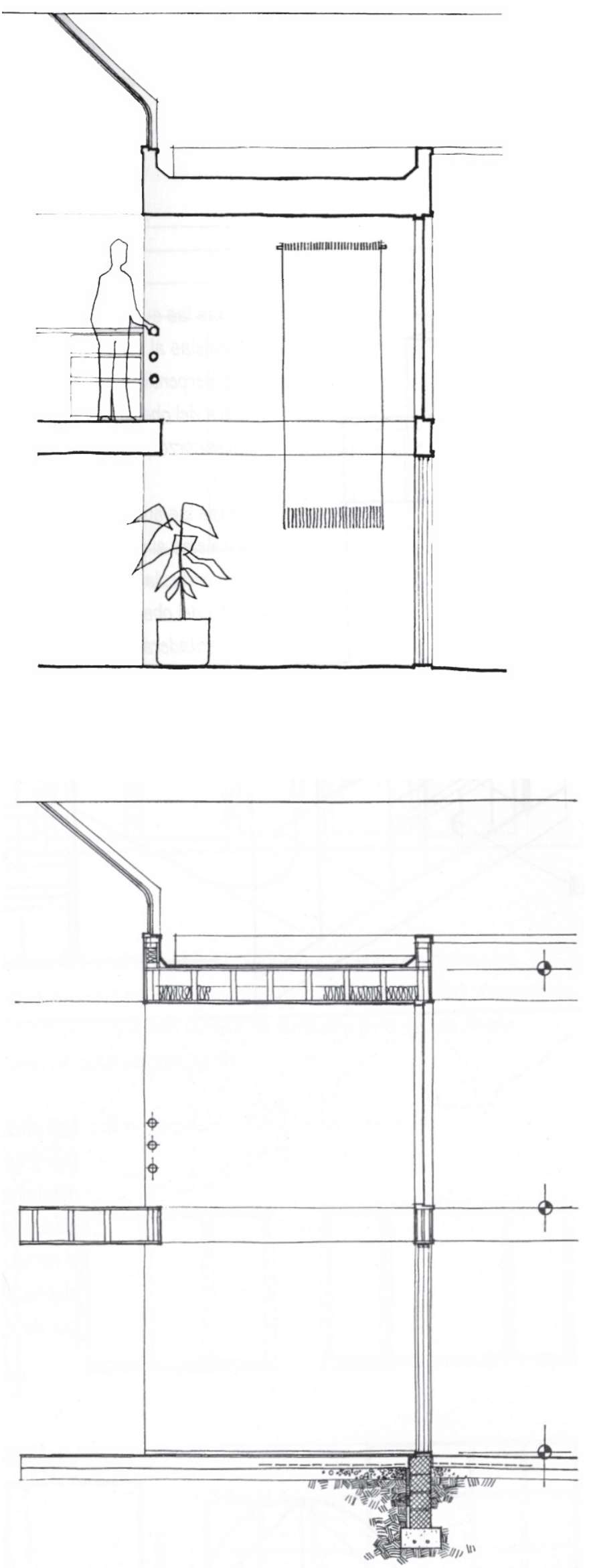

Os cortes ou secções ajudam a ilustrar o entorno e o contexto físico de um edifício e as relações entre o espaço construído e espaços exteriores.

A secção de desenho dá ênfase na forma e na definição do espaço, enquanto que a secção de construção enfatiza os detalhes de construção do edifício, onde os materias de construção e o sistema construtivo se apresentam de forma mais clara.
Fig.[4] 60

Secção da construção,

p.39 


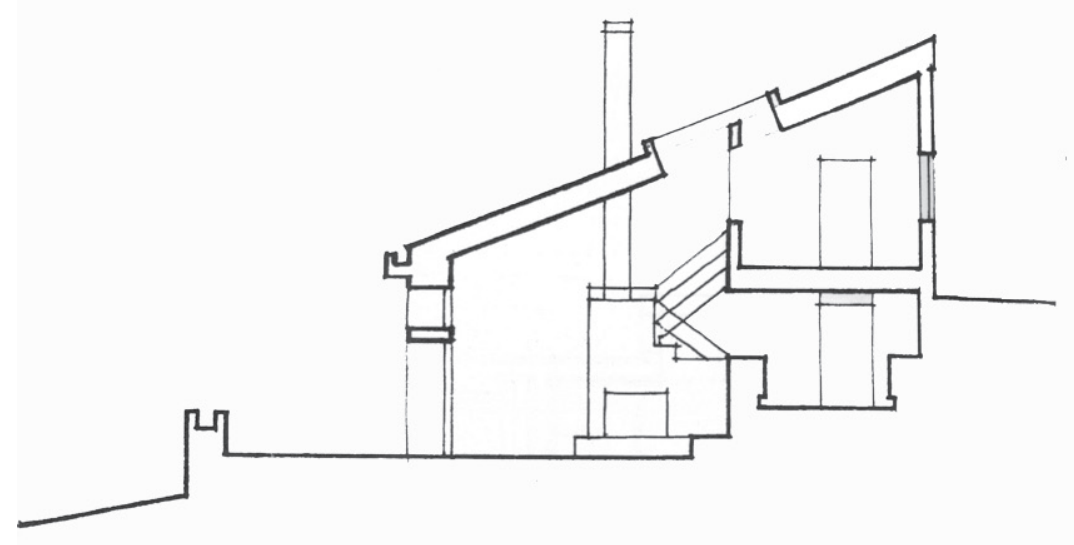

Fig.[4] 61

Exploração do valor tonal do grafismo, p.100

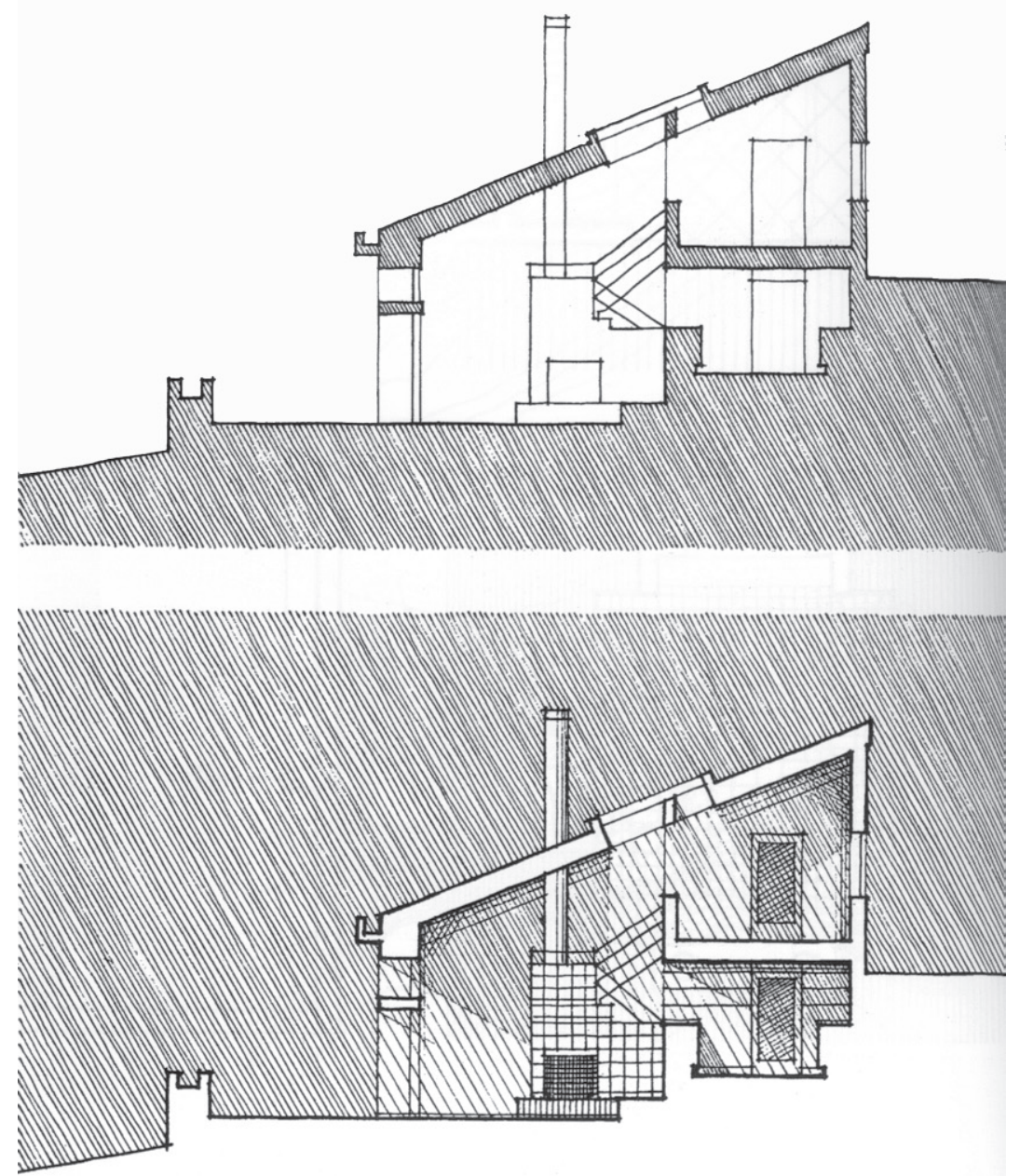

A principal utilidade dos valores tonais num corte é que são um meio de contrastar os elementos seccionados e o que se vê em vista mais além do plano de corte. No primeiro desenho observa-se que tais elementos se engrossam. No segundo, destaca-se mediante um valor tonal escuro, enquanto que no terceiro, inverte-se o sistema tonal e os elementos seccionados se destacam sobre um fundo escuro. Nos dois últimos desenhos a relação se estabelece entre a forma construtiva e o terreno se põe de manifesto representando explicitamente a secção dele mesmo, ganhando igual tratamento que o edifício (CHING, Manual de dibujo arquitectónico, 1999, p.100). 


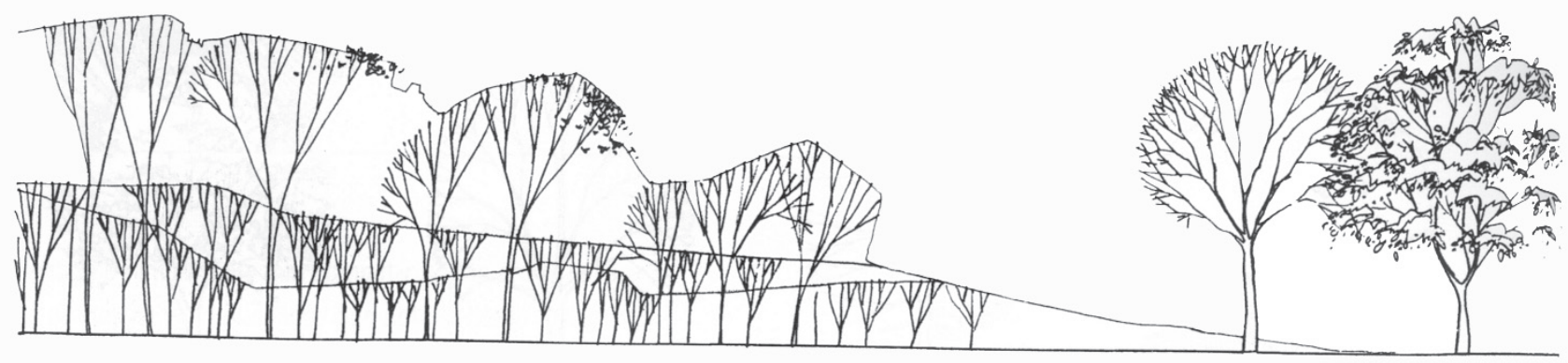

Fig.[4] 62

Árvores e paisagens,

p.136

y que ser económico. El estilo de un dibujo arquitectónico ne que ser consecuente en todos sus aspectos: entorno ujado a mano alzada en un plano a mano alzada; entorno ineado (abstracto si hace falta) en un plano delineado. cantidad de detalles representados tiene que ser isecuente con la escala del dibujo.

Fig.[4] 63 Árvores e paisagens, p.135
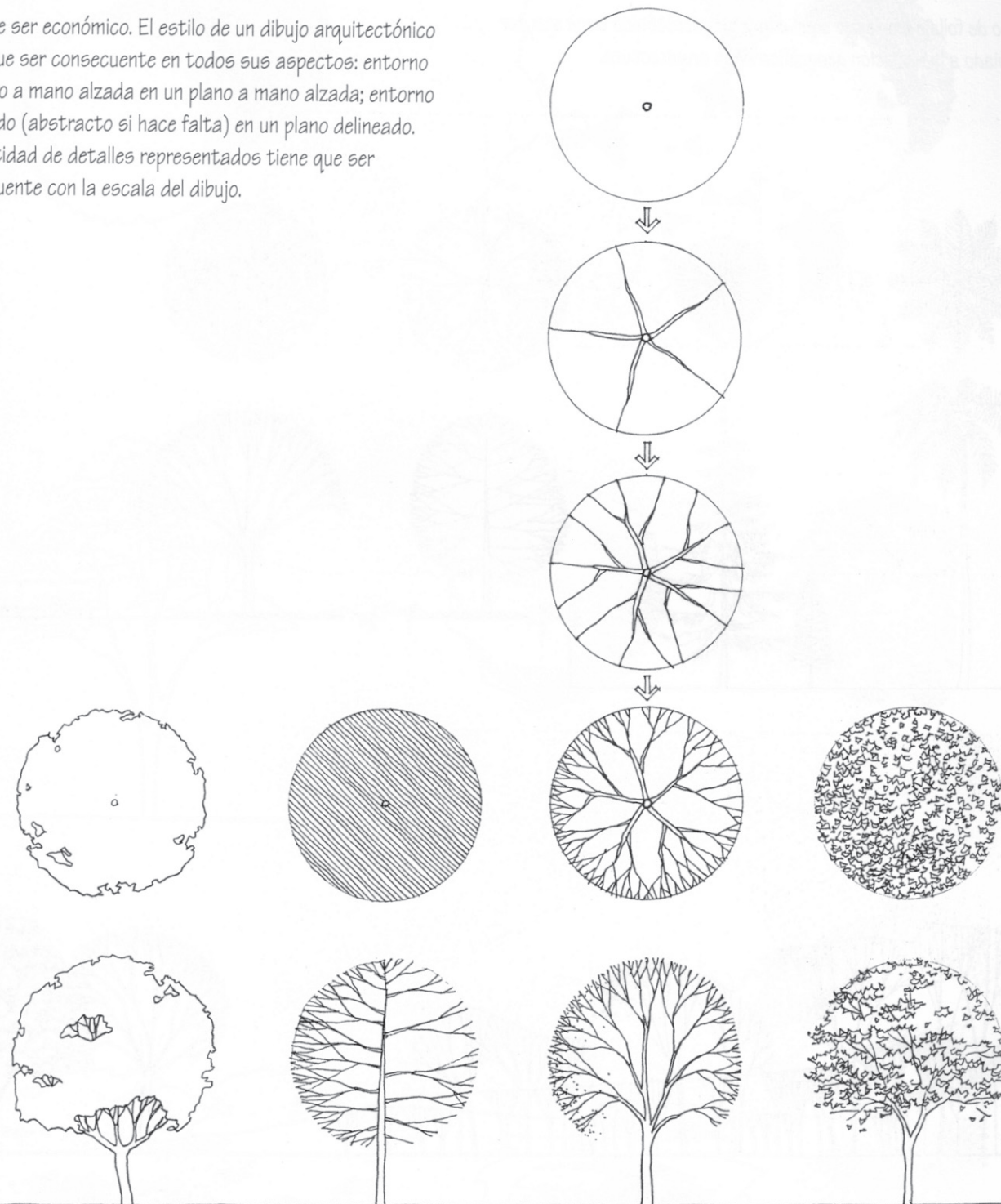
consulta na questão que reivindicamos, de que o desenho arquitetônico deva registrar as soluções dos sistemas estruturais e a materialidade da construção. Apresenta, didaticamente, em planta, vistas e cortes, além de projeções isométricas, as soluções construtivas. Mesmo sabendo que muitos materiais ou sistemas construtivos não se viabilizariam aqui no Brasil - trata-se de soluções americanas -, remetem-nos a criar soluções adaptadas ao nosso modo de construir. Como nosso trabalho se atém ao recorte do desenho e ao fato de que este desenho deva representar os materiais e a construtibilidade, este é o melhor livro, entre os cinco, desse ponto de vista, já que essas situações aparecem com propriedade e riqueza de detalhes.

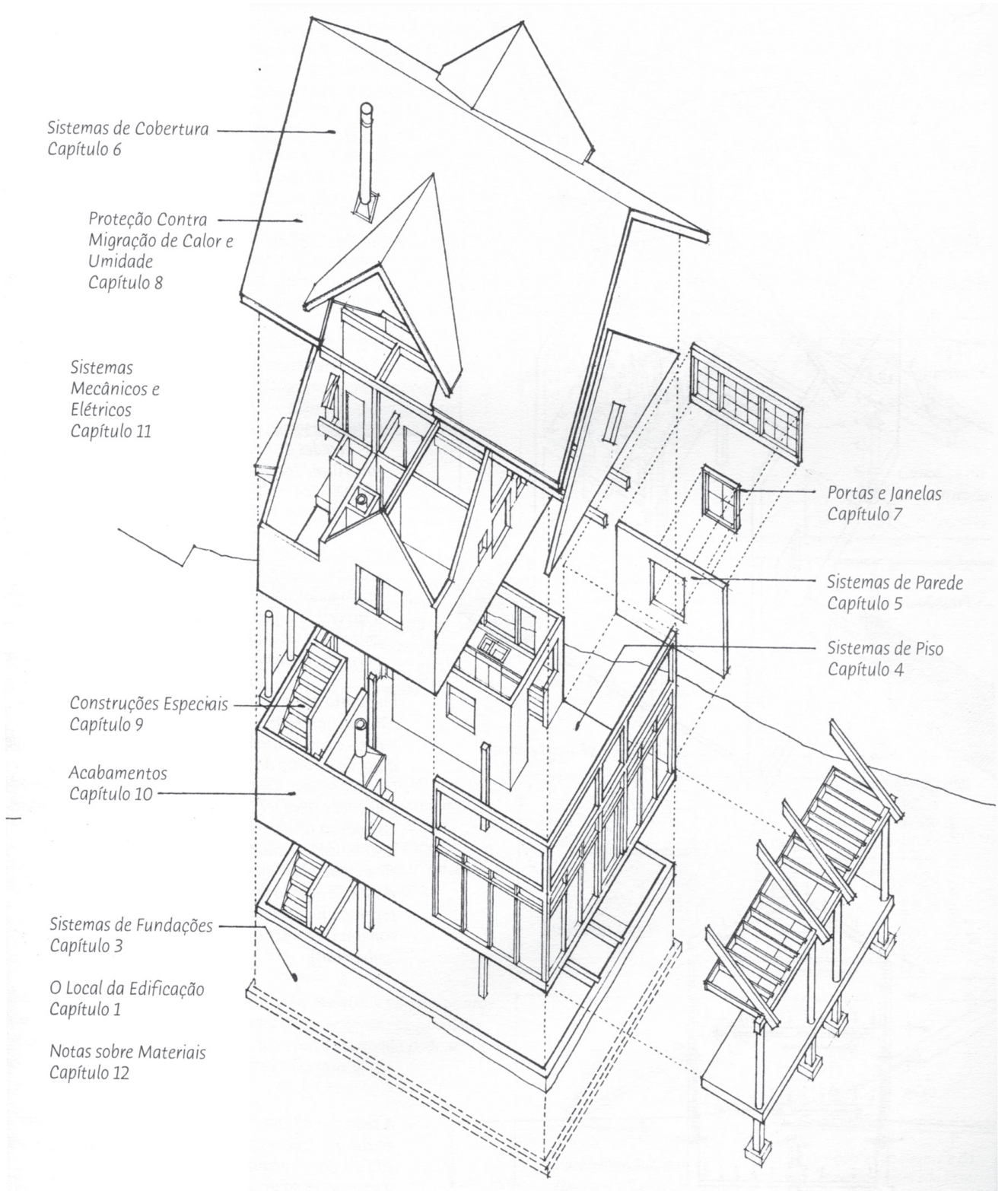

Fig.[4] 64

Axométrica explodida apresentando os elementos de uma edificação, p.2.9.
Todas as ilustrações desta página até a página 160 foram extraídas do livro Técnicas de construção ilustradas. 
Fig.[4] 65

Dispositivos de ancoragem em estruturas metálicas,

p.5.41.
Fig.[4] 66

Detalhe de estrutura de cobertura em aço, p.6.20.

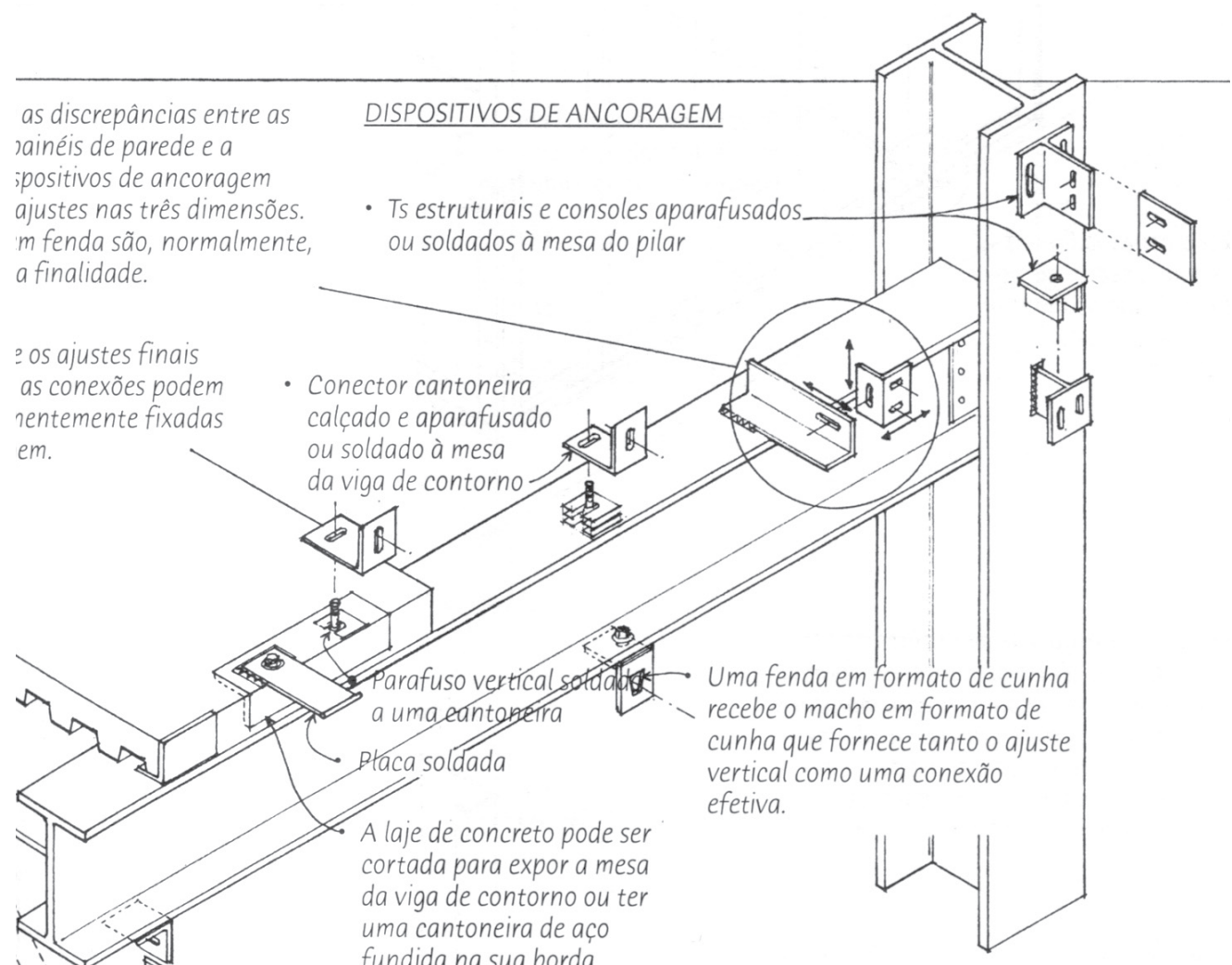

Um apoio horizontal pode ser suspenso da viga de contorno.

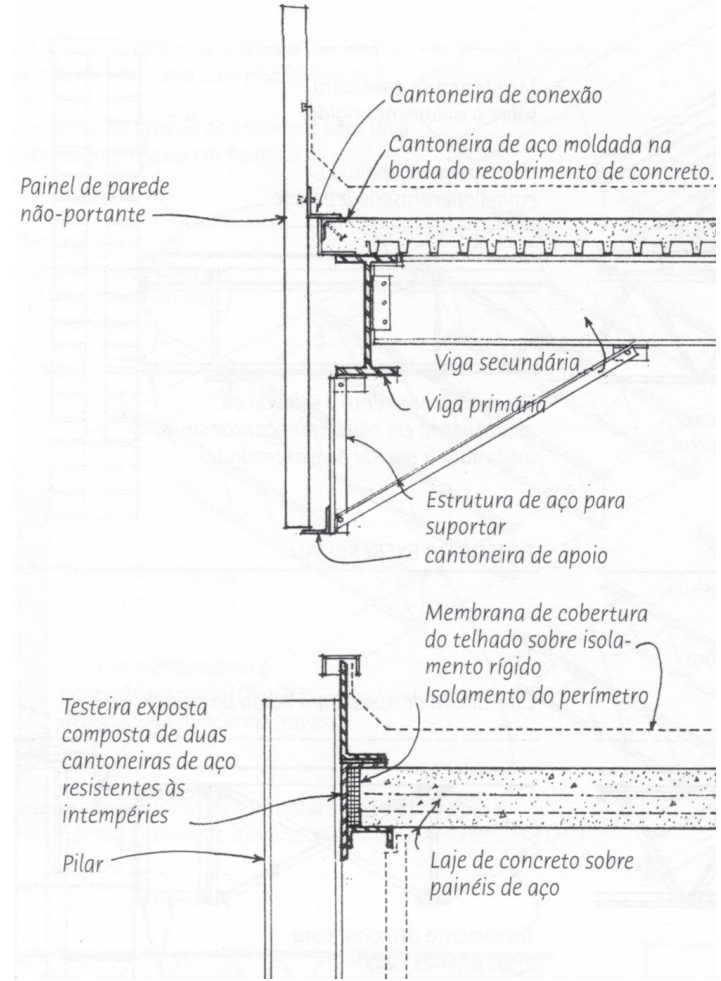



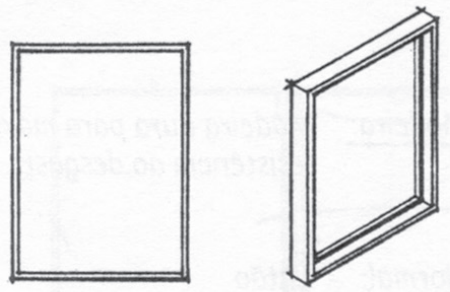

FIXA
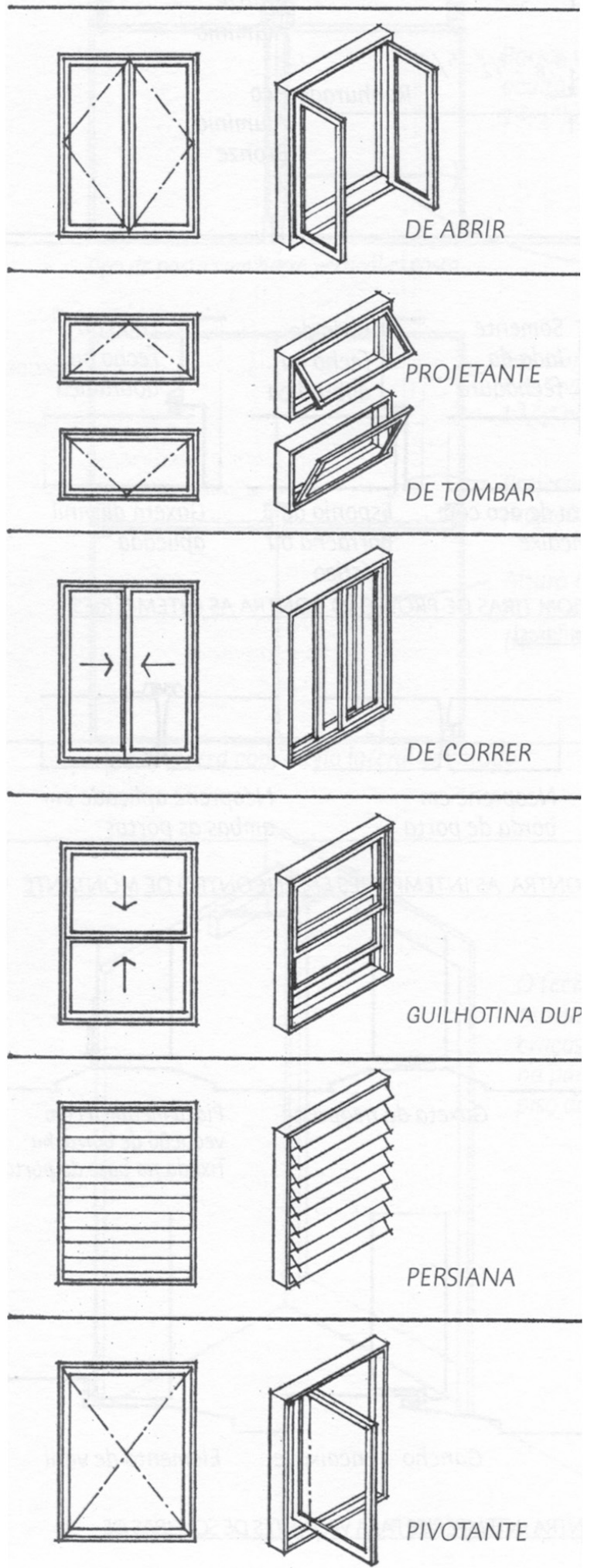

PIVOTANTE
O Arquitetura: forma, espaço

e ordem não trata do desenho em si. Decidimos que, mesmo assim, se incluísse entre os outros quatro, pois é através do desenho que explica seu conteúdo, que é caracterizado principalmente na leitura e proposição dos espaços da arquitetura. Aprendemos com este livro, por meio de desenho - desde o ponto, a linha e o plano -, a ler e compreender a forma, o volume, o espaço, aberturas, delimitações, a luz, organização da forma e do espaço, acessos, configurações de vias, espaços de circulação, proporção e escala, a escala humana, eixo, simetria, hierarquia, repetição etc.

Em todos eles, há um cuidado com a diagramação visual, tipo de letra, composição na folha etc., que não vimos nos livros de Oberg e de Gildo Montenegro. Tratando-se de livros de arquitetura e desenho e considerando-se a importância do desenho como meio de comunicação, estes livros apresentam o seu conteúdo de forma agradável e de fácil consulta. Mas, o que mais chama a atenção e é o diferencial destas publicações, é a precisão do grafismo das incontáveis ilustrações do autor, à mão livre ou com
Fig.[4] 67

Tipos de janelas por operação, p.7.22.

Há equívocos nas representações (linhas de traço e ponto) sobre o modo de abrir destas janelas. Ressalvas à parte, estes desenhos são didáticos para exemplificar tipos de janelas e seus modos de abrir. 
instrumentos, nada no computador.

Muitos desenhos de um livro se repetem em outros subseqüentes. Acreditamos que se utilizam de uma estratégia de marketing comercial. Apostando na boa repercussão no Brasil, a editora Martins Fontes lançou, em português, o Arquitetura: forma, espaço e ordem e o Dicionário Visual de Arquitetura, a preço muito mais acessível que os importados. A editora Bookman traduziu Técnicas de construção ilustradas. Ainda há Representação gráfica para desenho e projeto, na versão portuguesa. Temos a impressão do gradativo aumento da preferência, tanto alunos como entre professores, em adquirir estes em vez dos manuais nacionais (Oberg e Montenegro) ainda reeditados. As editoras, salvo exceção, não se enganam ao empreenderem estas traduções e reedições brasileiras. É o que foi confirmado nas respostas do questionário.

Todos os livros de Ching foram considerados por nós como bons manuais, que ensinam o desenho arquitetônico ou desenho de arquitetura em geral. Todos os desenhos são exemplares e de qualidade tal que nos inspiram a imitá-los. 0 que mais se aproxima do objeto de nossa pesquisa, neste capítulo, e que recomendaríamos aos alunos, é o Manual de dibujo arquitectónico, embora também não represente, totalmente, as questões da materialidade e da construtibilidade. Mas, diferentemente de Oberg e Montenegro, assinala estas preocupações quando desenhadas em escalas maiores. Também não trata da cotagem em nenhum dos livros, o que consideramos um ponto negativo. Não temos dúvida de que, se o autor abordasse este tema da cotagem - que é importante -, poderia fazê-lo com competência, como todos os outros assuntos, e proporcionaria uma grande contribuição ao ensino de desenho. A somatória destes livros, incluindo-se o de técnicas de construção, acaba formando o repertório pretendido e necessário para a compreensão total do desenho arquitetônico: representação, materialidade e construtibilidade. Além disso, mune-nos dos saberes necessários ao auxílio de projeto e leitura deste, por meio da representação gráfica.

A nosso ver, o ensino de desenho técnico arquitetônico, além de contemplar as questões relativas ao grafismo, ao sistema de representação ortogonal - plantas, cortes, vistas -, axonometrias e perspectivas, deve enfatizar dois aspectos: o registro ou indicação clara da materialidade e construtibilidade do que o aprendiz está representando, já que se pretende ser uma representação do edifício (e não somente o desenho pelo desenho em si); e o de ver e aplicar o desenho como comunicação, como linguagem, desde as preocupações com a diagramação, exposição clara dos textos, especificações até o endereçamento 
entre os desenhos etc. Esses desenhos tratam, em última instância, da vontade de viabilizar em obra construída. Neste sentido, os desenhos técnicos dos arquitetos servem de suporte para outros profissionais aplicarem seus conhecimentos. A desejável integração entre desenho, projeto e tecnologia se dá através da correta representação gráfica de arquitetura. Caso contrário, que espécie de arquitetos estaríamos formando, se saíssem para o mercado com possíveis falhas na área de tecnologia e desenho?

Sendo assim, é oportuna esta notação do arquiteto Louis Khan, em que a arquitetura compreende, em sua totalidade, mais que a criação e apreensão dos espaços:

A única maneira que se tem de construir, a única maneira pela qual se pode dar origem ao edifício é através do mensurável. É preciso obedecer às leis da natureza e empregar tijolos, métodos de construção e de engenharia. No final, porém, quando o edifício torna-se parte da vida, ele evoca qualidades não mensuráveis, e o espírito de sua existência passa a predominar (Louis Kahn in CHING, F. D. K. Dicionário Visual de Arquitetura, p.8).

\section{Norma ABNT NBR 6492 Representação de projetos de arquitetura}

Na página eletrônica da ABNT - Associação Brasileira de Normas Técnicas - pesquisamos que normalização é "atividade que estabelece, em relação a problemas existentes ou potenciais, prescrições destinadas à utilização comum e repetitiva com vistas à obtenção do grau ótimo de ordem em um dado contexto. Dois dos objetivos da normalização são proporcionar meios mais eficientes na troca de informação entre o fabricante e o cliente, melhorando a confiabilidade das relações comerciais e de serviços; e evitar a existência de regulamentos conflitantes sobre produtos e serviços em diferentes países, facilitando assim o intercâmbio comercial. ${ }^{7}$

Em nossa pesquisa, levantamos as seguintes normas relacionadas ao desenho
${ }^{7}$ http://www.abnt. org.br/normal_oque. htm, acessado em 02/07/2003. 
técnico NBR 8402, Mar/1994, Execução de caracter para escrita em desenho técnico; NBR 10647, Abr/1989, Desenho técnico; NBR 10067, Mai/1995, Princípios gerais de representação em desenho técnico - vistas e cortes; NBR 10582, Dez/1988, Conteúdo da folha para desenho técnico; NBR 13272, Fev/1995, Elaboração da lista de itens em desenho técnico; NBR 13278, Fev/1995, Referência a itens em desenho técnico; NBR 8196, Dez/1999, Emprego de escalas em desenho técnico; NBR 10126, Nov/1987, Cotagem em desenho técnico; NBR 8403, Mar/1984, Aplicação de linhas em desenhos - tipos e largura das linhas; NBR 10582, Dez/1988, Apresentação da folha para desenho técnico; NBR 10068, Out/1987, Folha de desenho - layout e dimensões; NBR 6492, Abr/1994, Representação de projetos de arquitetura. Esta última é a que analisamos, pois está diretamente relacionada com o objeto da nossa pesquisa.

${ }^{8}$ Enviamos uma mensagem eletrônica à ABNT e nos respoderam que esta norma está em vigor, sem atualização (Rafael

Sorrija, endereço eletrônico: dre5@abnt. org.br), 11.10.2002.
Esta norma - de abril/1994 e desde então, não sofreu atualização ${ }^{8}$ - fixa as condições exigíveis para representação gráfica de projetos de arquitetura, visando à sua boa compreensão. Possui 27 páginas e define os diversos desenhos de arquitetura - plantas, corte, elevações - e elementos complementares: escala, programa de necessidades, memorial descritivo, especificações, lista de materiais, orçamento. Descreve os tipos de papel, formatos, carimbo ou quadro, dobramento e reprodução dos documentos de desenho (fotocópia, heliografia etc). Discrimina as fases de um projeto arquitetônico - estudo preliminar, anteprojeto e projeto executivo - e o que cada uma delas deve conter.

Na seção de Anexos desta norma, discrimina a representação gráfica dos desenhos de arquitetura: tipos de linha, caligrafia, escala, indicadores (norte, de chamadas, de acessos, sentido das escadas e rampas, inclinação de telhados e inclinação de rampas e pisos), cotagem e cotas de nível, eixos, marcação de cortes e de detalhes em planta, numeração e títulos dos desenhos, designação de portas, esquadrias e referências de acabamento. Traz, ainda, um quadro geral de acabamento, de área e de esquadrias, além da representação de texturas de alguns materiais.

As explicações de cotas abrangem os aspectos da sua correta representação, mas não explicam os procedimentos básicos da cotagem, cotas parciais e totais, casos particulares, cotas funcionais etc. Não foi feita referência a qualquer norma complementar, nem tampouco à norma NBR 10126 - Cotagem em desenho técnico, embora o procedimento de cotagem, quanto à forma, em desenho arquitetônico, seja um pouco diferente do de desenho técnico. Talvez, falte uma norma específica para cotagem em desenho arquitetônico. 
No item A-10 (p.17), sobre cotas de nível, a interpretação correta de sua aplicação deixou-nos uma dúvida, quanto ao nível acabado e nível em osso. A norma apresenta os dois níveis com o mesmo valor de cota. Não deveria fazê-lo com valores distintos, cuja diferença seria a espessura do piso acabado $(5$ ou $6 \mathrm{~cm})$ ?

A-10.3.1 Desenho a grafite, conforme exemplos:

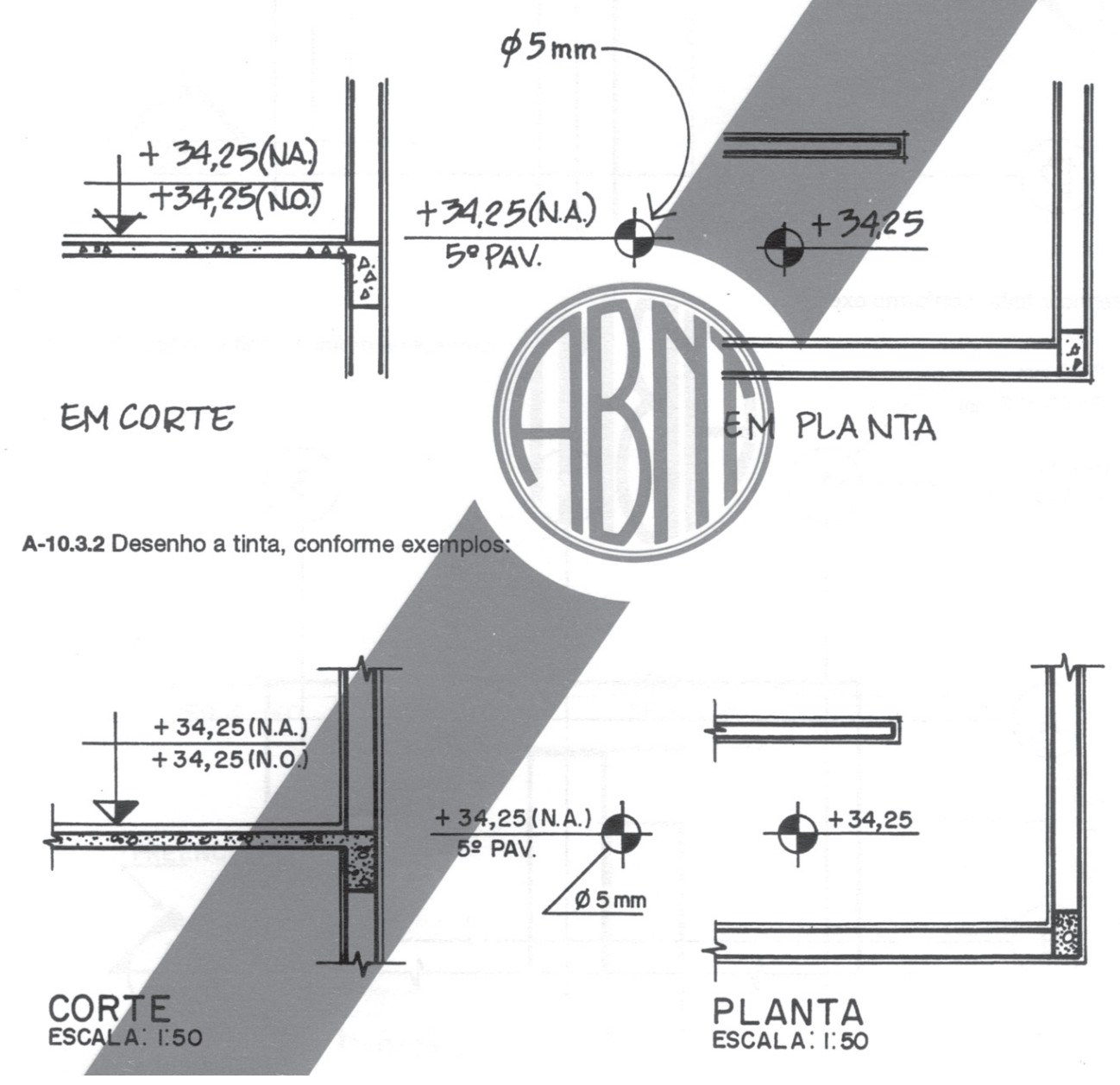

Optou-se por um modo de representar o desenho a lápis e, logo em seguida, sua representação a nanquim e rotulado a normógrafo, indicando as réguas de escrita adequadas (régua 60, 80, 100 etc.). À primeira vista isso parece redundante, mas, como normatização e modelo a seguir, parece ser o melhor modo de exemplificar.

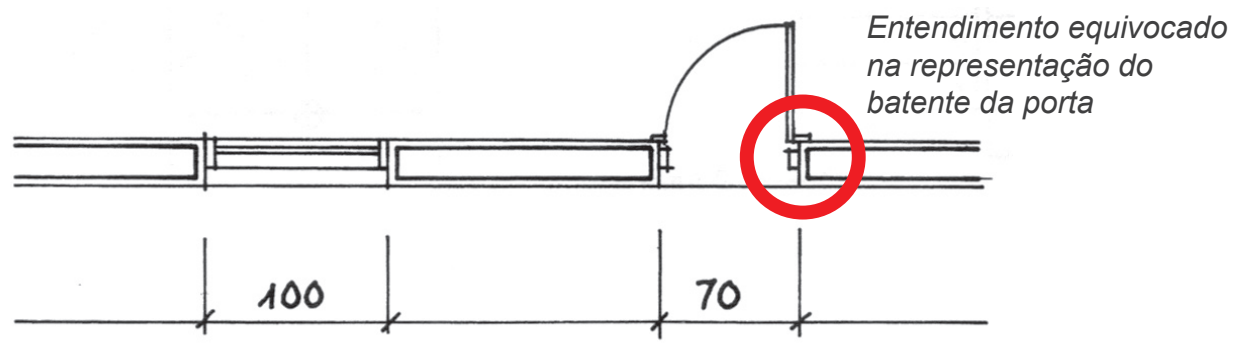

Fig.[4] 68

Indicação de cotas de nível, item A-10.3, NBR 6492, p.17.
Fig.[4] 68

Cotas de vãos de portas e janelas, item A-9.2, NBR 6492, p.16. 


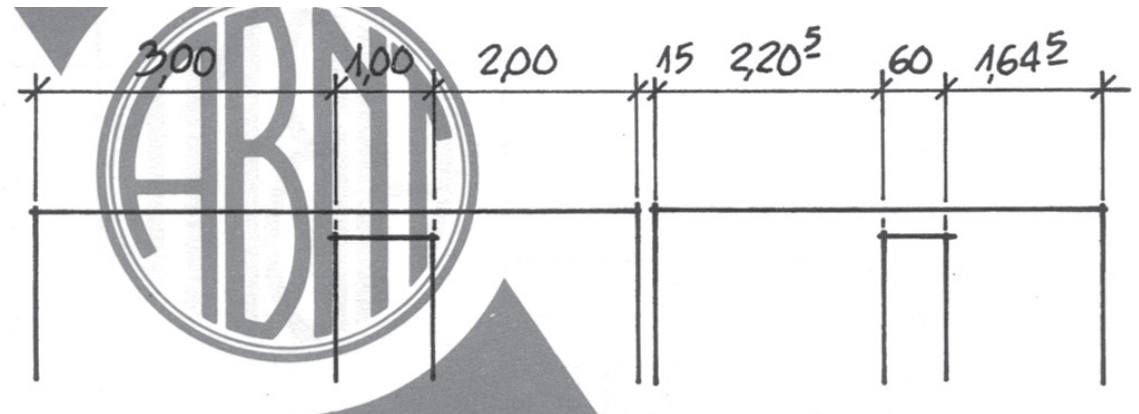

A-9.1.2 Desenho a tinta, conforme exemplo:

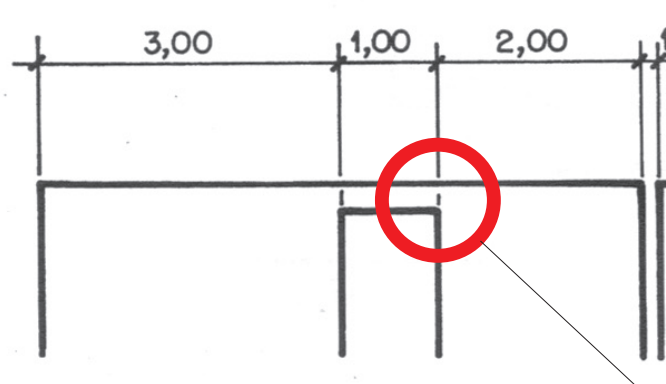

Fig.[4] 69

Cotas, NBR 6492, item A-9-1, p.16.

Fig.[4] 70 Cotas, NBR 10126 , fig. 10, p.4.

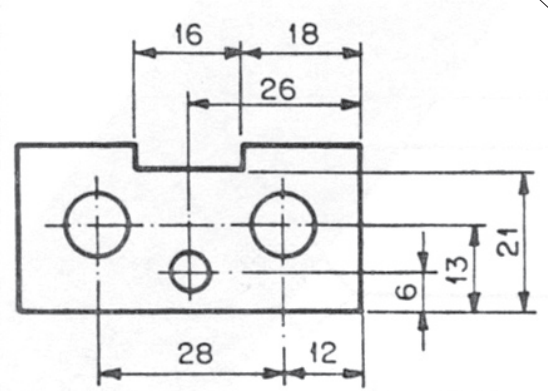

As linhas auxiliares de cota não devem ser interrompidas ao cruzar o contorno do desenho. 0 modo correto está na figura seguinte, da norma NBR 10126/1987 - Cotagem em desenho técnico.

A essência da normatização sobre a representação de projetos de arquitetura está toda registrada. Os professores de desenho e de projeto devem conscientizar seus alunos da existência desta norma, pois ela complementa o conteúdo dos manuais de desenho arquitetônico. A nosso ver, a norma deve, agora, contemplar as novas possibilidades de desenho pelos sistemas CAD e, neste sentido, encontra-se desatualizada. Exemplo disso são os desenhos em nanquim, o que, atualmente não faria sentido, nem as réguas de escrita 60,80 etc., cujos códigos os novos alunos desconhecem. A passagem do anteprojeto para o projeto executivo, em $C A D$, é muito rápida; parece ser apenas uma questão de etapa a cumprir e a apresentar ao cliente. No entanto, quanto à forma dos desenhos, já se constitui, praticamente, num desenho executivo, que, evidentemente, receberá mais informações de cotas, especificações, detalhes etc. Entre os novos saberes que o CAD traz consigo, acreditamos que os "layers", camadas ou níveis de desenho, é que devem ser exaustivamente estudados no sentido de sua normatização. Na ausência de uma norma deste 

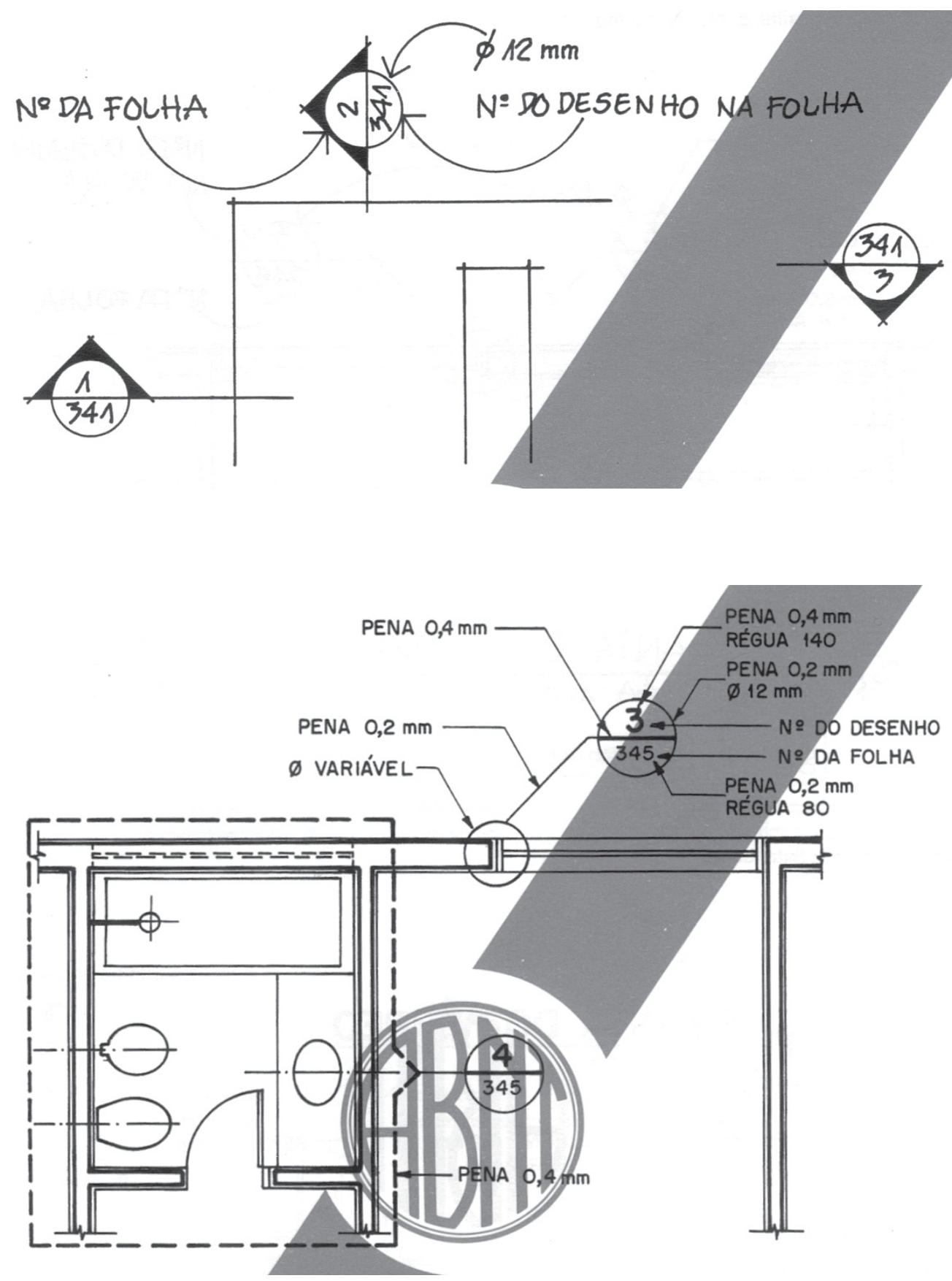

tipo, uma equipe de profissionais, como já citamos no primeiro capítulo, coordenada pela ASBEA - Associação Brasileira de Escritórios de Arquitetura, elaborou um documento que normatiza, entre outras coisas, a nominação e uso destes "layers", com o fim de facilitar a comunicação entre os profissionais, nas áreas de arquitetura, engenharia e construção civil.

\section{Fig.[4] 71}

Marcação dos cortes gerais, NBR 6492, p.19.

Há um equívoco (e gera confusão), entre estes dois desenhos, quanto à notação de "número da folha" e "número do desenho": alternam-se dentro da bola ...

Fig.[4] 72

Marcação de detalhes, NBR 6492, p.21. 


\section{Considerasões finais}

É lamentável, mas, atualmente, nas escolas de arquitetura, em especial nas particulares, está sendo cada mais reduzido o número de horas-aula dedicados a estas disciplinas e, também, ao curso como um todo. A grande proliferação de escolas de arquitetura está causando um efeito negativo na medida em que há um grande interesse em tornar estes cursos mais rentáveis. É diminuindo a carga horária que conseguem este objetivo. $O$ resultado é facilmente previsível: Arquitetos cada vez pior preparados para enfrentar o mercado de trabalho!

G.L.S., 2002

As queixas dos professores de que os alunos não sabem representar e, na mesma direção, também dos arquitetos quanto a seus estagiários ou colegas recémformados é procedente. Também constatamos este fato, como professores, nos atendimentos de projetos finais de alunos do último ano, cujos desenhos carecem, muitas vezes, de expressividade ou denotam imaturidade na concepção estrutural e conhecimento técnico-material.

Estudado no primeiro capítulo, o desenho arquitetônico, constituindo-se num autêntico sistema gráfico, é o melhor meio para passar da idéia arquitetônica 
à sua realização. Existem duas instâncias, apontadas por ORTEGA (2002, p.32), em etapas diferentes, do desenho de arquitetura que tem a função de linguagem: a de concepção (criação) e a de viabilização (a comunicação dessa criação). E, em geral, não se cria e se constrói um edifício, com certo grau de complexidade, sem uma representação prévia mais ou menos esquemática, ou seja, sem um projeto. O desenho, com suas várias finalidades e atributos, em seus diversos tempos ou fases de um projeto para diferentes destinatários, constitui o meio mais eficaz do desenvolvimento do pensamento, criação, registro e viabilização arquitetônica.

O questionário nos mostra que, para a maioria dos professores participantes, o desenho arquitetônico é importante. Então, unimo-nos às vozes desta maioria, certos de que temos um ponto em comum na construção desta reflexão, querendo detectar falhas, ouvir outros, almejar soluções. Linguagem básica do arquiteto, as plantas, cortes e vistas se fazem presentes em todas as fases do processo de criação, apresentação e produção da arquitetura; constituem suporte para outros profissionais se debruçarem e complementarem com suas especificidades (instalações, estrutura etc.). Entretanto, parece estar havendo, no ensino, um certo descaso, desprezo de algo tão básico e simples e que, no entanto, é vital, indispensável para viabilizar um projeto de arquitetura.

Faz-nos pensar que, sendo aparentemente fácil e simples - e, na verdade, é simples mesmo - os alunos devem aprender sozinhos, já que é derivação das projeções ortogonais, da Geometria Descritiva, que seria responsabilidade do Ensino Médio (somente as escolas técnicas têm cumprido esta exigência) e de um punhado de convenções e simbologias (código). Ou, o que não soa bem, o pensamento de muitos, correto em termos, de que cabe ao arquiteto projetar, e nem tanto desenhar; e que desenho técnico se aprende em seis meses num escritório de arquitetura. Parece ser aí, neste descuido e indiferentismo em ir às raízes do problema, que detectamos uma "pane", diagnosticada em queixas, desorientações e sofrimentos dos alunos, cobrança sem terem culpa, desenho "sem desenho", desenho imaturo, vacilante, inexpressivo e não-comunicativo.

O conceito das projeções ortogonais é facilmente transmitido e assimilado pelos alunos. Mas, ao aplicá-lo a desenhos de arquitetura, estão em jogo outras implicações. As projeções são um meio; o fim é a representação da arquitetura, seus espaços, sua materialidade, relações volumétricas, visões, proporções etc. Alguns alunos, distraidamente, erram nas diferenciações entre elementos em corte e em vista, o que pode ser facilmente sanado com alguns minutos de explicação. Porém, reparamos que o aluno peca, 
na maioria das vezes, na materialidade: na diferenciação, por exemplo, de lajes, vigas, baldrames, alvenarias, fechamentos etc. nos desenhos de um corte. Parece, muitas vezes, que desenham uma linha pela linha em si - ou as linhas não se encontram nos cantos - e não como representação de algo material, real, construído ou a ser construído. Seus desenhos carecem também de expressividade, texturas, hachuras, densidade, relação fundofigura, composição na folha, distribuição dos desenhos etc. Estes últimos se referem à forma de apresentação e de encarar o desenho como instrumento de comunicação. E, por este viés, o da comunicação, muitos alunos não gerenciam perfeitamente as simbologias, chamadas de detalhes e em que folhas estarão endereçadas, tabelas, especificações, cotas (mesmo básicas) mal posicionadas ou até mesmo erradas etc.

Mas, haverá quem diga que, na escola, os alunos geralmente não apresentarão mais que um Estudo Preliminar nas disciplinas de Projeto e, muitas vezes, seus desenhos estarão na escala 1:100 ou menor, o que inviabilizaria a representação diferenciada, nos cortes, de lajes, vigas etc. Ora, se nós professores não lhes ensinamos isto na escola de arquitetura, onde, então, aprenderão? Não parecem ser estes aspectos da materialidade também pertinentes e próprios ao ensino de desenho técnico arquitetônico?

O desenho técnico arquitetônico é elaborado, preliminarmente, com linhas, as quais, no seu conjunto, gradativa e intencionalmente colocadas, vão dando forma, na busca da representação das intenções do autor, arquiteto ou desenhista. Existem, a nosso ver, três graduações da força do traço, com instrumentos. A primeira é a linha fina e fraca (não quer dizer vacilante), que desempenha a importante função de linha auxiliar, quase "invisível", que estrutura o desenho (muitos não se utilizam dela: que pena!). A seguir, a linha fina, porém firme, forte (não grossa), que vem definindo o desenho geral. Quanto a este "forte", que não deve ser pesado nem grosso, o autor costuma ilustrar aos alunos, em tom de brincadeira, através de uma comparação: ao fechar a porta de um carro (destes que quase nunca fecham direito à primeira tentativa), "não com força (como se fosse "fechar para sempre" ou que nos sugere a pergunta imediata se tal pessoa não tem geladeira em casa), mas com firmeza, precisão, com técnica”. Esta categoria de linha desenha as portas, os pisos e solerias, as janelas e parapeitos, os mobiliários fixos ou móveis ..., enfim, tudo. Ela aparece, já é o desenho em si, e faz desaparecer a linha auxiliar que serviu de guia (estas nem precisam ser apagadas, pois "somem" ao cumprir sua missão), que possibilitou esta atuação tão notada e brilhante, de "personalidade" desta que aparece e fica. A terceira linha, por fim, é que proporcionará a diferenciação do que está em corte e do que se apresenta em 
vista. É grossa (espessa, não grosseira) e salta aos olhos. Às vezes, um pouco mais fina, mas preenchida com uma hachura por dentro do que ela delineia. São as paredes seccionadas em planta e em corte. Num desenho mais completo, final (que vai para a obra), na escala adequada, é a alvenaria-osso, então, com linhas espessas para diferenciar-se do seu revestimento, de linhas finas.

Parece ser assim que adquirimos o gosto pelo desenho técnico arquitetônico, após alguns meses de prática, "com o grafite de dureza correta sobre o papel correto", e podemos seguir adiante. Acreditamos que alguns alunos não praticam (ou não tiveram a oportunidade de aprender assim) o suficiente para chegar a este estágio de "domínio" da lapiseira, da régua $T$ e de esquadros sobre o papel. Os que alcançam esta posição, além de criar gosto por isto, alegam até que é uma terapia, um "descanso", perto de outras atividades do arquiteto. Chegam a desenvolver seu próprio estilo, jeito etc. Do contrário, o desenho apresenta-se "insosso", sem expressividade, com linhas titubeantes e sem comunicar, com eficácia, as intenções do projeto.

Um desenho técnico de arquitetura tem de ser eficaz, preciso, até "frio", mas pode, também, ser bonito, expressivo, atrativo ao olhar, ser informativo e comunicativo de uma maneira agradável, "confortável" à consulta. Entram aí a expressividade, os diferentes pesos de grafismo, texturas, cores, densidade, diagramação etc.

No entanto, também pode ser o fato de o aluno ainda não saber o que quer representar (o projeto ainda não está definido) ou como representar (Como represento uma viga baldrame? E esta estrutura do telhado? Estes fechamentos? Ou até, antes: Como funciona o esquema estrutural do meu projeto?). Como desenhar bem, com segurança, se não sabe bem ainda o que desenhar (dúvida de projeto) ou o que deve desenhar e como desenhar ou representar (dúvidas de desenho, de representação)? Não é verdade que um apresentador somente irá falar bem, discorrer sobre um assunto com boa desenvoltura, se dominar bem (ou quase) o assunto? Portanto, Desenho, Tecnologia e Projeto devem estar mais integrados, na medida das possibilidades, e adaptados ao modo de ensino de cada escola.

O completo entendimento de alvenaria e laje-osso e seus revestimentos nos possibilita desenhá-los diferenciadamente, a partir da escala 1:50. É um grau de representação mais próprio de desenhos executivos finais, que se dirigem à obra. Embora não possamos comprovar, há evidências de que este rigorismo não é prática geral nas escolas. Assim, os professores devem, pelo menos, comentá-los e ilustrar com exemplos. 
${ }^{1}$ Cotar é uma questão de bom senso: citação do arquiteto José Mário Nogueira de Carvalho Jr., entrevistado pelo autor, dia 10.01.2003. No contexto da entrevista e vendo um desenho executivo exemplar de uma planta elaborada em seu escritório,

sabemos que ele não cita isso deliberada e descuidadamente, mas, embasada em muitos anos de prática profissional.
Muitas vezes - aproveitando esta discussão -, os alunos do último ano não chegam aos desenhos de alguns detalhes importantes de seu projeto, porque podem nunca ter visto um projeto executivo completo. Uma exposição desses documentos de desenho com explicações de como se apresentam e como se dá a comunicação entre eles (chamadas de detalhes e em que folha estarão) deve fazer parte do repertório gráfico dos alunos, mesmo supondo que nunca chegarão a esta etapa (de projeto executivo) em seus trabalhos acadêmicos de projeto. Perceberão, então, as escalas em que foram desenhados os detalhes, um grau mais apurado de informações neles contidas (textos e cotas), texturas, os códigos (simbologias) aplicados aí etc. Devemos ainda explicar-lhes que são os documentos que, efetivamente, garantirão a perfeita execução da obra. E que devem ser precisos, resolvidos, eficazes na comunicação aos profissionais que irão consultá-los, que são engenheiros, empreiteiros, fornecedores, profissionais dotados do conhecimento da linguagem (códigos) específica deste nível de complexidade que já se distancia (há exceções) do conhecimento do cliente leigo.

Em matéria de cotagem, podemos levantar algumas discussões. Uma delas é de que, os alunos, em geral, não passarão do estudo preliminar em seus projetos escolares; logo, não vão cotar tanto. Conseqüentemente, pode acontecer que os professores acabem não thes ensinando as cotas, senão através de mínimas explicações básicas. Outra, é de que aprenderão, fatalmente, na vida profissional. Por fim, que "cotar é uma questão de bom senso" (CARVALHO JR.) ${ }^{1}$ e não é necessário alocar tanto tempo para ensinar isto.

Os números do questionário registram, para nossa surpresa, estatísticas positivas e favoráveis ao aprendizado do aluno no que se refere ao ensino de cotas, que julgamos importante. Justamente o que levou-nos a concentrar algumas questões, até demasiadas, sobre a cotagem, foi o fato de constatarmos como os alunos (e muitos dos estagiários que auxiliavam o autor nos trabalhos profissionais) e os recém-formados, em sua grande maioria, cotam mal, e como os manuais ensinam este assunto de maneira superficial. Os próprios alunos o consideram tarefa árdua, chata, "elefante branco". Paralelamente a esta pesquisa, como docente, elaboramos e ministramos, em 2002, uma aula para alunos de Desenho Arquitetônico do primeiro ano, lançando, ao final, um exercício: cotar uma planta de um projeto de uma residência. Obtivemos alguns resultados bons (na ordem de 15\%) e a maioria errou em questões básicas fortemente comentadas na aula expositiva. É claro que podem estar em jogo distrações, falta de atenção etc. No entanto, é mesmo tarefa árdua, 
que requer muita atenção; o assunto merece, pelo menos, explicações básicas a serem transmitidas aos alunos e muita prática para então chegar à posição de que trata-se de uma questão de bom senso.

É verdade que, na escola, o ensino das cotas não se faz tão importante perto de tantos outros assuntos a serem transmitidos aos alunos, ainda mais sabendo-se que aprenderão, imediatamente, na vida profissional. Mas, o mínimo deve ser dito, minimizando as surpresas "lá na frente", no primeiro trabalho profissional do recém-formado, em que o projeto reivindicará, dura e rigorosamente, ausência de erros de medidas, de equívocos, não somente de cotas, mas também de especificações. Afinal, o ensino da arquitetura está ou não voltado para a qualidade dos projetos de seus ex-alunos, em sua totalidade? Neste sentido, causam estranheza os resultados positivos, e valeria à pena passá-los por uma comprovação mais precisa.

Chegar ao nível do detalhe executivo requer do aluno uma outra grandeza de atenção, diferente das requeridas nas plantas, cortes e vistas (muitas vezes em escala 1:200 ou menor) convencionais. Chega-se ao "parafuso" - um projeto executivo vai além da escala 1:50 -, tamanho real, comercial, de catálogo. Entra em campo o interesse pela funcionalidade de uma peça e de todo o seu conjunto, o entendimento real de como a estrutura do edifício está funcionando, dos acessórios de fixação etc. Passar por isto, com sucesso, é quase chegar à maturidade de todo este processo, que pressupõe a desejável integração da tríade projeto-técnica-desenho.

São, também, estas questões, do interesse dos alunos, de pesquisarem por conta, de buscarem resolver, tecnicamente e através do desenho, os detalhes de suas propostas arquitetônicas etc. Os bons alunos assim o fazem e se despontam acima da média, sempre.

Geralmente, ensina-se o desenho arquitetônico no primeiro ano. Estas complexidades de desenho e de obra formam um conjunto tal de informações que se torna impossível a esses alunos, recém-chegados ao curso, assimilaremno completamente. Se não o ministramos bem, mostram-se desinteressados, desmotivados. Uma disciplina optativa, em algum outro ano, que ensinasse desenho executivo de arquitetura, é uma idéia interessante e estratégica, pois os alunos, sentindo a necessidade de recuperar ou revisar estas demandas, a encarariam com mais atenção e proveito.

Essas dificuldades, de transmitir bem os ensinamentos do desenho arquitetônico 
ou da não-assimilação completa por parte dos alunos, são reais. Às vezes, o professor nem é da área de desenho especificamente. Detectamos algumas incongruências nos números otimistas de algumas respostas - como as já citadas (cotagem, perguntas específicas de projeto executivo) - do questionário quanto ao ensino desta matéria, em contraposição aos muitos alunos e recém-formados que não desenham bem. Nossa justificativa para isto é que pode haver alguns professores que não querem admitir suas falhas, que pressupõem esforços denodados de mudanças, muitas vezes substanciais. 0 autor mesmo - que é também professor nesta área -, num processo reflexivo ao longo desta pesquisa, reconhece algumas posições a serem questionadas e revisadas. Possivelmente, esta situação é própria deste instrumento de pesquisa (questionário), que acaba por conduzir o respondente à cautela excessiva e ao auto-policiamento.

Os manuais nacionais de desenho arquitetônico analisados - dos autores Oberg e Montenegro - seguem e refletem a linha dessas deficiências. Como literatura de apoio, poderiam proporcionar uma contribuição maior, porém isto não acontece. Detectamos falhas na própria apresentação do tema do desenho, na carência de tratar com cuidado o tema do traço, da linha, elemento primeiro na constituição do desenho técnico. Além disso, esses manuais abordam somente a representação do objeto arquitetônico em si, mas não a "materialidade" dos materiais de construção ou a exposição do sistema estrutural. Estas questões são apresentadas separadamente (às vezes detalhes desnecessários, hoje, como os desenhos exaustivos das partes componentes de uma porta) e não há vínculo com o desenho de plantas e cortes. As cotas são fracamente ensinadas, e os elementos constitutivos da "boa comunicação" entre os desenhos, as simbologias etc. são transmitidos de modo irrelevante e superficial. Apresentam, também, questões desatualizadas, como escadas de incêndio não condizentes com as atuais normas do Corpo de Bombeiros. Os dois manuais devem passar por revisão e atualização substanciais para retomarem a preferência quando das primeiras edições.

Neste sentido, os manuais de Francis D. K. Ching superam os de Oberg e Montenegro. Apresentam, também, algumas deficiências, que não chegam a comprometer, pois trata-se de materiais de construção ou sistemas construtivos que não se aplicam no Brasil. Também não ensinam cotagem, mas a somatória dos seus manuais/livros, com desenhos exemplares, muito bem diagramados e eficazes em comunicar, apresenta, sem dúvida, a totalidade do que consideramos um bom modelo de manual. Os números do questionário confirmam esta constatação, pois metade dos professores adota esses manuais 
e as livrarias têm vendido mais estes que os dois nacionais.

Nos momentos finais desta pesquisa, chegou até nós - via contato com a editora Ao Livro Técnico - uma nova publicação sobre desenho arquitetônico, de uma autora carioca². Não foi possível analisá-lo, mas, de antemão, numa passagem rápida, podemos afirmar que apresenta muitos pontos positivos em relação aos de Oberg e Montenegro. Ainda não temos como avaliar a sua aceitação entre professores e alunos.

No entanto, os problemas do "não-desenho" são mais estruturais do que pensamos. Geraldo Vespaziano PUNTONI (1997), em sua tese de doutorado já detectara, com profundidade, os sintomas que expusemos, resumidamente, no segundo capítulo. Coincidem com o nosso diagnóstico que, sabendo que o desenho arquitetônico é matéria importante, não somos, enquanto docentes, profundamente conseqüentes ao ensiná-lo aos alunos.

PUNTONI (1997, p.174-189) defende que o arquiteto, na fragmentação da passagem do projeto à obra, alienando-se da cultura da produção, precisa conhecer geometria euclidiana, geometria descritiva e estar treinado a fazer desenhos, para conceber o objeto da arquitetura. Menciona que o uso da geometria projetiva e do desenho técnico revelou-se o melhor meio para a elaboração dos projetos arquitetônicos e tecnológicos; e o uso das figurações gráficas - sendo o modo peculiar do arquiteto conceber, construir e comunicar o seu objeto da arquitetura - é o único meio que o estudante de arquitetura tem de manifestar o seu ato criador, motivo pelo qual precisa conhecer desenho técnico e estar treinado a fazer desenhos. Também sustenta que os alunos devam conhecer os recursos materiais e meios técnicos disponíveis. No entanto, os programas de ensino dos cursos de arquitetura pressupõem que o aluno já tenha estes conhecimentos citados, o que comprova não ser verdade. Defende e propõe a utilização de outro método operativo para a produção do objeto da arquitetura, que não dependa, logo de início, do conhecimento de desenho técnico; o estudo da geometria euclidiana, geometria descritiva e desenho técnico; a realização sistemática e contínua de treinamentos da habilidade de fazer desenhos; gestões junto às autoridades competentes para a inclusão do estudo destes conhecimentos (geometrias e treinamentos da habilidade de fazer desenhos) nos currículos dos cursos fundamentais, médios e superiores. Compartilhamos estes diagnósticos, que ainda se fazem presentes em muitas escolas, e também as indicações a serem tomadas. Uma vez que o número de horas-aula é cada vez menor para o ensino de desenho nas escolas de arquitetura, a retomada do ensino de geometria euclidiana e de geometria descritiva deve se constituir de exercícios mais práticos, voltados para a área
2 Desenho de

Arquitetura, de Patrícia

Ferreira, lançada em 2001 pela Editora

Ao Livro Técnico.

A autora é arquiteta pela Universidade Fluminense, Mestre em Tecnologia com ênfase em Educação Tecnológica pelo CEFET-RJ e é professora de Desenho Técnico Básico e de Desenho de Arquitetura também no CEFET-RJ. Escreveu, também, em conjunto com a Prof. Maria Teresa Miceli, um livro de desenho técnico básico, pela mesma editora.

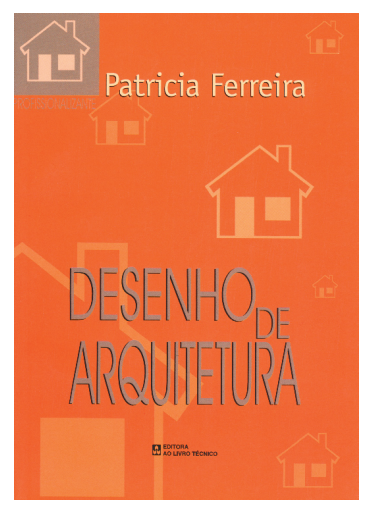

Fig. 73

Capa do livro Desenho de arquitetura. 
de desenho de arquitetura.

A carência de conhecimentos técnicos dos sistemas estruturais, dos materiais de construção e seus desempenhos limita os alunos a apresentar seus desenhos, pois, como já foi citado, não desenhamos o que não conhecemos. Neste sentido, é desejável que haja um esforço integrado entre as disciplinas de desenho, projeto e tecnologia, na busca da diminuição destas carências, ensinando e estimulando os alunos a despertarem o olhar e a atenção para os aspectos da tecnologia construtiva que, longe de limitar sua criação, poderá levá-los a irem mais longe, com os pés no chão, seguros da viabilidade de seus projetos. Arquitetos como Dubugras (1868-1933), Rino Levi (1901-1965), Artigas (1915-1985), Oswaldo Bratke (1907-1997), João Filgueiras Lima (o Lelé, n. em 1932) e muitos outros constituem exemplos deste correto procedimento de inventar e produzir arquitetura, através do desenho e conhecimentos técnicos. Assim, acreditamos que o professor de desenho, como defende Yves DEFORGE (1981, p. 236), deva considerar-se "essencialmente encarregado do curso da construção". Além de ensinar a representação do objeto da arquitetura por meio da geometria projetiva, deve, de forma indispensavel, transmitir aos alunos a necessidade do comparecimento da representação dos diferentes materiais e dos sistemas estruturais do edifício desenhado. A ausência dessas preocupações denotaria um ensinamento superficial, inconsistente e até enganoso.

É necessário, também, a alocação de mais horas-aula para o ensino de desenho que, além de resgatar (em muitos cursos, dos quais o da escola de São (arlos) o ensino de geometria descritiva, possam, com mais profundidade e estratégia, propiciar a transmissão, aos alunos, do desenho técnico, desenho arquitetônico, axonometrias, perspectivas cônicas, desenho livreexpressivo, enfim, do desenho como fundamental instrumento de linguagem do arquiteto.

Estas questões devem ocupar uma posição de destaque em nossas preocupações acadêmicas, na busca da qualidade da formação do profissional arquiteto, na área de desenho arquitetônico, que se apresenta como o meio mais idôneo para a criação e viabilização do objeto da arquitetura, já que entendemos que o arquiteto é essencialmente um construtor. 


\section{Referências}

ALMEIDA, M. S. de. (1984). O desenho do arquiteto. Dissertação de Mestrado. São Paulo, FAU/USP.

ANDRADE, C. R. M. (1986). Pelos espaços do ensino. Revista Arquitetura e Urbanismo. São Paulo: Pini, n.5, abr1986, p.54-55.

ASSOCIAÇÃO BRASILEIRA DE NORMAS TÉCNICAS (1994). NBR 6492: Representação de projetos de arquitetura: elaboração. Rio de Janeiro.

ASSOCIAÇÃO BRASILEIRA DE NORMAS TÉCNICAS (1987). NBR 10126: Cotagem em desenho técnico: elaboração. Rio de Janeiro.

BASSO, Admir. Arquiteto e professor no SAP/EESC/USP São Carlos. Conversa em 17.06.2002.

CARVALHO JR., José Mario Nogueira de. Arquiteto e professor. Entrevista, 10.01.2003.

CESAR, R. C.(1987). Tecnologia e arquitetura. Revista AU, abr/mai 1987. São Paulo, PINI.

CHING, F. D. K. (1998). Arquitetura - Forma, Espaço e Ordem. Trad. por Alvamar Helena Lamparelli. São Paulo: Martins Fontes, 2a. tiragem, 1999.

CHING, F. D. K. (1999). Dicionário visual de arquitetura. São Paulo: Martins Fontes. (ISBN 85-336-1001-7)

CHING, F. D. K. (1999) Manual de dibujo arquitectónico. México: Gustavo Gili.

CHING, F. D. K. (1999). Representação Gráfica em Arquitetura. Trad. Por Luiz A. Meirelles Salgado. Porto Alegre: Bookman, 3a. ed.. (ISBN 85-7307-526-0) 
CHING, F. D. K.; JUROSZEK, S. P. (2001). Representação Gráfica para Desenho e Projeto. Trad. por Anamaria Costa Martins, versão portuguesa. Barcelona: Gustavo Gili. ISBN 84-252-1848-9

CHING, F. D. K.; ADAMS, C. (2001). Técnicas de Construção Ilustrada. Trad. por Luiz Augusto M. Salgado. Porto Alegre: Bookman.

CHITHAM, Robert. La arquitectura histórica acotada y dibujada. México, D.F., Gustavo Gili, 1982.

DEFORGE, YVES (1981). Le graphisme technique. Son histore et son enseignement. Paris: Editions du Champ Vallon. Prefácio de Abraham A. Moles.

DOURADO, G. M. (1994). O Croqui e a Paixão. Revista Projeto. São Paulo, n.180, p.49-67, Nov1994.

DWORECKI, S. M. (1984). Ensino e desenho. Dissertação de Mestrado. São Paulo: FAU/USP. (FAU 741.407^D973 en^ e1/2 / FAU PGR 043:74:37^D993 e^ e1/2)

Estude no Mac (2003). Revista Macmania. São Paulo: Bookmakers, n.105, Março 2003.

FERLINI, P. B. (org.) (1981). Associação Brasileira de Normas Técnicas: Normas para desenho Técnico. Porto Alegre: Globo; Rio de Janeiro: FENAME.

FERREIRA, P. (2001). Desenho de arquitetura. Rio de Janeiro: Ao Livro Técnico.

FIALHO, R. N. (2002). O desenho como metodologia de projeto. Escritório Técnico rino Levi. Dissertação de Mestrado. Orientador: Prof. Dr. Rafael A. C. Perrone. São Paulo: FAU/USP.

FICHER, S. (1989). Ensino e profissão - O curso de engenheiro-arquiteto da Escola Politécnica de São Paulo. Tese de doutorado. São Paulo: Departamento de História da Faculdade de Filosofia, Letras e Ciências Humanas, USP.

FRENCH, T. E.; VIERCK, C. J. (1985). Desenho Técnico e tecnologia gráfica. São Paulo: Globo.

GIESECKE, F. E. (2002). Comunicação Gráfica Moderna. Trad. Alexandre Kawano (et al.) Porto Alegre: Bookman.

GOMES, S. H. T. (2002). Arquitetura e representação gráfica: o impacto das novas tecnologias informacionais. Revista Educação Gráfica, n.6, p.33-42, Nov 2002. Bauru: Faculdade de Arquitetura, Artes e Comunicação / Departamento de Artes e Representação Gráfica, Unesp.

REIS FILHO, N. G. (1997). Racionalismo e Proto-modernismo na obra de Victor Dubugras. São Paulo: FBSP. 
KATINSKY, J. R. Ciência e arte no século XV, in SANTILLANA, G. de (1981). O papel da arte no Renascimento científico. Introdução de Julio R. Katinsky. Trad. por Eunice R. Ribeiro Costa e revisão técnica de Sylvia Ficher. São Paulo: FAUUSP.

(1998). Olhar arquitetura. In: ARTIGAS, J. B. V. Caderno dos riscos originais: projeto do edifício da FAU USP na Cidade Universitária. São Paulo, FAU/USP

(1999) Ensinar-aprender: por uma educação criadora. In: Contribuição ao ensino de arquitetura e Urbanismo, p.7-30. Brasília: INEP/MEC.

LAMPUGNANI, V. M. (1983). Dibujos y textos de la arquitetctura del siglo XX. Utopia y realidad. Barcelona: Gustavo Gili.

LA VEGA, M. C. P. L.; RUIZ, F. A. (2002). El ser o no ser del profesor de dibujo en la enseñabza de la ingeniería contemporánea. Revista Educação Gráfica, n.6, p.33-42, Nov 2002. Bauru: Faculdade de Arquitetura, Artes e Comunicação / Departamento de Artes e Representação Gráfica, Unesp.

LIMA, Luiz Gastão de Castro e. Arquiteto e professor aposentado. Entrevista, 20.11.2002.

MASSIRONI, M. (1982). Ver pelo Desenho. São Paulo: Martins Fontes.

MARAGNO, G. V. Abertura de novos cursos de arquitetura e Urbanismo: Uma questão de quantidade ou de qualidade?, in IX CONABEA - CONGRESSO NACIONAL DA ABEA / XVI ENSEA - ENCONTRO NACIONAL SOBRE ENSINO DE ARQUITETURA E URBANISMO. 10 a 13 de novembro de 1999 - UEL - Londrina - PR. Artigo eletrônico extraído do Caderno n.21, na página eletrônica da ABEA (http://www.abea-arq.org.br/).

MARTINEZ, A. C. (1998). Ensayo sobre el Proyecto. Buenos Aires: Klickzowski Publisher, 1998.

MEDEIROS, Givaldo. Arquiteto e professor no SAP/EESC/USP São Carlos. Conversa em 23.04.2003.

MONTENEGRO, G. A. (1978). Desenho arquitetônico. São Paulo: Edgard Blucher. (EESC 720.28 M777 d e.2)

(1997). Desenho arquitetônico. São Paulo: Edgard Blucher. (Biblioteca FAU/Mackenzie)

(2001). Desenho arquitetônico. São Paulo: Edgard Blucher, $4^{\mathrm{a}}$ ed.; 1 a. reimpressão, 2002.

MONZEGLIO, E. (1993). O desenho conta uma história. Revista Sinopses. São Paulo: Edição Especial Memória, p.62-74, 1993.

MUNARI, B. (1968). Design e Comunicação Visual. Lisboa: Edições 70. 
MUSEU LASAR SEGALL. A linguagem do arquiteto: o Croquis. São Paulo: 1984. (EB 707.4 ML.SS986Li)

OBERG, L. (1950). Curso de Desenho Arquitetônico para arquitetos, desenhistas e construtores. Rio de Janeiro: Editora Gertum Carneiro S/A. (Mackenzie 744.424 Ob2e).

(1963). Curso de Desenho Arquitetônico para arquitetos, desenhistas e construtores. Rio de Janeiro: Sedegra Sociedade Editora e Gráfica, 1963. (Mackenzie 744.424 Ob2e).

(1979). Desenho arquitetônico. Rio de Janeiro: Ao Livro Técnico, $22^{\mathrm{a}}$ ed. (EESC 720.28 OL 12d.21)

ed.: 2002.

(1997). Desenho arquitetônico. Rio de Janeiro: Ao Livro Técnico, $34^{a}$

ORTEGA, A. R. (2000). O Projeto e o desenho no olhar do arquiteto. Dissertação de Mestrado. Orientador: Prof. Dr. Geraldo Vespaziano Puntoni. São Paulo: FAU/USP.

PENTH, Wolfgang (1975). La arquitectura expressionista. Barcelona: Gustavo Gili.

PERRONE, R. A. C. (1993). O desenho como signo da arquitetura. Tese de Doutorado. São Paulo: FAU/USP, Vol.1, 2 e 3. (FAU 720.28^P429d v.1,2,3 e1 e2 / FAU PGR 043:72.021.22^P459 v.1,2,3)

PORTO, M. (1985). O arquiteto tem que falar desenho. Revista Módulo, n.87, p.58-61. Rio de Janeiro: set1985.

Proposta de Diretrizes Curriculares Nacionais para o Ensino de Graduação em Arquitetura e Urbanismo (1998). Ministério da Educação / Secretaria da Educação Superior.

PUNTONI, G. V. (1997). O desenho técnico e o ato criador do arquiteto. Tese de Doutorado. São Paulo: FAU/USP. (FAU 720.28^P969d / FAU PGR 043:741^^P984^^e1 e2)

ROBBINS, E. (1997). Why architects draw. London: MIT Press.

RODELA, Paulo Sérgio. Técnico em Edificações. Conversa, por telefone, em 14.07.2003.

SAHM, E. (org.); MARTINS, C. A. F.; VÁSQUEZ y RAMOS, F.; ANELLI, R. L. S. (1985). Os desenhos da arquitetura. São Paulo: Catálogo de exposição.

SCHAAL, Ricardo. Engenheiro eletrônico e professor no STT/EESC/USP. Conversa em 16.09.2002.

SAINZ, (1990). El dibujo de arquitectura. Teoria e História de un Lenguaje Grafico. Madri: Editorial Nerea. 
SAINZ, J. (1994). Desenho e arquitetura. Revista Projeto, n.180, p.79-83. São Paulo: nov1994.

SALES, José Jairo. Engenheiro civil e professor no SET/EESC/USP. Correio eletrônico em 14.07.2003.

SANTILLANA, G. de (1981). O papel da arte no Renascimento científico. Introdução de Julio R. Katinsky. Trad. por Eunice R. Ribeiro Costa e revisão técnica de Sylvia Ficher. São Paulo: FAU USP. (FAU 270 S227p)

SEGAWA, H. (1999). Arquiteturas no Brasil 1900-1990. São Paulo: EDUSP, $2^{\text {a }}$ ed. Editores.

; DOURADO, G. M. (1997). Oswaldo Artur Bratke. São Paulo: Pro-

SILVA, B. F. C. (1999) Projeto arquitetônico: representação gráfica. Dissertação de Mestrado. São Paulo: FAU/USP. (FAU/USP ...)

SCHUNCK, D. (1999). A construção do espaço como método de ensino de Desenho e Plástica 2, in Contribuição ao ensino de arquitetura e Urbanismo, p.52-60. Brasília: INEP/MEC.

SOUZA, A. de (1987). A Enba, antes e depois de 1930, in XAVIER, Alberto (org.). Arquitetura moderna brasileira: depoimento de uma geração. São Paulo: PINI/ABEA/FVA.

SUZUKI, Marcelo. Arquiteto e professor. Entrevista, 03.04.2003.

TURIN, R. N. (1994). Escritos. São Carlos: EESC/USP.

YUBA, Andrea Naguissa. Arquiteta e doutoranda no SAP/EESC/USP. Conversa em 30.06.2003.

XAVIER, Alberto (org.) (1987). Arquitetura moderna brasileira: depoimento de uma geração. São Paulo: PINI/ABEA/FVA. (EESC 720.981^3a^3e1/2).

ZEVI, B. (1994). Saber ver a arquitetura. São Paulo: Martins Fontes. (EESC $720 \mathrm{z} 63)$

ZANETTINI, S. (1980). O Ensino de Projeto na Área de Edificação. São Paulo, FAUUSP. 


\section{Lista das ilustrações}

[1] Desenho de arquitetura

1: Andrea Palladio. Villa Trissino em Meledo: planta e fachada; xilografia. De I quattro libri, 1570. SAINZ, J. (1990). El dibujo de arquitectura. Teoria e História de un Lenguaje Grafico. Madri: Editorial Nerea, p.118.

2: Autor desconhecido, até o ano 820. Monastério de St. Gallen; planta; pluma e tinta preta e vermelha sobre pergaminho; $112 \times 78 \mathrm{~cm}$. Stiftsbibliothek, St. Gallen. SAINZ, J. (1990). El dibujo de arquitectura. Teoria e História de un Lenguaje Grafico. Madri: Editorial Nerea, 78.

3: Autor desconhecido, até o ano 1275. Catedral de Estrasburgo, projeto A; fachada, tinta sobre pergaminho. Musée de l'Oeuvre de Notre-Dame, Estrasburgo. SAINZ, J. (1990). El dibujo de arquitectura. Teoria e História de un Lenguaje Grafico. Madri: Editorial Nerea, 79.

4: Sylvio Emrich Podestá. Edifício-sede da Microcity Computadores, Belo Horizonte.
Revista Projeto, n.180, nov/94, p.58.

5: Marco Antônio Gil Borsói. Residência em Brasília; caneta hidrográfica. Revista Projeto, n.180, nov/94, p.61.

6: Daniel Libeskind. Teatro Msicon Bremem; Bremem, Alemanha, 1995. Revista Projeto, n.208, mai/97, p.69.

7: Cláudio Libeskind. Edifício-sede da Monark, São Paulo, 1988. Revista Projeto, n. 180 , nov/94, p.55.

8: Bischof, Egozcue, Vidal, Bev Arquitectos/ Pastorino, Pozzolo. AMEBPBA Clinic, Buenos Aires, 1999. Revista Summa, n.54, abr-mai/2002, p.51.

9: Rino Levi, Roberto Cerqueira Cesar, Luiz Roberto Carvalho Franco. Casa Castor Delgado Pérez, 1958. Serviço de Biblioteca e Documentação da FAU/ USP. SAHM, E. (org.); MARTINS, C. A. F.; VÁSQUEZ y RAMOS, F.; ANELLI, R. L. S. (1995). Os desenhos da arquitetura. Catálogo de exposição. São Paulo.

10: Heverson A. Tamashiro e Letícia 
Barreto da Cunha. Residência MA\&A, São Paulo, 1998. Desenho do autor.

11: Wassili Luckhardt. Cristal on the Sphere, 1920. Projeto para um edifício religioso (segunda versão); lápis de cera. PEHNT, W. (1973). Expressionist architecture. London: Thames and Hudson, p.37.

12: Antonio Sant' Elia. Assinado e inscrito

"La Città Nuova, detail" 1914. Musei Civici, Como. MEYER, E. C. (1995). The work of Sant' Elia: retreat into the future. Yale University.

13: Mies van der Rohe. Edifício de escritórios na Friedrichstrasse, Berlin, 1919. Carvão e lápis. LAMPUGNANI, V. M. (1983). Dibujos y textos de la arquitectura del siglo XX. Utopia y realidad. Barcelona: Gustavo Gili, p.48.

14: Heverson A. Tamashiro e Letícia Barreto da Cunha. Residência H\&C, Bertioga, SP, 1998.

[2]

\section{Constatação do atual ensino de desenho arquitetônico} Análise dos manuais de desenho arquitetônico

As ilustrações 2, 3, 11, 12, 14, 15, 16, 17 foram extraídas de OBERG, L. (1979). Desenho Arquitetônico. Rio de Janeiro: Ao Livro Técnico.

As ilustrações 4, 6, 7, 8, 9 e 10 foram extraídas de OBERG, L. (1950). Curso de Desenho Arquitetônico para arquitetos, desenhistas e construtores. Rio de Janeiro: Gertum Carneiro (Biblioteca FAU Mackenzie, 12/04/2003).
As ilustrações 19, 21, 25, 26, 27, 28, 29, 30 e 31 foram extraídas de MONTENEGRO, G. (1987). Desenho arquitetônico. São Paulo: Edgard Blucher ( $2^{a}$ edição, de 1985; $1^{\circ}$ reimpressão, 1987).

As ilustrações 18, 20, 22, 23, 24 e 32 foram extraídas de MONTENEGRO, G. (2001). Desenho arquitetônico. São Paulo: Edgard Blucher (4a edição, de 2001; $1^{\text {a }}$ reimpressão, 2002).

As ilustrações 33, 49, 50, 51, 52, 53, 54, 55, 56, 57, 58, 59, 60, 61, 62 e 63 foram extraídas de CHING, F. D. K. (1999). Manual de dibujo arquitectónico. México: Gustavo Gili.

As ilustrações 37, 39, 40, 41, 42 e 43 foram extraídas de CHING, F. D. K. (1999). Dicionário visual de arquitetura. São Paulo: Martins Fontes.

As ilustrações $38,44,45,46,47$ e 48 CHING, F. D. K. (1998). Arquitetura: forma, espaço e ordem. São Paulo: Martins Fontes ( $2^{\mathrm{a}}$. Tiragem, 1999).

As ilustrações 36, 64, 65, 66 e 67 foram extraídas de CHING, F. D. K.; ADAMS, C. (2001). Técnicas de construção ilustradas. Porto Alegre: Bookman.

As ilustrações 68a, 68b, 69, 71 e 72 foram estraídas da norma da ABNT - ASSOCIACC̃̃O BRASILEIRA DE NORMAS TÉCNICAS (1994). NBR 6492: Representação de projetos de arquitetura: elaboração. Rio de Janeiro.

1: Lamartine Oberg, foto da década de 1960. Fonte: página eletrônica http: / /www.esdi.uerj.br/arquivos / imagens/esdi60.pdf (p.15), acessado em 13.07.2003.

2: Capa da $22^{\mathrm{a}}$ edição.

3: Capa da $34^{\mathrm{a}}$ edição.

4: Folha de rosto da edição de 1950.

5: Folha de rosto da edição de 1963. OBERG, L. (1963). Curso de Desenho Arquitetônico para arquitetos, desenhistas e construtores. Rio de 
Janeiro: SEDEGRA-Sociedade e Editora Gráfica (Biblioteca FAU Mackenzie, 12/04/2003).

6: Foto de uma sala do Instituto Técnico Oberg, presente na edição de 1950.

7: Prefácio da edição de 1950.

8: Exercício para desenhar uma residência: Planta (edição de 1950).

9: Exercício para desenhar uma residência: Corte $A B$ (edição de 1950).

10: Exercício para desenhar uma residência: Corte CD (edição de 1950).

11: Símbolos convencionais: p.12 (22 edição, de 1979).

12: Símbolos convencionais: p.13 (22 edição, de 1979).

13: Sugestão de representação de caixilho em várias escalas. Desenho do autor.

14: Ampliação de caixilho, p.46 (22 ${ }^{\mathrm{a}}$ edição, de 1979).

15: Corte de um edifício residencial, p. 95 (22ª edição, de 1979).

16: Escada, p.57 (22 edição, de 1979).

17: As cotas de uma planta, p.25 (22 edição, de 1979).

18: Foto do autor, na página $167 \mathrm{da}$ $4^{\mathrm{a}}$ ediçãa, de 2001 (1 $1^{\mathrm{a}}$ reimpressão, 2002).

19: Capa da $2^{a}$ edição, de 1985 (1º reimpressão, 1987).

20: Capa da $4^{\mathrm{a}}$ edição, de $2001\left(1^{\mathrm{a}}\right.$ reimpressão, 2002).

21: Primeiros traços $d$ desenho de uma planta, p.67 (edição de 1985).

22: Primeiros traços (a lápis) de desenho de uma planta, p.78 (edição de 2002).

23: As alvenarias de uma planta, p.64 (edição de 2002).
24: As alvenarias de uma planta, p.64 (edição de 2002).

25: As cotas, p.37 (edição de 1985).

26: As cotas, p.38 (edição de 1985).

27: As cotas, p.39 (edição de 1985).

28: As cotas nos desenhos, p.69 (edição de 1985).

29: Desenho de corte de uma residência, p.71 (edição de 1985).

30: Desenho de corte de uma residência (cap. 19), p.129 (edição de 1985).

31: Desenho de corte de um edifício, p.135 (edição de 1985).

32: Desenho de um corte, p.105 (edição de 2002).

33: Capa do Manual de dibujo arquitectónico.

34: Capa do Representação gráfica em arquitetura. CHING, F. D. K. (1999). Porto Alegre: Bookman, $3^{\text {a }}$.ed.

35: Capa do Representação gráfica para desenho e projeto. CHING, F. D. K.; JUROSZEK, S. P. (2001). Barcelona: Gustavo Gili.

36: Capa do Técnicas de construção ilustradas.

37: Capa do Dicionário visual de arquitetura.

38: Capa do Arquitetura: forma, espaço e ordem.

39: Esquema estrutural, p.103.

40: Detalhe de janela 1, p.155.

41: Detalhe de janela 2, p.155.

42: Elevador, p.93.

43: Form decking, p.220.

44: Residência Gwathmey, Amagensett, 
Nova York, 1967, Charles Gwathmey/ Gwathemey Siegel, p.49.

45: Edifício John Deere \& Company, Moline, Illinois, 1961-64, Eero Saarinen \& Associados, p.88.

46: Estudo de projeto de Van Doesburg e Van Esteren, 1923, p.85.

47: Escada da Espanha, Roma, 1721 25, Alessandro Specchi e Francesco de Sanctis, p.20.

48: Casa de Vidro, New Canaan, Connecticut, 1949, Philip Johnson, p.117.

49: Dureza da mina do lápis, p.3.

50: Projeções ortogonais do desenho arquitetônico, p.18.

51: Explicando a planta, p.18.

52: Explicando o corte, p.34.

53 a 56: Seqüência de desenho de planta, p.22-23.

57: Desenho de planta em várias escalas, p.24.

58: Portas e janelas em planta, p.26.

59: Secção de desenho, p.39.

60: Secção da construção, p.39.

61: Exploração do valor tonal do grafismo, p.100.

62: Árvores e paisagens, p.136.

63: Árvores e paisagens, p.135.

64: Axonométrica explodida apresentando os elementos de uma edificação, p.2.9.

65: Dispositivos de ancoragem em estruturas metálicas, p.5.41.

66: Detalhe de estrutura de cobertura em aço, p.6.20.
67: Tipos de janelas por operação, p.7.22.

68a: Indicação de cotas de nível, item A-10.3, NBR 6492, p.17.

68b: Cotas de vãos de portas e janelas, item A-9.2, NBR 6492, p.16.

69: Cotas, NBR 6492, item A-9-1, p.16.

70: Cotas, NBR 10126, fig. 10, p.4. ASSOCIAÇÃO BRASILEIRA DE NORMAS TÉCNICAS (1987). NBR 10126: Cotagem em desenho técnico: elaboração. Rio de Janeiro.

71: Marcação dos cortes gerais, NBR 6492, p.19.

72: Marcação de detalhes, NBR 6492, p.21.

\section{Considerasões finais}

73: Capa do livro

Desenho de Arquitetura. FERREIRA, P. (2001). Rio de Janeiro: Ao Livro Técnico. 


\section{Normas:}

ABNT - ASSOCIAÇ̃O BRASILEIRA DE NORMAS TÉCNICAS: NBR 8402, Mar/1994, Execução de caracter para escrita em desenho técnico; NBR 10647, Abr/1989, Desenho técnico; NBR 10067, Mai/1995, Princípios gerais de representação em desenho técnico - vistas e cortes; NBR 10582, Dez/1988, Conteúdo da folha para desenho técnico; NBR 13272, Fev/1995, Elaboração da lista de itens em desenho técnico; NBR 13278, Fev/1995, Referência $a$ itens em desenho técnico; NBR 8196, Dez/1999, Emprego de escalas em desenho técnico; NBR 10126, Nov/1987, Cotagem em desenho técnico; NBR 8403, Mar/1984, Aplicação de linhas em desenhos - tipos e largura das linhas; NBR 10582, Dez/1988, Apresentação da folha para desenho técnico; NBR 10068, Out/1987, Folha de desenho - layout e dimensões; NBR 6492, Abr/1994, Representação de projetos de arquitetura.

AIA - AMERICAN INSTITUTE OF ARCHITECTS (1981). Architectural Graphics Standards. New York: John Willey. Autor secundário: Packard, Robert T. (EPEP $72.02^{\wedge} \mathrm{AM} 35 \mathrm{a} 7$ )

DIN 1356 - Normalização para projetos de construção em arquitetura, em BACHMANN, Albert; FORBERG, Richard (1976). Desenho Técnico. Trad. Inácio Vicente Berlitz. 2a. ed. Porto Alegre: Globo (EESC 744 B124d/port e.3, p.3)

\section{Livros de Desenho Técnico:}

Richard (1976). Desenho Técnico. Trad. Inácio Vicente Berlitz. 2a. ed. Porto Alegre: Globo (EESC 744 B124d/ port e.3, p.3)

CUNHA, Luís Veiga da (1997). Desenho Técnico. Lisboa: Fundação Calouste Gulbenkian, 10a.ed. (Mackenzie 744. c914d)

FRENCH, T. E.; VIERCK, C. J (1985). Desenho Técnico e tecnologia gráfica. São Paulo: Globo. ISBN 85-250-0733-1 (atualmente há a versão de 1999; na Biblioteca Central da EESC, as edições são do ano de 1960) (do autor)

MICELI, Maria Teresa; FERREIRA, Patrícia (2001). Desenho técnico básico. Rio de Janeiro: Ao Livro Técnico (do autor, cortesia da editora)

GIESECKE, F. E. (2002). Comunicação Gráfica Moderna. Trad. Alexandre Kawano (et al). Porto Alegre: Bookman (do autor, cortesia da editora)

KAWANO, A. e outros (1997). Desenho para Engenharia I. São Paulo: EDUSP. (apostila PCC 117) (de Maria Ângela)

Desenho para Engenharia II (1998). São Paulo: EDUSP. (apostila PCC 118) (de Maria Ângela)

MACHADO, Ardevan (1980). Desenho na Engenharia e Arquitetura. São Paulo: o autor. (EPEC $744^{\wedge} \mathrm{M} 18 \mathrm{~d} 3$, FAU

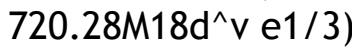

PEREIRA, Aldemar (1977). Desenho Técnico Básico. Rio de Janeiro: Francisco Alves; FENAME. (de David Moreno Sperling) 
Livros de história do desenho técnico e do desenho de arquitetura:

DEFORGE, Yves (1981). Le graphisme technique. Son histoire et son enseignement. Paris: Editions du Champ Vallon. ISBN 2-903528-11-X (Prefácio de Abraham A. Moles). (de Maria Ângela)

SAINZ, Jorge (1990). El dibujo de arquitectura. Teoria e História de un Lenguaje Grafico. Madrid: Editorial Nerea. (de Hugo Segawa)

OLIVEIRA, M. M. de. (2002). O desenho de arquitetura pré-renascentista. Salvador: UFBA, (livro a adquirir direto com a editora).

\section{Manuais ou Livros de Desenho Arquitetônico propriamente dito:}

CHING, Francis D. K. (1999). Manual de dibujo arquitectónico. México: Gustavo Gili (do autor).

(1999). Representação Gráfica em Arquitetura. Trad. Por Luiz A. Meirelles Salgado. 3a. ed. Porto Alegre: Bookman. ISBN 85-7307-5260 (do autor, cortesia da editora).

CHIGUIR, Margarita. Curso de desenho arquitetônico. São Paulo: Gráfica Editorial Ltda. Vol. I a V (informado por professores da UFBA).

DAGOSTINO, Frank R. (1980). Desenho arquitetônico contemporâneo. São Paulo: Hemus. (FAU / 720.28^D134d)

FERREIRA, Patrícia (2001). Desenho de arquitetura. Rio de Janeiro: Ao Livro Técnico. (do autor, cortesia da editora)

MOIA, J. L. (1944). Curso completo de desenho arquitetônico. Buenos Aires: Windsor (FAU 744.42^M873e)

MONTENEGRO, Gildo A. (1978). Desenho arquitetônico. São Paulo: Edgard Blucher (EESC 720.28 M777 d e.2) / (3a.ed., 1997, Biblioteca Mackenzie) / (3a. reimpressão, 1999) / (4a. ed., 2001 e 1a. reimpressão, 2002; do autor)

MULLER, Edward John (1967). Architectural Drawing and Light Construction. (FAU /744.42^M913a)

NEVES, J. M. da S. (1943).

Desenho arquitetônico. São Paulo: Cupolo. (O autor foi professor da Politécnica e discípulo de Dubugras) (FAU 744.42^N414d, EESC/ Tese $^{\wedge}$ N518d)

OBERG, Lamartine (1950). Curso de Desenho Arquitetônico para arquitetos, desenhistas $e$ construtores. Rio de Janeiro: Editora Gertum Carneiro S/A. (Mackenzie 744.424 Ob2e).

- (1963). Curso de Desenho Arquitetônico para arquitetos, desenhistas e construtores. Rio de Janeiro: Sedegra Sociedade Editora e Gráfica. (Mackenzie 744.424 Ob2e).

(1979) Desenho arquitetônico. Rio de Janeiro: Ao Livro Técnico. EESC 720.28 OL 12d.21 (do autor) / (34a. ed., 1997: do autor, cortesia da editora)

SANTOS, E. G. dos (1980). Arte de desenhar. São Paulo: Livr. Edit. Gráf. Santos. (EESC 720.28 S237a)

SESSA, F.; FRANCO, V. M.; MARTINS, P. E. R. (_). Desarq 1, 2 e 3. Porto 
Alegre: GG Edições Técnicas (de Maria Ângela)

\section{Livros que, indiretamente, ensinam o desenho arquitetônico:}

BROADBENT, Geoffrey (1971). Metodologia del diseno arquitetônico. Barcelona: Gustavo Gili. (EESC 720.28 M593)

CHING, Francis D. K. (1998). Arquitetura: Forma, Espaço e Ordem. Trad. por Alvamar Helena Lamparelli. São Paulo: Martins Fontes; $2 a$. tiragem, 1999. (do autor)

(1985). Architectural Graphics. New York: John Wiley Professio (4a.ed., New York: John Wiley \& Sons, 2003 (ISBN 0-47120906-6, pesquisado em livraria de São Paulo)

- (1999). Dicionário visual de arquitetura. São Paulo: Martins Fontes. ISBN 85-336-1001-7 (do autor)

.; JUROSZEK, S. P. (2001). Representação Gráfica para Desenho e Projeto. Trad. por Anamaria Costa Martins, versão portuguesa. Barcelona: Gustavo Gili. ISBN 84252-1848-9 (de Hugo Segawa / capa azul).

.; ADAMS, Cassandra (2001). Técnicas de Construção Ilustradas. Trad. por Luiz Augusto M. Salgado e equipe. Porto alegre: Bookman (de Naguissa Yuba). (Edição original na Biblioteca Central EESC: CHING, Francis D. K.; ADAMS, Cassandra (1991). Building Construction
Illustrated. New York, Van Nostrand Reinhold, 2o.ed. (EESC 690 C539b.2 e.2)

GARCIA-RAMOS, F. (1976). Prácticas de dibujo arquitectónico. Barcelona: Gustavo Gili.

GOODBAN, Willian T. (1972). Architectural drawing and planning. New York: Mc Graw Hill. (FAU USP 720.28 G611a)

HORNUNG, William J. (1966). Architectural drafting. N.J.: Prentice Hall, 4a. ed. (FAU /720.2^H785a^e.1)

PANERO, Julius; ZELNIK, Martin (2001). Dimensionamento humano para espaços interiores. Um livro de consulta e referência para projetos. Barcelona: Gustavo Gili. Trad. Por Anita Regina Di Marco. ISBN 84-2521835-7. (de Hugo Segawa) / (FAU-PGR /572.087:72^P191d) / (EESC ...)

REGO, Nadia Vilela de Almeida (2002).

Tecnologia das construções. Rio de Janeiro: Ao Livro Técnico (do autor, cortesia da editora)

SPENCE, Willian Perkins (1993). Architectural working drawings: residential \& commercial buildings. New York: John Wiley. (FAU/USP $720.28 \mathrm{Sp} 32 \mathrm{a}$ )

\section{Livros de ilustração que, também, indiretamente, ensinam o desenho arquitetônico:}

BURDEN, E. (1984). Modelos gráficos para el diseno arquitectónico. Mexico: 
Gustavo Gili. (EPEC 72.02^B896m2 /

Fau $720.28^{\wedge}$ B869d)

- (1984). Design presentation.

New York: McGraw-Hill. (FAU /720.28^B896d)

COULIN, C. (1962). Drawings by architects from de ninenth century to the present day. New York: Van Nostrand Reinhold. (FAU /744.42^C831d)

(1982). Step-by-step perspective drawing for architects, draftsmen, and designers. New York: Van Nostrand Reinhold, c1966. (FAU /742^C831s)

DOYLE, Michael E. (1999). Color Drawing: design drawing skills and techniques for architects, landscape architects, and interior designers. New York: John Wiley. ISBN 0-47129245-1 (do autor) (a Biblioteca Central EESC adquiriu recentemente: ...)

FRASER, I.; HENMI, R. (1994).

Envisioning architecture: an anasysis of drawing. New York: John Willey \& Sons, Inc. (EESC 720.28 F841e / UFPR 720.284 F842) (ISBN 0-471-28497-3)

JACOBY, Helmut (1981). El dibujo de los arquitectos. Barcelona: Gustavo Gili, 167 p. (FAU /720.28^J159d) / (EESC ...)

HALSE, A. O. (1960). Architectural Rendering: the techniques of contemporary presentation. New York: Mc Graw-Hill/Dodge. (FAU /744.42^H165a / UFPR 720.223 $\mathrm{H} 196)$

KEMMERICH, C. (1968). Detalhes gráficos para arquitectos. Barcelona: Gustavo Gilli. (UFPR 720.28 K31e 2a.ed. / FAU /744.42^K317d)

LAMPUGNANI, Vittorio Magnano
(1983). Dibujos y textos de la architectura del siglo XX. Utopia y realidad. Barcelona: Gustavo Gili. (FAU /720.28^L199d)

LIN, Mike. W. (1985).

Architectural Rendering Tecniques. New York: Van Nostrand Reinhold. ISBN 0-442-25953-0 (do autor) . (1993). Drawing and Designing with confidence, a step-by-step guide. New York: Van Nostrand Reinhold. ISBN 0-442-00176-2 (parece que está esgotado, mas ainda aparece nos lojas virtuais de internet). (SAP EESC USP/Prof. Marisa)

LITTLEWOOD, M. (1993). Landscape Detailing 1 e 2. Reed Educational and Professional Publishing Ltda. (EESC ... / ( London, Architectural, 1986: FAU /712^L735l)

PICKERING, E. (1941). Architectural design. New York: John Willey \& Sons, Inc; London, Chapman \& Hall limited. (FAU 744.42^P586a e. 1 e 2 / Fau PGR 72.021.22^P595a)

PORTER, T.; GRENSTREET, B.(1991). Manual de Tecnicas graficas para arquitectos, diseñadores y artistas. Barcelona: Gustavo Gili, 1991. (EESC ...) (New York: Scribner's, 1980 FAU $\left./ 741.4^{\wedge} \mathrm{P} 835 \mathrm{~m}^{\wedge} \mathrm{v} .1,2,3\right)$

VANDYKE, S. (1990). From line to design: design graphics communication. 3.ed. New York: Van Nostrand Reinhold. 198 p. ISBN 0-44200113-4. (EESC 720.28 V248f.3).

\section{Livros práticos de arquitetura que, indiretamente,}




\section{ensinam o desenho arquitetônico:}

VITALI, R. (1952). Trattato di disegno edile. Genova: Edizione Vitali e Ghianda, 1952. (EESC 720.28 V836 t.3 / FAU 744.42^V831t)

\section{Apostilas, iniciativas de professores de desenho arquitetônico:}

BORTOLUCCI, M. A. P. C. S. ; ROCHA, C. (1994). Desenho Arquitetônico. São Carlos: EESC/USP. Apostila.

UNTAR, J.; JENTZSCH, R. (1977). Desenho Arquitetônico. Viçosa: UFV. Destina-se às aulas práticas do curso de Desenho Técnico - CIV 100, do Departamento de Engenharia Civil da UFV. (É menos profundo que Oberg) (PUCPR 720.284 U61 Acervo 33705)

\section{Manual ou apostila de Escola Técnica:}

Liceu de Artes e Ofícios de São Paulo - Escola técnica (1995). Cotagem. São Paulo (da aluna Adriana Z. Fonseca, da graduação CAU EESC USP)

Escola PROTEC. ). Desenho de Arquitetura. Curitiba: Escola Protec (UFPR 720.284 E74)
Outros:

CABRITA, A. M. R. (1974). Regras para elaboração de projetos. Informação Técnica Edifícios 6. Lisboa: MOP Laboratório Nacional de Engenharia Civil. (do Prof. Admir Basso)

NICOLAIDES, K. (1969). The natural way to draw. Boston: HoughtonMifflin (do arquiteto Eurico Ugaya).

VIGNOLA, G. B. (19-?). Tratado prático elementar de architectura ou estudo das cinco ordens, segundo Jacques Barozzio Vignola. Rio de Janeiro: Garnier. (FAU 744.42^V686t e1a4. / EESC ...)

ALBERNAZ, Maria Paula; MODESTO, Cecília (2000). Dicionário ilustrado de arquitetura. São Paulo: ProEditores. (de Maria Ângela, 2 volumes / o Prof. Admir Basso o tem num só volume, de 2001) (FAU R /720.3^AL14d) 


\section{Entrevista com Luiz Gastão de Castro e Lima}

\author{
Arquiteto e Professor \\ Luiz Gastão de Castro e Lima \\ Data: 20.11.2002 \\ Local: Residência - R Visconde de \\ Inhauma, 1344 - São Carlos-SP
}

Hev: Prof. Gastão, viemos conversar com o senhor, pela importância como profissional arquiteto e também como professor na área de desenho e projeto. Também pela importante participação na definição e montagem do curso de arquitetura. Sabemos que foi chefe do SAP na época da abertura do nosso curso de graduação e foi um dos fundadores do Pós.

\section{$[\ldots]$}

Hev: Em que ano você nasceu?

Gastão: É, outubro de 1927.

Hev: A Ângela falou que o senhor se formou em uma das primeiras turmas da FAU.

Gastão: Eu, quando fui fazer arquitetura, não existia a FAU. Existia o Mackenzie e eu entrei na Escola Politécnica. Lá havia o curso de engenheiros-arquitetos, isso em 1940. A FAU foi fundada em 1949, né? Em 1947, se não em engano. E a FAU foi fundada dois anos depois que eu estava na Politécnica e eu não quis prosseguir o curso de engenheiroarquiteto. Eu achei que deveria recomeçar um curso específico de arquitetura, que seria a FAU, porque a Politécnica era um curso bom e que eu terminaria com a minha turma, mas era um curso muito voltado para a engenharia civil. E eu não tinha muito interesse em ser calculista ou qualquer coisa neste sentido, embora eu gostasse disso também, mas não tinha tanto interesse em ter esse enfoque tão forte em meu curso. Então, eu abandonei a Escola Politécnica em 1948, quando foi fundada a FAU. Então eu sou da segunda turma da FAU. A primeira foi a turma que fundou a FAU.

Hev: E recomeçou?

Gastão: Recomecei tudo. Não me aceitaram como transferência ... Era bobagem qualquer de diretor que achou que era da lei não sei o que, porque tinha uma diferença no vestibular pequena e aí eu fiz de novo. Fiz, passei e aí eu tirei umas dispensas de disciplinas que eu já tinha feito e não valia a pena discutir ... Mas, fora os aspectos políticos, eu fiz o curso e tornei arquiteto e, depois, eu fiquei mais um ano na FAU. Eu parei um ano, fiquei doente, com um certo problema, ... então me formei em 1954.

Hev: Naquela época como era o ensino do desenho arquitetônico; tem o desenho livre ...

Gastão: Não existia.

Hev: Não existia? Na FAU, desde aquela época não existia ...?

Gastão: Não, não existia no curso uma disciplina específica de desenho arquitetônico, absolutamente. $\mathrm{Na}$ antiga Escola Politécnica, no curso de engenheiros-arquitetos existia um curso que se chama Desenho em perspectiva; e era no segundo ano do curso de engenheiros-arquitetos. Nesse curso se aprendia a fazer perspectivas arquitetônicas no geral e, ... vamos dizer, como o professor encarava o curso. Era o professor com quem eu fui assistente, Silvio Anelis. Era uma disciplina que se chamava naquela época, né? Havia diferença entre cadeiras e disciplinas. Cadeira 
era do catedrático, era aquele proprietário das abordagens e tudo o mais. E disciplina era um curso, uma pequena catedrazinha mas com pequena abrangência, só daquelas disciplinas. Então, aquela disciplina de desenho em perspectiva era do Silvio Anelis, que era professor e, depois, passou a ser professor da FAU também. Mas não existia um curso de desenho, o que existia era geometria projetiva, aliás descritiva. O curso era de geometria descritiva, porque o pessoal entendia - isso na Politécnica também porque o curso era Descritiva, o curso completo -, que a Descritiva era a base de tudo. Então, aprendia tudo na Descritiva.

Hev: Aprendeu projeções ...ortogonais ...

Gastão: Tudo ... Aplicações das descritivas, sem dúvida, ... alguma coisa. Não duvido, não tenho nenhuma crítica em relação a isso, quer dizer, ela é a mãe do desenho, isso de uma maneira geral. Só que é uma mãe "torta" porque quando você estuda a descritiva, você não está preocupado com casos particulares de descritiva ... uma reta fura um plano, com o encontro da pirâmide não sei o quê mais, do que com a representação. Você perde o sentido da representação na medida em que você acha que a descritiva é que te dá base para você saber o desenho. Então, todos os cursos daquela ocasião enfatizavam a descritiva como fundamento de tudo. Então, na FAU não existia o curso de desenho específico. Acho que até hoje não existe ... um curso, uma ... disciplina ligada ao desenho arquitetônico.

Hev: Na FAU. Há sete anos atrás, eu perguntei para um aluno de $1^{\circ}$ ano, de $2^{\circ}$ ano e fiquei surpreso que eles nunca usaram régua $T$ no $1^{\circ}$ ano, ele fazia tudo em croqui, a mão livre e, agora, eu confirmei com uma aluna que se transferiu para lá e existe uma disciplina que se chama Fundamentos de Projeto, no $1^{\circ}$ ano, que acaba ensinando um pouco este vocabulário da planta, corte, vista ... Mas não tem mesmo.

Gastão: Não existe, né? O que existia era a descritiva.

Hev: Que ainda hoje existe. Ela me confirmou isso. E aqui, nunca teve?

Gastão: Aqui, de origem? Bom, aqui existia o ... quando eu comecei a dar aula aí, eu comecei a dar aula de desenho, ... só que não existia o curso de arquitetura, que vem bem depois. Então, havia desenho para as engenharias. Mas o curso, o departamento de arquitetura dava disciplinas ligadas a Humanidades e Desenho. Humanidades, depois. 0 curso de desenho arquitetônico ... o que existia era a geometria descritiva.

Hev: A cadeira, a disciplina que o Prof. Silvio Anelis dava, em desenho de perspectiva era com aquarela, era naquele esquema de Belas Artes?

Gastão: Era um pouco. Sabe, quem dava mais essa parte de aquarelas e tudo era um camarada chamado Felisberto Ranzini, que também está na história, que foi um dos que trabalhou - como é que se chama o grande construtor de São Paulo? - com Ramos de Azevedo. O Ranzini era um daqueles italianos trazidos pelo Ramos e era um belíssimo aquarelista, sabe? Foi ele quem fez o mercado municipal de São Paulo. Foi um dos autores do mercado municipal. E o Ranzini deu aula um tempo na FAU. Sabe, ele era uma figura interessante. Mas isso na FAU, né? Na Politécnica não tinha. $\mathrm{Na}$ Politécnica o Silvio Anelis tinha o desenho em perspectiva e ele ensinava técnicas de perspectiva, o que o pessoal chama de perspectiva 
dos arquitetos, aquela mais prática, que você põe a planta e faz um V, ... sempre usei ... como todo mundo usa, né?

Hev: É, eu ensino desse jeito.

Gastão: É, ensina desse jeito, né? E eu acho ótimo isso. Eu aprendi aquilo no ginásio; o professor do ginásio ensinou. Dizia que era o método do professor Brown. Ele que inventou o professor Brown, né? Mas era aquele sistemão que abaixo do plano principal da linha de terra, você punha a planta e fazia as linhas de fuga paralelas, exatamente este método. Bom, isso era o que a gente usava com o Silvio Anelis, ... só que depois dava o acabamento chamado artístico. Você então fazia ou a bico de pena, ou fazia preto e branco, ou fazia aquarelado ... Era um curso de dois anos, na Politécnica, o desenho em perspectiva. A gente não teve na escola de arquitetura. Na escola de arquitetura nós tínhamos é, dois anos de geometria descritiva que, naquela ocasião, no tempo da Poli, era o professor Cruz, que chegou a servir a toda a FAU. O pessoal apelidavao de Cabrão. Não sei porque era o apelido dele lá. E o Cabrão era muito exigente; ele falava que ele era um grande admirador da descritiva e dos livros clássicos de Descritiva e tudo o mais, entendeu? Mas nunca tivemos um curso específico de desenho arquitetônico. Não teve mesmo, quer dizer, a prática o pessoal fazia nos escritórios. lam nos escritórios e aprendiam, ... todos os alunos que faziam estágio nos escritórios ... e aprendiam o processo de representação usual dos escritórios de arquitetura.

Hev: Então, essa história é desde o início?

Gastão: Desde o início.

Hev: As escolas técnicas que ensinavam?

Gastão: As escolas técnicas tinham um curso completo. Quando eu comecei a dar aula aqui (em São Carlos) no curso de arquitetura, ... a parte de Humanidades veio posteriormente. 0 curso de arquitetura, o departamento de arquitetura dava disciplinas para o curso de engenharia civil. Então, era um curso de desenho, desenho de maneira geral, que era para todos os cursos de engenharia: engenharia civil, mecânica, elétrica ...

Hev: Até hoje a Ângela dá e eu também dou.

Gastão: E, então, depois, disciplinas de arquitetura e urbanismo, já específicas do curso, entendeu? Mas o curso de desenho era um curso básico e eu fiquei, então, nessa disciplina durante algum tempo, mas eu tinha uma certa implicância com a descritiva. Eu tinha feito o curso completo de descritiva e eu não achava que a descritiva fosse fundamento de coisa nenhuma, porque você se perdia na descritiva. ... Por isso que eu fiz parte desse programa lá de Brasília. ... Foi quando o Rui Vieira foi do departamento de ações dos universitários. Naquela época eles pretendiam fazer os currículos mínimos, todos, ... estavam fazendo os currículos mínimos da engenharia, de todos os cursos, inclusive os das engenharias. E o Rui era muito amigo meu. Fui convidado, então, junto com um professor do Paraná e mais um cara lá do Rio Grande do Sul que, inclusive, mexia com desenho industrial, ... um professor do Paraná e mais um da Politécnica, se não me engano, inclusive o famoso homem das curvas, um professor da Politécnica, já aposentado, que vive discutindo as curvas de estrada, o balanceamento das curvas de estrada.

Hev: Ardevan Machado? 
Gastão: Ardevan, Ardevan, Ardevan é um ... O Ardevan também fez parte disso.

Hev: Você conhece o Semi Ammar, ... dava aulas no Mackenzie ...?

Gastão: Conheci o Semi Ammar ... Bom, naquela época, nós discutimos muito o programa do desenho na engenharia e a minha tese é de que a descritiva deveria ser abolida. Eu era radical nisso; eu achava que você deveria ensinar aplicações da descritiva como curso básico, alguns aspectos básicos de linguagem de desenho. E que os cursos que envolvessem projeto fossem dados especificamente pelas áreas. Por exemplo, engenharia elétrica: não adianta você ensinar desenho elétrico para os caras, porque os caras vão ter que saber desenho elétrico nos momentos de projetos de engenharia elétrica; assim como os desenhos mecânicos. Eu achava que não adianta você fazer corte e fachada e corte retirado e corte não sei mais o quê das quantas para engenheiro. 0 curso normal de engenharia, ... que o cara ia aprender isso quando fosse fazer desenho mecânico na Mecânica; e aqui se implanta um ... Não tem sentido ... que os professores das áreas mais avançadas, Paulo Trevezin era um deles, eles achavam que o problema do desenho não é nosso: vocês tem que ensinar desenho para os meninos e nós vamos só usar os conhecimentos deles. $\mathrm{E}$ eu achava que não: o problema de desenho era de vocês; nós vamos dar os fundamentos de desenho para os meninose vocês vão ensinar as especificidades dos desenhos mecânico e elétrico. Então, nunca chegamos a um acordo, né?

Hev: Será que fazendo um pouco de geometria descritiva, o aluno tem uma cabeça melhor para pensar tridimensionalmente?
Gastão: Não acredito muito, não acredito muito! Porque eu acho que o perigo da descritiva é você fazer a descritiva pela descritiva.

Hev: É aquele caso de encontro de duas águas, casos pontuais ...

Gastão: É fazer a descritiva pela descritiva. Esse é o que eu acho que é o problema, entendeu? Eu acho que se você tem desenho, você tem que treinar o cara usar a mão, usar a cabeça, estabelecer uma relação entre a mão e a cabeça e, principalmente, treinar o traço, né? Estudar as possibilidades, eu acho, estudar as possibilidades que o traço lhe dá como meio de expressão ... Isso é o que eu pensava, né? Tanto que o meu doutorado foi em cima disso. O meu doutorado foi muito simples, muito singelo. A gente estava começando a fazer doutorado. Mas eu me lembrei muito como fundamento daqueles seminários da Bauhaus, 0 que o pessoal fazia. Faziam desenhos usando prato, garfos, tipo pop-art, entendeu? A expressividade do traço e o domínio desse traço expressivo. Então, eu achava que era, ... que como curso fundamental, aquilo era excelente, pelo que correspondeu os cursos preliminares da Bauhaus. Então eu achava que descritiva ... sei lá, ... deveria ser até um curso avançado. Tanto que hoje em dia a própria computação gráfica, quase toda, se baseia nas perspectivas. Ela é descritiva fundamental, ela tem embutida todo o know-how da perspectiva, ... a computação gráfica, né? Então, eu acho que para isso, ela é fantástica. Agora, a minha tese, a minha hipótese, vamos dizer, ... era o seguinte: à medida que vamos avançando no conhecimento, você não sabe mais como é que você vai propor um curso para os caras, porque tudo aquilo que vai ficando para trás, vai ficando superado e você tem a tendência 
de manter um conhecimento que você ... não dispõe, ... se vai dar certo, ... aquilo ali dá certo com uma coisa. É como matemática; por exemplo: hoje a matemática está nas nuvens e o cara não está aprendendo sério, ... coisas que, na realidade, são todas importantes, ... no conhecimento científico, de maneira geral. Agora, tem que saber selecionar, no aprendizado, aquilo que efetivamente tem objetivo.

Hev: O pessoal da Elétrica reivindicou que a gente, no desenho técnico, desse um pouco a mais de desenho à mão livre, para os alunos terem noção de proporção das coisas. Isso, porque, na hora de fazer projeto, eles não vão fazer à mão; mas no computador e, na hora de fazer um croqui de um circuito, saber que um capacitor é deste tamanho, ... perto de alguma outra coisa que é maior. Então, ... noção de proporção entre as coisas. $E$, também, agora, como está tendo os novos cursos de design, aeronáutica, ... aeronaves, ... eles estão querendo que a gente dê um pouco mais de enfoque para design nos curso de desenho técnico e não desenhos exaustivos de peças de mecânica, porque, na verdade, o aprendizado disso é rápido, ... vistas, cortes?

Gastão: Está certo! Eu acho que, talvez estejam retornando algumas origens da criatividade até. Porque o problema todoé: o que é fundamental? E tudo aquilo que você transmite a eles, o que é que fica, não? É a mera definição da cultura: é o que sobra depois que você esquece de tudo. É uma das definições, né? É o que sobra, ... é o caldinho que estabelece o seu fundamento. Então, o que é a cultura tecnológica? É só uma das coisas; é tudo que serve como base para você desenvolver os seus; e o desenho é isso. O que é importante, principalmente hoje? O que você tem? Mecanismos, ... sistemas, hipóteses, cronogramas, softwares, programas de computadores que você tem, em que você não precisa saber nada. Simplesmente saber usar as ferramentas que nos dão, ... no computador e fazer desenhos incríveis, ... perspectivas maravilhosas. Mas falta, realmente, aquele fundamento de você ter uma visão espacial das coisas e tudo o mais. Existia, antigamente, alguns grandes desenhistas que faziam perspectivas, no Brasil mesmo. Todos os escritórios tinham um grande desenhista, mas eu me lembro, em particular, de um americano chamado Ferris. Você conhece? Se você procurar na Biblioteca deve ter. O Ferris fazia coisas do arco da velha, a mão, usando ferramentas à mão livre. Tudo à mão livre, esquadros, réguas e tudo mais. Publicaram, se não me engano. As perspectivas do Ferris eram de babar. $\mathrm{E}$ eu acho que nenhuma perspectiva de computador hoje em dia chega no dedo mínimo das perspectivas que o Ferris fazia, com todo software, com tudo isso que existe ai. Nenhuma perspectiva dos programas CADs, Autocad ou outro se igualam àquilo que o Ferris fazia, ... mesmo lá nos Estados Unidos, eu acho. Isso não quer dizer que você vai deixar de usar os instrumentos novos, né?

[Fim do lado A da fita; início do B]

[...]

Gastão: Então, eu acho que ainda é uma obra aberta, .. o desenho de um modo geral. $E$ hoje, como há esses novos métodos, modernos, é uma obra mais aberta ainda. Porque o pessoal tem uma certa ojeriza para mexer no começo ...

Hev: Eu, como professor de desenho de arquitetura I no Departamento (SAP EESC), e como trabalhei muito com projeto executivo de arquitetura, penso no desenho arquitetônico para os alunos e eu acho que eu tenho 
uma grande contribuição como ferramentas para ensino de projeto: plantas, cortes, vistas ... É uma grande briga que eu tenho, porque eu queria mais horas-aula para isso e eles não me dão porque ...

Gastão: Essa é a dificuldade que eu me lembro. Eu fui professor da FAU muitos anos, até 1972,16 anos lá em São Paulo, na FAU. E o pessoal, nas grandes discussões do grupo de projeto, discussões com $0, \ldots$ uma das grandes discussões era que eles diziam: eles não sabem desenhar, tem que ter desenho arquitetônico aqui. Mas, nunca teve. Todo mundo falava que precisava ter, que isso, que aquilo, mas, na realidade, nunca deram um valor muito forte. E é uma disciplina, um grupo de disciplinas o desenho arquitetônico.

Hev: Eu conheci há pouco tempo o professor Minoro Naruto.

Gastão: O Minoro trabalhou conosco lá na ...

Hev: E ele é essa opinião: de que estava precisando ensinar desenho arquitetônico, que precisa porque ...

Gastão: Mas realmente nunca teve. Então, os caras que eram bons de desenho, ... ou eram naturalmente bons, caras que tinham já um jeito especial ou então se trabalhava em escritório.

Hev: Naquela época era formado em ...

Gastão: Em termos de autodidática. Então, tinha alguns colegas que eram precisamente bons. Eu nunca fui desses. Eu tenho um pouco mais de trabalho para chegar às coisas. Mas nós tínhamos colegas que eram talentosos e faziam assim, com uma facilidade. Inclusive alguns que já morreram. Tem um que é vivo, eu me lembro, que foi um grande desenhista, o Metredjan.

Hev: Ele está dando aula na (FAU da Universidade) São Judas (São Paulo).

Gastão: O espanhol era danado, desenhava com facilidade. E tivemos colegas que eram duríssimos; eram incapazes de fazer qualquer coisa, mas é porque, naturalmente, eles eram uns cretinos. Não tinha jeito; você não conseguia que eles fizessem melhor do que aquilo. Mas, entraram na FAU e, se entra, sai, né? Mas, no fundo, é aquela velha tese: o desenho é uma habilidade natural. Isso eu não tenho dúvidas, como a música também é. Você pode ensinar - cara a fazer relativamente bem, como faz em escolas de Belas Artes, como fazem nos conservatórios. Agora músico é musico e desenhista é desenhista, ponto final.Como o pessoal da televisão, antigamente. Então o cara que é bom, você não vai se enganar; o cara que não é bom, você vai dar, então, os fundamentos para ele poder sobrenadar. Porque o desenho é uma coisa que a pessoa nasce para; ... é um dom. Por isso que se separa os artistas bons dos artistas médios. Muitos podem fazer coisas razoáveis. $E$, no caso nosso, de professor, é justamente saber o que é básico, para o aluno saber aplicar e desenvolver a sua própria aptidão às teorias. Você tem que desenhar com a esquerda porque a esquerda que é criativa. Então, lá em Baurú tinha uma professora que era maníaca. Ela fazia cursos e estava estudando de como desenhar com a esquerda porque a esquerda parece que é o cruzamento, não? O lado direito é comandado pelo esquerdo e o lado esquerdo é comandado pelo direito. Não é comandado, mas basicamente é comandado pelo direito. E o lado direito é o lado criativo. Então, quem usa a mão esquerda é mais criativo. Então, tem uma fulana aí que acha 
que você tem que desenhar com a mão esquerda. Você conhece essa teoria, não? Nunca ninguém falou que isso realmente é assim, mas em todo o caso, acabam desenhando bem com a esquerda, né? Não sei se aumenta a criatividade das pessoas, mas isto é uma observação, ... normalmente, o canhoto é muito preciso, em geral. Pode ser uma coincidência, ... mas na realidade acontece isso.

Hev: Eu tenho um roteiro a seguir e, depois, eu queria mostrar alguns exemplos de como cotar um desenho. Aqui no Departamento, em São Carlos, ... o senhor voltou quando para São Carlos e começou a dar aula ou trabalhar aqui.

Gastão: Bom, eu comecei efetivamente a dar aula nos anos 66, 67, por aí. Aula de desenho.

Hev: Já aqui?

Gastão: É. Eu acumulava com a FAU, né? Eu me transferi para cá quando criaram a pós-graduação. Mas, eu tive um (intervalo), num tempo em que eu saí, eu vim para cá, para essa área de desenho. Antes, eu trabalhei como arquiteto da escola, em 1961; fiz alguns projetos como arquiteto da escola: anfiteatro, aquela habitação dos alunos; tudo que tem tijolinho a vista aí, fui eu que fiz, naquela ocasião. Depois eu saí, porque eu recebi um convite de Brasília para ir para lá, em 1969. Mas, acabei não ficando em Brasília. Fui até dar uma olhada e achei que a maré não era para peixe e continuei na FAU. E aí eu, em 1972 - estava fazer o doutorado -, o Paulo Camargo pediu para que eu ficasse. Então, eu me transferi para cá, em 1972. Foi, então, por volta dos anos 70, ... que eu dei aula e trabalhei como professor aqui.

Hev: Só antes um pouco, em São Paulo, você também trabalhou como arquiteto e desde estudante fez estágio?

Gastão: Fiz estágio quando estudante. Trabalhei, inclusive, já na FAU, com um professor de paisagismo, que era o Roberto Coelho Cardoso; trabalhei com ele e trabalhei com o Jorge Wilhein também. E, tive escritório, fiz alguns projetinhos, ... o mais famoso lá foi o laboratório Fleury, na Rua cincinato Braga, ... aquilo foi projeto meu; ... e algumas casas. $E$, na FAU, eu comecei a dar aula em 1956 e a disciplina chamava-se composição decorativa. Era o nome da disciplina na época. E a gente interpretava, ... eu junto com o professor Anelis, ... era uma espécie de fundamento de desenho industrial, de design; não de desenho industrial, de design. Trabalhava muito com mobiliário, com coisas nesse sentido; porque composição decorativa era uma disciplina até antiga no curso de arquitetura, em que você trabalhava com ornato, coisas desse tipo. Nós tiramos essa conotação e passamos por uma espécie de design de mobiliário igual, ... cadeira ... Fazíamos pequenos projetos. E depois eu passei para disciplina, para o grupo de comunicação visual, junto com a Élide. Eu fiquei lá, depois durante todo o tempo na área de comunicação visual.

Hev: Élide Monzeglio.

Gastão: É. O Julio Abe trabalhou conosco também. Mas a Élide, o Julio Abe e o Flávio Império - que depois faleceu -, mais posteriormente, ... também foi dessa área de comunicação visual. É que o Flávio era meio, ... um cara genial e, como todo cara genial, pirado de vez, né? Então, você não podia contar com ele para coisa nenhuma. Era um cara muito inteligente, capacitado, mas o calocávamos para dar aula e era "ruim" porque ele não tinha continuidade, não tinha, não era um 
... Eu sempre falei que o professor tem que ser um pouco "medíocre", professor genial é "ruim", para o curso. A pessoa tem que ter um pouco multiuso, não pode ser gênio. Mas isso no bom sentido, entende?

Hev: Interessante. É, senão não consegue passar ...

Gastão: Senão você não passa nada. Você chega lá, faz aquele troço e vai embora. É o que ele fazia. A Élide é o contrário, a Élide é um ... "pé-deboi" que não tem tamanho até hoje, que trabalhava 100 horas por dia, ... era aquele dia-a-dia eterno, né?

Hev: O Spencer está trabalhando até hoje.

Gastão: É. O Spencer foi um dos que nós selecionamos, quer dizer, eu que trouxe o Spencer ...

Hev: Ele é genial.

Gastão: É. O Spencer é uma mistura: ele é meio genial e meio ... , também. Você precisa segurar o Spencer de vez em quando na rede. Mas é ótimo; o pessoal adora o Spencer. E na ocasião daquele concurso eu fiquei com uma certa implicância com aquele cara porque aquele cara me parecia um cara que ia trazer muito pouco para um curso em que você tinha que, porque, o nosso problema - por isso que eu sempre impliquei com o cara por isso, eu tive experiência com o curso - o nosso problema não era arquitetura, era engenharia, entendeu? 0 curso de arquitetura tinha que continuar dando aula para engenharia. Então, você não podia contar com um professor que fosse genial para arquitetura; nós tínhamos que contratar um professor que fosse bom para a engenharia. $\mathrm{E}$ até hoje ainda há isso, uma carga que você não ..., que o curso não se livrou.
Hev: Seria bom se as engenharias fossem autônomas, que contratassem seus professores.

Gastão: Exatamente. Foi uma tese nossa naquela ocasião e eles não aceitaram.

Hev: E eu até queria oferecer uma optativa na arquitetura eu não tenho tempo porque eu preciso dar aula na engenharia. É um problema ... E o senhor deu aula a partir dos anos 70 até quando, aqui no departamento de arquitetura?

Gastão: Até 1986, quando me aposentei.

Hev: E acabou ajudando a formar o curso de arquitetura, a graduação?

Gastão: Sim; eu fiquei um grande par de tempo como chefe de departamento e coordenador da pós-graduação. Mas a idéia minha, naquela ocasião, ... o nosso trabalho foi firmar a pós-graduação o mais possível. Foi quando nos anos oitenta e poucos o diretor Martinelli, que foi meu colega na Poli inclusive, naqueles velhos tempos, quis reativar a idéia do curso de arquitetura, que era antiga já, do Paulo Camargo, e lutou por ela e conseguiu. E eu ajudei não só defendendo na Congregação, mas também na fase de montagem e contratação de professores. Mas, como eu já estava com tempo mais que necessário, eu ajudei dizendolhes: olha, eu vou dar toda a força, mas eu não vou trabalhar no curso. Eles não acreditavam, mas desde que o curso foi aprovado, começou a funcionar, eu pedi aposentadoria. Já tinha trinta e tantos anos naquilo e não tinha sentido eu continuar.

Hev: $E$, desde esse início, não foi dada tanta importância ao desenho arquitetônico?

Gastão: Não, não, não! Não se deu um 
valor muito específico ao desenho. E mesmo porque o próprio curso, ele sofreu uma transformação dos fundamentos para frente. Porque os fundamentos eram julgados muito importantes para que os cursos de arquitetos tivessem uma forte presença da tecnologia. Isso quer dizer, das áreas tecnológicas em geral.

Hev: Será que é porque era vinculado à escola de engenharia?

Gastão: Porque era vinculado ao curso de engenharia. Mas esse, o pessoal comandando, ... vamos dizer, esse curso se afastou disso. Passaram muito mais a financiar ou valorizar as áreas humanas, parte de História, do que a parte tecnológica. Começou a haver até uma certa agressão do curso em relação às áreas tecnológicas. Agressão não, mas não aceitavam muito. Eu me lembro que o Walter Nemias (?), que deu aula lá durante um tempo ... Eles não queriam nada. $\mathrm{E}$ a verdade era isso. Quer dizer, estavam naquela época em que achavam que os conhecimentos tecnológicos não tinham a menor importância; o que importava era história e sociologia. Então o curso ficou muito voltado para história, ... um pouco influência do Carlos Martins e desse pessoal, ... Agnaldo ... Achavam que arquitetura era história. Não sei se é, mas é uma desculpa porque o Líseu (?) dizia lá na FAU, naqueles velhos tempos: o pior curso que existia lá era o de projeto; o pior departamento que existia era o de projeto. Todos os outros eram excelentes; História, do Nestor, produtiva, uma beleza. Chegava na hora do desenho de projeto, não tinha nada que prestasse. Ninguém sabia o que fazer, como é que dava o curso, como é que era, ninguém sabia nada. Ou não queriam saber, não tomar conhecimento, ... todos, grandes professores. O único departamento que não funcionava era o de projeto. 0 de história, até hoje,
... eficiência, até hoje. 0 desenho industrial mesmo, razoável. Mas, na questão de projeto nunca foi bom, ... o pessoal não gostava de projetar, eu achava isso: os arquitetos não gostam de projetar; eles projetam no escritório, mas não aqui dentro. Você não conseguia fazer o aluno trabalhar em classe ... Depois trabalhei sete anos na Unesp, em Bauru, a mesma coisa. Na aula de projeto o pessoal fica ... e não sai nada.

Hev: Aqui, os alunos chegando ao $5^{\circ}$ ano, tem boas idéias, um bom diagnóstico de um problema, uma boa proposta e não conseguem colocar no papel. Não sabem desenhar.

Gastão: Não conseguem! E o departamento de projeto era assim, ... o menos estruturado da FAU. Hoje, eu não sei como é que está o departamento, ... mas as áreas outras eram áreas ... Tanto que até hoje você vê, por exemplo, ... o pessoal que hoje está metido com a reitoria, com não sei o que lá, nenhum da área de projeto. Esse pessoal é da área de histórias, áreas alimentadoras do curso, áreas da espinha dorsal do curso. Foi muita moda na sociologia também, naquela época. Aliás, a "culpa" foi do Nestor, também; ele fez sociologia e acabou fazendo sociologia urbana. Mais sociologia urbana do que ...

Hev: Existia o calor das discussões da época, dos anos 60.

Gastão: É. E no tempo dos milicos, isso fica mais latente.

Hev: Eu recebi um e-mail de uma professora de projeto dizendo que muitas escolas particulares, pelo menos da região dela, Minas Gerais, que certas faculdades estão atendendo o currículo mínimo estabelecido pelo MEC de aproximadamente 3500 horas no curso total e que, então, já não tem desenho arquitetônico 
e sugerem que os alunos façam o curso na cidade, em alguma escola técnica, como se faz curso de Word, Excel. Então, vão aprender desenho arquitetônico fora, porque não tem tempo para ensinar dentro da faculdade de arquitetura. E, eu fiquei assim, ... eu acho que devia ensinar em casa, na escola de arquitetura. Mas está acontecendo isso hoje. E eu sinto isso, no $5^{\circ}$ ano, na disciplina de TGI, que eles não sabem representar, não tem expressividade no desenho, não tem um vocabulário mínimo de corte, fachada, como representa, o que é que tem que mostrar no desenho. É uma pena, eu acho que não ...

Gastão: É. Pois é. É porque são caras que não têm uma vocação para desenhista. É, entram no curso porque o próprio curso, ... aquela disciplina de desenho, como chama? ... no vestibular, ... linguagem arquitetônica. A disciplina de linguagem, você vai lá só para fazer besteira. 0 sujeito vai analisar o monte de besteira que o pessoal faz, então não vai selecionar quem desenha. Você acha que o cara que desenha é o que entra nessa disciplina? Muito dificilmente. 0 cara que tem, assim, uma certa criatividade, às vezes, mas não é o desenhista, o que tem uma certa vocação para desenho, ... eu acho. E eu tenho uma história para contar, que vale a pena contar. Eu fui, na FAU USP, nos tempos em que eu estava lá, eu fiz parte do processo de seleção de desenho, da disciplina de desenho. Isso não aconteceu comigo, mas eu fiz parte, posteriormente. Mas, aconteceu em um determinado momento com um colega meu, ... antigamente era desenho mesmo, copiava peças, mas aí resolveram virar a mesa; um dos responsáveis foi o Artigas, que achou que copiar peça não era nada, não sei o quê ... Então, fizeram lá um outro tipo de trabalho, que teria um princípio já da linguagem de arquitetura. Então, estavam analisando uns trabalhos na mesa e ... tinha um trabalho que era absolutamente desproporcional e o pessoal tinha posto de lado. Disseram: este não serve. Aí, o Artigas passou, olhou e disse: escutem, vocês estão pondo de lado este desenho; esse cara é um Doniet (?) Rousseau da vida. É um espontâneo, vocês não estão vendo? E passou (foi aprovado). Esse cara foi meu colega; era um idiota total, absoluto. Chamava-se (X). O cara era a negação da negação de qualquer coisa ligada à desenho de arquitetura. No entanto, entrou como se fosse, ... era o Rousseau do curso porque ele desenhava uma cadeira desse tamanhinho dentro de uma sala deste tamanho. Ele não tinha noção de proporção. Ele sempre foi péssimo. Foi meu colega de classe, ... boa gente e tudo, mas ... acabou o curso não sei como. Foi trabalhar num lugar qualquer aí, ... fazer cálculo ... Eu aprendi a calcular e muita coisa que eu projetei, eu calculei.

Hev: É, a Ângela falou.

Gastão: É. Eu gostava de calcular, sabia? Eu não queria contratar engenheiro para me "importunar". Então, eu fazia as contas lá e calculava. Um pouco de auto-suficiência, vamos dizer. Obras menores, claro; não grandes, não. Então, você vê, não mede. Então, o Artigas disse: esse cara é um Rousseau da vida. Então, entrou aquele cretino lá. Coitado, o sujeito era um coitado. Quando tinha que escolher uma folha, um papel, a pior folha era sempre a dele. Ele desenhava, não sabia desenhar nada.

Hev: Eu participei junto com o Gelson em dois vestibulares do desenho. Esse ano, eu que vou coordenar, pela primeira vez, que o Gelson, há dez anos é ele quem coordena. Você não saberia, assim, ver um critério, 
como avaliar quem seria um bom arquiteto, um bom desenhista.

Gastão: É muito difícil você ter essa visão, mas, infelizmente, o que eu percebi é que, normalmente, os bons desenhistas não entram ... Às vezes o cara é bom desenhista, mas é ruim em matemática, física e em outra bobagem. Então, é cortado. Isso acontece. Não vai ser cortado por causa disso. É, e acho que será sempre uma disciplina maldita neste sentido, porque o cara não tem muita paciência para fazer, para desenhar, para riscar, ... não tem condições. Isso, ... é muito difícil você induzir isso; ... , né? Eu acho que o papo dos professores, dos grandes professores, tem uma visão um pouco distorcida do processo. O Martinelli, por exemplo, achava que a descritiva era importantíssima e então ele dizia: você vê, por exemplo, ninguém é capaz mais de desenhar mais uma escada espiral. Eu dizia: Martinelli, eu sou arquiteto há 500 anos; eu nunca fiz uma escada em espiral na minha vida. Qual a vantagem de você fazer uma escada em espiral? Tem na minha casa, isso ai, certo? ... O que precisa é aprender a fazer as coisas. A descritiva ensina você a fazer uma escada espiral muito bem. E quantas você vai fazer ao longo de sua vida?

Hev: Tem que ser um pouco mais prático, né? Eu vou levar em consideração tudo isso porque eu tendo a exagerar no desenho técnico arquitetônico para que seja suporte para projeto, mas eu preciso saber o que essencial, básico, para que eles peguem o critério e acabem indo por ...

Gastão: Inclusive os engenheiros, eu dei aula em Bauru na Fundação Educacional, eu enfatizava alguns detalhes arquitetônicos que eu achava que os caras não tinham, né, muita dificuldade de ver e de fazer. E uma delas era a escada. Todo mundo, engenheiro não sabe fazer escada. Então, fazia parte do meu curso dar um curso inteiro de escada. Não só da espiral, escada, escada. Como desenvolver uma escada, como projetar uma escada, que altura você precisa, qual a proporção, que mais que ela deve ter e tudo o mais. Então ensinava a fazer escada e telhado. Senão o sujeito vai fazer um projeto, ele não sabe como cobrir aquilo. Depois vai inventar um jeito de cobrir. Ele não associa isso aqui com isso aqui.

Hev: Acho que vou te mostrar uns desenhos e a gente ... e ai eu até queria ver se eu precisar de mais alguma informação, se eu pudia voltar uma outra vez.

Gastão: Ah, sim. Sem problemas.

\section{[Fita 2/2]}

Hev: [...] Na segunda folha, a concordância que deveria aprender já no colegial (ensino médio) e hoje os alunos não tem.

Gastão: É, isso aqui é um desenho geométrico do tempo de colegial. E só completando: um dos grandes problemas é que a universidade assumiu coisas que não são dela. 0 desenho geométrico é um deles. 0 desenho geométrico não é nenhum problema; o problema é que vem lá do ... eles tiraram do colegial; como é que faz?

Hev: Nesse caso eu queria tirar uma dúvida: se eu desenhasse um paisagismo, uma mancha dessa e cotasse tudo, na obra isso é feito com piquete e barbante?

Gastão: Por que não?

Hev: É desse jeito mesmo. 
Gastão: Não vejo maneira melhor do que o fio de nylon, o barbante ou o arame.

Hev: Aqui é um caso que, em desenho técnico, chama-se cotas funcionais, que são as cotas que são necessárias para que efetivamente construa do jeito certo, como a gente quer. Então, isso é um, um arquiteto me ensinou isso: que 0,60 mais 0,80 dá 1,40 , mais 1,60 dá $3,00 \mathrm{~m}$. Só que na obra houve um erro e ficou com $2,90 \mathrm{~m}$. É muito comum aparecer erros na obra, e o proprietário ou o arquiteto encomendou uma pedra importada e vai ter $55 \mathrm{~cm}$. Quando eu coto 0,60 aqui e 1,60 do outro lado, 0 pedreiro tem a liberdade de começar por aqui ou por aqui para deixar o vão da porta. Se ficou com 2,90 e ele começa por aqui, vai ficar com $50 \mathrm{~cm}$ isso e a pedra com $55 \mathrm{~cm}$. Então vai dar um problema aqui na guarnição da porta. Então é o caso de omitir essa cota para que o pedreiro tenha que, necessariamente, começar por aqui.

Gastão: Fazer as importantes, né?

Hev: Isso. Aqui é um caso de que eu estou cotando hidráulicas na parede e aqui é um ralo no chão. $E$ a gente vem empolgado e acaba cotando o ralo que está no chão. Talvez o encanador dê risada da gente porque uma coisa é na parede e outra coisa é no chão e tem que ser cotados separados. Aqui é início de paginação de piso, não é exatamente cotas, né. Aqui, também, é uma omissão dessa cota para que, no edifício, a locação comece como eu quero, a tantos metros do edifício. $\mathrm{E}$, se eu não tenho essa medida correta, se ele começar por aqui ... pode encostar. Isso aqui é uma cota funcional, também, que eu quero que tenha um espaço para eu ... Aqui é uma noção de tomadas de medida sem ter uma trena ou um metro, o palmo da mão, que é $20 \mathrm{~cm}$, mais ou menos, ... para saber quanto tem um azulejo e cotar uma coisa aproximada. O módulo, desenho por módulo. ... Colocando medidas de uma coisa pronta e que não tenha ângulo de $90^{\circ}$. Um metro, ... um metro, ... aqui tem 1,75 , e como transportar isso para o desenho à mão ou no computador. Aqui também é uma cota funcional, de piso acabado a piso acabado e deixa que o engenheiro resolva qual vai ser a espessura da laje. Então, o que interessa é de piso acabado a piso acabado. E aqui, como eu não sei ainda se a estrutura metálica vai ser de 25 de altura ou 40 de altura, eu dei o raio por baixo, aqui no pé-direito, ... se for uma viga muito alta ... Aqui a distribuição de luminárias num ambiente, de não dar cotas absolutas: 1,50, 3,00, $3,00,1,50, \ldots$ porque, se não der a medida lá, é melhor que eu dê um critério para o instalador, para como ele vai distribuir ... Transferir essa responsabilidade para ele e não dar cotas absolutas. Como eu trabalhei muito com projeto executivo, eu sempre tive essa preocupação de procurar ensinar com esses critérios ... Eu acredito que seja uma grande contribuição fazer um manualzinho de cotas e, futuramente, um manual de desenho arquitetônico mais atualizado; isso é que eu penso como contribuição.

Gastão: É, acho que é interessante, sem dúvida nenhuma.

Hev: E, para analisar o desenho arquitetônico ou cotas é que eu estou pesquisando como está sendo o ensino nas escolas de arquitetura, ou que estão deixando de ensinar, ou o que é essencial. É nesse sentido que a minha pesquisa está caminhando. E a Ângela está me orientando nessa direção ... Eu tenho um desenho, ... eu sou da geração que desenhou muito a mão, com "grafos", caneta nanquim e depois eu comecei a desenhar no Autocad ... É, alguma 
coisa que na obra deu errado porque, na prancheta, devia ter cotado.

Gastão: Não, porque quando eu atuava na vida profissional eu não tinha controle dos empreiteiros que eram contratados. Então, o critério do proprietário, às vezes, era o mais barato ou qualquer coisa. Então, eu teria algum problema nesse sentido. Do tipo, por exemplo, fazer alguma viga ao contrário, mas eu peguei fazendo a ferragem ainda, ... fazendo ao contrário do que foi desenhado. E uma escada que ele começou a concretar, eu mandei desmanchar e concretar outra vez. Se fosse seguir aquele desenho, ... ele entendeu mal o meu desenho, se fosse seguir aquele desenho, a escada ia ficar uma porcaria, não ia dar certo. Então eu mandei derrubar abaixo. Mas, aí o caso é de ignorância do próprio empreiteiro. Porque a verdade é o seguinte: a gente trabalha pensando em gente "ilustrada", mas acontece que operário não tem esse nível de conhecimento. Então, os erros que possam surgir são os erros em que o operário não é capaz de ler ou entender o que você fez. Então como eu trabalhava muito naquele período e não existia técnica, eu gostava de fazer planta no executivo em 1:50. Eu achava que dava mais precisão. Eles estavam acostumados a fazer planta, a fazer construção com projeto de prefeitura muito simples. Então, quando dava uma planta na escala $1: 50$, os caras ficavam completamente, ... eram até analfabetos, ... ficavam perdidos. Era muito difícil explicar para eles que era só pegar e dividir pela metade, botar um metro e dividir pela metade o valor. Então existiam problemas por causa da incapacitação da mão-deobra. Muitas vezes, até o telhado. Eles faziam a conta do telhado no sistema antigo. Se você dizia que o telhado tinha inclinação de $20 \%$ eles dobravam o telhado. Por exemplo, eles faziam a conta; eu dizia para eles: eu quero o telhado com $15 \%$. Eles faziam esse $15 \%$, pegavam esse valor e punham aqui.

Hev: Ah! Aumentavam, dobravam.

Gastão: Era o dobro. E não entendiam por que estava errado.

Hev: Aqui o Sr. fazia: avança 10 e sobe 1,5 para tirar graficamente ...

Gastão: Você teria que fazer um pedaço em uma meia-água só e eles faziam na água inteira e ao invés de usar esse valor aqui, eles transferiam esse valor para cá e faziam dobrado. Isso era uma coisa muito comum entre os telhadistas e até hoje: quando quiser um telhado com $30 \%$ você fala em 15 (risos). Se você quer um telhado de $22 \%$ você fala em 11. Isso aconteceu e eles já estavam lá em cima. Eu perguntei: que é que houve aí? O Sr. disse que era $15 \%$ e eu fiz assim. E eu: como é que você fez. E eu disse: tá errado. Eles não queriam entender que estavam errado. Então, muito ... eu tive um pedreiro, por exemplo, um dos melhores pedreiros que eu vi na minha vida, que era analfabeto, não lia planta. Então, tinha que fazer um beiral e você podia medir no teodolito que era perfeito.

Hev: Então, o problema decomunicação é importante também?

Gastão: 0 importante é isso; é que quando você faz isso, você saber com quem você está falando. Se é com um engenheiro, um cara que tem capacitação, ... ou então, o empreiteiro que tenha o mínimo de exigência profissional, senão ... é muito comum não dar certo.

Hev: Quando escadas, ... a escada, sempre que se constrói, ... aqui tem uma viga que vai engastar a escada. Isro tem tem que ser para lá. A pergunta é para esse caso aqui, para 
esse projetinho aqui.

Gastão: Isso é um erro!

Hev: É um erro. E também eu reparei que cada detalhe, ... que tem um patamar de virada, esse degrau aqui não existe; aqui ele é grande, é um patamar e o resto está tudo certo. É que na hora de engastar essa viga que vai pegar debaixo do patamar, ... você precisa de um espaço. Comecei a reparar nas escadas metálicas. Sabe do que eu estou falando?

Gastão: Agora, o desenho do computador é bonito, né?

Hev: Parece ser um processo irreversível.

Gastão: A gente fazia bem assim também, mas esse aqui é mais limpo, né?

Hev: Hoje eu nem ensino mais a prática da caneta nanquim, só o desenho a lápis que é para saber as especificidades do desenho na prancheta, para depois saber usá-las no computador ...

Gastão: Desenho a lápis, né? O "grafos", ... trocava a peninha, ... entupia toda hora, usar a $0.1,0.2$, tudo.

Hev: Mas era super precisa. Era bom.

Gastão: Depois que nasceu aquela de ... (de estilete), ... eu só passei a usar aquela direto.

Hev: A Rotring.

Gastão: É, embora a "grafos", eu sempre a achasse muito mais precisa, mas para mim era mais prático do que o tempo que você ficava fazendo ... com "grafos"... Então, eu usava a Rotring direto. E a graxa ...
Hev: A graxa por trás do vegetal. É, eu usei.

Gastão: Meu desenhista aprendeu bem essa daí.

Hev: Bem, acho que é isso.

Gastão: É, os últimos desenhos que eu fiz, tipo executivo, foi recentemente no computador. Eu não sei esse programa aí, mas minha filha fez a casa de umas pessoas e eu fiz o projeto básico para ela, de prefeitura e aí aquele rapaz, aquele desenhista do departamento ...

Hev: O Donizete.

Gastão: É, o Donizete fez a parte da prefeitura, a coisa toda. Mas, depois, o cliente pediu uma coisa mais detalhada. Então, eu fiz todas as plantas em 1:50 e cortes, justamente para depois fazerem as instalações, aquelas coisas.

Hev: À mão. Foi feito à mão?

Gastão: Fiz à mão ... dentro do possível, na época. Fiz em papel branco, né?

Hev: O professor Hugo Segawa comentou que o Oswaldo Bratke desenhava muito bem, detalhava muito bem e que, ... chega uma hora, que não adianta detalhar mais; que tem que ir para obra e acompanhar a obra porque, às vezes, o pedreiro não vai saber interpretar tudo.

Gastão: É, o Bratke era construtor; ele sabia que era assim. Sabe por que? É mais ou menos o que a Lina (Bo Bardi) fazia. A Lina não fazia detalhe nenhum, ela fazia um desenho básico na obra ...

Hev: Ela ficava no canteiro ...

Gastão: Ela nunca fez um detalhe, 
ao contrário dos detalhistas - tem alguns que já morreram -, o Miguel Forte, ... que detalhava até o último parafuso. O Rino Levi fazia isso. 0 Rino Levi detalhava coisa que já existia pronta. Parafuso, porca, ele detalhava tudo. Formação européia de desenho ... Mas, eu nunca detalhei a este ponto. Havia um que fazia um projeto com duzentas pranchas e, na realidade, faziam assim, ... faziam do jeito que queriam, né? Então, o Bratke foi mais prático, porque era importante, ... até porque a assistência direta na obra era possível. Tinha um escritório no centro, na ... Tinha uns belos desenhistas que faziam os trabalhos para ele. E ele saia por aí, acompanhava as obras e fazia ... Quando tem pouca coisa é melhor fazer assim. Agora, quando você tem um volume muito alto, ... Na casa da minha filha eu fiz assim, ... fiz um desenho básico e ia toda semana lá, quebrava um galho, projetava, fazia uma coisa aqui, aquilo ali. Eu achava que era importante você não errar em certas coisas fundamentais. 0 resto não tem muita importância. Portas, escadas, tudo isso é fundamental; aberturas são uma séria de coisas que você não pode errar ...

Hev: Eu fiquei lembrando do Ramos de Azevedo ou dos arquitetos da época dele, engenheiros-arquitetos, tinham poucas cotas. É por que ele ia muito na obra? É por causa da presença dele.

Gastão: Devia ir bastante.

Hev: Porque, às vezes, aquele desenho que era mostrar para o cliente era o desenho que ia para a obra.

Gastão: É. Mas, era o pessoal que desenhava, aqueles desenhistas italianos, eles é que andavam e acompanhava também. Então, eles ensinavam o pessoal ali direto. Não existia, que eu saiba, esse tipo de projeto executivo mais ...

Hev: Apurado, como é hoje ...

Gastão: Era uma coisa tipo Gaudí. Mas o Gaudí era louco da pedra, então não serve como referência. Ele desenhava tudo, cada coisinha, cada coisa da obra, ... o parafuso, ... era tudo naquele mínimo detalhe. Mas, ele não é um caso muito generalizado.

Hev: Acho que o Rino Levi introduziu um pouco essa coisa do desenho ...

Gastão: Aqui em São Paulo o Rino fazia assim. 0 escritório do Rino era famoso e, por isso, todo aluno gostava de fazer estágio lá e, também, porque era uma belíssima escola de desenho. O Rino era um desses caras muito regrado.

Hev: Já apareceu muitas monografias sobre ele, ... mestrados ...

Gastão: É ... Ele é realmente ... O Rino dava aula fazendo listinha, quer dizer, ele fazia organograma. Ensinava a fazer organograma de obra. Ele achava que o organograma era a base de tudo. Depois, fazia o projeto. Era o homem do organograma.

Hev: Tem o livro do Victor Dubugras, que é de 1997, do Nestor Goulart ... O Dubugras tinha um nível de detalhamento de cotas muito bom. É de 1903.

Gastão: Mas era de uma linha de trabalho em que isso era bastante exigível, vamos dizer assim.

Hev: Ele era um bom aquarelista.

Gastão: E é a linha dos espanhóis, ... Argentina. $O$ ensino de arquitetura na Argentina é exatamente o ensino de arquitetura na Espanha e o ensino de 
arquitetura na Espanha, ... não existe arquiteto. Não existe o engenheiro civil. 0 arquiteto existe. 0 arquiteto é o engenheiro civil também. Tanto que a primeira escola de engenharia civil do mundo, depois da França, foi na Espanha. Veio a escola de Ponts et Chausses, ... poucos anos depois a Espanha abriu a escola espanhola que até hoje existe. Então o engenheiro civil no sentido que nós temos aqui não tem na Argentina e nem na Espanha. Então, o arquiteto na Espanha, como na Argentina, é muito preocupado com esse tipo de representação.

Hev: É, acho que é por causa disso porque eu vi um desenho de um portal, ... tudo cotado, exaustivamente cotado.

Gastão: É, porque se queria que fosse realizado exatamente o que ele imaginou, tinha que ser assim mesmo, não tinha outro jeito, ... vindo do próprio controle. Tinha que estar lá e ensinar os caras a fazerem direito. Agora, o negócio do Gaudí, por exemplo, até hoje eu não entendo como é que ... ele imaginou certas coisas e que na realidade não era um negócio desvairado, era tudo geometria descritiva que ele aplicava, as soluções e tudo. Aquela famosa lá, La Pedrera, aquela construção de esquina do Passeio de Gracia que é um conjunto de apartamentos ... Eles tem uma visitação só no forro, na parte de cobertura. A parte de cobertura é uma selva de tijolo, ... O negócio lá é alucinante. Como é que pode se preocupar a esse nível, ... quando o próprio prédio já tem 500 detalhes: aquelas grades, aquilo tudo, aquele interior ... E aí, chegase na cobertura, você fica bobo.

Hev: Será que o Frank Lloyd Wrigth detalhava bastante também?

Gastão: Provavelmente. Os desenhos dele eram desenhos típicos dos arquitetos americanos porque ele trabalhou com aquele pessoal de Chicago, ... Sullivan ... E eles tem um nível de desenho muito desenvolvido, principalmente os desenhos em perspectiva dele eram muito bonitos. Eles tinham uma linguagem própria, uma linguagem que lembra muito 0 [...], ... que é do Mackintosh. Então, vizinhos, vamos dizer. Só que o Mackintosh morreu com 30 e poucos anos, 40 anos no máximo e o Wrigth morreu com 90 anos. Mackintosh trabalhou num país onde havia uma certa recessão econômica já e, depois, ele entrou na Escócia, num período, porém, em que a Inglaterra já estava em decadência. Os EUA era o brilho do mundo naquela ocasião. Então o Wrigth teve muito mais chance. Mas, no fundo, o dois são uma espécie de Art Nouveau. [...] Os móveis até hoje existem para vender, tem a grife Mackintosh. Os caras vendem os móveis, essas coisas todas. A cadeira está no museu. No Museu de Glasgow tem lá uma construção que é, vamos dizer, seria um pedaço da casa de Mackintosh, com as cadeiras e os móveis, os armários, as camas. E tem uma casa que também é um monumento, também que foi tombada, que fica mais afastada de Glasgow, em um lugar chamado Helensburgh, ... é a casa da colina, uma casa que foi feita ... e que hoje é visitação pública. Tem uns móveis, tudo mobiliado, aquelas coisas dele, ... estranhas. No fundo ele era um designer, ele e a mulher, o grupo dele. Mas ele foi para a Europa, para o continente e morreu lá em torno de 1928, morreu cedo, morreu mal, coitado. Agora, a linguagem dele é muito parecida com a imagem de Wrigth. São muito vizinhos, muito parentes, muito parecidos, muito próximos. Eu gosto do Mackintosh.

Hev: Eu fico pensando, como um arquiteto pode ter trabalhado tanto? 0 Wrigth, por exemplo. São tantos 
detalhes, ... motivos decorativos ... Um agrande capacidade de trabalho ... É por que ele devia ter uma grande equipe ...

Gastão: Ele tinha, né? O Wrigth tinha uma escola, vamos dizer entre aspas por que ele tinha seguidores, pessoal ia lá trabalhar com ele, fazia de tudo para ele. Ele era meio fisiocrata, ... ele achava que a Terra era o núcleo de tudo; então, o pessoal que ia lá trabalhar com ele tinha que tratar de gado, fazer horta, cuidar do campo e ainda tocar música. Ele dava preferência para quem era músico. Ele tinha uma orquestra e tinha os que tocavam. Tinha órgão, tinha piano, tinha cravo, tinha tudo lá e ... dava preferência e cobrava dos caras. Existe a Fundação, ... mas ele cobrava. Existem dois ou três do Brasil que andaram por lá. O Miguel Fortes eu acho que foi um deles. Foi discípulo ... O outro foi o José ... que já morreu, ... andou por lá fazendo um aprendizado. Ele obrigava o pessoal a fazer de tudo. Era um ditador. Então, tinha mão de obra barata. Então, até para construir tinha gente. Tinha muita coisa que eles construíram. Lembro-me de uma piada que saiu no jornal, uma história que é uma piada, mas é uma piada verídica. Um pessoal que o Wrigth fez a casa, era uma casa meio alta assim, tinha umas cercas enormes, que não foi feita com a madeira que o Wrigth queria. Uma noite os caras estavam lá e, de repente, viram um monte de carro subindo aquela ladeira, aquela colina e chegava o Writgh com 20, 30 carros ... Disse: derruba isso aqui! E os caras: que é que houve? E ele: isto está errado ... eu vou fazer isso por minha conta. Derrubaram a cerca inteira e fizeram do jeito que ele queria.

Hev: E é verdade isso?

Gastão: É verdade. Foi contado pelo casal que tinha a casa. ... Mas, são histórias desses grandes gênios, né?

[Fim do lado A, início do lado B]

Gastão: Aí entra a ... da ponte, né? É meio ponte do Rio ... , 1759. A primeira ponte do mundo feita de ferro, ..., a fundição ...

Hev: É, Mackintosh é meio Art Nouveau?

Gastão: Mackintosh, ele corresponde ao Art Nouveau; ... mas ele é contemporâneo do Wrigth. É praticamente da mesma época, tem a diferença de nascimento, ... só que ele morreu cedo e ele morou em um país que não havia aquele "boom" de construção, aquele brilho de coisas como nos EUA e ficou em desvantagem nesse sentido. Foi desfavorecido nesse aspecto.

Hev: Mas o que ele fez foi bem feito, foi genial.

Gastão: É, a grande obra dele foi a escola de arte de Glasgow. Como arquiteto ele não tem muitas coisas, tem mais como decorador, como designer. Ele e a mulher, que também era desenhista, tinham um atelier amplo de design, faziam móveis, faziam confecção. Na arquitetura ele fez, ... conta-se nos dedos, ... poucos interiores como o famoso salão do chá, essa escola que está lá, essas casas que estão ... e só isso.

Hev: Ele também criou um tipo de letra ... que se chama Mackintosh.

Gastão: É, que o Wrigth usou muito em uma fase conhecida, ... uma coisa parecida. Estilo Mackintosh. E na Escócia é uma veneração. Existe lojas Mackintosh que tem os desenhos dele ...

(Transcrição: Marcele C. Silveira) 
Entrevista com José Mário Nogueira de Carvalho Jr.

\begin{abstract}
Arquiteto e Professor José Mário Nogueira de Carvalho Jr. Data: 10.01.2003 Local: Escritório - Rua São Paulo, 597 São Carlos-SP
\end{abstract}

A entrevista se desenvolveu com base em desenhos técnicos arquitetônicos elaborados pelo autor, que tinha a cotagem como temática; e com desenhos executivos de arquitetura que o arquiteto Zé Mário mostrou de seu escritório.

Hev: Prof. José Mário, viemos conversar com o senhor, pela importância como profissional arquiteto atuante e também como professor na área de desenho e projeto.

\section{[...]}

Zé Mário: Eu acho que cota é parte de um sistema que a gente poderia chamar de sistema de informações do projeto. E eu acho que o sistema de informações do projeto está ligado à questão da leitura: você têm determinadas informações e elas devem constar no momento de leitura daquela folha; você têm outras informações que pertencem à outros momentos de leitura. Então, eu acho que na primeira folha, você deve, vamos dizer assim, dar o maior número de informações a respeito daquela idéia, daqueles desenhos, de tal forma, que você não caia num negócio que a gente, antigamente, chamava "redundância", isto é, poderíamos entender como excesso repetitivo de informações. Eu acho que a redundância é, muitas vezes, confundida com repetição de informações, como por exemplo, repetição de uma cota. Muitas vezes, é necessário você repetir uma cota como um recurso. Agora, quando a gente utiliza esse recurso ou quando você percebe que está havendo a questão da redundância no nível de informações das cotas, é só com a prática. E, eu acho que, principalmente, ela deve estar relacionada com como é visto isso na obra, porque você desenha o projeto para outro construir. Isso está na separação técnica do trabalho. A arquitetura foi dividida em concepção e construção, nem sempre quem projeta é o mesmo que constrói. $\mathrm{Na}$ maioria dos casos não é. Então, você desenha para que? Você desenha para que uma pessoa possa construir aquela tua idéia. Numa folha você coloca todas as informações necessárias à construção daquele objeto, de tal forma que a pessoa que vai ler receba o máximo de informações possíveis sobre aquilo lá e que ela tenha um entendimento daquele desenho da forma mais simples possível. Então, se você não dá informações, se falta informações, é um problema para a pessoa entender e, se você têm informações além do necessário, você cria obstáculos para que a pessoa entenda o mais rapidamente possível aquele projeto. Então, eu acho que a questão da cota está ligada à isso aí. Você têm, por exemplo, cotas... você pega um corte na escala 1:50 e cota a altura de um tampo, de cuba de banheiro ou de cozinha, e ele não vai precisar daquela cota naquela hora, ele vai precisar das cotas gerais da...

Hev: da construção civil...

Zé Mário: É ... não, não da construção, mas da alvenaria. E as cotas de alvenaria, por exemplo, nesse caso, devem estar relacionadas com as cotas de estruturas. Como? Através de eixos ou de seja lá o que for... Nesse caso, ocorre uma questão. Por exemplo, a gente cota uma parede com $15 \mathrm{~cm}$, ela vai ter 15 , ela 
poderá ter 14 e meio, 15 e meio, já vi parede até com 16, e isso varia. Então, um sistema de cotas que seria, talvez, o melhor, é o de cotas por eixos. Mas, você não tem, em obra, uma cultura de leitura a partir das cotas de eixos. Eu já fiz uma experiência, uma vez, e dei com os burros n'água. Por que? Porque o pessoal simplesmente somou aquela espessura e aquele eixo. Por que? Porque não entendia... ele entendia que a parede era de 15, então ele somou, se estava cotado de eixo a eixo, ele somou mais os $15 .$. .

Hev: acumulou, e foi acumulando...

Zé Mário: É, isso deu problemas, inclusive: tem uma casa na qual ele acertou, em certos pontos, depois ele esqueceu, o banheiro aumentou $40 \mathrm{~cm}$... Por que? Porque tinha cotas de eixo. Então, eu acho que o ideal seria essa cota de eixo, mas nós não temos uma cultura de leitura através da cota de eixo.

Hev: Tem um caso aqui de uma cota que é pela alvenaria a osso, num desenho que está aqui ...

Zé Mário: É, mas também o tijolo varia, certo? 0 tijolo varia ...

Hev: Na verdade, talvez um desenho preliminar porque na obra sai tudo diferente...

Zé Mário: Não necessariamente ... Hoje, por exemplo, com o bloco que é feito industrialmente você tem uma proximidade maior. Agora, ninguém garante que a argamassa de revestimento tenha $1 \mathrm{~cm}$ e meio ou $2 \mathrm{~cm}$... ninguém garante isso. Hoje tem o gesso com meio centímetro. Você vai cotar meio centímetro? Não vai. Eu não coto, eu acho bobagem... eu escrevo: "revestimento de gesso" e coloco $15 \mathrm{~cm}$. Não vai passar dos 15 , pode até passar, principalmente, quando tem azulejo do outro lado e eu vou usar argamassa normal ali. Então eu acho que os sistema de cotas, em primeiro lugar, depende muito de bom senso, depende muito de uma prática de leitura de projeto, de como esse projeto vai ser lido na obra. Depende de uma questão: vai ser lido por quem? É um engenheiro? É um mestre de obras? Eu vejo diferença nisso, não que o mestre de obras não saiba ler, pelo contrário, acho que sabe ler até melhor que a gente, mas ele tem uma maneira de ler, ele tem uma cultura de leitura de projetos. Então, é fundamental a gente saber quem vai ler esse projeto e saber em que momento vai ser lida aquela informação, porque ele vai precisar daquela cota naquele momento. Você começa, por exemplo, com cotas de banheiro. Não adianta, na cota 1:50, ficar cotando bacia. Ele não vai precisar daquela cota naquele momento. Lá, quando você faz aquelas ampliações de banheiro, na escala 1:20, então você cota os pontos que decidem e umas coisas mais. Aí, sempre, nesse caso, é muito importante você dar uma relação, uma referência. A referência, normalmente, é a parede. Por exemplo, cotas de caixilho, eu acho essa cota aqui, dispensável... eu não preciso dessa cota, eu tenho essa. Tenho essa, mais a cota do caixilho. Então eu já sei: fica a tanto dessa parede. Essa daqui, para mim, seria um caso de redundância. Da mesma forma esta cota, ou esta... Então, eu acho que, em determinadas situações, é que o bom senso predomina... isso aqui, da maneira como você indicou aqui, está perfeito: você tem uma cota geral, uma parcial, e as outras parciais aqui. $E$, esta daqui, inclusive, eu até acho que seria importante ela não estar aqui, junto com essas; eu colocaria ela aqui dentro.

Hev: É, como eu estou sugerindo aqui. 
Zé Mário: Exatamente. Mas, essa daqui, eu jogaria para fora. Eu tento separar cota de alvenaria e de caixilho. Eu sempre procuro separar isso. Muitas vezes sai daqui do escritório uma cota que acontece dessa forma. Mas, eu sempre procuro separar porque eu acho que são dois momentos distintos. A cota de alvenaria ele vai usar num momento e, a cota para deixar a abertura do caixilho, ele vai usá-la não naquele momento. Então, eu separo: eu jogo esta para fora, e deixo só esta aqui, olha, 30 e 70. Mesma coisa, uma cota de corte. Muitas vezes, o 70, eu prefiro usar a tabela de caixilhos para não ficar concentração muito grande de cotas; eu só jogo 30 aqui, 50 aqui, 50 aqui. Na realidade, a gente trabalha, mais ou menos, assim, olha: esse aqui, inclusive, já foi alterado esse sistema de cotas aqui, porque esse projeto é muito antigo. A gente passa cotas em cima de desenho.

Hev: Mas, eu sou partidário disso porque, às vezes, fica tão distante...

Zé Mário: Por exemplo, cotas de vagas de garagem... eu não utilizo linhas de cota. Mas, nas cota de alvenaria, utilizo as linhas de cota, no caso de projeto executivo. É aquela questão sobre a qual eu te falei, ela aparece como reforço. Nesse projeto a gente já mudou um pouco o sistema de cotagem. Usar sempre cotas horizontais em planos horizontais. Em planos verticais a gente procura sempre usar cotas verticais; com algumas exceções. Exceção qual é? Depende do tipo de informação que precisa passar. Por exemplo, tem certas coisas que a gente procura não cotar... eu vi um desenho seu aqui...

Hev: Acho que é um beiral, não é? Aqui!
Zé Mário: É. Isso aqui, por exemplo, a gente não cota. O beiral, a gente procura sempre por cota em planta e, isso aqui, é cotado no detalhamento.

Hev: Esse aqui é um desenho preparativo do executivo que eu desenhei para passar para o CAD, ele têm as informações necessárias para ele desenhar.

Zé Mário: Perfeito... mas o resto, acho que é questão padrão mesmo. E para mim, é fundamental a questão de quem vai ler, de que tipo de informação vai passar e do momento da leitura.

Hev: Eu queria tirar uma dúvida... você conhece a Maria Ângela Bortolucci, que é minha orientadora?

Zé Mário: Não...

Hev: Se a gente optar por fazer esse "tiquezinho", a $45^{\circ}$, quando for fazê-lo na vertical, ele - esse aqui está errado porque a cota está sobre a linha, e não aqui na horizontal -, o "tique", tem que ser nesse sentido? Porque eu colocava sempre de qualquer forma e ela que me advertiu: "olha, vê se você encontra literatura sobre isso". E eu não achei...

Zé Mário: Olha, eu acho que isso pode ser um traço ou pode ser a bolinha ou pode ser o ponto... Um monte de coisas eu posso indicar, pode até ser... eu não sei, eu nunca vi...

Hev: Parece que é no sentido da leitura, de escrever... se eu escrevi assim e ele está caindo para a direita, na hora que eu vou escrever assim, ele cai para a esquerda.

Zé Mário: Como caindo para a direita? 
Hev: Assim, olha, meu sentido de escrita é para lá, então, na hora que eu estou escrevendo, sempre está caindo para a direita...

Zé Mário: Bom, mas aqui caiu para a direita...

Hev: Não... caindo para a direita, para lá...

Zé Mário: Não, mas esse aqui, olha, não está caindo para a direita?

Hev: Não... esse aqui está caindo para a esquerda. Rotacionou para a esquerda.

Zé Mário: Não, eu não entendo muito disso, não...

Hev: Não... eu também fiquei... depois eu fui ver no CAD, e o CAD faz desse jeito: ele inverte, quando é na vertical e eu nunca tinha reparado nisso.

Zé Mário: Aqui o que é que a gente usa? É ponto, acho que é ponto... é ponto.

Hev: É... você usa ponto, então, não teria problema...

Zé Mário: Eu não vejo tanto problema nisso aí, se é para a esquerda, se é para a direita...

Hev: Não... é que, como isso vai estar no manual, tem que estar o mais correto possível.

Zé Mário: Eu sei que a leitura da gente é da esquerda para a direita.

Hev: Isso. Aqui eu queria mostrar uma coisa: durante o exercício, em projeto ainda, a gente materializa um ponto e faz um arco, uma parede de um auditório, por exemplo, e na obra $(. .$.$) aqui já é o vizinho$ construído; então, não tem como fazer isso aqui com barbante, sei lá... e teria que fazer um sistema de cotas desse tipo. Eu reparo que as pessoas cotam assim e pronto, e manda para a obra...

Zé Mário: Tá errado. Na obra, eles não conseguem fazer assim...

Hev: O que eu estou chamando de cotas funcionais que eu já vi em desenho técnico...

Zé Mário: Tinha um aí, nós temos até um outro aqui, mas não está aqui, no qual a gente usou isso aí, inclusive...

Hev: E aqui, a gente está cotando a hidráulica de parede, aí começa a cotar na hidráulica, que é um ralo no chão; está mudando de plano...

Zé Mário: Normalmente, essa cota eu evito.

Hev: Começa de lá e começa daqui?

Zé Mário: Exatamente. Essa cota eu evito e essa cota aqui, também, daqui até aqui, eu evito, porque isso aqui, normalmente, é eixo disso. Então eu coto isso aqui. E, essa cota aqui eu sempre separo disso. 0 chuveiro sempre que (...) a não ser que ele saia do eixo, mas eu procuro até não cotar porque ele é eixo.

Hev: Mas o box não vai estar lá instalado ainda...

Zé Mário: Não, eu sei. Mas, mas vai ter um rebaixo do piso. Ele já sabe onde é o rebaixo do piso, então para deixar o rebaixo do piso o que eu faço: eu já marco esta cota, daqui até aqui, não do box, a do rebaixo do piso é que eu estou marcando. Feito o rebaixo do piso, eu sei que isto aqui é eixo (do chuveiro), a não ser que você a coloque numa outra situação. $E$, eu sempre procuro esta cota perfeita, muitas vezes eu até faço assim: daqui até aqui, tanto; 
daqui até aqui, tanto. Coloco duas linhas de cota. Muitas vezes já fiz isso.

Hev: Por que?

Zé Mário: Porque, muitas vezes, isso daqui, dependendo do tipo de cuba ou alguma coisa assim, pode haver uma certa confusão se ele juntar as duas coisas. Então, em algumas situações a gente coloca assim, em outras situações a gente coloca separado. Procura não relacionar isto com isto. Isso daqui a gente deixa pelo eixo, isso daqui a gente marca, simplesmente, um tanto para cá e ela tem nos dois sentidos.

Hev: Aqui, nós pensamos assim: essa cota do piso acabado que eu calculei e o fabricante pensa até a fundação. Falando de uma mesma coisa, a mesma peça, a gente sempre pensa do piso acabado para cima. É que eu estive acompanhando uma obra na USP: não, tem que ter tanto, e o fabricante: não, mas e a partir da fundação? Porque ele era o fabricante; para ele interessava a peça inteira, que é debaixo da terra.

Zé Mário: Nesse caso, eu não faço isso.

Hev: Cotar lá embaixo, mesmo na arquitetura?

Zé Mário: Tanto é que a gente tem norma. Antigamente eu cotava, hoje eu não coto mais. Por exemplo, toda linha de baldrame, $30 \mathrm{~cm}$ abaixo do piso acabado, certo?

Hev: Certo. Vai passar tubulações de esgoto ...

Zé Mário: Eu peço isso... Teve um problema agora, o rapaz não me colocou, mas aí a empreiteira disse que vai passar por baixo. Mas, antigamente eu cotava, hoje eu não coto mais. Por exemplo, esta cota, eu não usaria nunca esta cota. É muito próxima desta; eu faria: esta aqui e esta, para cotar a porta.

Hev: É que eu contei uma história aqui para exemplificar isso aqui...: na obra houve um erro e aqui deu 2,93, por exemplo, e eu já encomendei essa peça, esse tampo, então, eu estou dizendo que seria bom evitar esta cota para que não desse problema de a guarnição da porta ficar sobre a bancada.

Zé Mário: Ah! Mas eu posso ter o problema também de cotas muito próximas e criar dois problemas.

Hev: Ah! Visual! Problema de leitura! Entendi.

Zé Mário: Exatamente. Essa é mais usual. Por isso é que eu te falei, prefiro dar esta cota e esta. Outra coisa, sempre esta peça (...)

Hev: Se encomendar uma peça importada que vai demorar para chegar...

Zé Mário: Mas aí, simplesmente, se deu erro aqui, chega-se a porta para cá.

Hev: Tá. Nesse caso é mais fácil trocar a porta.

Zé Mário: Motivo: porque essa confusão de leitura pode ocorrer em obra.

Hev: É, isso é interessante.

Zé Mário: Aliás, existe uma crítica: foi feito um trabalho que a revista Veja publicou, há uns 4 anos atrás, comparando o projeto brasileiro com o projeto americano...

Hev: Puxa! Eu precisava dar uma olhada nessa revista...

Zé Mário: Foi feita uma pesquisa em várias áreas... Você tinha aqui 
um projeto, se não me engano, americano...

Hev: É, eu tenho um projeto cotado em polegada. Ele está cotado pela alvenaria a osso e pelo eixo das janelas.

Zé Mário: Não, então, olha o nível... Não, sem discussão isso daqui, olha nível de informação que tem, certo! O europeu também é assim, então, a crítica que eles faziam era que o projeto brasileiro não tinha informações suficientes, que ele tinha uma qualidade de informação que dava problemas de leitura em obra.

Hev: O brasileiro?

Zé Mário: 0 brasileiro. 0 americano, não. Inclusive, ele faz uma comparação da mão-de-obra que tinha lá e a mão-de-obra que tem no Brasil. Ele disse: em certas situações, ela não é muito diferente, porque lá, a maior parque eram mexicanos que não liam em inglês. Mas, o projeto é muito bem detalhado, está relacionado a detalhe, nível de informação de cotas muito grande, outros tipos de informação também muito grande e se utiliza muito o "script", que nós utilizamos pouco. Tinha uma pessoa que debulhava aquilo lá e já soltava rapidamente. $E$ não só isso. Eles têm uma série de coisas que são padronizadas. Isso daí facilitava muito a construção. Nós não temos aqui.

Hev: Eu fico pensando: os americanos e europeus. Na Europa é frio então eles têm que ter calefação e umas coisas que fazem parte de detalhes de corte de parede dupla, com isolante, e aqueles detalhes milimétricos. Esse controle brasileiro é diferente: começando do colonial, com taipa...

Zé Mário: Mas, ... agora já acabou, ... mas a tradição que a gente tinha era construir com planta de prefeitura.

Hev: É verdade...

Zé Mário: Por que? Porque tínhamos excelentes mestres de obras. É essa a coisa: excelentes mestres de obras. Agora, hoje, está mudando a coisa. [...] Eu acho que aqui falta uma cota, por exemplo, esse eixo aqui é fundamental, senão ele não consegue colocar isso aqui.

Hev: É que, aqui eu estou querendo ressaltar que tem que deixar os $4 \mathrm{~cm}$.

Zé Mário: Muito bem, mas, senão ele não consegue colocar isso aqui.

Hev: Como não? 04 não seria suficiente?

Zé Mário: Não, não... o 4 é o suficiente. Esta peça aqui, existem situações que ela vem em duas.

Hev: Como?

Zé Mário: Isso aqui não é soldado diretamente, é soldado depois, é soldado em obra. Já tive situações dessas.

Hev: Ah! Entendi.

Zé Mário: Antes de saber se ela vai ser soldada em obra ou não. Então, o que é que eu faço? Normalmente eu dou essa cota. Eu sei que isso aqui são 2 polegadas, eu sei que isso aqui vai dar $4 \mathrm{~cm}$. É outra maneira de você dar a mesma cota; e isso daqui já vem separado.

Hev: Na verdade, é (o desenho) uma coisa diferente da obra.

Zé Mário: Não... eu acho que o projeto fica muito longe da questão da produção... Na arquitetura, o desenho, eu acho uma sacanagem. 
Sacanagem porque ela divide 0 objeto. Isso é, melhor controle do operário, né? Você tem que juntar as partes que o projeto separa. Tanto é que o desenho que utilizamos é baseado no sistema de projeções. Isto estava guardado no ministério de guerra francês. Você sabe disso. Foi guardado no ministério da guerra francês que era usado para usar projeções do exército de Napoleão. Foi a primeira utilização que foi dada ao sistema de projeções.

Hev: Até que nível deveria ser ensinado na escola?

Zé Mário: (risos) Não... Eu acho absurdo dar desenho na escola. Eu tive no ginásio.

Hev: É, acho que na FAU não tinha...

\section{Zé Mário: Na FAU não tinha.}

Hev: É, mas eles têm que aprender aonde, então?

Zé Mário: No ginásio! Se você aprender o básico no ginásio, se você souber o sistema de projeções no ginásio, certo, quando você chega na escola, rapidamente, você aprende. Se você puser uma disciplina lá, de projeto, rapidamente, você aprende. É muito fácil.

Hev: É, a convenção é simples... não é complicada.

Zé Mário: A convenção é simples. Se você tiver a convenção no ginásio, lá na frente, uma disciplina de projeto ensina isso...

Hev: Nem todos vão sair do ginásio com essa preparação para fazer arquitetura...

Zé Mário: Bom, mas aí, é uma questão... então, vamos dizer, o ginásio é deficiente. Então, pelo fato de o ginásio ser deficiente, a gente perde, muitas vezes, dois semestres dando essa disciplina. Eu acho isso.

Hev: Eu acho que deveria ser ensinado na escola de arquitetura.

Zé Mário: Bom, eu acho que deveria ser ensinado lá (no ginásio). 0 básico, você tendo o básico... o que é? é uma linguagem! Da mesma maneira que você aprende o português você vai aprender isso daí. Ninguém está dizendo que tem de ser dado o desenho de arquitetura, mas acho que tem que saber o sistema de projeções. Como é que funciona o sistema de projeções. Como é que você desenha isso aqui, olha: como é que você desenha plantas, vista de cima, elevações, como é que eu desenho? Você sabendo isso, você sabe, o resto você aprende rapidamente, porque você aprendeu a linguagem do desenho. 0 problema é que o pessoal chega e não sabe nada! Não sabe nada, nada, nada! Agora, eu te faço uma outra pergunta: em que ano é dado desenho? Primeiro ano. Não é uma linguagem? Tá. Como é que você vai ensinar para eles que isso daqui tem $15 \mathrm{~cm}$ ? Isso é uma parede. Como é que é a parede? Ele tem que saber como é que é parede para ele poder dar uma traço, dois traços e perceber o que é que significa aqueles dois traços. Eu estou dando desenho agora. De tanto reclamar que ninguém sabia nada, eu estou dando desenho. Eu vou lá e dou aula de construção.

Hev: É, eu tenho feito isso. Eu mostro um pilar.. o que é...

Zé Mário: É bobagem... Se você puder, leve-os na obra. Antigamente se levava a turma na obra; hoje eu chego lá mostro; é assim, assim, assim...

Hev: Para saberem o que estão representando, né? 
Zé Mário: É lógico, senão não adianta!...

Hev: É, eu tenho feito algo parecido. Tenho fotografado obra...

Zé Mário: É. Eu acho que a melhor maneira do pessoal aprender é levar em obra. Então, essa é a questão.

Hev: Eu acho que gente tem que chegar numa fórmula ... Existe uma deficiência no ensino médio, que deveria ensinar projeção. Chegar numa fórmula de, rapidamente, inteirar isso ao aluno porque, às vezes, vão para o TGI e não sabem desenhar direito. Eu estou tentando, eu sou professor de desenho e estou tentando apagar esse incêndio aí no departamento de arquitetura. Mas acho que não cheguei numa fórmula adequada porque tenho que dividir a disciplina com desenho livre, também.

Zé Mário: Desenho livre eu acho importante. Tem que saber desenhar direitinho. Eu faço um desenho aqui, e passo para elas (arquitetas e estagiárias), elas querem me bater. Entender que o projeto é idéia e o desenho nada mais é que uma forma de você aprofundar aquela idéia. Esse desenho à mão livre, eu uso muito esse desenho para isso.

Hev: Elas se queixam de que?

Zé Mário: Não... porque o meu desenho é pior que o do Corbu, certo?

Hev: Ah!... (risos)

Zé Mário: Mas eu acho que é esse desenho que tem que representar idéias, que tem que ... o desenho como um processo investigativo. $E$ isso eu acho importante. Isso acho fundamental. Acho que esse desenho aliado a dobrar papel, a gente usava muito, antigamente, dobrar papel, pegava o papelão, dobrava, via a coisa espacial como é que estava acontecendo (...) a gente estudava coisa por coisa do projeto e isso eu acho importante. Agora, esse desenho aqui, o meu também... por que? Porque na escola você não tem, não é que você não aprende... você não tem prática disso aqui. É a mesma questão: o pessoal não liga para estrutura, claro que não liga. Se em projeto se fala em estrutura e em estrutura não se fala em arquitetura... Se você pegar o dicionário, arquitetura e estrutura são sinônimos ...

Hev: Então isso daqui é uma linguagem e tem que ser passada rapidamente...

Zé Mário: Eu acho que as disciplinas que tem... como é que você aprende a representar. Agora tem certas coisas que não adianta você ensinar na escola porque vai ser perder. Eu acho que certas coisas de projeto, de certas informações que você tem que passar, eu acho que isso só a prática é que vai te dar... eu aprendi muito e, talvez, eu tenha aprendido mais rapidamente porque eu fiz estágio desde o primeiro ano. Eu acabei fazendo arquitetura em 6 anos; eu fiz uma ano de maquetes e eu participei da Bienal e foi muito importante para mim. Então eu perdi um pouco de tempo, mas eu já sabia desse ponto ... Então, rapidamente, eu peguei... e essa parte de projeções eu tirava de letra; eu tive um excelente professor no ginásio que ensinava isso aí, inclusive, dava desenho à mão livre para a gente. Um cara muito bom! E, depois, eu passei para a FAU, prestei vestibular novamente, passei para a FAU e eu trabalhei os 5 anos da FAU. Então, quando eu ia desenhar projeto eu tirava de letra. E, ao mesmo tempo, no terceiro ano, eu comecei a ... [viramos a fita] ...Engraçado, eu tive aula com o Décio (?) que dava a parte de estruturas para a 
gente lá e ele era tempo integral. $\mathrm{Na}$ terceira aula eu saí da aula, 5 minutos e saí. Por que? Porque era teórico demais. Fomos fazer a tal da dependência. A gente teve que fazer o curso inteirinho, a gente não teve nem presença. A gente foi fazer com o Mário Franco: totalmente diferente ...

Hev: Ou seja, quem tinha um pé na escola e um pé no escritório...

Zé Mário: Não, não é... Aquele que tinha condição de levar para dentro da sala de aula experiência... Por exemplo, eu tive aula de concreto com o Figueiredo Ferraz, eu acho que ele deu 2 ou 3 aulas e depois foi para a prefeitura de São Paulo; entrou no lugar dele o seu assistente na FAU e no escritório, o Margarido. Ele deu aula de concreto e a gente conseguia aprender. Por que? Porque ele levava para discutir com a gente as coisas que estavam ocorrendo no escritório e eram coisas fantásticas! Pilar cintado, pilar desse jeito, pilar assim, como é que a gente faz, como é que gente resolve assim. Olha, esse a gente resolveu assim! ... Então, coisas que não eram simplesmente ir lá e dar o que estava no livro. Ele deu para a gente o que não estava no livro. Então, não sei, eu acho que é um pouco diferente. Eu acho que essa questão, essa ojeriza que a gente tem pela construção, ojeriza que a gente tem daquela parte de estruturas, isso é coisa de engenheiro... aliás, isso (...) pela escola, quando deveria ser o contrário, essa coisa de engenheiro, acabou com o arquiteto, tanto é que hoje a gente já é mais considerado, mas na época, um pouco antes, na minha época, o pessoal que se formava não era considerado. Eu já ouvi gente falar: Você é arquiteto, ... mas você tem diploma? Um diploma não significa nada, mas era a visão que se tinha... O Artigas fala isso... 0 Artigas... o que era o arquiteto? Não era considerado nada... então, eu acho que essa desconsideração, aliás, existe um pouco hoje também. $\mathrm{Na}$ minha época chamavam a gente de poeta: você vivia lá, fora da realidade... Eu acho que essas coisas ... vai ter que uma hora mudar, né?

Hev: É eu me formei, trabalhei 15 anos em São Paulo e agora comecei a dar aula...

Zé Mário: Arquitetura? (risos) Quando eu falo assim (...) é uma diferença assim: eu tive aula de história da arte que eram critérios para você analisar obras, quadro, obra de arquitetura, tinha critérios... depois eles vão lá e mandam você decorar capitel... Ah! Bobagem! Acho que tem que mudar isso aí. Eu acho que tem que aprofundar mais as coisas, conhecer mais (...)... Você pega o pessoal hoje (...) Parecia que sabia de alguma coisa... (...) se sabe só sabe o nome... o buraco vai ser grande... ou senão a gente vai acabar ganhando pelo número. Porque parece que o número de arquitetos que se formam hoje...

Hev: É, tem 140 escolas no Brasil ...

Zé Mário: Exatamente. Na minha época não tinha tanta escola. Tinha a FAU de um lado e o Mackenzie do outro; uma era na Itambé outra era na Maranhão; tinha 2 escolas, hoje quantas escolas tem na cidade de São Paulo?

Hev: Na cidade tem 14.

Zé Mário: Na cidade de São Paulo?

Hev: É. Guarulhos, na Grande São Paulo.

Zé Mário: Quer dizer ...

Hev: No estado de São Paulo tem 46.

Zé Mário: Então vai acabar ganhando pelo número de arquitetos que saem. 
Agora, eu acho que isso precisa mudar porque senão não adianta você ensinar a cotar ...

Hev: O senhor se formou, então, na FAU, né?

\section{Zé Mário: Em 72?}

E como que o senhor veio parar em São Carlos?

Zé Mário: É, eu vim dar aula. A Federal tinha um curso de arquitetura aqui que, para você ter idéia, quando eu cheguei, tinha mais arquitetos que engenheiros no curso de engenharia civil. Era um curso ligado à questão produção da habitação. E, eu vim para fazer mestrado e fiquei por aí...

Hev: Produção da construção ou habitação?

Zé Mário: Produção... era mais relacionado com habitação, era produção civil, um negócio assim, tanto é que o nome do curso era "produção civil", não era engenharia. Era ligado, realmente, à produção. Isso foi muito bom para mim, inclusive... para solidificar um pouco essa questão, porque eu acho que a arquitetura, você pode até dizer que arquitetura não seja construção, mas ... da construção ...

Hev: Não, eu sou dessa opinião ...

Zé Mário: O Zanettini, na última Projeto (ou AU?), fala umas coisas que têm na minha tese; e o Paulinho (Paulo Mendes da Rocha) fala uma coisa também interessante. Eu gosto muito do Paulinho ... "quem define as coisas na obra sou eu!" ... Tá certo! E ele falou agora um negócio interessante: toda idéia é de arquitetura, mas é construtiva. Isso é a possibilidade (...) Tudo bem? Mais alguma coisa? Não sei se eu te ajudei...
Hev: Ajudou sim.

Zé Mário: Agora, isso aqui, eu acho que não adianta ensinar tudo isso aqui se as outras disciplinas de projeto relacionadas a desenho ...

Hev: É... a gente não consegue ensinar tudo isso na aula. Então, seria uma leitura complementar.

Zé Mário: Mas, não adianta, se você conseguir ensinar tudo isso aqui em aula, se os outros ...

Hev: Ah! Sim... o mais importante são as outras coisas...

Zé Mário: Claro!

Hev: Acho que é isso!

Zé Mário: ok?

(Transcrição: Luciana Mascaro) 


\section{Entrevista com Marcelo Suzuki}

Arquiteto e Professor Marcelo

Suzuki

Data: 03.04.2003

Local: Sala 13 SAP EESC USP

São Carlos-SP

Hev: Prof. Marcelo Suzuki, viemos conversar com ovocê, pela importância como profissional arquiteto atuante e também como professor na área de projeto e desenho. Dentro do vasto campo de desenho de arquitetura, este questionário abordará somente questões relativas ao desenho técnico arquitetônico. Você se formou na FAU?

Suzuki: Na FAU, em 1980.

Hev: Naquela época, como era o ensino de desenho arquitetônico? Ou não havia a disciplina de desenho arquitetônico? Será que, historicamente, nunca houve?

Suzuki: Eu não sei dizer de muito tempo antes. Mas muito mais tempo antes, quando o Artigas estava na Poli, tinha. Eu não sei quem foi o responsável por achar que já era um fato consumado que os alunos aprendessem ao longo da projetação, a própria linguagem. Mas eu sei que há muito mais tempo atrás, ensinavam (desenho arquitetônico).

Hev: Sei. De fato, já acontecia isso já na sua época: de se aprender durante a disciplina de projeto.

Suzuki: Durante a disciplina de projeto. De se discutir o que está sendo representado ao longo da disciplina. O que foi mais importante, mas foi mais especificamente o caso da minha turma, foi as primeiras matérias de desenho de objeto, que na FAU tem e continua existindo como desenho industrial. No primeiro semestre do primeiro ano, em vez de projetar algum objeto, a gente fazia levantamento de objetos e tinha que desenhar...que eu acho interessante porque no desenho de objetos já constam detalhes que só vão aparecer provavelmente em arquitetura lá pelo terceiro ano ou nunca aparecem, que é a dificuldade que os alunos tem de detalhar.

Hev: Objeto mesmo?

Suzuki: Objeto mesmo. Prancheta, aquelas pranchetas reclináveis, com os parafusos ... Então, a gente fazia um levantamento de um objeto relativamente complexo; onde está a dobradiça... Isso era... passar para o papel como desenho técnico. 0 desenho industrial, ele demanda muito mais cortes parciais. Então, ... chamada detalhes e tal. De certa maneira é uma trombada que tomávamos, mas como o objeto é relativamente ágil no sentido de você voltar e tirar a medida de novo - ele está ali junto com você -, foi um aprendizado bem ... quase ... paralelo ao conteúdo da disciplina mas que acabou resultando muito bem.

Hev: E aí acabava ensinado as vistas... corte, vista, perspectiva.

Suzuki: É.

Hev: Isso era na seqüência de desenho industrial?

Suzuki: Desenho industrial. O projeto mesmo, o projeto arquitetônico, os professores já contavam que você soubesse, ou que você aprendesse ao longo do curso, os colegas...

Hev: Que se soubesse do curso técnico?

Suzuki: Não, não! Que viesse 
aprendendo no processo. E quase nunca se perdia muito tempo nisso, ensinando a desenhar. Então por exemplo, um projeto já seria muito mal atendido ou mal visto, se ele fosse mal desenhado, porque era um pressuposto que a gente já devia estar sabendo e fazendo.

Hev: Eu vi que você respondeu ... naquela pergunta (do questionário): "é necessário um novo manual de desenho arquitetônico, mais atualizado ...", ... você respondeu: não. Então, é mais uma dúvida minha: eu, como professor de desenho, em minha pesquisa, estou caminhando no sentido de que está precisando um manual mais atualizado. Eu não tenho ... eu queria ter essa visão, porque parece um paradoxo, os professores reclamam que os alunos não sabem desenhar, mas ao mesmo tempo não querem disponibilizar mais horas de ensino de desenho. Eu acabei ensinado desenho ..., desde quando eu entrei aqui (no SAP EESC USP), mas parece que não se ensinava. $E$ nem na $F A U$ não se ensinava ...

Suzuki: Na FAU não se ensina até hoje. Acho que entendi a pergunta de um jeito possivelmente dúbio, porque se se está precisando de um novo manual, eu não tinha entendido que estava havendo uma mudança do que está sendo representado. E como está sendo representado. Então, mesmo os desenho feitos no computador, o desenho é mais ou menos bonito, estou falando de desenho técnico: bonito, no sentido de bem apresentado, legível, claro etc., quanto foi na prancheta. Assim, foi nesse sentido que eu acho que não há uma mudança do que o manual ensinaria. Agora eu estou entendendo, que você está dizendo que o método para se chegar a esse desenho bonito, do ponto de vista técnico, deve ser pensado de novo ou deve ter um caminho novo, aí eu concordo. Se os manuais de desenho técnico que já existem buscavam chegar a este resultado que estamos falando ...

Hev: Seria desnecessário.

Suzuki: Seria desnecessário. Agora, enquanto método para se chegar a este campo que estamos falando ser infalível, então aí a gente está, sim, precisando. É o método para se chegar até lá e não a questão do resultado. 0 resultado que aquele manual propunha é o mesmo.

Hev: Antigamente, nas escolas de Belas Artes (...) ou, talvez, o próprio Artigas (ou antes dele), se desenhava muito ... tinha aquareladas, ... o desenho técnico mesmo, super preciso, isso tudo foi ... não digo que a gente tem que resgatar tudo isso aí ... Mas, até que ponto você acha que se deva desenhar desenho arquitetônico na escola? De um aluno que não teve curso técnico: ele vem, faz o primeiro ano ... e vai começando sua vida de formação de arquiteto ... Até que ponto tem que ensinar? Rapidamente, passar convenções ... como é o corte, como é que ... falar das vistas ortogonais e desenho técnico, ... aí, mostrar como que é a planta, o corte e só depois ... seria uma coisa que daria para de fazer em quatro meses e até menos ...

Suzuki: Diante da grade (curricular) que a gente tem em várias escolas que eu conheço, eu acho que deveria ser no máximo seis meses, mas eu não saberia fazer um plano desses seis meses, de um semestre letivo. Porém, as convenções e o por quê das convenções é absolutamente necessário. E ... treinar, dentro dos quatro meses ir transmitindo um pouco de ... visualização, um pouquinho de traquejo para eles. Eu sei que talvez seja pouco, mas grande parte dos alunos, depois de muito tempo convivendo ... 0 
traquejo mesmo vem é de escritório. Existe uma circunstância psicológica completamente diferente do aluno no atelier e do aluno no escritório. Sendo seu estagiário, mesmo não sendo seu aluno, mas ele sendo estudante. $\mathrm{E}$ essa diferença de postura, vale para tudo, até para um estagiário ser bom e ir continuando com a gente. Depois se forma, e fica nossos amigos e tal, ... e vai indo bem na profissão. E a gente torce por ele e tal. Em geral, eles no escritório já vão se imbuindo de questões muito ... muito ... mais rapidamente do que ele é capaz de fazer isso no atelier. Preocupando-se com prazo, com a precisão, com a quantidade de informações corretas ... rapidamente pega este clima no escritório ... No atelier, por mais que você repita e ensine de novo, no semestre seguinte, parece que, às vezes, esqueceu. ... Um pouco de que é necessário o trabalho de escritório para todos, pelo menos por parte da convivência entre a academia e os trabalhos fora.

Hev: Os escritórios acabavam ... formando também, em desenho arquitetônico.

Suzuki: Pois é. Não só em desenho arquitetônico, mas até em linguagem informatizada: o CAD, por exemplo. $E$ a velocidade com que eles acabam pegando traquejo, por estar operando no escritório e não na escola, ... assim como no nosso tempo: nanquim e acabamento, cruzamento de linha etc., ... pegava isso no escritório e não na escola. Eu me lembro que a preocupação, no escritório, era de nos esmerarmos e de deixar um desenho tal que fosse elogiado pelo chefe ... era sempre muito maior do que na escola.

Hev: Certo.

Suzuki: Sempre mesmo. Na escola, o aluno se conforma um pouco, também, com aquilo que a a gente chama de tempo para pensar e, no escritório, você acaba sendo obrigado, acaba se acostumando com o prazo pré-estabelecido, não é o tempo para pensar, é o tempo para fazer. Isso diferencia muito a escola da realidade, no bom sentido, ... Acho que muitas discussões sobre conteúdo, sobre ... a qualidade da arquitetura pensada ... é uma cobrança maior do que todas as outras. Então, é prioritário que, se você não fez essa maquete muito bem, mas o conteúdo de arquitetura proposto nessa maquete está ótimo, ... Essa maquete não foi feita para ser apresentada, mas foi feita como um processo do seu pensamento, do seu saber construído. Então, a maquete é um "favelão", mas o projeto é bom. Com aquele alerta: na realidade, você vai apresentar para um cliente, ... leva uma maquete bem feita. Então, tudo bem o seu projeto, leve um desenho bem feito. Treine croqui, aprenda a fazer croquis na frente do seu cliente; ele se emociona quando vê isso, que você sabe. Às vezes, a gente pega uns traquejos assim ao longo da vida, que viram até truque. Por exemplo, desenhar a perspectiva explicativa de um assunto que você está conversado com o cliente, ... e a perspectiva o tempo inteiro sendo desenhada na frente do cliente. Aí você o vê ficando embasbacado. Primeiro, porque entendeu; segundo, porque vai te respeitar um pouco mais ... Você se desenvolve. Por isso, esse desenvolvimento tem que existir também. É uma contradição, esses conteúdos todos ... são importantes. Mas, realmente, esse conforto de usar (desenhar) com fluência, eu acredito que só surge mesmo depois que a gente se faz profissionalmente.

Hev: A minha pesquisa, acho, que está caminhando em até que ponto tem que ensinar o desenho. E eu sei que cada vez mais está sendo absorvida as horas de aula com outros saberes, e que o desenho está 
ficando reduzido a quase um ano ou seis meses, daqui a pouco vão até tirar ... Tem escola que já não tem, pedem para os alunos fazerem curso na escola como se fazem Word, Excel na cidade (no mercdo), ... e esta caminhando para que eu proponha um manual que seja uma leitura complementar, atualizado, para que os alunos tenham um manual ... Bom, talvez, algumas perguntas ficam inválidas com as explicações que você fez ... Tenho reparado que, atualmente, os alunos ou arquitetos recém-formados, na grande maioria, não sabem desenhar como antigamente, tanto desenho expressivo como desenho técnico. De fato isso aconteceu: no meu tempo de graduação, a gente ficava vendo perspectivas dos alunos mais velhos, hoje não tem tanto isso ...

Suzuki: É verdade. E ... tem exceções. $E$, quando tem a exceção, você fica sabendo e tal, fulano ... Agora, o que está acontecendo muito é a especialização nisso. Por exemplo, eu não tenho nem pensado nem cogitado de participar mais de concurso. Um dos grandes motivos é a apresentação: os grandes escritórios estão contratando um escritório a parte para formular a apresentação ...

Hev: Uma profissionalização da apresentação.

Suzuki: É, exatamente. Então, é um escritório de acabamento ... de idéias, para formular a apresentação para alguns concursos. Fiquei sabendo de uns escritórios que gastaram muito dinheiro nos concursos, coisa de vinte paus, para pegar, sei lá, terceiro lugar, quarto lugar ... Isso porque, no caso, esse que pegou o terceiro lugar é uma pessoa conhecida de um amigo, ... eu sei que gastaram vinte paus. E soube que os que ficaram em segundo e primeiro gastaram muito mais. Eu sei de escritórios que estão mantendo equipes dentro do escritório, a parte, só para concursos; e dentro desta equipe, uma turma só para apresentação. Então ... sei desses meninos formados na FAU que são só maquetistas, como o Kenji, que sempre foi maquetista, sobrevive disso. Os escritórios que estão sempre se especializando em 3D Stúdio ... essa coisa dos grandes desenharem muito bem já valiam, ... já valia faz tempo, por exemplo, o Vallandro (Keating) sempre sobreviveu só de ...

Hev: Perspectivas.

Suzuki: Vender perspectivas. Tem outros, além dele. Essa é uma exceção do expoente, ... virtuose do desenho, seja no computador, seja a mão, que acabam, então, se especializando, ... virando um especialista. 0 desenho, o traço característico de arquiteto ... vai demorar para surgir, mas em geral surge junto com a obra, quando ele começa a fazer um certo sucesso, ... e começa a publicar croquis ... 0 pessoal que desenha bem com o computador está aí na praça agora, ... fazendo representações bonitas; algumas até com certo exagero de recursos, ... já que tem o recurso, usa; já que tem o outro recurso, usa também. Isso acaba virando um pouco de salada de recursos. Mas tem ... tem ... isso acho que está por aí, sim.

Hev: Outra questão: Atualmente, existem aproximadamente 150 escolas de arquitetura no país, 46 no Estado de São Paulo, 14 na cidade ... na Grande São Paulo. Ouvimos dizer que algumas faculdades de arquitetura atendem o currículo mínimo estabelecido pelo MEC, que é de 3500 horas e já que não têm a disciplina de desenho arquitetônico. $E$ sugerem que os alunos façam o curso fora da escola, o que acha disso? Em minas Gerais algumas escolas já não tem ... 
Suzuki: É, tem algumas em São Paulo também fazendo isso. Algumas, ... as particulares tem essse curso dentro da escola, mas cobra a parte. É como se fosse um curso extra, assim como se eu resolvesse fazer inglês. Eu não preciso ir lá no centro da cidade, mas se essa escola tivesse inglês e também fosse outro curso pago, eu pagasse a parte ...

Hev: Certo. Nas particulares vale tudo!

Suzuki: É ... Bom, faz parte do mesmo problema, enquanto nós estamos pensando que o desenho arquitetônico é importante para todos, ou seja essa batalha tinha que ser via MEC, ou seja aumentar a carga horária mínima e incluir nesta carga horária, o curso de desenho, nem que seja de quatro meses.

Hev: Certo.

Suzuki: Ah! Mogi tem, as escolas da cidade tem ... aqui tem ... é eu sei por aí que tem essas que ... CAD, por exemplo, é pago a parte etc.

Hev: Sei.

Suzuki: É complicado ... eu acho que, se não entrar no currículo mínimo, eles não vão (voltar atrás).

Hev: Certo ... O Gastão ... O Gastão, não. O Zé Mário me falou: "a tua pesquisa é legal, mas, o que importa é ensinar os alunos a serem arquitetos, ... pensarem como arquitetos, proporem ... desenho é convenção, aprende-se depois até ...". Ele não falou isso mas ...

Suzuki: É, ele é partidário dessa ... aprender no projeto ...

Hev: É, e que vão aprender em seis meses na vida profissional, isso é ... não é tão importante. Não sei se é porque eu vim da Federal de
Curitiba, em que tive (realmente) aulas de desenho, ou porque eu trabalhei muito com desenho ... e que eu achei importante ... até insisto, exaustivamente, com os alunos, ... estou até revendo, agora - com o Prof. David me ajudando -, a ver mais o desenho expressivo, e fazer, ... e dar mais uma visão mais geral do desenho técnico arquitetônico, ... e não ficar exigindo que os alunos façam (desenho) "executivo", no primeiro ano.

Suzuki: É, eu sempre achei que desenhar bem faz parte da profissão. Sempre.

Hev: Até como professor de projeto.

Suzuki: Inclusive, acho muito capricho meu. Ter esse tempo ... desenhando, esmerando-se, fazendo, porque, ... enquanto você está desenhando, você está pensando. Então, às vezes você esta desenhando, sei lá, o revestimento de uma parede que ela ... essa parede, desenhando a diferenciação de osso e revestimento de uma parede que ela está discutível no projeto ainda ... Mas, eu gosto de ver ela bem feitinha, toda caprichadinha primeiro e depois rediscutir a existência dela ou não. Mas, aí também, não sei se para todo mundo é assim ... enquanto processo, ... mas, eu sempre brinco com os alunos e... quando vão chegando no quarto e quinto ano, ... colorir mapa por conta de um plano de massa, plano urbanístico, ... enquanto você está colorindo você está pensando, ... não é perda de tempo nenhum ..., depois que você vê aquela mancha pronta, a mancha sobreposta ao mapa já quer nos dizer outra coisa, aquele código é aquela mancha cor de laranja, e outra mancha é verde ..., elas estão falando coisas para você. Então, esse tempo é necessário. Claro que, a medida que você vai ficando mais experiente, alguém pode fazer 
para você; e você, batendo o olho, já ter conclusões rápidas e tal. Mas isto vem da experiência enquanto vai treinando, vai desenhando também. Eu ... dei umas "duras" aí em TGI, com uma frase que eu acho engraçada, porque os alunos ficam surpresos: até hoje, TGI, quinto ano, ainda não "caiu a ficha" que, planta é um corte deitado e corte é uma planta em pé. Se não caiu essa ficha ainda, eles (os alunos) tomam um susto. Não pensaram nisso. E é verdade, ... tanto faz ... Se o mundo virar de ponta cabeça, se o mundo virar 90 graus, ... e se nós fôssemos capazes de usar a tridimensionalidade como um espaço tátil, ... e não só o que está contido nele, tanto faz ... mesmo se a gente elevasse uma parede fizesse uma planta ... a planta é a parede.

Hev: É a mesma coisa.

Suzuki: Mas, essa frase assim, toda vez que eu tenho repetido, ... tem tocado em gente que não tinha pensado nisso.

Hev: Como que é trabalhar com a Lina (Bo Bardi)... porque ela ia muito ... ela montava o escritório no canteiro, ficava muito presente ... saia projeto executivo de arquitetura?

Suzuki: Saia também ... O processo lá era o seguinte: ela ficava no canteiro fazendo croqui de todas as situações convividas lá no canteiro e o que que nós íamos propor de efeito. E a partir dos croquis dela, que em geral era aquarela ... ela usava tudo, caneta Bic, qualquer papel, ela fazia esse croqui e eu guardava numa pasta e a gente ia incluindo isso no projeto executivo feito lá, junto. E...

Hev: Vocês também ficavam lá no canteiro trabalhando na prancheta

$$
\text { ... }
$$

Suzuki: Com ela ... Então, a gente ia traduzindo os seus desenhos em desenho executivo. Isso até para oficializar a entrega formal e tudo mais ... Agora ... em geral os desenhos dela eram livres, mas muito complexos, tinham as especificações as chamadas ... todo coloridinho e tal, então ficava muito claro. E essa passagem para o executivo estava ali, tudo que ela estava querendo estava possível já ... digamos assim de passar a limpo, não era passar a limpo aquele desenho, era transformar aquele croqui em planta, corte, especificação e tal, mas era assim.

Hev: E vocês estavam desenhando na prancheta ... no canteiro.

Suzuki: No canteiro ... a gente ia para lá cedinho ... Em geral, chegava de manhã já com muita tarefa que era passar para o papel os desenhos que ela já tinha deixado. $\mathrm{E}$, depois, a gente fazia uma segunda etapa, que era andar pelo canteiro, conversar com todos os trabalhadores; ver o que todo mundo estava fazendo etc. Dessa rodada saia uma nova leva de croquis. Aí, íamos embora. Chegava o dia seguinte, já redesenhava tudo.

Hev: Interessante. Eu queria mostrar o terceiro capítulo ... mudou agora, ... na verdade o meu trabalho não vai mais ser isso: propor subsídios para montar um manual de cotas, só cotas, um índice de desenhos técnicos. Mas, agora, a banca, com o professores Hugo e Jairo, caminhou para a constatação do ensino de desenho arquitetônico nas escolas ... [mostra alguns desenhos]

Suzuki: Tem (no Cedoc SAP) um pacotão ... de vários projetos executivos, tem um do Kurokawa ...

Hev: Eu já vi, uma cópia heliográfica grande, sei ... Aqui é um vocabulário de elementos de cotas ... o que pode fazer e o que não pode. 0 Hugo achou isso muito confuso, 
porque ... se fosse um manual, ... e que as letras sempre tem o mesmo tamanho independente da escala, ... a altura das letras, ... ela não varia. $E$ aqui ... isso é uma coisa que eu considero que o aluno não sabe, que eu destrinchei em três níveis, que são os acidentes da parede, as aberturas; outro seria as distâncias e as espessuras; e outro seria a silhueta externa da construção que, junto, ficaria isto ... que, na prática, às vezes, é melhor fazer dentro, ... A norma fala que tem que fazer for a, na medida em que não for possível, ... passa para dentro. ... Já o prof. Jairo falou destas cotas funcionais, que eu abordo mais à frente, ... e tirar essa. Então, já tira porque ... para evitar erro de construção, ... então, já deixa sem (omite-se).

Suzuki: A gente tem em restauração ... obras existentes, que a gente precisa fazer o seguinte: eu pego duas, três, quatro, ... e quando chegar na última, que eu sei que o erro deve ter acumulado, ... ali, eu ponho um "R" que é resultante. Então, ... um, dois ... resultante; um, dois ... resultante; às vezes, inverte. Depende, se no meu critério em relação ao que existe lá, eu acho mais importante, eu coloco "errezinho" mesmo, eu edito a cópia e ponho "R" e aí aviso que "R" é a resultante. Ou seja, eu quero que eles privilegiem aquela direção.

Hev: Depois, este aqui é um (desenho) executivo desenhado por nós e ... falei que, na prática, fica cheio de poluição de informação, ... às vezes, as cotas que deviam ficar lá fora, onde passa uma canaleta, acaba passando dentro.

Suzuki: Quando aparecem áreas hidráulicas, aumenta muito a poluição. 0 que a gente costumava fazer também é colocar um hatch (hachura) cinza, ... hatch cinza é ampliação, não é detalhe. Então, primeiro ampliação número 1; aí dentro da ampliação tem detalhe 1 , detalhe 2, ... ampliação 1, ampliação 2. E a mancha cinza já é o seguinte: aqui (as cotas) não tem tanta importância assim ... só as gerais, e lá você vai procurar no outro (na ampliação), ... aí vai em outro, o desenho fica mais limpo ...

Hev: Aqui é amarração ... A locação de obra, que vai ser a partir desse ponto, ... nesse caso, como fica ...

Suzuki: Como você está fazendo o "certo-e-errado", tem aquelas malditas cotas que às vezes aparecem, de estagiário ..., que é assim ...

Hev: Sim, exatamente. Que não está cotando nada.

Suzuki: Por eixos ...

Hev: Por eixos... E aqui, esta foto ... é o gabarito indicando os fios de amarração ... E que num desenho não vale a pena fazer num desenho muito grande (folhas grandes), que na obra fica tudo rasurado.

Suzuki: É, ... então, você podia, nesse caso de desenho grande, fazer desenho com mapa de localização também ... aí, você faz uma legenda, de que você está do lado esquerdo, e a folha com ... vai estar do lado direito. $\mathrm{Ou}$, a folha $1 \mathrm{a}, 1 \mathrm{~b}$; e depois, em outras áreas, $2 a, 2 b$... dividir $a$ planta em dois ...

Hev: Aqui é o vocabulário das cotas radiais ... Aqui é um pouco aquilo que você uma vez me mostrou em uns desenhos ... Isso que eu acho que era uma coisa que, no colégio, deviam ensinar, e nós é que estamos assumindo essas coisas de geometria, ... que estão aprendendo muito mal no colégio, ... as concordâncias, ... Aqui é uma parede curva num terceiro andar, que durante o projeto a gente tinha a materialização de um ponto, 
com um raio, a sua localização. Mas, no momento de construir, ... é outra coisa, ... um gabarito no chão, ... e aqui, essa cota é importante para medir o comprimento do rodapé, ou multiplicar pela altura e ver quanto vai de massa. À hora de construir, porém, tem que dar essas medidas assim. ... Aqui são as setas, 0 indicador de setas, ... nome técnico de indicador, ... já vi fazer um pouco inclinado para não competir com a verticalidade do desenho. Aqui ... eu venho cotando peças hidráulicas na parede e aí, empolgado, acabo cotando alguma coisa que está no chão, ... estão em planos diferentes. Portanto, tem que ser cotado separado. Aqui, para o arquiteto, ... para ele interessa essa medida e, para o calculista ou fabricante, a que vai até a fundação, ... estamos falando de uma mesma coisa. E aqui, as cotas funcionais, por exemplo, o certo seria cotar pelo eixo, ... aqui, mas para eu garantir que tenha quatro centímetros, ... cotar por aqui, ... se por acaso não acharem a bitola correta ele vai colocar uma mais grossa e vai prejudicar a ..., se bem que, quem vai montar, tem que ir confiante para passar as coisas.

Suzuki: Às vezes não tem não; é melhor cotar assim mesmo.

Hev: Ou ter que aumentar a grapa (do suporte de fixação do corrimão da escada).

Suzuki: É.

Hev: Este é um caso, ... até eu contei isso na qualificação, de que... daquele caso de eliminar esta cota porque, ... essa pedra (bancada) é importada e eu já encomendei. Aí, em vez de ter dado $3.00 \mathrm{~m}$ deu 2.90, ... quando eu tiro a liberdade de vir para cá, para evitar de prejudicar a peça, que poderia entrar em atrito com a guarnição da porta.
Suzuki: É. Você tira de um lado e do outro, pode ser a resultante ...

Hev: Aqui, também, eu estava escrevendo que, enquanto estava em fase de projeto, a gente não sabia a altura desta viga. Então, que se cote somente até embaixo da viga, e que o prédio "cresça" para cima, para não comprometer o pé direito do projeto ... Aqui, recomendando que não se cote a espessura da laje, mas de piso acabado a piso acabado.

[acabou a fita]

(Transcrição: Nilton César Nardelli) 